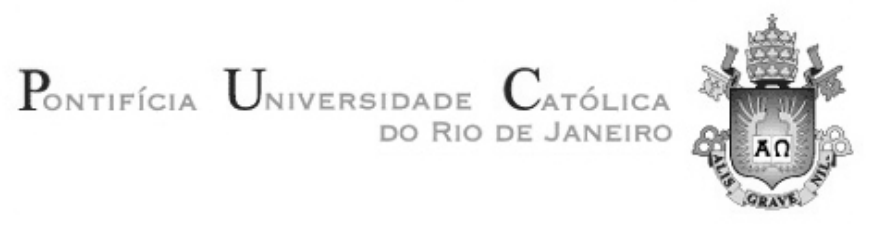

Vanessa da Silva Figueiredo

\title{
A Microcelebridade em sua Corte: Legitimidade e Discurso no Circuito-Cardoso
}

Dissertação de Mestrado

Dissertação apresentada como requisito parcial para obtenção do grau de Mestre pelo Programa de PósGraduação em Comunicação Social do Departamento de Comunicação Social da PUC-Rio.

Orientadora: Profa. Adriana Andrade Braga

Rio de Janeiro

Março de 2013 


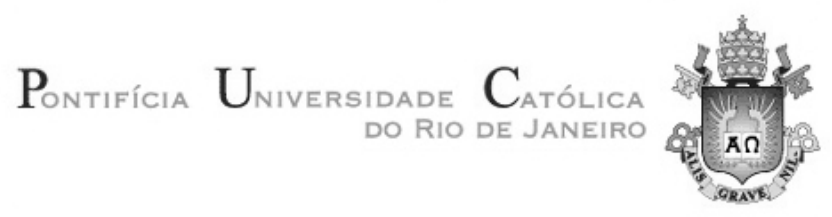

Vanessa da Silva Figueiredo

\author{
A Microcelebridade em sua Corte: \\ Legitimidade e Discurso no Circuito-Cardoso
}

Dissertação apresentada como requisito parcial para obtenção do grau de Mestre pelo Programa de PósGraduação em Comunicação Social do Departamento de Comunicação Social do Centro de Ciências Sociais da PUC-Rio. Aprovada pela Comissão Examinadora abaixo assinada.

Profa. Adriana Andrade Braga

Orientadora

Departamento de Comunicação Social - PUC-Rio

Profa. Cláudia da Silva Pereira

Departamento de Comunicação Social - PUC-Rio

Profa. Simone Maria Andrade Pereira de Sá

UFF

Profa. Mônica Herz

Coordenadora Setorial do Centro de Ciências Sociais - PUC-Rio

Rio de Janeiro, 11 de Março de 2013 
Todos os direitos reservados. É proibida a reprodução total ou parcial do trabalho sem autorização da universidade, da autora e da orientadora.

\section{Vanessa da Silva Figueiredo}

Graduou-se em Produção Cultural pela Universidade Federal Fluminense em 2007. Participou do grupo de pesquisa em Políticas Culturais do CNPq entre os anos de 2006 e 2007. Bolsista da Coordenação de Aperfeiçoamento de Pessoal de Nível Superior (CAPES) durante o curso de mestrado. Atuamente é especialista em redes sociais e interações em ambientes digitais.

Ficha Catalográfica

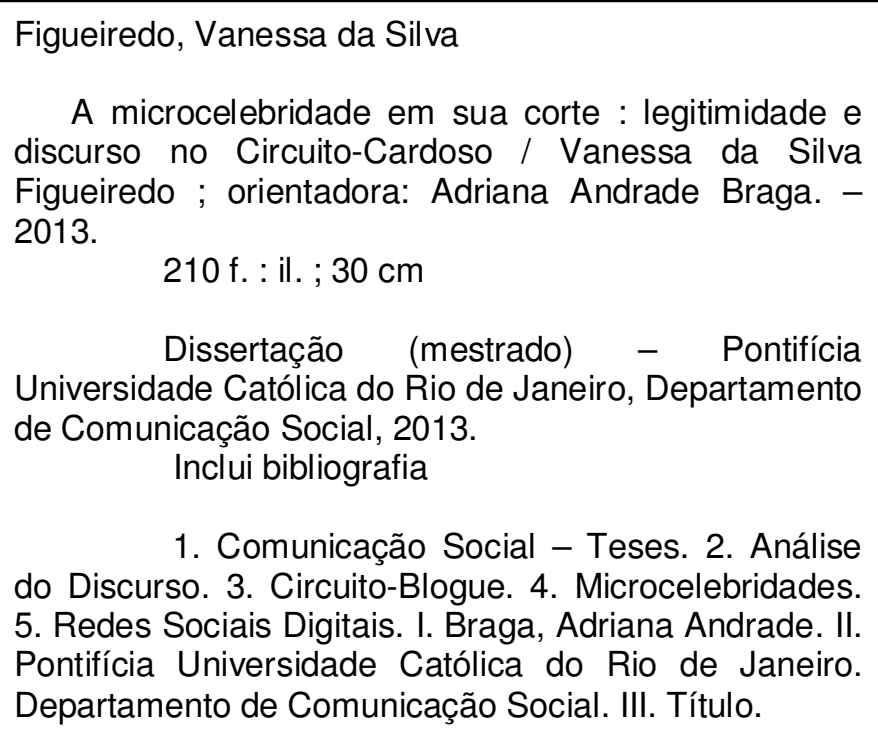

1. Comunicação Social - Teses. 2. Análise do Discurso. 3. Circuito-Blogue. 4. Microcelebridades. 5. Redes Sociais Digitais. I. Braga, Adriana Andrade. II. Pontifícia Universidade Católica do Rio de Janeiro. Departamento de Comunicação Social. III. Título.

CDD: 302.23 


\section{Agradecimentos}

De fato, muitas pessoas colaboraram para que esta pesquisa fosse realizada e, principalmente, para que eu chegasse até aqui. Meus pais, minha sogra, meu marido e amigos e amigas me incentivaram de alguma forma para que de uma pequena ideia surgisse um trabalho como esse. Agradeço a todos e a todas que estiveram ao meu lado, nos bons e nem tão bons momentos dessa longa jornada.

Ainda, é preciso agradecer aqueles e aquelas que me ajudaram diretamente com orientações, ideias, dicas, sugestões e tudo o que houvesse direito.

À minha orientadora, Adriana Braga, pelas sugestões, pelo incentivo e pela inspiração para que essa pesquisa chegasse aonde chegou.

À CAPES e à PUC-Rio, pelos auxílios que possibilitaram a realização desta pesquisa.

Às minhas amigas Ana Paula Goulart de Andrade e Theane Sampaio, pelas sugestões, pelas dicas, pelos vários papos criativos e por toda compreensão.

Às professoras Simone Pereira e Cláudia Pereira, por terem aceito o convite e participarem da banca examinadora.

À Marise Lira, por toda paciência, ajuda e compreensão.

Aos(às) meus(minhas) colegas da PUC-Rio.

Aos(às) professores(as) do Departamento, pela ajuda e pelos ensinamentos.

$\mathrm{A}(\grave{\mathrm{A}})$ todos(as) aqueles(as) que me ajudaram chegar até aqui. 


\section{Resumo}

Figueiredo, Vanessa da Silva; Braga, Adriana Andrade. A Microcelebridade em sua Corte: Legitimidade e Discurso no CircuitoCardoso. Rio de Janeiro, 2013. 210p. Dissertação de Mestrado Departamento de Comunicação, Pontifícia Universidade Católica do Rio de Janeiro.

A fama conquistada por indivíduos através de ambientes digitais resulta de performances realizadas nesses espaços, por essa razão essas pessoas são denominadas "microcelebridades". Trocas de links, visitas e comentários de retribuição em blogs são alguns dos fatores que contribuem para a conquista dessa visibilidade, constituindo o que Adriana Braga (2008a) denominou "circuitoblogue", reiterando o papel de destaque desempenhado nesses ambientes. Esta pesquisa consiste em um estudo sobre as seções de comentários do Blog do Cardoso, do Contraditorium e do MeioBit, blogs pertencentes ao blogueiro Carlos Cardoso, com o objetivo de observar as práticas sociais ocorridas nestes espaços, bem como a legitimação de uma hierarquia simbólica, entre comentaristas e Carlos Cardoso, sob a ótica da Análise do Discurso. A partir dessa análise foram destacados aspectos da apresentação do self, da formação de uma "corte" em torno do blogueiro, das estratégias discursivas de legitimação de hierarquias e das disputas internas por essa legitimação.

\section{Palavras-Chave}

Análise do discurso; circuito-blogue; microcelebridade; redes sociais digitais. 


\section{Abstract}

Figueiredo, Vanessa da Silva; Braga, Adriana Andrade (Advisor). Microcelebrity in his court: Legitimacy and Discourse at CardosoCircuit. Rio de Janeiro, 2013. 210 p. MSc Dissertation - Departamento de Comunicação Social, Pontifícia Universidade Católica do Rio de Janeiro.

Fame obtained by individuals through digital environments is acquired by actions performed in those places, for this reason those people are named "microcelebrities". Link exchanges, visits and comments on blogs play a part to get visibility, composing what Adriana Braga (2008a) called "blog-circuit", reaffirming the featured role played in those environments. This research consist in examine comment sections of three blogs of Carlos Cardoso: Blog do Cardoso, Contraditorium and MeioBit, aiming to observe social practices in those places, such as the authenticity of a symbolic hierarchy between commenters and Carlos Cardoso, under the Discourse Analysis perspective. This analysis highlighted elements of presentation of the self, of the emerging "court" around the blogger, of discursive strategies on hierarchies' legitimacy and intern rivalry to claim that legitimacy.

\section{Keywords}

Discourse analysis; blog-circuit; microcelebrity; digital social networks. 


\section{Sumário}

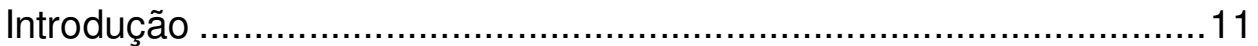

1. De Anônimo a Microcelebridade: Web 2.0 e participação

1.1. Fama e Reconhecimento: a noção de celebridade ...................16

1.2. Web 2.0 e Participação .........................................................28

1.3. Carlos Cardoso, seus blogs e a cultura geek.........................34

2 Comunicação, Mediatização e Interação

2.1. Mediação e Mediatização no Circuito-Cardoso ........................44

2.2. Os Percursos da Microcelebridade ..........................................55

3. Metodologia

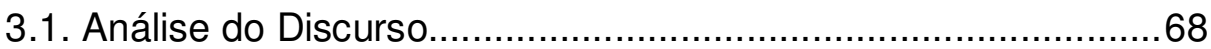

3.2. Natureza dos Dados.......................................................... 79

3.3. Procedimentos Analíticos ....................................................92

4 O Circuito-Cardoso: aspectos analíticos

4.1. O Eu e os Outros...............................................................95

4.2. A Corte de Cardoso: valores e hierarquias ...........................118

4.3. Experiências e Estratégias: domínio das linguagens ..............147

4.4. Quem é Quem: disputas por legitimação ..............................167

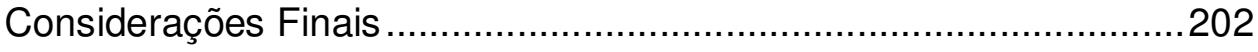

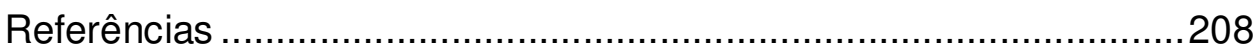




\section{Lista de Gráficos}

Gráfico 1 - Comentários/Post 2005 Blog do Cardoso 79

Gráfico 2 - Comentários/Post 2006 Blog do Cardoso 79

Gráfico 3 - Comentários/Post 2007 Blog do Cardoso 80

Gráfico 4 - Comentários/Post 2008 Blog do Cardoso 80

Gráfico 5 - Comentários/Post 2009 Blog do Cardoso 80

Gráfico 6 - Comentários/Post 2010 Blog do Cardoso 81

Gráfico 7 - Comentários/Post 2011 Blog do Cardoso 81

Gráfico 8 - Comentários/Post 2006 Contraditorium 81

Gráfico 9 - Comentários/Post 2007 Contraditorium 82

Gráfico 10 - Comentários/Post 2008 Contraditorium 82

Gráfico 11 - Comentários/Post 2009 Contraditorium 82

Gráfico 12 - Comentários/Post 2010 Contraditorium 83

Gráfico 13 - Comentários/Post 2011 Contraditorium 83

Gráfico 14 - Comentários/Post 2006 MeioBit 83

Gráfico 15 - Comentários/Post 2007 MeioBit 84

Gráfico 16 - Comentários/Post 2008 MeioBit 84

Gráfico 17 - Comentários/Post 2009 MeioBit 84

Gráfico 18 - Comentários/Post 2010 MeioBit 85

Gráfico 19 - Comentários/Post 2011 MeioBit 85 
Eu, um pesquisador? Oh, não empregueis tal palavra!... Sou apenas muito pesado, de muitos quilos! Caio, caio sem descanso, Para chegar, finalmente, ao fundo! Friedrich Nietzsche, A Gaia Ciência 


\section{Introdução}

Uma pessoa que cria e mantém um blog pode obter visibilidade somente por sua performance em ambientes digitais? A composição de sua personalidade online depende, além de si mesmo(a), de seus(suas) seguidores(as), de seus pares e de seus críticos? Essas são algumas questões que nortearam a presente pesquisa. Carlos Cardoso é um blogueiro que se tornou conhecido por sua performance em blogs e páginas de sites de redes sociais, nos quais publica posts que abordam, em grande parte, temas caros à cultura geek. A sua persona digital foi composta, gradualmente, por meio de trocas de links, visitas e comentários em blogs e páginas de redes sociais de outros(as) blogueiros(as) populares e do reconhecimento daqueles(as) que acompanhavam as suas produções nesses espaços.

As seções de comentários do Blog do Cardoso, do Contraditorium e do MeioBit - blogs em que Carlos Cardoso publica posts - apresentam um cenário interessante para observarmos a emergência da popularidade de blogueiros(as) em ambientes digitais. Cardoso, como é conhecido na blogosfera, conquistou um público interessado em acompanhar suas performances nesses espaços, assim como obteve respeito e reconhecimento de outras microcelebridades, dois dos principais determinantes de seu sucesso on-line.

Querer ser lido e fazer sucesso com suas páginas pessoais parecem ter sido alguns dos motivadores para que Cardoso conquistasse visibilidade na Web. Tais elementos podem ser observados em sua performance, construída com base em interações e na publicação de posts nos blogs em análise. O interessante, nesse contexto, é a demonstração dada pelo blogueiro de seu conhecimento e dos artifícios usados para que seus blogs e seus perfis em sites de redes sociais conquistassem seguidores(as) interessados em sua persona digital. Ou seja, estar a par da dinâmica de trocas de links, elogios e críticas, do funcionamento dos mecanismos de sites de busca, por exemplo, parece constituir uma vantagem para se destacar entre os pares e diante de seguidores(as). 
O reconhecimento conquistado na blogosfera fundamentou, portanto, a ascensão de Carlos Cardoso como microcelebridade e, consequentemente, garantiu popularidade ao blogueiro. Cabe ressaltar que essa visibilidade encontrase limitada por um circuito de trocas e de interações formado em torno de Cardoso. Tal circuito é denominado "circuito-blogue” (BRAGA, A., 2008a).

Diante desse cenário, torna-se pertinente nos debruçarmos sobre as práticas sociais existentes nesses blogs, a fim de que possamos descrever elementos da composição da persona digital de Cardoso e da participação dos comentaristas na legitimação dessa persona. O uso de técnicas para atrair visitantes e estimular comentários também serão observados, especialmente pelo fato de que são capazes de reunir comentaristas habituais, outras microcelebridades e forasteiros(as) no âmbito das seções de comentários dos blogs analisados.

Os(as) comentaristas de Cardoso interferem na construção de sua personalidade e, assim, contribuem para a visibilidade do blogueiro nos ambientes digitais. Os grupos de comentaristas possuem, cada qual, uma visão particular de Carlos Cardoso: uma parte legitima as opiniões e o comportamento do blogueiro; outra parte repudia seus posicionamentos. Por essa razão, é de suma importância descrever como aspectos aparentemente opostos acabam colaborando para o surgimento de uma figura considerada popular na blogosfera por sua performance, como acontece no caso de Cardoso.

Os objetivos do presente trabalho são identificar e descrever processos de reconhecimento entre comentaristas dos blogs de Carlos Cardoso, bem como caracterizar a composição da persona que transforma o blogueiro em microcelebridade (BRAGA, A., 2008a). Igualmente, pretendemos observar as práticas socais existentes nas seções de comentários do Blog do Cardoso, do Contraditorium e do MeioBit, como caracterizadoras de performances e interações caros ao grupo. Tendo como referência a Análise do Discurso - Michel Foucault (2010) e Dominique Maingueneau (1997; 2004) -, pretendemos reconhecer elementos no comportamento de Cardoso, refletidos em comentários, que o legitimam como figura de destaque entre o grupo participante das interações nesses ambientes.

Para o desenvolvimento dessa pesquisa, partimos dos seguintes objetivos específicos: 
- Identificar elementos usados por Carlos Cardoso na composição de sua persona digital;

- Verificar como a persona digital do blogueiro é legitimada por aqueles(as) que comentam no Blog do Cardoso, no Contraditorium e no MeioBit;

- Identificar artifícios usados para a divulgação dos blogs e para chamar a atenção de potenciais comentaristas;

- Identificar códigos, protocolos e linguagens usados nesses espaços;

- Acompanhar a legitimidade de Cardoso, como microcelebridade, por meio das interações entre seus(suas) comentaristas, microcelebridades e da relação com as mídias;

- Investigar a composição do circuito comunicacional formando em torno de Carlos Cardoso.

Carlos Cardoso possui uma performance peculiar nos ambientes digitais em que atua. Essa característica é observada nos estilos usados para elaborar posts: apelo constante a referências ligadas a seriados televisivos, filmes, acontecimentos históricos, jargões da área de tecnologia; uso de técnicas para aumentar o número de visitantes; posts "pegadinha", em que o blogueiro induz o(a) leitor(a) a acreditar em ideias que, ao final, não passam de uma brincadeira. Por esse motivo, o blogueiro atrai, na mesma proporção, fãs e detratores(as).

Antes mesmo de pensar nessa pesquisa, acompanhei muitos posts de Cardoso e, ao longo do tempo, acabei me tornando uma de suas seguidoras. Inicialmente foi preciso me familiarizar com a linguagem e com o estilo do blogueiro expressar suas opiniões. Nas seções de comentários de seus blogs nos deparamos com debates e discussões inflamadas entre comentaristas, revelando diversos pontos de vista sobre o que foi abordado por Cardoso em seus posts. Por essa razão, até hoje não tive coragem de fazer um comentário nesses espaços. No Blog do Cardoso, no Contraditorium e no MeioBit encontramos opiniões claramente parciais de Cardoso sobre temas que vão desde atualidades, passando por conhecimentos gerais e, principalmente, sobre cultura geek. Por essa razão, nos defrontamos com muitos "artigos", como o próprio blogueiro fez questão de afirmar em um de seus posts, sobre assuntos ligados às áreas de informática e de 
tecnologia da informação. Para ilustrar as razões pelas quais Cardoso afirma escrever artigos em vez de posts, segue um trecho escrito pelo blogueiro:

"Post é o Cacete, eu escrevo artigos", publicado no Contraditorium em16/07/2006 Blog é Blog, usar "diário eletrônico" para não usar o termo novo é besteira. Blogar já virou verbo informal. Excelente. Só que eu blogo um texto, uma notícia, um artigo, uma nota. Não (grifo do blogueiro)um post. Aliás, eu posso até postar (grifo do blogueiro) algo, mas não um post. Post é genérico de "bloquinho de texto que não tenho saco de classificar".

Podemos perceber a preocupação de Cardoso de destacar-se dos(as) demais blogueiros(as), tendo em vista que explica a diferença entre "post" e "artigo". Portanto, existe a intenção, por parte do blogueiro, de reforçar a qualidade daquilo que publica e, mais importante, a sua preocupação de manter uma postura profissional para seus blogs.

Artigos ou posts, a verdade é que a popularidade de Cardoso é confirmada pela quantidade de visitações e de comentários que recebe em seus blogs e nas páginas de sites de redes sociais que gerencia.

Em meio ao volume de dados encontrados no Blog do Cardoso, no Contraditorium e no MeioBit, foi preciso determinar a relevância de empreender uma pesquisa com essas informações. Nesse sentido, é interessante ressaltar a importância de se estudar práticas sociais em ambientes digitais. Com base na observação realizada, podemos dizer que performances on-line dependem de uma série de fatores legitimadores, os quais derrubam o aspecto aparentemente democrático da Web. Com a finalidade de contribuir para o campo teórico e prático da Comunicação Social, precisamos demonstrar a interdependência existente entre figuras de destaque em ambientes digitais - microcelebridades - e das suas eventuais audiências, fornecendo aspectos próximos da realidade analisada nas seções de comentários do Blog do Cardoso, do Contraditorium e do MeioBit. Por isso, o estudo apresentado revela uma possibilidade para que se possa compreender um pouco mais sobre comportamentos, performances e práticas sociais entre os(as) usuários da Web.

A escolha dos blogs a serem analisados pela presente pesquisa foi feita com base na relação entre a quantidade de comentários e de posts encontrados nesses espaços. Portanto, observamos uma relação maior entre comentários/post ${ }^{l}$ no Blog

\footnotetext{
${ }^{1}$ Comentários por post: quociente do número total de comentários em um mês pelo número total de posts naquele mesmo mês.
} 
do Cardoso, no Contraditorium e no MeioBit. Partindo dessa proporção, selecionamos 38 posts de 2005 a 2011 entre os meses que ficaram com a maior valoração entre comentários/post para cada blog. Assim, os posts mais comentados de cada mês, sendo um por ano, foram selecionados para as observações propostas pela pesquisa.

Em um sentido amplo, o impacto gerado com o advento da Internet e, por conseguinte, com as práticas sociais na Web, nos permite refletir sobre a importância das transformações tecnológicas observadas nas experiências comunicacionais. De fato, o surgimento e a incorporação de uma nova tecnologia implica em fenômenos considerados "novos" e geradores de potenciais rupturas com o que havia até então. A presente pesquisa pretende identificar que, antes de uma interrupção brusca, existe uma continuidade, em que hábitos "novos" e "velhos" coexistem até serem incorporados pelas pessoas envolvidas em interações e performances em ambientes digitais.

Com o objetivo de organizar as propostas apresentadas por este trabalho, a pesquisa encontra-se dividida em quatro unidades. Na primeira unidade será abordada a questão das práticas sociais e as transformações tecnológicas observadas no âmbito dos ambientes digitais. Na segunda unidade apresentamos a relação entre os processos de mediação e interações sociais como legitimadores de uma posição de destaque. Na terceira unidade serão expostos como os dados foram tratados, apresentando a metodologia usada para a análise em questão. $\mathrm{Na}$ quarta unidade será desenvolvida a análise propriamente dita dos dados colhidos e, por fim, as considerações acerca da investigação realizada. 


\section{De Anônimo a Microcelebridade: Web 2.0 e participação}

\subsection{Fama e Reconhecimento: a noção de celebridade}

Ao falarmos da microcelebridade torna-se imprescindível apresentarmos uma visão teórica acerca da noção de celebridade. A microcelebridade é o indivíduo que se tornou famoso por meio de suas interações e performances no circuito-blogue (BRAGA, A., 2008a). Tais interações performances são as razões pelas quais Carlos Cardoso se tornou notável nos ambientes digitais nos quais atua. Isso decorre do fato de que sua performance on-line recebe uma atenção maior pela posição de destaque que ocupa no circuito-blogue. Nesse sentido, a "voz" de Cardoso encontra amplitude dentro do grupo no qual se encontra inserido.

O reconhecimento do papel destacado, como microcelebridade, pressupõe uma série de performances, dentre as quais estão incluídas as participações de comentaristas nos blogs de Cardoso em análise. O elevado número de comentários consolida a popularidade do blogueiro e, ainda, o legitima dentro de uma hierarquia na qual a microcelebridade é a figura que se sobressai.

A "voz" da microcelebridade tem um peso maior dentro do circuito-blogue. Os blogs preferidos, os links inseridos nos posts, os produtos que usa e os lugares que frequenta acabam se tornando, por essa notoriedade, moeda de troca em favor daqueles(as) que buscam também se tornarem microcelebridades (BRAGA, A., 2008a). Ao receber a atenção de uma microcelebridade, por meio de alguma performance no circuito-blogue, esses indivíduos podem se tornar populares e passarem a desempenhar eles mesmos o papel de microcelebridade.

A popularidade de indivíduos como Carlos Cardoso guarda semelhanças com a celebrização de celebridades. Essa comparação parte das seguintes hipóteses: em primeiro lugar, a posição de destaque seria alcançada por meio do reconhecimento midiático, dos pares e da audiência formada em torno do indivíduo. Por conseguinte, as opiniões, os fatos, os comportamentos e papéis 
desempenhados por alguém considerado notório ganhariam destaque. Esse destaque, por sua vez, continuaria a ser exaltado por aqueles(as) que sustentam a sua fama. Como em um movimento cíclico, a popularidade seria legitimada institucionalmente, tendo em vista que existiria um conjunto de parâmetros capaz de "revelar" a aptidão à condição de célebre. A legitimação dada seria colocada em um nível coletivo, tendo em vista que muitos(as) poderiam reconhecer um indivíduo como famoso.

Diante das hipóteses expostas, tanto a celebridade quanto a microcelebridade seriam alçadas a uma posição de destaque por conta de um reconhecimento público. Nesse ponto, existiria o reconhecimento das mídias que popularizaram esses indivíduos, das pessoas que se equiparam a eles, além do público que passa a acompanhar essas figuras. Por fim, celebridades e microcelebridades estariam inseridas em circuitos que condicionam a notoriedade a uma série de parâmetros. Dentre os quais, serem reconhecidos(as) pelas mídias de massa (celebridades) e em ambientes digitais (microcelebridades). Essa forma de reconhecimento - midiática e do circuito-blogue - presumiria o destaque que a celebridade e a microcelebridade recebem nos cenários em que atuam respectivamente.

$\mathrm{O}$ estudo realizado pretende comentar algumas questões que levariam ao surgimento da celebridade e do culto gerado em torno de sua figura, tendo como ponto de partida as hipóteses expostas anteriormente. As questões levantadas aqui partem do pressuposto de que a celebridade é um indivíduo reconhecido publicamente por seus talentos ou por suas realizações. A ideia de talento, abordada aqui, compreende os dotes artísticos, os saberes ou as habilidades elencados como especiais, extraordinários ou únicos. Por sua vez, as realizações seriam fatos ou acontecimentos que recebem, na figura da pessoa que se envolveu nesses eventos, atenção das mídias. Tais eventos podem ser a participação em um reality show, o relacionamento com pessoas famosas, um acidente ou escândalo de grande repercussão, por exemplo (ROJEK, 2001). Entretanto, a celebrização de um talento ou de um acontecimento dependem do interesse das mídias de massa (imprensa, televisão, rádio, publicidade, por exemplo) para que esses eventos sejam levados ao conhecimento do público. Por sua vez, este público consumirá notícias e produtos, legitimando, por fim, essa posição destacada. 
Esse reconhecimento, por parte das mídias, do público e dos pares, passaria por uma série de variáveis, dentre as quais: a legitimação daquele(a) que viria a se tornar uma celebridade; a repercussão que a atuação dessa celebridade gera nas mídias de massa; e os valores simbólicos que esses indivíduos transparecem enquanto celebridades. Nesse sentido, abordaremos, portanto, o papel das celebridades enquanto produto das mídias de massa. Por serem instituições disseminadoras de paradigmas, as mídias de massa celebrizam pessoas, destacando características consideradas interessantes, como estilos de vida idealizados (MORIN, 1977).

Segundo Boorstin (1980), a celebridade é conhecida por sua notoriedade. Para o autor, o status alcançado por uma celebridade decorre da imagem delineada pelas mídias de massa, designando-a como uma marca, tal e qual um produto resultante de uma linha de produção (BOORSTIN, 1980). Sob esta ótica, a celebridade é consequência do interesse das mídias de massa em tornar a sua imagem um atrativo para audiências, dentro de parâmetros como: padrões de beleza, estilo de vida privilegiado, certa "liberdade" para desenvolver comportamentos polêmicos, por exemplo.

A notoriedade, ressaltada por Boorstin (1980), é sustentada pelos "pseudoeventos". Os "pseudoeventos" consistem na invenção de um acontecimento no qual os(as) envolvidos(as) criam circunstâncias para gerar a cobertura das mídias de massa, a fim de torná-los relevantes (BOORSTIN, 1980). Em pormenores, os "pseudoeventos" são acontecimentos pensados em uma tentativa de "glamourizar" o universo do qual as celebridades fazem parte, dando sentido à encenação dos fatos. Para Boorstin, os "pseudoeventos":

(1) Não são espontâneos, mas aparecem porque alguém planejou, introduziu ou incitou. Tipicamente, não é um acidente de trem ou um terremoto, mas uma entrevista.

(2) É introduzido primeiramente (nem sempre exclusivamente) pelo imediato objetivo de ser noticiado ou reproduzido. Portanto, sua ocorrência é arranjada para que seja conveniente de ser noticiado ou reproduzido nas mídias. [...]

(3) Sua relação com a suposta realidade da situação é ambígua. Seu interesse emerge em grande parte dessa mesma ambiguidade. Com relação a um pseudoevento a pergunta "O que isso quer dizer?" tem uma nova dimensão. Enquanto o interesse dos noticiários em um acidente de trem estão no que aconteceu e as reais consequências, o interesse em uma entrevista está sempre, em certo sentido, no se realmente aconteceu e no que podem ser os motivos disso. O que foi dito realmente significou o que foi dito? Sem alguma ambiguidade um pseudoevento não pode ser muito interessante.

(4) Normalmente tem por objetivo ser uma profecia realizável.[...] ${ }^{2}$ (BOORSTIN, 1980, pp. 11-12)

\footnotetext{
${ }^{2}$ Tradução da autora. No original: "It's not spontaneous, but comes about because someone has planned, planted, or incited it. Typically, it is not a train wreck or an earthquake, but an interview.
} 
Sob a perspectiva de Boorstin (1980), podemos dizer que os "pseudoeventos" compõem um dos elementos legitimadores da celebrização de um indivíduo. Isso decorre da transformação de algo considerado irrelevante em um acontecimento merecedor de cobertura pelas mídias. Nesse sentido, aqueles(as) que recebem atenção de mídias de massa são considerados(as) privilegiados(as), tendo em vista que nem todos(as) podem ter suas vidas retratadas em programas de TV ou em jornais, por exemplo.

Devido à amplitude das mídias de massa, um número maior de pessoas conhecerá os indivíduos celebrizados. Por conseguinte, estas pessoas tornar-se-ão famosas e, de certa forma, cultuadas por essas audiências. Dessa forma, encontramos aqui dois pontos legitimadores: os "pseudoeventos" das mídias de massa e as audiências que gravitam em torno delas. Gamson (1994) enfatiza a importância de as mídias funcionarem de uma forma encadeada, no sentido de que uma ação por parte de uma mídia encontre respaldo em um acontecimento de outra mídia. Assim como as ações dos(as) profissionais envolvidos(as) na "criação" e "manutenção" da celebridade.

Fabricar uma celebridade é claramente [...] um empreendimento comercial estabelecido, feito de profissões altamente desenvolvidas e ligadas e de subindústrias como relações públicas, advocacia ligada ao entretenimento, ao jornalismo e à fotografia de celebridades, à estética, a atividades físicas, ao gerenciamento, ao agenciamento, às vendas de novidades. Como portadoras da commodity central (a capacidade de conquistar atenção), as celebridades são elas mesmas um produto. Na verdade, o ambiente comércio-industrial em que elas foram desenvolvidas é reforçado pela linguagem e pela auto-percepção daqueles(as) que trabalham nisso. ${ }^{3}$ (GAMSON, 1994, p. 64)

(2) It is planted primarily (not always exclusively) for the immediate purpose of being reported or reproduced. Therefore, its occurrence is arranged for the convenience of the reporting or reproducing media. [...] (3) Its relation to the underlying reality of the situation is ambiguous. Its interest arises largely from this very ambiguity. Concerning a pseudo-event the question, 'What does it mean?' has a new dimension. While the news interest in a train wreck is in what happened and in the real consequences, the interest in a interview is always, in a sense, in whether it really happened and in what might have been the motives. Did the statement really mean what it said? Without some of this ambiguity a pseudo-event cannot be very interesting. (4) Usually it is intended to be a self-fulfilling prophecy. [...]".(BOORSTIN, 1980, pp. 11-12)

3 Tradução da autora. No original: "Celebrity making is clearly [...] an established commercial enterprise, made up of highly developed and institutionally linked professions and subindustries such as public relations, entertainment law, celebrity journalism and photography, grooming and training, managing and agenting, novelty sales. As carriers of the central commodity (attentiongetting capacity), celebrity performers are themselves products. Indeed, the commercial-industrial environment in which they are developed is underlined by the language and self-perceptions of those working in within it." (GAMSON, 1994, p. 64) 
Como parte de um círculo de ações interdependentes, a celebridade emerge em razão do interesse das mídias de massa. O destaque dado por esses meios ajuda a formar um público que, por sua vez, reforça o culto às celebridades.

Como Boorstin (1980) evidencia, as celebridades representam a visibilidade alcançada por meio das mídias de massa. Por essa razão, se diz que a sua fama é atribuída por esses meios, ainda que por intermédio de seus talentos, de suas realizações ou de suas performances (GAMSON, 1994). Logo, a fama de uma celebridade pode ser determinada pela visibilidade obtida nos suportes midiáticos que gerenciam, de certa forma, o seu reconhecimento público. A imagem estampada nas mídias de massa é o resultado final, qualificando a celebridade para ser reconhecida publicamente por seus talentos, por suas realizações ou por suas performances. Por conseguinte, será por meio desses veículos que o público dará ciência da fama da celebridade.

Antes de ocupar um lugar de destaque, a celebridade passou por estágios nos quais seus talentos e/ou suas realizações foram avaliados. O destaque só é alcançado mediante a ocorrência de algum acontecimento e que este seja considerado relevante para as mídias de massa (BOORSTIN, 1980). As mídias de massa desempenham um papel legitimador quando tratamos de celebridades. Por serem um produto desses veículos, as celebridades só existem porque as mídias de massa apoiam os eventos atrelados a seus nomes. Ou seja, cabe a esses meios dar legitimidade ao mundo criado para dar sentido à existência das celebridades em nossa sociedade.

Esse mundo é construído para que a celebridade não seja vista como uma personagem deslocada e desprovida de sentido (GAMSON, 1994). Por essa razão, a celebridade, de certa forma, precisa fazer parte de nossas vidas. Ela está nos filmes e programas de TV que assistimos, nas revistas e jornais que lemos e na publicidade dos produtos que consumimos. Essa "presença" nos ajuda a construir uma identificação e, em certo sentido, nos oferece uma parcela, ainda que pequena, da vida que a celebridade encena diante de nossos olhos. $\mathrm{O}$ interesse despertado por uma celebridade, por conseguinte, reitera valores simbólicos ligados a poder, ao sucesso profissional, a padrões de beleza e à legitimação de talentos e/ou realizações (ROJEK, 2001).

A celebridade pode ser tratada, portanto, como uma personagem criada para materializar as qualidades mostradas nos eventos relacionados a esses indivíduos. 
Esses eventos podem ser um filme, uma letra de música, um recorde desportivo, o(a) anônimo(a) que se torna famoso(a) repentinamente; o que é comum exaltado como extraordinário e, assim, munido de valores simbólicos importantes. Geralmente, as celebridades demonstram, por meio de imagens veiculadas nas mídias de massa, que foram designadas para levar um estilo de vida idealizado por muitos(as) (MORIN, 1989): sucesso financeiro; festas; bens de luxo; tratamentos de beleza exclusivos que se tornam tendências; etc. $\mathrm{O}$ simples fato de receberem atenção daqueles(as) que produzem programas de TV, editam colunas em jornais e revistas, por exemplo, denota o caráter especial desses indivíduos.

A condição especial da celebridade corrobora o distanciamento entre estes indivíduos e suas audiências (MARSHALL, 2004). Esse distanciamento, de certa forma, reforça o aspecto semidivinal das celebridades, tendo em vista que elas pertencem a um mundo do qual poucos(as) podem fazer parte. Analogamente, é como se as celebridades fossem chamadas a fazer parte de um "Olimpo" e, por essa razão, seus talentos e suas realizações remetessem a uma materialidade conciliada com o divinal (ROJEK, 2001). Por conseguinte, esta condição semidivinal desperta reações nas audiências: o culto a celebridades; as tentativas de incorporar o estilo de vida levado por essas pessoas; e, ainda, a própria busca para se tornar membro(a) desse "Olimpo das celebridades".

A ideia de ser uma celebridade decorre de uma forma de reconhecimento público. Na medida em que o reconhecimento público passa pelo que é registrado pelas mídias de massa, a celebridade ocupa um papel que representa, de certa forma, valores, desejos e ideais simbólicos. Esses elementos são determinados pelo contexto em que se vive e, com a amplitude das mídias de massa, refletem como esses valores podem ser incorporados por homens e mulheres. Nesse sentido, uma vez que o contexto seja modificado, bem como o tempo histórico seja transformado, a noção de fama e, consequentemente, de notoriedade recebem diferentes nuances. Essa diferenciação pode ser justificada pela mudança de valores entre as pessoas de diferentes tempos históricos. Por sua vez, as razões que sustentam o reconhecimento público, como resultante da materialização de valores simbólicos, podem ter elementos semelhantes.

A atuação da celebridade, sob os pontos apresentados, pode ser trabalhada conceitualmente por meio das noções de poder carismático (WEBER, 2004) e de poder simbólico (BOURDIEU, 1989). Ao relacionarmos esses dois conceitos, 
pretendemos esclarecer que o papel ocupado pela celebridade é revestido de uma forma de poder, ainda que não seja determinado por imposição ou por meio de força física. $\mathrm{O}$ que a celebridade representa exerce um fascínio sobre audiências e é celebrizado como algo que pode ser buscado e, portanto, pode estar presente nas atividades cotidianas. Por representarem valores (positivos ou negativos), a celebridade assume, além de uma posição de destaque, uma potência. Essa condição pode nos ajudar a compreender a microcelebridade como pessoa célebre no seu circuito-blogue.

A celebridade exerce fascínio sobre os(as) demais. Quando está nas mídias de massa, quase sempre representa o incomum, o chocante, o extraordinário. A vida ora é completamente perfeita, ora é repleta de adversidades as quais não seriam possíveis às pessoas comuns (CASHMORE, 2006). Tais extremos parecem denotar que a celebridade não é uma pessoa comum, vivendo uma rotina considerada enfadonha.

O fascínio sobre celebridades guarda semelhanças com o conceito de carisma proposto por Max Weber (2004). Segundo Weber (2004), carisma é a qualidade que uma pessoa possui capaz de despertar interesse dos(as) demais membros do grupo, por meio do reconhecimento de seus talentos e/ou de suas realizações no âmbito de uma sociedade. Consequentemente, por guardar essa qualidade, esse indivíduo passa a deter uma forma de poder, o poder carismático. O poder carismático é conquistado, portanto, por meio do reconhecimento dos talentos e/ou das realizações de indivíduos e, precisamente, pelo aspecto extraordinário que envolveu a obtenção desse reconhecimento. Portanto, o poder carismático, segundo Weber (2004), é concedido a heróis, sábios, curandeiros e, por fim, a artistas por seus talentos e/ou realizações considerados marcantes. $\mathrm{O}$ aspecto quase divinal desses acontecimentos é determinado pela dificuldade ou pela raridade desses talentos e/ou dessas realizações.

O reconhecimento público proveniente do carisma e, logo, da existência do poder carismático é determinado pelos indivíduos de um grupo do qual esse(a) líder carismático(a) faz parte (WEBER, 2004). Essas pessoas, com base nos valores simbólicos que têm como referência, reconhecem os(as) dotados(as) de carisma como seres especiais. Em algumas ocasiões, como aponta Weber (2004), os(as) dotados(as) de carisma são referenciados(as) como semideuses, tendo em vista que possuem habilidades incomuns. Por essa razão, aqueles(as) que possuem 
qualidades extraordinárias, demonstradas por meio de acontecimentos e/ou realizações que favorecem o grupo como um todo, detêm o poder carismático. Por isso, essas pessoas influenciam hábitos e costumes por meio da legitimação de valores simbólicos pré-existentes, tornando-se referência para o grupo.

Nesse sentido, as conquistas heroicas ou religiosas, apontadas por Weber (2004), seriam destacadas nas performances públicas. No caso das celebridades, a performance pública passa pelo aval das mídias de massa. Já para as microcelebridades, emergem como meios eficientes para consolidar um circuitoblogue próprio e, por conseguinte, obter a legitimação de outras microcelebridades por conta do sucesso alcançado.

No caso das microcelebridades, podemos falar em uma conquista de público. Por exemplo, um indivíduo, para se tornar microcelebridade, precisa chegar a um grupo de pessoas com interesses semelhantes aos seus. A forma de se apresentar e como realiza as suas performances devem ser considerados por esse indivíduo, na tentativa de construir uma persona que seja carismática para esse grupo. O sentido de carisma, apontado neste instante, pressupõe a afinidade de valores simbólicos e, ainda, a realização de uma performance que, de certa forma, é percebida como "especial".

A proposição de um poder carismático por Weber (2004) nos fornece meios para compreender a lógica de exaltar alguém somente por suas qualidades. Vimos que se torna imprescindível a existência de uma realização e/ou acontecimento considerado extraordinário para que exista o reconhecimento público. Esse reconhecimento público é determinado pelo contexto em que um grupo vive. Portanto, podemos entender que revela-se imprescindível a existência de algum elemento relevante, para aquele contexto no geral, que seja capaz de alçar uma pessoa comum à condição de herói(na).

Sob esse entendimento, recorremos à noção de poder simbólico de Bourdieu (1989), a fim de aprofundarmos a compreensão acerca do reconhecimento obtido pelas celebridades e para as performances de microcelebridades. Bourdieu, em um sentido mais completo, discorre sobre uma forma de poder, "o poder simbólico é, com efeito, esse poder invisível o qual só pode ser exercido com a cumplicidade daqueles que não querem saber que lhe estão sujeitos ou mesmo que o exercem.” (BOURDIEU, 1989, pp.8-9). 
O poder simbólico guarda semelhanças com a questão do poder carismático proposta por Weber (2004). Todavia, em um sentido mais completo, Bourdieu (1989) esclarece que o poder simbólico é alcançado quando existe também o reconhecimento por parte das instituições às quais nos voltamos quando buscamos parâmetros para a realização de práticas sociais, como a legitimação de performances de celebridades e microcelebridades. No texto de Weber (2004), o autor aponta que, com o passar o tempo, aquele(a) que detêm o poder carismático será agregado às práticas legitimadoras dessa forma de poder. Entretanto, a manutenção de sua condição especial depende de mostras contínuas de que ainda é merecedor(a) dessa posição de destaque (WEBER, 2004).

Em nosso caso, particularmente, a noção de poder simbólico remete-se às estratégias lançadas para se determinar quem pode ocupar a posição de celebridade. Bourdieu nos fornece um panorama interessante.

Todo o funcionamento do sistema está dominado pela existência ininterrupta de concursos coroados por recompensas honoríficas, entre os quais o mais importante é o concurso anual do Grande Prémio, que garante ao laureado estadia na Villa Médicis. Nada há de surpreendente, pois, quando se encontram no sistema todas as características das instituições sujeitas a esta lógica, como as classes preparatórias para as escolas superiores: a docilidade extraordinária que ele supõe e reforça entre os alunos, mantidos por longo tempo numa dependência infantilizante pela lógica da competição e as expectativas insensatas que ela suscita (a abertura do Salão dava azo a cenas patéticas); a normalização operada pela formação colectiva em "atelier", por meio de seus ritos de iniciação, das suas hierarquias ligadas tanto à antiguidade como à competência, os seus cursos por etapas e por programas estritamente definidos. (BOURDIEU, 1989, pp. 258-259)

Como podemos ver, a Academia de Belas Artes ocupa a posição institucional, reunindo os valores reconhecidos, nesse caso esteticamente, para dizer aqueles(as) que seriam aptos(as) a se tornarem artistas de renome. Por meio de concursos, cuja avaliação passa pelas mãos de jurados(as) reconhecidos(as) no meio, a Academia de Belas Artes legitima aqueles(as) que possuem talentos distintos e, portanto, merecem ser exaltados(as) pelos(as) apreciadores(as) de artes plásticas.

Em uma lógica bastante parecida, as celebridades ascendem em decorrência do interesse existente em suas personas públicas. As mídias de massa, por produzirem e promoverem produtos culturais, seriam, portanto, capazes de dizer quem estaria apto(a) ou não a ocupar esse papel destacado. Nesse sentido, a atuação das mídias de massa reside na escolha dos(as) privilegiados(as) a entrarem no "Olimpo das celebridades". Consequentemente, a visibilidade conseguida por meio das mídias de massa torna a celebridade real. No instante em 
que a imagem de uma pessoa é estampada nas mídias de massa e existe uma repercussão em torno de seu nome, este indivíduo é celebrizado; este indivíduo torna-se celebridade.

O culto a celebridades encontra algumas variáveis apresentadas nos trabalhos de Weber (2004) e de Bourdieu (1989). Primeiramente, a necessidade de uma motivação que torne a celebridade apreciável publicamente. Weber (2004) sugere a condição extraordinária evidenciada por um indivíduo; Bourdieu (1989) menciona o talento enquadrado e determinável por instituições. No caso das celebridades, é a sucessão de acontecimentos que pode ser criada em torno de seu nome, tal e qual Boorstin (1980) definiu na forma dos "pseudoeventos."

Em segundo lugar, o talentos e as realizações das celebridades precisam ganhar notoriedade para que, assim, os acontecimentos possam ser vistos pelas pessoas. Dessa forma, o reconhecimento público é resultado do interesse de indivíduos, como Weber (2004) apontou no caso do poder carismático, e, ainda, mediado pelas mídias de massas. Nesse caso, as mídias de massa incorporam a institucionalização dos talentos e das realizações.

A noção de celebridade está ligada às mídias de massa. A sua existência depende do reconhecimento dado por esses meios à performance de indivíduos que desempenham papéis de celebridades. Portanto, a representatividade de uma celebridade é revestida de sentido enquanto as estratégias e mecanismos de promoção das mídias de massa atuarem na consecução de tal intento. Por isso, em alguns momentos, as celebridades são descritas como reféns de suas imagens e, portanto, destituídas de habilidades que não sejam seus próprios nomes ou sua presença.

Em contrapartida, conforme mencionado anteriormente, as celebridades dependem de algo para justificar a sua promoção. Seja, de fato, um talento, um acontecimento de grande repercussão do qual participou ou, ainda, algum atributo físico exaltado como incomum. Nesse sentido, a noção de celebridade, embora atrelada a mídias de massa, é determinada por um conjunto de fatores nos quais essas mídias atuam como legitimadoras dessa condição especial. Esse conjunto de fatores compreende, além dos talentos e quaisquer outros atributos extraordinários e as mídias de massa, o público que consome os produtos relacionados a celebridades. 
Gamson (1994) aponta que o espaço de destaque ocupado pelas celebridades é obtido mediante o trabalho de uma equipe. Esta equipe "achará" o local adequado e construirá uma imagem pública para a celebridade em potencial. Em primeiro lugar, o trabalho que "revelará" o seu rosto e o seu nome. Por conseguinte, os "eventos" que legitimarão a sua condição notória e, logo, a sua fama. Os "eventos", como sugere Gamson (1994), compõem o conjunto de ações que dão visibilidade a uma celebridade. Ou seja, pode ser a première de um filme, um editorial em uma revista de renome, uma entrevista concedida a um(a) apresentador(a) famoso(a), uma premiação, etc. Tais ações promovem o nome da celebridade e, em certo sentido, organizam uma identidade em torno de sua figura.

A microcelebridade, por sua vez, precisa fazer incursões por diversos ambientes digitais. Por meio dessas participações, o indivíduo torna seu nome conhecido entre os(as) demais participantes. À medida que adquire credibilidade ou, ainda, realiza algo que merece atenção, essa pessoa pavimenta a sua posição destacada diante dos(as) demais. Nesse sentido, a performance voltada para ambientes digitais - como, por exemplo, a forma de se apresentar e de se comportar dentro do grupo - acaba por se tornar um evento no qual as précondições para se tornar microcelebridade foram colocadas e legitimadas pelas performances daqueles(as) que participam desses ambientes. Logicamente, tais condições variam, assim como o tempo e o percurso para se alcançar tal posição. $\mathrm{O}$ que se pretende com isso é enfatizar que, para microcelebridades, existem eventos nos quais a sua condição de destaque é construída. Um desses eventos é a participação por meio de comentários em posts de blogs.

A questão da identidade, apontada anteriormente, remete ao comportamento padrão assumido - ou definido - pela celebridade (e sua equipe). Esse comportamento constituirá a referência e estará intimamente ligado à imagem da celebridade. Sua figura pública legitima essa identidade, denotando uma imagem coerente entre a sua performance e a sua representação. Ou seja, a fachada pública assumida (GOFFMAN, 2002) reflete como a celebridade deseja ser reconhecida e a identidade assumida enquanto representar o seu papel naquele cenário.

Portanto, existe uma coerência exigida enquanto a celebridade for uma figura pública. Isso reflete-se nos modos como as mídias de massa retratam qualquer acontecimento ligado ao nome da celebridade. Por um lado, enquanto a celebridade transparecer a identidade acordada tacitamente entre ela, as mídias de 
massa e seu público, seu objetivo é continuar a dar mostras de que é merecedora do lugar ocupado (CASHMORE, 2006). Em contrapartida, se o comportamento não for coerente com a imagem pública da celebridade, uma campanha realçando seus aspectos negativos poderá ser lançada para reforçar a incoerência e o aspecto marginal de suas condições (idem). Os aspectos negativos, nesse caso, atuam em contraposição às qualidades materializadas pela celebridade e incorporadas em sua identidade pública.

No âmbito das microcelebridades, o circuito-blogue é o espaço por meio do qual um indivíduo realizará seus feitos e poderá se tornar conhecido. $\mathrm{O}$ circuitoblogue configura-se pelo conjunto de interações existentes e realizadas em ambientes digitais (BRAGA, A.,2008a). Os(As) participantes desses ambientes interagem entre si e buscam por interações que sejam interessantes para eles(as). A ascensão de um indivíduo, e a consequente, visibilidade obtida, é alcançada por meio de um reconhecimento público, assim como acontece no caso das celebridades. Entretanto, esse reconhecimento público limita-se ao circuito-blogue em que se encontra inserido(a).

O reconhecimento público de uma microcelebridade é determinado pela atenção que ela consegue despertar em seus pares no circuito-blogue. A sua atuação em ambientes digitais precisa ser reconhecida como relevante, especialmente para as temáticas abordadas nesse contexto. As suas habilidades precisam ser complementares às interações existentes. Todavia, essa complementaridade precisa chamar atenção de alguma forma.

O reconhecimento público no circuito-blogue pode ser tratado na forma do carisma, tendo em vista que a microcelebridade em potencial precisa usar seus talentos para materializar valores simbólicos caros ao grupo do qual ela mesma faz parte e, portanto, encontra-se supostamente familiarizada. Por essa razão, podemos falar que exista uma crença, como Weber (2004) aponta, de que aquele indivíduo representa algo, por meio de suas interações e de sua performance, com o qual podemos nos identificar. Logo, existe o interesse em acompanhá-lo(la). Por conseguinte, esse poder carismático depende do reconhecimento dos(as) outros(as) que ocupam posições semelhantes, ou seja, são também microcelebridades.

No cenário do circuito-blogue, as outras microcelebridades ocupam um papel destacado em uma hierarquia simbólica. Por essa razão, as 
microcelebridades, em seu conjunto, não chegam a compor uma instituição para que se determine um poder simbólico. Por essa razão, a fama das microcelebridades é limitada ao circuito-blogue. Porém, o crescente interesse das mídias de massa pela suposta influência que esses indivíduos exercem sobre seus(as) seguidores(as), transforma o cenário. Sob este aspecto, a fama das microcelebridades pode ser institucionalizada pelas mídias de massa, tendo em vista que esses indivíduos passam a aparecer nesses suportes e, por conseguinte, legitimarem-se, de alguma forma, como celebridades.

\subsection{Web 2.0 e Participação}

Ambientes digitais, como blogs e páginas em sites de redes sociais, revelam algumas características quanto à forma de conquistar notoriedade a partir desses espaços. Por meio de interações entre donos(as) e/ou administradores(as) destes ambientes e os(as) frequentadores(as) dessas páginas, é possível conquistar audiências e, consequentemente, tornar-se famoso(a). Por exemplo, a publicação de comentários em um blog, além de pressupor um interesse em registrar considerações sobre os posts, quantifica publicamente o número de comentaristas. Por conseguinte, essa forma de participação converte-se em um dos parâmetros para que um(a) blogueiro(a) comece a obter destaque dentro do grupo em que atua. Nesse sentido, aquele(a) que adquire popularidade sob estas circunstâncias é denominado(a), segundo Adriana Braga (2008a), microcelebridade. O sucesso desse indivíduo, conforme a pesquisadora define, é limitado ao circuito-blogue ${ }^{4}$ (BRAGA, A., 2008a).

Interações em blogs, como a troca de comentários entre visitantes desses espaços, seriam parte do que se convencionou chamar de Web 2.0. Os ambientes e interfaces (aquilo que é visualizado nos navegadores/browsers), sob a ótica da Web 2.0, seriam voltados para o(a) usuário(a) comum, com pouco ou nenhum conhecimento técnico relacionado ao funcionamento de Internet e de Web (RETTBERG, 2008). Esse termo ganhou destaque em 2004, quando, na ocasião, Tim O'Reilly sugeriu uma nova versão da World Wide Web. Com base nessa designação, a Web se tornaria acessível ao(à) usuário(a) comum, com a possibilidade de criação websites dinâmicos e "editáveis" (O’REILLY, 2009). No

\footnotetext{
${ }^{4}$ A definição do conceito de "circuito-blogue" será detalhada mais adiante.
} 
jargão da área tecnológica, a indicação " 2.0 ” se refere a uma versão aprimorada de um software ou de um hardware.

A mudança sugerida por O'Reilly fez parte de uma reestruturação pela qual empresas de tecnologia passaram no início dos anos 2000. Essa transformação resultou da crise que atingiu diversas companhias da área, motivada pela alta especulação de valores no mercado de ações e do real retorno que tais empreendimentos poderiam gerar para seus(suas) investidores(as) (O'REILLY, 2009). Como resultado, houve a necessidade de pensar em uma Web que contasse com o perfil técnico de desenvolvedores (as) e, especialmente, com a participação de pessoas com pouco ou nenhum conhecimento em Internet e em Web.

Os blogs podem ser considerados parte da Web 2.0, tendo em vista que disponibilizam uma plataforma de publicação de conteúdos (textuais, audiovisuais e/ou sonoros) de uma forma relativamente fácil. Essa acessibilidade é observada na interface de publicação de posts, similar a um programa de edição de textos, assim como o processo de escolha e da eventual edição do layout que ficará visível para os(as) visitantes do blog (RETTBERG, 2008).

A palavra "blog" é uma redução da palavra inglesa weblog que, por sua vez, significa registro na Web (web + log) (HOOKWAY, 2008; RETTBERG, 2008). A pessoa responsável por publicar esses registros é denominada web logger. A facilidade com que essas postagens eram publicadas na Web pode ter sido um dos fatores responsáveis pelo sucesso e pela popularização dos blogs, além do fato de esses serviços serem gratuitos (RETTBERG, 2008). O processo de disponibilização dessa página pessoal é bastante simples, bastando o cadastro e a posterior publicação de posts. O(A) autor(a) conta, ainda, em alguns casos, com a opção de deixar o conteúdo de seu blog restrito a pessoas convidadas.

Antes de prosseguirmos, façamos uma breve comparação com base no complexo conhecimento exigido para a elaboração de um website antes dos blogs. A criação e o desenvolvimento de websites requeriam um saber técnico elevado sobre a elaboração da página, para que a parte a ser visualizada pudesse se tornar visível nos navegadores (RETTBERG, 2008). Quaisquer alterações posteriores ao upload $^{6}$ do website, como a atualização de conteúdos, eram feitas somente por

\footnotetext{
${ }^{5}$ Hoje o termo blogger, ou blogueiro(a) em português, é mais usado (RETTBERG, 2008).

${ }^{6}$ A ação de upload significa colocar o site "no ar". Ou seja, enviar os arquivos que tornam a interface visível para usuários(as) para o servidor que hospeda esses documentos.
} 
meio da modificação do arquivo que deu origem à parte do website que aparecia nos navegadores. Portanto, era necessário conhecer os códigos ${ }^{7}$ referentes à linguagem de programação usada para a criação do website.

Com a evolução dos serviços disponibilizados na Web, criar um website pessoal - neste caso, um blog - se tornou um procedimento menos complexo (THELWALL, WOUTERS apud HOOKWAY, 2008). Em vez de as alterações serem feitas somente por meio da modificação do arquivo que deu origem ao website, usando programas especializados e técnicos, esta edição poderia ser feita a partir de um sistema de gerenciamento de conteúdo (Content Management System - CMS), oferecido por websites especializados no cadastro de blogueiros(as) em potencial (RETTBERG, 2008.).

Blogueiros(as) [...] escolhem seu próprio template e normalmente gastam um tempo considerável ajustando como o seus blogs vão ficar e como eles funcionarão. [...] Um blog [...] não pode ser lido simplesmente pelo que está escrito nele, mas será sempre visto como a soma de seus textos, do layout, das conexões e dos links, e do ritmo. ${ }^{8}$ (RETTBERG, 2008, p. 4)

Por meio do CMS é possível mudar o conteúdo sem precisar mexer nos intrincados códigos de linguagens de programação e, por sua vez, sem depender, a todo instante, de programadores(as) experientes na área. O CMS é composto por conjuntos de modelos de páginas prontos (templates), porém passíveis de personalização (RETTBERG, 2008). O sistema varia de um website para outro, todavia a essência é a mesma. Como exemplos mais famosos de CMS, podemos citar o LiveJournal, o Blogger e o Wordpress.

Os registros de um blog são compostos de textos, conteúdos audiovisuais e/ou sons disponibilizados de forma que o mais recente apareça sempre nas primeiras posições (BRAGA, A., 2008a). Essas primeiras posições compõem o espaço que é visto logo que acessamos o blog. A interface visível para o(a) dono(a) e/ou administrador(a) do blog, no momento da criação de um post, assemelha-se a de um editor de textos como o Microsoft Word. Os comandos e ferramentas para formatação são parecidos, o que dá familiaridade ao(à) usuário(a). A partir da área administrativa de um blog é possível editar conteúdos

\footnotetext{
${ }^{7}$ Como exemplo de linguagem de programação para websites é o PHP. Essa linguagem possibilita a criação de documentos html que constituem a parte visível do website.

${ }^{8}$ Tradução da autora. No original: "Bloggers [...] choose their own template and often spend a considerable time adjusting the way their blogs look and work. [...] A blog [...] cannot be read simply for its writing, but will always been seen as the sum of writing, layout, connections and links, and tempo." (RETTBERG, 2008, p.4)
} 
já publicados, categorizá-los, acompanhar as visitas realizadas e, ainda, controlar/moderar os comentários feitos por visitantes em cada postagem.

Os conteúdos publicados em um blog são conhecidos como posts e podem ser de ordem textual, audiovisual, sonora e/ou com referências a links ou a outros blogs. A temática dos conteúdos, normalmente, está relacionada aos interesses daqueles(as) que mantêm esses espaços na Web (BRAGA, A., 2008a). Assim como um website, os blogs possuem endereço e um design - conhecido como webdesign - cuja visualização ocorre por meio de linguagens de programação e de estilização, já embutidas nos modelos (templates) disponibilizados pelo CMS.

Segundo Kozinets, o blog é "um lugar em potencial para uma comunidade e uma cultura on-line""9 (KOZINETS, 2012, p. 189). A noção de comunidade e a de cultura, inferidos por Kozinets, relacionam-se ao nível de agregação que o blog pode estimular entre os(as) frequentadores(as). Além disso, ao observar tanto os posts quanto a seção de comentários de um blog, notamos uma forma peculiar de se comportar e uma linguagem própria àquele grupo. Isso se torna determinante na definição de quem está dentro do grupo ou daqueles(as) que são forasteiros(as). Ainda, as temáticas abordadas em um blog atingem audiências com interesses semelhantes aos publicados pelo(a) dono(a) e/ou administrador(a) do blog.

Ao longo dessa seção, fizemos menção constante às palavras dono(a) e administrador(a) quando falamos sobre os blogs. Essa citação se faz pertinente no sentido de expor que um blog pode ter somente um(a) dono(a) ou contar com vários(as) autores(as). Em blogs que contam com diversos(as) autores(as), costuma-se autorizar a participação dessas pessoas por "níveis de permissão" (RETTBERG, 2008). Tais níveis vão desde somente a publicação de posts até o nível de dono(a) do blog. No caso dos(as) administradores(as), eles(as) têm autonomia para editar qualquer conteúdo, moderar comentários e, ainda, modificar o design do blog. Achamos interessante explicar essa distinção, tendo em vista que isso ocorre em um dos blogs analisados por essa pesquisa, o MeioBit, no qual Carlos Cardoso possui uma coluna e é editor de conteúdo, mas não é o dono do blog.

No que concerne à possibilidade de fazer referências, os blogs possuem dispositivos que permitem o acompanhamento de quem menciona os conteúdos

9 Tradução da autora. No original: "[...] a potential site of online community and culture." (KOZINETS, 2012, p. 189) 
existentes nesses ambientes. O monitoramento, por parte do(a) dono(a) e/ou administrador(a), ocorre no próprio espaço onde o post é publicado e, ainda, no espaço dedicado à administração do blog. As duas possibilidades de monitoramento são o ping back e o track back (RETTBERG, 2008). O primeiro consiste no monitoramento propriamente dito e, por meio desse sistema, é possível acompanhar menções feitas ao link da postagem em blogs e em outros sites, como redes sociais. $\mathrm{O}$ track back funciona toda vez que alguém menciona $\mathrm{o}$ link dentro de outro post. Por meio desse sistema, é possível ver onde essa menção ocorreu e quem a fez.

O sistema de um blog fornece, ainda, o recebimento de atualizações via email ou via um leitor de feed. A palavra feed se refere, nesse caso, à "alimentação" de um website ou de um blog. Ou seja, à medida que o website ou o blog é atualizado, estes dispositivos são "alimentados" com novos conteúdos (RETTBERG, 2008). O funcionamento do feed parte do seguinte princípio: um indivíduo seleciona os links de websites e de blogs dentre os quais deseja acompanhar. A partir dessa escolha, este indivíduo receberá, diretamente em seu leitor de feeds, todas as atualizações referentes aos conteúdos desses ambientes. Dessa forma, ao optar pelo recebimento dos feeds, a pessoa não necessariamente precisa ir ao website ou ao blog, a menos que deseje realizar comentários sobre os conteúdos publicados.

Um aspecto importante do blog consiste na possibilidade de outras pessoas deixarem suas considerações acerca dos conteúdos publicados por meio de comentários. A seção de comentários, incorporada à interface do blog, permite a indivíduos expressarem sua opinião. Além disso, esse lugar acaba por estabelecer um espaço interacional cujo ponto de encontro é tanto a microcelebridade quanto os posts publicados no blog em questão (BRAGA, A., 2008a). Logo, em termos numéricos, os blogs mais populares e mais visitados contariam com maior número de interações e performances ocorridas nas seções de comentários.

Como vimos, a seção de comentários constitui um ambiente no qual pessoas podem expor suas opiniões acerca do conteúdo publicado em um blog. Entretanto, a popularidade obtida por meio dessas interações e performances é construída, ainda, por meio de outras ações, como a publicação de comentários em outros blogs, sugestão ou retribuição de visitas entre blogs, troca de links e menções 
(track back ou ping back). Estas ações são realizadas fora do espaço dos blogs e compõem um sistema denominado circuito-blogue (BRAGA, A., 2008a).

O circuito-blogue é composto de um conjunto de performances e de interações empreendidos entre microcelebridades e interessados(as) em acompanhar estas microcelebridades. Segundo Adriana Braga, o circuito-blogue é um:

[...] circuito comunicacional estabelecido entre co-participantes de diferentes sites de relacionamento, realizado através de troca de links e visitas recíprocas. O sistema de retribuição de visitas parece ser a força motriz que constitui o circuito interacional em torno dos blogs. Nesses espaços, é possível encontrar comentários de outros/as blogueiros/as (acompanhados do endereço eletrônico), formando uma rede de interação através de referências mútuas. (BRAGA, A., 2008a, p. 278)

No circuito-blogue (BRAGA, A., 2008a) os(as) participantes, e microcelebridades em potencial, percorrem outros blogs, páginas em sites de redes sociais, usam sistemas de aprimoramento de buscas com o objetivo de chamar atenção para seus blogs (otimização para motores de busca $^{10}$ ou links de publicidade) e páginas pessoais em redes sociais on-line. As interações ocorrem a partir de elogios ou críticas a conteúdos; de sugestões ou conteúdos complementares ao post ou atualização de status, nos casos de redes sociais; de trocas de links e sugestões de blogs; e, ainda, pelas tentativas de estabelecer contato com microcelebridades e outros(as) participantes.

Nesta pesquisa, denominaremos o circuito-blogue formado em torno de Carlos Cardoso de "circuito-Cardoso". A dinâmica observada no "circuitoCardoso" é fundamentada a partir da persona digital do blogueiro e do interesse em acompanhá-lo em ambientes digitais. Com base nisso, podemos perceber uma espécie de hierarquia na qual Cardoso é a figura de maior destaque, funcionando, por conseguinte, como uma espécie de mediador para seus seguidores(as). Um exemplo disso pode ser notado nas observações feitas pelo blogueiro acerca da dinâmica desse circuito:

"Ganhe dinheiro discriminando seus usuários", publicado no Contraditorium em 13/12/2006.

$[\ldots]$

O problema aqui é que quando começamos a monetizar um blog, a tendência é perdermos a timidez, colocando mais e mais banners escandalosos, que infelizmente são os que funcionam melhor.

${ }^{10}$ Search Engine Optimization - SEO. Definição para SEO: "[...] search engine optimizers tweak Web sites to make them as findable as possible." (RETTBERG, 2008, pp. 143-144) 
$\mathrm{O}$ visitante frequente tende a ficar cego para esses banners, então acabamos poluindo a página de uma forma que não induz o visitante diário a clicar, mas cria ruído, poluição. $\mathrm{O}$ banner escandaloso entretando funciona muito bem para o cliente eventual.

$\mathrm{O}$ que precisamos é do melhor de dois mundos, um jeito de exibir banners escandalosos para os paraquedistas do Google e anúncios mais discretos para os visitantes dos feeds, ou os diretos. [...]

A implementação foi muito, muito simples. Basicamente um bloco de PHP que detecta a origem do visitante. Se vier do Google ou do Yahoo, é exibido um conteúdo. Caso contrário, é exibido um segundo conteúdo.[...]

simples técnica você vai poder dar mais conforto e qualidade de acesso a seus visitantes freqüentes, e ao mesmo tempo expor o máximo de peças para que os paraquedistas do Google deixem mais do que lembranças, ao irem embora nos próximos minutos.

No trecho citado, Cardoso explica suas experiências e suas táticas para aumentar a renda de seus blogs a partir do volume de visitantes desses espaços. Nesse caso, o blogueiro demonstra conhecer tanto a dinâmica de performances e de interações quanto o sistema dos sites de busca. A partir dessa descrição, Cardoso revela, de certa forma, como o seu circuito-blogue funciona e, especialmente, o poder conquistado ao ter essa noção.

Os blogs ampliaram a participação de pessoas em ambientes digitais, especialmente se levarmos em consideração o funcionamento desse dispositivo. A publicação de informações em uma página pessoal não é capaz de atrair, por si só, outros(as) interessados(as) em acompanhar tais produções. Tendo em vista que é preciso estabelecer performances e envolver-se em interações com um público em potencial, o(a) blogueiro constrói sua visibilidade a partir de um circuito performático. Por exemplo, o "circuito-Cardoso" possui elementos caracterizadores de sua persona digital, de suas audiências e, principalmente, de uma dinâmica cara ao grupo de seguidores(as) do blogueiro. Em razão disso, a microcelebridade emerge e torna-se mediadora de seu próprio circuito-blogue ${ }^{11}$.

\subsection{Carlos Cardoso, seus blogs e a cultura geek}

A possibilidade de fazer comentários relacionados a um conteúdo pressupõe o interesse do(a) comentarista em expressar algo com base no que o(a) blogueiro(a) publica. Esse interesse pode ser uma concordância ou uma discordância em relação ao post. Em ambientes digitais, os comentários podem medir a popularidade de um(a) blogueiro(a). Quanto maior o número de

${ }^{11}$ Embora reconheçamos a ampla literatura existente sobre cibercultura e ambientes digitais, a presente pesquisa privilegia aspectos relacionados à microssociologia de orientação interacionista. 
comentários feito em uma postagem, mais popular é o(a) dono(a) e/ou administrador(a) do blog. Por sua vez, essa popularidade é determinada, ainda, pelas interações e performances tanto da parte daqueles(as) que seguem o blog em questão, quanto daquele(a) que produz conteúdo para esse suporte.

Segundo Adriana Braga (2008a), indivíduos que fazem sucesso a partir de interações em ambientes digitais são denominados microcelebridades. Segundo a pesquisadora, as microcelebridades são:

\begin{abstract}
pessoas que se notabilizaram por alcançar uma valor simbólico a partir de sua performance nos ambientes digitais [...]. Trata-se de processos midiáticos altamente seletivos em termos de audiência, na medida em que esses ambientes de mídia conquistam um público específico correspondente à temática tratada. O prefixo "micro" se refere à produção de fenômenos midiáticos análogos àqueles observados nos Meios de Comunicação de Massa, nos quais o/a personagem se celebriza no seu ambiente, entretanto, em pequena escala. Esses processos operam como elemento importante na formação do circuito-blogue [...], na medida em que estabelecem uma hierarquização simbólica, tácita, entre os blogs e seus/suas autores/as, decisiva na configuração desta dinâmica comunicacional e na consolidação da legitimidade de seus conteúdos. (BRAGA, A., 2008a, p. 280)
\end{abstract}

Carlos Cardoso é uma microcelebridade por reunir características caras ao termo: seu sucesso foi construído em ambientes digitais, por meio de interações com outras pessoas; a sua atuação é demarcada por um nicho específico tecnologia; as interações e performances em ambientes digitais, bem como o nicho de atuação, limitam a sua popularidade para dentro das fronteiras de seu circuito-blogue. Cabe ressaltar, ainda, as linguagens e referências que Carlos Cardoso dispõe em seus posts, as quais estimulam a interpretação tanto os(as) iniciados(as) quanto aqueles(as) que discordam das ideias do blogueiro.

A análise parte de três blogs: Blog do Cardoso, Contraditorium e MeioBit. O Blog do Cardoso e o Contraditorium foram criados por Cardoso, ao passo que no MeioBit o blogueiro assume o papel de editor e de colunista. Além desses blogs ${ }^{12}$, Carlos Cardoso possui: uma página no microblog/rede social Twitter; o Tumblr Sem Foco, em que publica curiosidades e "virais" da Web; o blog Farofa Midiática, que conta com posts relacionados a resenhas sobre seriados televisivos.

\footnotetext{
${ }^{12} \mathrm{O}$ uso de outros dispositivos, como perfis em redes sociais, faz parte do circuito-blogue de uma microcelebridade. Notamos uma articulação entre performances observadas nos blogs em análise e as páginas em redes sociais de Cardoso, especialmente em seu perfil no Twitter. Ainda que cada ambiente digital tenha características que orientam performances e interações, existe uma série de ligações que parecem dar credibilidade à performance de Cardoso. Entretanto, para que possamos compreender o funcionamento do circuito-blogue, achamos pertinente analisar, em um primeiro momento, aquilo que consideramos ser a base para essas performances e interações: os blogs.
} 
Cardoso faz sua apresentação à blogosfera em uma seção denominada "Quem sou eu" presente no Blog do Cardoso. Tal seção é mencionada em outros ambientes digitais nos quais Cardoso atua. Devido à presença de elementos bastante ricos, relacionados à persona digital de Cardoso, faremos uma análise dedicada a esse post em especial na seção "O Eu e os Outros" dentro da unidade "O Circuito-Cardoso: Aspectos Analíticos". Por essa razão, separamos apenas alguns trechos para uma breve ilustração da persona digital de Cardoso.

\begin{abstract}
Ganhei meu primeiro micro, um CP-200, no auge da Reserva de Mercado, uma época negra, digo, afro-brasileira, onde nossa independência tecnológica iria acontecer com a reinvenção da roda. [...]

Continuei como micreiro (era esse o termo, bem melhor que "internauta") mas desviei minha atenção para outras áreas criativas. [...]

Depois descambei para a Informática de novo. [...] Fui me especializando em editoração eletrônica, até hoje algo que gosto de fazer. Nas horas vagas aprendi sobre topologia de redes, cabeamento, organização de diretórios, etc. O lado programador também melhorou. $[\ldots]$

Passei alguns anos trabalhando como enganador-high-tech até me decidir pela literatura. Escrevi onze livros, alguns best sellers na área técnica. [...] Nos últimos 5 anos me especializei em e-learning [...]. Hoje depois de 5 anos, acabou o tesão. [...]. Depois de muita contemplação, decidi investir meu know-how na Internet, mais precisamente nos blogs.

O objetivo era me tornar o primeiro blogueiro profissional do Brasil. Não desenvolvedorblogueiro, escritor-blogueiro, jornalista-blogueiro. Apenas blogueiro. Outras atividades que porventura apareçam complementarão os blogs, não o contrário. [...]"
\end{abstract}

Carlos Cardoso optou por abandonar seu emprego e tentar se tornar um "blogueiro profissional". Segundo Cardoso, "blogueiro profissional" é aquele(a) que consegue viver da renda de seus blogs. Ou seja, é o indivíduo que, antes de ser jornalista ou programador(a), é alguém que escreve para um dispositivo específico - blogs - sobre assuntos que são de seu interesse, recebendo, por isso, uma quantia em dinheiro proveniente de patrocinadores ${ }^{13}$. Nesse sentido, Cardoso tem por objetivo se tornar um "blogueiro profissional" e, para tanto, como podemos notar em seus posts, pretende conhecer a fundo os mecanismos que envolvem a criação e a manutenção de um blog, profissionalmente falando.

Outro ponto importante a ser salientado reside no fato de que a palavra "profissional" estaria ligada, ainda, ao sucesso em ambientes digitais; à conquista de um público que daria audiência para suas publicações. Com isso, o ato de fazer

\footnotetext{
${ }^{13}$ Uma das formas usadas por Carlos Cardoso foi o sistema AdSense do Google. O(A) blogueiro(a) coloca em seu blog links com propaganda e, toda vez que estes são clicados, recebe um valor estipulado pelo Google.
} 
posts para um blog seria coroado, tendo em vista que a chegada ao sucesso pressupõe a realização de algo, por sua vez, considerado profissional ${ }^{14}$.

A seção "Quem sou eu" revela características sobre gostos e interesses de Carlos Cardoso demonstrados ao longo de diferentes épocas. Esse estilo peculiar de descrever esses elementos nos permite inferir que o blogueiro assume uma persona geek. Por ser um indivíduo aficionado por tecnologia e ansioso para "descobrir" o funcionamento de aparelhos e demonstrar esse conhecimento, Cardoso parece saber como apresentar-se a fim de atrair indivíduos com interesses semelhantes. Nesse sentido, o uso de uma linguagem técnica, bem como referências e gírias próprias do grupo, acaba por selecionar e caracterizar o blogueiro e o grupo de seus(suas) seguidores(as) como geeks.

A partir da leitura dos dados em análise, percebemos algumas características que fazem de Carlos Cardoso um geek. Segundo McArthur (2009),

O geek é aquele que se torna expert em um assunto por meio de desejo e de motivação. [...] Ser geek é estar comprometido, estar interessado em um assunto, e então atuar nesse comprometimento. Geeks se aproximam com base em saberes comuns relacionados a um determinado assunto. Esses grupos vão se identificar como geeks de computação, geeks de animes, geeks de jogos, jogadores, hackers, e mais um número de outras identificações. Apesar da classificação, esses geeks compartilham a experiência de serem experts [...]. ${ }^{15}$ (MCARTHUR, 2009, p.62)

Nesse sentido, ao ostentar saberes, ao usar gírias, linguagens e referências culturais direcionadas para seus pares, Cardoso coloca-se como alguém disposto a manter uma atuação cara a geeks. Ou seja, a sua posição de destaque é negociada constantemente a partir de performances usadas por outros(as) geeks tanto em ambientes digitais quanto fora destes. Nesse sentido, o conhecimento é algo bastante apreciado dentro da cultura geek e aparece como uma alternativa para conquistar uma posição dentro do grupo e, por conseguinte, ser acolhido pelos(as) demais.

\footnotetext{
${ }^{14}$ Para maiores detalhes sobre fama e reconhecimento, veja o capítulo "Fama e Reconhecimento: sobre a noção de celebridade"

${ }^{15}$ Tradução livre da autora. No original: "The geek is one who becomes na expert on a topic by will and determination. [...] To be geek is to be engaged, to be enthralled in a topic, and then to act on that engagement. Geeks come together based on common expertise on a certain topic. These groups might identify themselves as computer geeks, anime geeks, trivia geeks, gamers, hackers and a number of other specific identifiers. Regardless os classification, these geeks share the experience of being experts [...]. (MCARTHUR, 2009, p. 63)"
} 
Ao analisarmos os dados coletados, podemos perceber que o conhecimento é uma forma de se destacar entre os(as) demais. Ao assumir-se como um(a) especialista, o indivíduo seria credenciado ao grupo e, hierarquicamente, poderia vir a ocupar um lugar de destaque. Nesse sentido, no circuito-blogue, o papel de destaque é negociado com base em valores simbólicos apreciados pela microcelebridade e por seus(suas) seguidores(as) naquele âmbito ${ }^{16}$. Ou seja, a mesma pessoa, ao estabelecer uma performance ou interações em outros circuitosblogue, atuará tal e qual se espera, seja como novato(a) ou veterano(a). No caso dos blogs em análise, existe o apreço à cultura geek e, por essa razão, as performances e interações estão voltadas para esse contexto.

A cultura geek, abordada por esse trabalho, está inserida no âmbito de diversos grupos interessados em compartilhar saberes relacionados, especialmente, à área de tecnologia da informação. Os geeks são constantemente descritos por meio de estereótipos, os quais apelam para alguém com uma personalidade reclusa e que está sempre estudando (KENDALL, 2000). Ainda, essa cultura compreende, ainda, o conjunto de pessoas interessadas em aprender e dominar um determinado assunto, seja em disciplinas como História, Física, Filosofia ou Matemática ou, ainda, no desenvolvimento de hobbies como colecionar revistas em quadrinhos, selos, programação de computadores, hacktivismo, por exemplo(KONZACK, 2006).

Originalmente, a palavra geek costumava ser referência para artistas que se apresentavam em shows de horrores. Suas apresentações eram compostas de atos repugnantes, como comer insetos e arrancar cabeças de animais com a boca (McARTHUR, 2009). Os artistas geeks atraíam audiências que duvidavam da autenticidade e da coragem para realizar tais atos ${ }^{17}$. Por essa razão, pessoas com hábitos questionáveis e que buscavam formas de entretenimento consideradas incomuns passaram a ser descritas como geeks. Dentre os hábitos incomuns: idolatrar hackers, passar horas trancado(a) em um quarto estudando mesmo quando não há alguma avaliação agendada e desenvolver interesses sobre jogos eletrônicos (KENDALL, 2000).

\footnotetext{
${ }^{16}$ Maiores detalhes sobre valores simbólicos em comunidades virtuais, veja SÁ (2006).

17 In: What's a geek? <http://www.gibberish.com/gazebo/articles/geek3.html>. Acesso em: 31/08/2012.
} 
A cultura geek possui várias referências dependendo de qual categoria o indivíduo se enquadre. Segundo Konzack (2006), existem geeks em várias áreas, se considerarmos que o(a) geek é alguém interessado(a) em expandir seus saberes em uma área de conhecimento. De acordo com McArthur (2009), os(as) geeks são aficcionados(as) pelas áreas de conhecimento que despertam seu interesse e, por essa razão, desenvolvem um certo fanatismo por essas temáticas. Esse fanatismo relaciona-se ao modo de demonstrar seus interesses, sempre mencionando detalhes minuciosos sobre seus gostos e descobertas. Em alguns casos, a "exclusividade" e o "pioneirismo" são atribuições que colocam o geek em uma posição de destaque em um grupo (McARTHUR, 2009). O sentido pejorativo do termo, relacionado a pessoas de hábitos incomuns, permaneceu como designação de pessoas que gostam de estudar e, na maioria dos casos, acabam por se tornarem autodidatas.

Em um sentido amplo, os geeks são pessoas interessadas em desenvolver habilidades e saberes relacionados a um interesse, seja esse de ordem cultural, como uma série de TV; seja esse de ordem técnica, como a programação de computadores. Portanto, uma mesma pessoa pode ser um geek de tecnologia, tendo desenvolvido habilidades técnicas para tal, ou, ainda ser um geek de séries de TV, buscando por todas informações possíveis relacionadas a uma série de TV, como Star Trek, por exemplo.

No caso de Cardoso, a cultura geek está contida no conjunto de gostos e interesses pessoais. Além disso, o esforço empreendido pelo blogueiro, a fim de demonstrar a profundidade e a confiabilidade de seus saberes, caracteriza suas performances, em ambientes digitais, como sendo comuns a outros grupos de geeks. Por conseguinte, as temáticas abordadas nesses espaços compreendem as áreas de tecnologia e de ficção-científica, assuntos bastante apreciados por geeks. Nesse sentido, ao dirigir-se de forma pejorativa, usando alcunhas como "salsinhas" ou "tards", Cardoso reforça a sua persona geek ao mesmo tempo em que o caracteriza perante os(as) visitantes dos blogs em análise. Esse reforço é proveniente da inclusão daqueles(as) que estariam em um nível de conhecimento tal e qual ao de Cardoso e, portanto, seriam capazes de interpretar suas performances dentro do conjunto de referências apreciadas pelo blogueiro e por sua "corte" de seguidores(as). 
Por conseguinte, a cultura geek para a qual Carlos Cardoso se dirige é formada de participantes aficcionados(as) por esses temas. Geralmente, essa participação complementa, concorda ou, ainda, tenta corrigir detalhes que passaram despercebidos nos posts. O idioma geek abordado por Cardoso é composto por referências sutis as quais somente os(as) iniciados(as) conseguem interpretar. Cabe ressaltar, ainda, que, independente de serem iniciados(as) ou não, o estilo peculiar com que Cardoso aborda tais assuntos é capaz de gerar debates exaltados.

Uma coisa que notamos, com relação às referências sutis, está presente no layout de 2012 do Blog do Cardoso. A citação faz parte de um diálogo do filme Indiana Jones e a Última Cruzada (1989) e está localizada ao lado do título do blog, logo ocupando um lugar de destaque. O referido filme é considerado um ícone para a cultura geek. Eis a frase: You've lost today, kid. But it doesn't mean you have to like it. ${ }^{18}$

Essa frase é uma das falas do personagem Fedora, um ladrão de tumbas, interpretado pelo ator Richard Young. A sutileza se remete ao fato de que não existem maiores descrições acerca da referência postada. Ou seja, quem é "iniciado(a)" identificará imediatamente. Notamos, ainda, que se trata de uma forma de assumir uma forma de saber e ser credenciado, imediatamente, como alguém capaz de fazer uma menção sutil e com um nível de conhecimento sobre uma obra-referência dentro da cultura geek. No Contraditorium também existe uma referência ao mesmo filme, na frase abaixo do título do blog: "Fortune and Glory, Kid. Fortune and Glory."

A popularidade de Carlos Cardoso foi construída ao longo de suas participações e performances em diversos ambientes da Web, como, por exemplo, os Bulletin Board Sytstems (BBSs). Os BBSs foram espaços bastante populares entre as décadas de 1970 e 1990 (CASTELLS, 2003). Esses sistemas eram usados por pessoas que, como Cardoso, eram entusiastas ou profissionais das áreas de informática e de tecnologia da informação. No post a seguir, o blogueiro relembra, com certo saudosismo, da época em que interagia nesses espaços.

"10 Sinais que você é um BBSeiro vivendo na internet", publicado no Blog do Cardoso em 01/01/2006

${ }^{18}$ Tradução: "Você perdeu hoje, filho. Mas isso não quer dizer que você tenha que gostar disso." 
(contagem regressiva para ser repassado como do veríssimo em 5, 4, 3...)

Nos formulários, na idade você tem que dar page down 3 vezes até chegar no seu ano

Você é o único que chama os desenhos com caracteres coloridos do Orkut de ANSI Art

Metade de seus amigos você só chama pelo nickname, mesmo ao vivo.

Desses, 2/3 você sequer lembra do nome verdadeiro

Nas listas de discussão você pergunta se ALLguém pode te ajudar

Você não reclama de threads que não acompanham o subject

Seu ICQ tem menos de 8 dígitos

Você já escreveu "eh", "pq" e "abcos" por necessidade, não modismo.

99\% das piadas do seu email você já recebeu antes. Em QWK.

Você sabe o que é QWK

Como podemos perceber, Carlos Cardoso tem participado de ambientes digitais, pelo menos, desde os anos 1990, considerando que os BBSs ainda eram populares naquela época (CASTELLS, 2003). Todavia, a popularidade e o sucesso em ambientes digitais foram alcançados a partir de seus blogs, especialmente o Blog do Cardoso, o Contraditorium e de sua coluna no blog MeioBit.

O Blog do Cardoso foi o primeiro a ser criado. O primeiro post data de 21/05/2005 e seu título é "Antipost". Antes de ampliar a sua atuação para outros ambientes digitais, Carlos Cardoso escrevia sobre diversos assuntos, englobando temas relacionados à cultura geek. Portanto, havia resenhas e tutoriais sobre o funcionamento de equipamentos e de tecnologias, relatos sobre séries e estórias de ficção científica, assim como curiosidades da Web (vídeos populares, memes e imagens). Havia, ainda, espaço para a publicação de assuntos polêmicos, como aqueles relacionados a religiões e à homossexualidade.

O blog Contraditorium foi o segundo a ser criado e surgiu em 2006. Inicialmente, o Contraditorium recebeu vários conteúdos já publicados no Blog do Cardoso. Os posts a seguir dão indícios de que Cardoso iria mudar o nome e o endereço do Blog do Cardoso e manteria somente o Contraditorium.

\section{“O Site Mudou”, publicado no Blog do Cardoso em 09/02/2006}

Este site Cresceu e Mudou. Estamos (olha o plural majéstático aí) migrando para um servidor próprio, separando as informaões úteis, tutoriais e curiosidades dos textos puramente pessoais, ou absolutamente fora da temática do site.

O novo domínio é o... http://news.contraditorium.com

O site está disponível via RSS, claro. Assim, atualize seu leitor.

Agradeço a todos que apareceram por aqui, seja via Google ou por indicação.

Também mudei o layout do site novo, para que certos chatos parassem de reclamar. 
Meu novo site está ficando bem mais flexível que este blog. Agora instalei um plugin de sitemap que lista tudo que já foi postado, de forma elegante e bonita.

Vejam como ficou legal, o mapa do Contraditorium!

Entretanto, o Contraditorium acabou desenvolvendo um estilo próprio e passou a ser um espaço para a publicação de textos com temáticas diversificadas. Essa diversidade é observada em posts nos quais Cardoso fala sobre política, curiosidades, celebridades e comportamento em uma linguagem cara à cultura geek. Além disso, notamos diversos posts explicativos sobre como se tornar um(a) blogueiro(a) profissional, com experiências e técnicas compartilhadas pelo próprio Cardoso.

O primeiro post em sua coluna no blog de tecnologia MeioBit foi publicado em 30/03/2006 com o título "Download de Séries não é Crime”. O MeioBit foi criado por Leonardo Faoro e Luiz Eduardo Nercolini em 2006 com o objetivo de publicar informações relacionadas à área de tecnologia da informação. Atualmente, além de sua coluna, Cardoso ocupa a posição de editor de conteúdo do blog.

Os posts de Cardoso no MeioBit são voltados para pesquisas e descobertas na área de tecnologia. Portanto, abrange, além da tecnologia da informação, astronáutica e astronomia, tecnologia e equipamentos bélicos.

Carlos Cardoso é conhecido por seu comportamento peculiar, no que concerne a suas participações e performances em ambientes digitais. Geralmente, Cardoso costuma se colocar, em seus posts, como alguém que dedicou um bom tempo de pesquisas para elaborar aqueles conteúdos. Por essa razão, os questionamentos levantados, sob o ponto de vista de Cardoso, deveriam levar em conta o que foi abordado nos posts. Em muitos de seus posts, podemos ver reações ásperas da parte de Cardoso com relação aos comentários deixados por seus(suas) seguidores(as).

Os blogs em que Cardoso possui conteúdo trazem elementos da cultura geek que podem dar margem a diversas interpretações. Nesse sentido, os comentários trazem a visão de outras pessoas sobre o mesmo assunto, representando o conjunto daqueles(as) que concordam, o conjunto daqueles(as) que discordam e, ainda, aqueles(as) que não possuem familiaridade com os tópicos abordados pelo 
blogueiro. Ainda assim, Cardoso desempenha o papel de microcelebridade, estabelecendo e mantendo o circuito-Cardoso e seu público. 


\section{Comunicação, Mediatização e Interação}

\subsection{Mediação e Mediatização no Circuito-Cardoso}

Conversas, discussões, trocas de informações realizadas em ambientes digitais podem ser estendidas para fora do universo de dispositivos da Web. No que diz respeito às interações observadas no âmbito das seções de comentários do Blog do Cardoso, do Contraditorium e do MeioBit, percebemos em boa parte dos casos que esses espaços fazem parte de um conjunto de ambientes articulados entre si, em que as performances parecem se adequar à dinâmica de ações destes espaços. Tal dinâmica se refere à série de papéis desempenhados por indivíduos, considerando como referência a questão dos papéis sociais, a partir da metáfora da encenação teatral, proposta por Goffman ${ }^{19}$ (2002). Esse conjunto de cenários compreende páginas de sites de redes sociais, listas de discussão e, ainda, encontros presenciais entre alguns(mas) comentaristas e microcelebridades mais próximas de Cardoso. Nesse sentido, as performances on-line e off-line acabam por complementar a constituição da microcelebridade. Por sua vez, o circuitoblogue emerge como uma forma de mediação entre interações, conteúdos e participantes de ambientes digitais, revelando, dentre outras coisas, comportamentos, papéis, hierarquias simbólicas, temáticas, linguagens. Para que possamos compreender a importância do circuito-blogue para a existência da microcelebridade, apresentaremos a seguir algumas noções acerca do conceito de mediação.

A partir dos dados observados, notamos uma série de táticas usadas por Carlos Cardoso na tentativa de chamar atenção para os blogs em análise. Dentro desta perspectiva, as performances de Cardoso e dos(as) comentaristas possibilitaram, conjuntamente, a sua ascensão ao posto de microcelebridade. Nesse sentido, a atuação do blogueiro fundamenta-se no conjunto de performances realizadas no circuito-blogue que, por sua vez, o legitimam com

\footnotetext{
${ }^{19}$ Um panorama sobre o conceito dos papéis sociais, dentro da perspectiva de Goffman (2002),
} será dado no capítulo "Os percursos da Microcelebridade". 
uma figura de destaque neste circuito. De certa forma, Carlos Cardoso se sobressai em razão de interações e performances resultantes de seu desempenho no âmbito dos ambientes digitais dos quais participa. Além disso, tais ações são reconhecidas e despertam o interesse de indivíduos que acessam os blogs em análise.

O circuito-blogue reúne informações que orientam comportamentos e interações em ambientes digitais. Esses ambientes digitais são dotados de peculiaridades, no que tange aos modos de participar e interagir com os(as) demais e os conteúdos disponibilizados nesses espaços. O compartilhamento de links, a realização de comentários e, até mesmo, a forma como se deve escrever um post são delineadas tacitamente por interações e performances observadas entre os(as) participantes. Dessa forma, o conjunto de interações e de performances que se formam em torno de um circuito-blogue demonstra como o grupo se comporta e como os papéis são desempenhados e articulados entre si. Por conseguinte, as mediações no circuito-blogue são determinadas pelas reações e interpretações referentes aos conteúdos disponibilizados nos ambientes digitais nos quais a microcelebridade e seus(suas) seguidores(as) atuam.

As seções de comentários dos blogs analisados (Blog do Cardoso, Contraditorium e MeioBit) compõem uma parcela do circuito-Cardoso. As performances observadas nesses espaços existem em razão da rede de trocas (links, visitas, comentários, etc.), do poder simbólico e do interesse de pessoas nas performances do blogueiro. Por meio dessas mediações é possível visualizar papéis, uma forma de hierarquia válida para aquele contexto, linguagens e comportamentos e, ainda, uma forma específica de apresentar-se ao grupo naquele âmbito. Isso se revela, também, como uma forma de enxergar o papel desempenhado por Carlos Cardoso nesse circuito. Por ocupar uma posição destacada, o blogueiro, de certa forma, fornece meios - publicação de posts - para que uma interação venha a ser gerada na seção de comentários de seus blogs.

Poderíamos falar em uma mediação performática no circuito-blogue, em que o interesse entre público e microcelebridade é mútuo. Ou seja, a microcelebridade busca manter-se em uma posição de destaque. Entretanto, a sua popularidade depende tanto dela e, principalmente, daqueles(as) que consentem que o papel desempenhado por essa figura é relevante. Por sua vez, as audiências têm interesse em acompanhar as performances da microcelebridade, por isso visitam 
e/ou comentam seus blogs e páginas em sites de redes sociais. Por essa razão, o circuito-blogue aparece como uma forma de legitimar a microcelebridade e suas audiências como tais no âmbito dos ambientes digitais dos quais participam e atuam (BRAGA, A.,2009).

Dessa forma, a noção de mediação precisa ser apresentada para que possamos compreender os mecanismos peculiares ao circuito-blogue, no que concerne às interações realizadas nesse âmbito. Segundo Martin-Barbero, as mediações são "[...] as articulações entre práticas de comunicação e movimentos sociais, para as diferentes temporalidades e para a pluralidade de matrizes culturais." (MARTIN-BARBERO, 1997, p. 258). Notamos, então, que as mediações são processos por meio dos quais referências culturais se tornam inteligíveis, passíveis de serem incorporadas pelos indivíduos. Ou seja, as mediações fundamentam-se nos apelos aos conhecimentos e saberes adquiridos por nós ao longo de nossas vidas para que possamos reconhecer uma determinada manifestação cultural, por exemplo.

No caso do circuito-blogue, os processos de mediação são suportados por interações e performances que compõem o próprio circuito. Essas interações e performances são determinadas pela temática que se discute nesse âmbito, pelos interesses dos(as) participantes, pelas microcelebridades e, por fim, pelo que agrega todos(as) envolvidos(as) em interações em um determinado circuitoblogue. Portanto, as mediações nesse circuito acompanham as limitações e as possibilidades tecnológicas disponibilizadas aos(às) participantes para suas ações. Além disso, essas mediações traduzem os modos pelos quais a abordagem das temáticas deve ser feita e como deve ser o comportamento dos(as) participantes no que tange a essa participação.

Segundo Martin-Barbero (1997), as mediações são processos importantes pois são responsáveis pelas diversas interpretações acerca de uma mesma performance. No âmbito das seções de comentários do Blog do Cardoso, do Contraditorium e do MeioBit, notamos interpretações distintas para um mesmo post. Isso acontece devido ao que a temática deste post representa no conjunto de referências culturais de cada indivíduo. Ou seja, o assunto abordado, bem como a linguagem usada, despertam diferentes interpretações, tendo em vista que o contexto no qual um determinado indivíduo se encontra inserido pode diferir dos(as) demais. Essa diferença contextual, que está relacionada às referências 
culturais (gostos, origens étnicas, faixa etária, classe social, etc.), interfere na visão de mundo desse indivíduo, especialmente quando este escreve um comentário nos blogs analisados.

O circuito-blogue, por sua vez, acaba por mediar essas visões de mundo. Em um sentido amplo, aqueles(as) que participam das interações realizadas nesse circuito se interessam pelo que ocorre nesse âmbito. Nesse sentido, os tipos de interações desencadeadas pelos conteúdos publicados despertam ou não o interesse de indivíduos com base na performance de Cardoso dentro das limitações de seu circuito-blogue. Por isso, o "circuito-Cardoso" reflete os gostos e interesses do público que interage e participa da seção de comentários dos blogs em análise.

Como apontou Martin-Barbero (1997), as mediações são promovidas para darem novos significados e novos usos a performances e a interações que existiam em um momento anterior à chegada de uma nova tecnologia, o que acontece em nosso caso. A cultura geek, refletida nos conteúdos de Carlos Cardoso, recebe outra abordagem e é adequada ao contexto em que o "circuito-Cardoso" é desenvolvido. Nesse sentido, o circuito-blogue promove as mediações, indicando tacitamente aos(às) participantes ações e comportamentos adequados àqueles ambientes digitais, assim como à temática abordada ${ }^{20}$. Por sua vez, com base nos objetos de nossa análise, as seções de comentários do Blog do Cardoso, do Contraditorium e do MeioBit revelam como as interações sociais adaptam-se a novas formas de tecnologia e como estas mediam os significados dentro do cenário demonstrado.

J.L Braga (2006) aponta que as interações sociais são adaptadas gradualmente para as tecnologias emergentes. Isso acontece até que uma dinâmica interacional se torne referência e seja associada a uma determinada tecnologia. No âmbito dos ambientes digitais, notamos, dentre outras coisas, o circuito-blogue nas mediações interacionais entre os(as) participantes desses ambientes. Entretanto, essa dinâmica passou - e tem passado - por sucessivas adaptações para que se explore as possibilidades interacionais entre os(as) participantes desse circuito.

\footnotetext{
20 As gírias, as referências a produtos culturais, o comportamento comum, etc. são alguns pontos que permitem que os(as) membros(as) do grupo reconheçam-se como parte do universo (geek) retratado nesses conteúdos publicados por Carlos Cardoso.
} 
A “mediatização", segundo J. L. Braga (2006), é um processo por meio do qual as interações sociais passam no instante em que nos adaptarmos a uma tecnologia emergente. Gradualmente, essas interações tornam-se padrões cujas possibilidades e limitações estão relacionados à tecnologia em questão. Por essa razão, tomamos como referência o conceito de "mediatização" proposto por J. L. Braga (2006) para ilustrar a questão do circuito-blogue no que tange a interações sociais em ambientes digitais.

J.L. Braga propõe que o processo de "mediatização" é um "[...] processo interacional em marcha acelerada para se tornar o processo 'de referência' - o que corresponde a dizer que não assumimos o processo como completado." (BRAGA, J.L, 2006, p.2). Podemos depreender dessa afirmação que a "mediatização" compreende as sucessivas adaptações sofridas por nós a fim de incorporar uma nova tecnologia - e os usos relacionados a ela - a nossas atividades cotidianas.

Com relação ao circuito-blogue, o processo de "mediatização" traduz as perspectivas com as quais nos deparamos até construirmos um ambiente no qual, além de usar a tecnologia de ambientes digitais, as interações entre os(as) participantes desses ambientes fosse facilitada. Nesse sentido, podemos dizer que o circuito-blogue somente realiza as mediações interacionais pois tem se tornado um processo de referência para interações em ambientes digitais. Entretanto, o circuito-blogue ainda é capaz de transformar-se a fim de manter o fluxo dessas interações.

O circuito-blogue pode ser retratado, portanto, como um processo de referência em construção, tendo em vista que é capaz de traduzir a dinâmica das interações realizadas em ambientes digitais.

\footnotetext{
Se com relação às mídias tradicionais, a interação mediada por computador tem muito a conquistar rumo à sua legitimação, no interior da própria Internet, por outro lado, há processos próprios, incipientes, de legitimação de seus conteúdos e autores/as. Nesse sentido, destacaria dois modos de obtenção de credibilidade, prestígio ou respeito na publicação de conteúdos no espaço digital: i) pelo número de visitantes e comentários registrado (legitimação pelo público); ii) pela incidência de citação do blog, através da listagem de links, em outros blogs de prestígio já reconhecido (legitimação pelos pares). (BRAGA, A., 2008a, p.156)
}

Em nosso caso, os dados analisados reúnem interações e performances que obedecem a uma lógica em que os papéis são demarcados, assim como as performances relacionadas a essas atuações. Nesse sentido, aquele(a) que é um(a) 
participante ativo(a) age de uma maneira diferente do que daquele(a) que comenta pela primeira vez naquele espaço (BRAGA, A., 2008a).

Por sua vez, a dinâmica interacional de um circuito-blogue é influenciada por outras formas de interação decorrentes de outras mídias e de outros espaços. Ou seja, não podemos falar que o circuito-blogue esteja isolado porque resulta de uma nova modalidade tecnológica de comunicação. Nesse sentido, muitas das interações e performances realizadas nesse contexto tem como referência ações relacionadas a mídias de massa.

Sob esta perspectiva, as interações continuam para além dos comentários, em trocas de e-mails e mensagens em sites de redes sociais, telefonemas e, ainda, em encontros pessoais. Adriana Braga descreve um processo chamado de "complementaridade das mídias", por meio do qual participantes de ambientes digitais usam outras mídias e formas de comunicação para interagir com os(as) demais membros(as) do grupo (BRAGA, A. 2008b). No que tange ao circuitoblogue, trata-se da associação de diferentes dispositivos no sentido de complementar a postagem de textos, fotos e conteúdos sonoros e audiovisuais e o compartilhamento de informações para os(as) participantes desse circuito. Adriana Braga exemplifica as inúmeras referências a outros dispositivos feitas no livro de visitas de um blog como: e-mails, fotografias e encontros presenciais. Nesse sentido, precisamos enfatizar que as interações originadas no circuito-blogue são complementadas por atividades que se estendem para fora dos ambientes digitais (BRAGA, A. 2008b). Sendo a Internet extensão e meio para interações e performances, ela é integrada às atividades cotidianas de indivíduos na forma de um complemento. Por conta disso, notamos um cuidado em delimitar as esferas do público e do privado, especialmente levando em consideração que os ambientes digitais - como as seções de comentários - contam com a participação de desconhecidos(as).

Sendo assim, a "complementaridade das mídias" proposta por Adriana Braga (2008b) interfere nos posicionamentos assumidos no contexto do circuitoblogue. A fim de manter uma imagem alinhada às propostas desse circuito, os(as) participantes adequam-se ao fluxo interacional e comunicam suas interpretações acerca das interações realizadas nesses ambientes digitais (BRAGA, A. 2008a). Por outro lado, a "complementaridade das mídias" ressalta a importância e a interferência entre as diferentes mídias, com o objetivo de mediar referências 
culturais, como linguagens, visões de mundo e performances aceitos coletivamente.

Até esse ponto, vimos possibilidades de mediações partindo de mídias e de indivíduos (MARTIN-BARBERO, 1997). Assim como tivemos contato com os processos de incorporações de novas tecnologias a nossas atividades cotidianas, por meio de interações até se tornar um processo de referência (BRAGA, J.L., 2006). Essas formas de mediação compreendem processos em que as mídias promovem seus conteúdos que, por sua vez, passam pelas leituras feitas pelos indivíduos, com base em suas experiências, para esses conteúdos. Todavia, precisamos considerar, ainda, o processo em que as diferentes mídias são influenciadas por interações e performances realizadas em um dado contexto.

Como vimos, as interações e performances realizadas por meio do circuitoblogue são influenciadas por outros suportes midiáticos. Essa influência possibilita a continuidade interacional e performática sem, portanto, serem construídas rupturas entre o que realizamos on-line e off-line. Fausto Neto (2008) propõe que as mídias estão interligadas e não somente influenciam, mas são influenciadas por todas as interações sociais processadas em uma sociedade. A esse processo, o autor denominou "midiatização".

[...] as mídias deixaram de ser apenas instrumentos a serviço da organização do processo de interação dos demais campos, e se converteram numa realidade mais complexa em torno da qual se constituiria uma nova ambiência, novas formas de vida, e interações sociais atravessadas por novas modalidades do "trabalho de sentido". Neste contexto, as mídias não só se afetam entre si, se inter-determinando, pelas manifestações de suas operações, mas também de outras práticas sociais, no âmago de seu próprio funcionamento. (FAUSTO NETO, 2008, p.92)

As tecnologias das mídias constituem o suporte no qual interações e performances se tornam possíveis em ambientes digitais. As performances consideradas apropriadas, as instituições e suas funções, as interações próprias a cada contexto são representados por meio de dispositivos que, por sua vez, não são capazes de determinar e impor essas representações unilateralmente. A "midiatização" leva em consideração o tempo, o espaço geográfico, as barreiras da língua, dentre outros fatores, como sendo elementos capazes de influenciar como as tecnologias serão apropriadas e, por conseguinte, como as interações suportadas por essa tecnologia da mídia serão realizadas (FAUSTO NETO, 2008). 
A "sociedade da midiatização", segundo Fausto Neto (2008), realiza um contraponto com a "sociedade dos meios". A "sociedade dos meios" é capaz de impor suas referências ideológicas e as suas condições, no sentido de organizar "um processo interacional e sobre o qual teriam uma autonomia relativa, face à existência dos demais campos.” (FAUSTO NETO, 2008, p. 93). Em contrapartida, a "sociedade da midiatização" depende das referências culturais que um indivíduo possui e, portanto, não se trata de um processo homogêneo.

Por outro lado, a "mediatização", na proposta de J.L. Braga (2006), decorre da flexibilidade que as interações sociais têm para adaptar-se a diferentes tecnologias e a contextos sociais distintos e, por conseguinte, se tornarem referência. $\mathrm{O}$ modo pelo qual um circuito-blogue é originado, no que concerne às interações predominantes, pode variar nos diversos grupos que atuam na Web. Entretanto, existem semelhanças no modo pelo qual o procedimento é realizado. A “mediatização", segundo J.L. Braga (2006), é o caminho percorrido para que uma interação social seja incorporada à dinâmica social e, assim, se torne um padrão aceito coletivamente.

A "midiatização" aparece enquanto são analisadas as trocas entre mídias e a sociedade como um todo. Os paradigmas e diretrizes orientados pelas mídias são recebidos pela sociedade de modos distintos. O modo pelo qual esses modelos serão incorporados pelos indivíduos a suas vidas pressupõe a conexão entre o seu background cultural e os papéis desempenhados por cada um desses indivíduos em sociedade. No caso do circuito-blogue, as formas de interagir, de fazer uma performance, bem como os(as) personagens assumidos(as) seguem dinâmicas moldadas pelos(as) participantes desse circuito. Uma das figuras principais, no que concerne à orientação dessa dinâmica, é o(a) blogueiro(a)/microcelebridade. A tradição do(a) blogueiro(a) no grupo

lhe dá um lugar de fala privilegiado, pronunciando-se oficialmente quando um conflito ameaça a extrapolar o propósito do grupo, mediando, ponderando e dando o tom adequado à interação, de modo a retomar a ordem. (BRAGA, A., 2009, p. 155)

Por essa razão, precisamos ressaltar que essa dinâmica variará de um circuito-blogue para outro, especialmente pelo fato de que depende do comportamento e da performance da figura de maior destaque: a microcelebridade. Nesse sentido, a "mediatização" preocupa-se mais com o 
processo posicionamento de interações sociais como referência, fundamentandose nas transformações tecnológicas e em como estas influenciam as interações sociais (BRAGA J.L., 2006). Portanto, a "mediatização" relaciona-se com os modos pelos quais o processo de incorporação será mediado e como este será incorporado.

A cultura geek retratada por Carlos Cardoso passa pela interpretação pessoal do blogueiro do que seja relevante para suas publicações. Ao trazer seu ponto de vista para seu circuito-blogue, Carlos Cardoso constrói, de certa forma, um enquadramento da cultura geek por meio das performances e interações realizadas no âmbito desse circuito. Sob esta perspectiva, observamos linguagens e códigos próprios desse grupo que, por sua vez, caracterizam tais ações. O "circuitoCardoso" realiza as mediações, tendo em vista que promove uma forma de sentido no conjunto das ações que se processam nesse contexto, por meio dos significados reunidos nas interações entre os(as) participantes e nas performances empreendidas por estes(as). Nesse sentido, podemos dizer que a cultura geek enquadrada por Carlos Cardoso é composta por diferentes visões, nas quais transparecem seus interesses e gostos pessoais, bem como a de seus(suas) comentaristas, dentro do contexto do circuito-Cardoso.

O circuito-blogue é determinado pelas interações e performances desenvolvidas entre os(as) participantes de ambientes digitais. Os interesses dessas pessoas motivaram os modos pelos quais o circuito-blogue tem sido organizado. Se mantivermos o pressuposto de que o circuito-blogue engloba temáticas e interesses semelhantes, será por meio desse circuito que as pessoas terão acesso e, consequentemente, conhecerão os processos reunidos sob essa dinâmica em particular.

No circuito-blogue, as pessoas se adequam a comportamentos, incorporam linguagens as quais, muitas vezes, são usadas somente naquele contexto. Por exemplo, abreviações e corruptelas evidenciados, a exemplo de outros blogs, em seções de comentários dos dados em análise. Por outro lado, quando não se adota a interação ou performance esperados, podemos falar que ruídos foram criados e, por essa razão, a interpretação dada ao post, por exemplo, pode vir a ser condenada. Essa condenação não é gerada somente pela crítica explícita, mas pela "exclusão" do(a) "forasteiro(a)" do debate. 
As pessoas que não se identificam com a dinâmica do circuito-Cardoso conseguem perceber, em um sentido geral, a existência desse pertencimento coletivo, na forma dos(as) defensores(as) das ideias do blogueiro. Entretanto, tais indivíduos não são capazes de fazer uma interpretação aceita nesse circuito empreendendo, inclusive, críticas com base em referências próprias e, quase sempre, distantes daquelas apreciadas pelos(as) seguidores(as). Assim, a mediação funciona como o mecanismo que reúne significados, mais ou menos amplos, obedecendo a critérios como: reconhecer-se como parte de um determinado grupo (de comentaristas dos blogs de Cardoso, por exemplo); reconhecer a existência dessa manifestação; discordar ou ignorar o grupo em questão.

No caso de Carlos Cardoso, suas informações expressam suas opiniões sobre fatos relacionados à cultura geek, de pessoas interessadas em dispositivos da tecnologia da informação; em alguns casos, o próprio blogueiro reforça os estereótipos existentes em torno do(a) geek. Isso acontece na publicação de materiais relacionados à temática de ficção científica, seriados, jogos, por exemplo. O estilo, caro ao blogueiro, caracteriza - e diferencia - a sua abordagem sobre esse universo, aproveitando, para tanto, os ambientes digitais dos quais participa.

No caso de microcelebridades como Carlos Cardoso, os processos de mediação podem ser considerados como os mecanismos que possibilitam assumir a sua posição como microcelebridade. Além disso, por meio de tais mecanismos, é possível manter-se relevante dando sentido e continuidade aos conteúdos dispostos no circuito-Cardoso. Podemos dizer que esses mecanismos compreendem técnicas, condizentes com os meios disponibilizados, usadas para alcançar visibilidade. Podemos citar como exemplo: visitar outros blogs e deixar comentários, cadastrar-se em sites dedicados a divulgar seu perfil como blogueiro 21 .

A "mediatização" é o processo pelo qual uma forma de interação social passa até que assuma a posição de referência. É o momento no qual uma interação social começa a ser apropriada pelas pessoas seguindo, portanto, o caminho para que seja incorporada majoritariamente por um grupo até se tornar parâmetro para interações semelhantes dentro de um dado contexto. Segundo J. L. Braga (2006),

\footnotetext{
${ }^{21}$ Para maiores detalhes, vide o capítulo "Os percursos da Microcelebridade".
} 
esse processo pode ser condicionado pelas mídias, por meio de mecanismos capazes de influenciar a adoção dessa interação no dia-a-dia.

Quando falamos em microcelebridades e circuito-blogue, devemos pensar nas diversas ações desenvolvidas nesse contexto. Primeiramente, um indivíduo cria um perfil público, na forma de um blog, por exemplo, desejando compartilhar sua opinião acerca dos mais variados assuntos. Quando esse indivíduo se torna popular, atraindo alguns(mas) milhares de seguidores(as), é capaz de chamar a atenção de outras pessoas, inclusive das mídias de massa. Essa atenção, de certa forma, orienta as ações do blogueiro(a)/twitteiro(a)/administrador(a) de páginas em sites de redes sociais, estabelecendo-se performances consideradas, de certa forma, como sendo referenciais.

Nesse sentido, a "mediatização" ocorre como uma forma de tornar uma interação "incorporável” por um número considerável de pessoas para que, enfim, se torne referência. Entretanto, J.L. Braga (2006) enfatiza que o processo não termina no momento no qual a interação social se torna emblemática. Por isso, podemos dizer que se trata de um processo que se adapta continuamente a transformações de ordem sociológica e de ordem tecnológica. De ordem sociológica, podemos falar em momentos de crises, como mudanças de paradigmas comportamentais em um blog, em que é preciso se adequar ao novo contexto. Já de ordem tecnológica, podemos colocar as constantes atualizações no campo da informática, em que precisamos aprender como lidar com os novos dispositivos e a incorporá-los em nossas vidas.

A mediação não está nas mãos exclusivamente de Cardoso, embora ele ocupe um papel de destaque no circuito-Cardoso. No circuito-blogue, o papel de destaque é ocupado por aquele(a) que recebe um fluxo maior de referências, como comentários em seu blog, menções em redes sociais, manifestações de aceitação ou, até mesmo, de repulsa. Assim, podemos falar na existência de um conjunto de pessoas que buscam manter esse destaque dado a Carlos Cardoso.

Para o blogueiro, a mediação é dada pelo circuito do qual ele próprio faz parte. Em razão de estabelecer um caminho para seu sucesso e, consequentemente, mantê-lo, Cardoso precisou buscar referências anteriores, observar as interações sociais predominantes no circuito e, por fim, inserir-se nessa dinâmica. Performances, como a publicação de comentários em posts de blogs, foram pouco a pouco adotadas e tornadas parte de padrões aceitos pelos(as) 
participantes do circuito-Cardoso. Essa adoção levou em conta as condições que o meio, no caso o blog, fornecia e em como isso poderia ser usado a favor das performances intencionadas para esse ambiente digital. Logo, o meio, como suporte, influencia e é influenciado por essas interações processadas no circuitoblogue.

Nesse sentido, podemos falar em mediações em circuitos-blogue. Quando Cardoso é reconhecido(a) como microcelebridade, por suas performances na Web, estabelece-se um circuito de trocas e de poder simbólico em torno de sua figura. $\mathrm{O}$ valor simbólico embutido em um circuito-blogue legitima o blogueiro como microcelebridade, posto que links preferidos, as sugestões de blogs, seus posts, bem como outras indicações, ganham importância perante os(as) demais participantes. Por sua vez, os comentários revelam mediações, sobre o que foi abordado por Cardoso, sob o ponto de vista do(a) comentarista.

Ao observar as seções de comentários do Blog do Cardoso, do Contraditorium e do MeioBit, percebemos como as mediações realizadas no âmbito do circuito-blogue de Cardoso são importantes. Assim como acontece em outros blogs, tais mediações interferem nos comportamentos de comentaristas e do próprio blogueiro. Paralelamente a esse reconhecimento, o circuito-Cardoso é formado com base em interações, interpretações, links, reações que, por sua vez, acabam por gerar novas interações, interpretações e assim sucessivamente.

\subsection{Os Percursos da Microcelebridade}

A microcelebridade é um fenômeno resultante da popularização do acesso à Web, em que, por meio de ambientes digitais, diversos grupos de pessoas publicam e trocam informações sobre assuntos de seu interesse. Nesse sentido, a microcelebridade acaba tornando-se uma figura de destaque por meio de sua performance e das interações que realiza em blogs, por exemplo. As interações e performances resultam de posts, do compartilhamento de fotos, links, vídeos ou de qualquer outro conteúdo multimídia, bem como do contato, originalmente on-line, entre microcelebridades e audiências. Consequentemente, as interações tornam-se complementares e acabam por determinar a composição de um circuito-blogue, como acontece no caso de Carlos Cardoso. 
Blogs e sites de redes sociais fornecem espaços para que indivíduos expressem suas opiniões sobre uma diversidade de temas (BRAGA, A. 2008a). Carlos Cardoso, por exemplo, constrói suas interações tendo como referência a cultura geek com a qual se identifica. Nesse sentido, o tipo de abordagem, a linguagem e o seu comportamento são, de certa forma, orientados com base nas referências existentes na cultura geek, sob o seu ponto de vista, dentre as quais, podemos citar séries e programas de TV, pesquisas e descobertas na área da tecnologia da informação e jogos. Por meio dessas interações, Carlos Cardoso adota uma forma de apresentação pública que, por conseguinte, será como seus(suas) seguidores(as) o reconhecerão no contexto de ambientes digitais.

Adriana Braga aponta que tanto blogs como sites de redes sociais funcionam como um espaço "para apresentações do self" (BRAGA, A. 2008a), em que indivíduos estabelecem uma imagem pública para aqueles(as) com os(as) quais interagem. A “apresentação do self” (BRAGA, A.,2008a) determina a persona digital e pública de um indivíduo, ou seja, os atributos que a microcelebridade e os(as) participantes de ambientes digitais usarão toda vez que precisarem se dirigir aos(às) demais nesse contexto. Ao assumir essa "persona", a microcelebridade preserva a sua intimidade ao mesmo tempo em que estabelece o quanto de si será compartilhado publicamente.

A linguagem cara aos(às) geeks do Blog do Cardoso, do Contraditorium e do MeioBit compreende jargões e gírias de: profissionais ligados à área de tecnologia da informação e da área de informática; gamers; falas e menções a atitudes de personagens de seriados de TV e de filmes, por exemplo. Essa forma peculiar de escrever e de se dirigir aos(às) participantes do circuito-Cardoso seleciona, de certa forma, o público dentre iniciados(as) e não-iniciados(as).

As referências e as citações, inseridas em posts e em comentários, revelam posições dentro do circuito-Cardoso, na medida em que notamos a existência de uma linguagem definidora da opinião e de posicionamentos assumidos por Cardoso em seus blogs. Sendo assim, os papéis são negociados constantemente, a fim de que performances se tornem verossímeis e, assim, os(as) participantes ganhem confiança entre si (BRAGA, A. 2008a).

As negociações apontadas por Adriana Braga (2008a) acabam por legitimar tais papéis com base nas interações desenvolvidas e que, por sua vez, dão credibilidade ao circuito-blogue. Tendo em vista que este circuito depende do 
conjunto de interações e performances realizadas em ambientes digitais ligados, de certa forma, pela similaridade entre temáticas abordadas, os(as) participantes são partes determinantes na continuidade do circuito-blogue. Por sua vez, podemos depreender que se trata de um processo coletivo, no qual a microcelebridade é um papel de destaque, mas não se encontra centralizado; não institui uma forma de poder exclusivo, mesmo que tenha instâncias de controle, como a moderação dos comentários publicados por exemplo.

As interações sociais implicam em ações envolvendo duas ou mais pessoas ligadas por uma diversidade de interesses, em nosso caso por gostos pessoais. Os(as) envolvidos(as) nessas interações são, de certa forma, impactados pelas consequências desses atos. Simmel (1983) conceitua a conexão entre indivíduos por meio de interações, dando o sentido para a unidade de um grupo, por meio da ideia de "sociação".

A sociação só começa a existir quando a coexistência isolada dos indivíduos adota formas determinadas de cooperação e de colaboração, que caem sob o conceito geral de interação. A sociação é, assim, a forma, realizada sob diversas maneiras, na qual os indivíduos constituem uma unidade dentro da qual realizam seus interesses. (SIMMEL, 1983, p. 60)

As performances realizadas no âmbito de um circuito-blogue dão unidade ao grupo, ainda que este grupo seja heterogêneo. No caso do circuito-Cardoso, as técnicas usadas pelo blogueiro, a fim de elevar a quantidade de visitantes para seus blogs, acaba por atrair pessoas que gostam de suas performances e indivíduos que discordam totalmente de suas considerações. Entretanto, apesar dessa diversidade, os papéis desempenhados por cada um(a) determinam a existência de uma espécie de instituição digital - circuito-blogue - que, por sua vez, reúne essas pessoas por conta da posição destacada de Cardoso.

Como Simmel (1983) aponta, a cooperação e a colaboração de indivíduos resulta em formas interacionais interdependentes, as quais fornecem um sentido que une, em certo aspecto, o grupo. Desse modo, os eventuais conflitos no grupo acabam por reforçar esse sentido, tendo em vista que, se esse pensamento se mantiver, os(as) membros(as) do grupo atuarão em defesa da preservação do sentido que os une (SIMMEL, 1983). As discussões acaloradas, nas seções de comentários do Blog do Cardoso, do Contraditorium e do MeioBit, revelam aspectos do conceito de "sociação", como podemos perceber a seguir: 
Encontrada falha grave de segurança no Linux - Ainda sem correção, publicado no MeioBit em 13/02/2008

Gilson Silva 5 anos atrás

Cardoso, apesar das ironias ofensivas, tenho que reconhecer, e tal vez até fazendo uso da mesm a forma de escrita: você é um fogueteiro frustado, pois comemora o que já não é.

[...]Pensei que você sabia disto. Pelo menos o Freetard aqui sabe.[...]

Conquistador $\rightarrow$ Gilson Silva $\bullet 5$ anos atrás

$\mathrm{O}$ termo freetard que ele usou está correto, pois se refere somente àqueles que negariam o bug. Porém, a forma que ele escreveu dá a impressão de que todo usuário Linux é um freetard, o que não é verdade.[...]

Carlos Cardoso $\rightarrow$ Conquistador $\bullet 5$ anos atrás

Longe disso, os que efetivamente desenvolvem o Linux não são freetards, $99 \%$ dos usuários corporativos não é, muito menos o Linus em si.

O motivo da revolta é que QUALQUER bug ou problema em Windows ou Mac gera um monte de mensagens na caixa de sugestões de matérias no MeioBit, mas NENHUM bug de linux é enviado, os freetards ADORAM fingir que esses bugs não existem.[...]

Danilo Moneró Almeida $\rightarrow$ Carlos Cardoso $\bullet 5$ anos atrás

[...]Pode falar o que vc quiser cardoso mas desta vez te pegaram com a calça na mão. manacker $\rightarrow$ Carlos Cardoso $\bullet 5$ anos atrás

CC disse "O motivo da revolta é que QUALQUER bug ou problema em Windows ou Mac gera um monte de mensagens na caixa de sugestões de matérias no MeioBit, mas NENHUM bug de linux é enviado, os freetards ADORAM fingir que esses bugs não existem."

Não é contraditório voce dizer isso depois que um "freetard" informa-o de que já há correção? Se enviam a correção, o bug foi assumido, se enviam a correção é obvio que não deram uma de avestruz. Diga-se de passagem, essa coisa de avestruz esconder a cabeça é coisa de desenho animado, já diria um certo padre "isso non ecxsist!".

ruanfigueiredo $\rightarrow$ Carlos Cardoso $\bullet 5$ anos atrás

Ja parou pra pensar que o Meiobit nao eh o lugar preferido dos usuarios Linux?

Eles ja tem o br-linux de sobra pra isso[...]

Fabião $\rightarrow$ Carlos Cardoso $\bullet 5$ anos atrás

"Major Linux security hole found" você não entendeu?

Eles têm dificuldade com o 'hole'. É complicado saber sem nunca ter visto um.[...]

Gilson Silva $\rightarrow$ Fabião $\bullet 5$ anos atrás

Olá Fabio.

Para um mal intencionado, teu comentário tem duplo sentido. Não penso deste jeito, mas algum "fanboy" poderia dizer:

"Claro que nunca vimos um. Como um SO tão quase perfeito como o Jupiterix Mega Hiperbólico teria um hole ?"

Não penso desta forma, mas "a bola foi deixada quicando", e alguem poderia a ter chutado.[...]

As rotulações feitas por comentaristas, assim como pelo próprio Cardoso, definem, de forma objetiva, os papéis desempenhados por cada um(a) no circuitoCardoso. Consequentemente, essas caracterizações de participantes reforçam o sentido do grupo, tendo em vista que segregam aqueles(as) que estão fora das qualidades aceitas coletivamente e, ainda, mostram as diretrizes norteadoras desse circuito-blogue. Além disso, os conflitos internos servem para defender posicionamentos e, por conseguinte, legitimá-los coletivamente.

A definição de papéis no circuito-Cardoso tem por objetivo instituir diretrizes que serão, segundo o blogueiro, adequadas para as seções de 
comentários dos blogs em análise. Sendo assim, percebemos a existência de uma "etiqueta comum", inspirada nas formas de "mediatização" (BRAGA, J.L., 2006) para seções de comentários. Entretanto, as personas digitais de comentaristas dos blogs de Cardoso dão um caráter próprio a estes espaços e são determinadas, justamente, pelas diretrizes instituídas que designam aqueles(as) que são bemvistos(as) no grupo ou não. Ao criar essas personas, os(as) comentaristas habilitam-se para interações e performances nesses espaços, definindo sua posição para esses ambientes. Isso pode ser explicado por meio do conceito de "sociabilidade" proposto por Simmel:

[...] as condições e os resultados do processo de sociabilidade são exclusivamente as pessoas que se encontram em uma reunião social. Seu caráter é determinado por qualidades pessoais tais como amabilidade, refinamento, cordialidade e muitas outras fontes de atração. Mas exatamente porque tudo depende de suas personalidades, não é permitido aos participantes realçá-las de maneira demasiado evidente. Quando interesses específicos (em cooperação ou conflito) determinam a forma social, são estes interesses que impedem o indivíduo de exibir sua peculiaridade e singularidade de modo ilimitado e independente. (SIMMEL, 1983, p. 170)

Por essa razão, os(as) comentaristas seguem regras, mesmo que tácitas, para participarem e interagirem no circuito-Cardoso. O próprio blogueiro, em algumas ocasiões, faz questão de realizar esse controle, como forma de manter a boa convivência entre os(as) participantes das seções de comentários, como podemos ver a seguir:

Igreja Universal rouba até da Apple, publicado no Contraditorium em 22/04/2006 Cardoso 327 semanas atrás

PQP. Tá certo que religião é sinônimo de ignorância, mas será que pelo menos UM dos crentes poderia escrever uma mensagem INTEIRA sem um erro de português?

"AGRADEÇO A DEUS E DEPOIS A IGREJA POR TER MIM AJUDADO"

OK, você deixou seu cérebro na porta. Mas podia ter pedido pra ficar ao menos com a área de gramática, não?[...]

Hórus Navajo. 319 semanas atrás

Pelo que percebi, quem frequenta a universal não sabe escrever mesmo, além do dinheiro, perdem a inteligência.[...]

Notamos que a criação de "apelidos", as reprimendas, assim como a personalidade autoritária de Cardoso, são determinantes para a caracterização de performances em seu circuito-blogue, assim como nos permite dizer que estes(as) participantes constituem um grupo com uma cultura própria, ainda que presente somente em ambientes digitais. 
Igualmente, percebemos que o conceito de "sociabilidade" guarda semelhanças com a ideia de "fachada x bastidores" proposta por Goffman (2002). Goffman (2002) fundamentou as interações sociais usando como metáfora o ambiente teatral, por meio da divisão entre fachada, plateia e bastidores. Por meio dessa estrutura, as "apresentações do self" poderiam ser analisadas tendo por base o interesse em torná-las efetivas perante aqueles(as) que não estariam envolvidos(as) na "produção" dessa encenação.

No circuito-blogue, podemos notar a evidência da microcelebridade como detentora de uma posição de destaque no grupo. Em seus "ambientes", a responsabilidade de produzir conteúdo é sua, bem como a administração desses espaços, tratando de excluir manifestações consideradas inadequadas. A inadequação se deve ao fato de que, por exemplo, algum comentário ou tentativa de interação pode romper os limites do que seja considerado ideal. Seja um comentário considerado invasivo, seja uma manifestação que estimule a presença de SPAM's, por exemplo.

A microcelebridade precisa estabelecer limites a si mesma de como e quando será preciso interagir com as suas audiências. Além disso, a microcelebridade necessita antever que interações serão feitas e como elas devem ser processadas a seu favor. Em nossa análise, notamos diversos momentos nos quais Cardoso se manifesta, por meio de comentários, ora de forma polida, ora de forma agressiva. Diante disso, podemos falar que a persona digital de Cardoso adapta-se ao tipo de comportamento esperado por sua audiência, como forma de legitimar sua posição destacada e dar credibilidade a sua performance.

Em seu circuito-blogue, Cardoso adota uma postura considerada transparente, evidenciando algumas técnicas usadas para atrair visitantes, bem como o trabalho árduo para elaborar seus posts. Percebemos uma estratégia definidora de como será sua abordagem, assim como sua persona digital deverá ser conhecida nos ambientes digitais. O comentário a seguir mostra o retorno do "gerenciamento de impressões" (GOFFMAN, 2002) de Cardoso, enfatizando características de sua persona digital.

“Godspeed, Discovery”, publicado no MeioBit, em 23.02.2011

Paul Paralelo $\rightarrow$ Carlos Cardoso . 2 anos atrás @Carlos Cardoso, 
O cara não é um chato. É um leitor do Meiobit, foi educado (ao contrário de você) e só quis ajudar. Você deveria, no mínimo, agradecê-lo pelo aviso da conta errônea.

Até curto alguns textos que você escreve (que não são tão maravilhosos quanto você acha), mas seria muito melhor para todos (leitores e para o Meiobit) se você tirasse essa sua fantasia de House. Pô, imagino que você tenha mais de 25 anos (talvez até mais de 30, pelas coisas que você cita que presenciou) e acho MUITO estranho sua atitude em relação aos LEITORES. Sem eles, cara, um blog seria apenas um diário, tipo aqueles de menininhas.

Curto MUITO o Meiobit (não comento muito, mas leio o leio sempre), mas hoje há vários "concorrentes" com a mesma qualidade, onde os leitores (não-trolls) são tratados dignamente. Reparei que o número de comentário nos "concorrentes" é muito maior do que os daqui. Será que isso não é reflexo dessa sua arrogância? Compare sua maneira de lidar com os leitores com a dos outros contribuintes do blog (inclusive a do dono, o Leo, que é SUPER educado).

Não me leve a mal, mas isso denota falta de educação de sua parte, literalmente.

Essa é uma crítica construtiva! Acredite!

ps. Fique à vontade para usar uma das suas duas técnicas favoritas aqui (infantis, desculpe): banir que reclama ou dizer que "a porta da rua é serventia da casa". Apenas lembre-se que há outras casas por ai...

Como podemos perceber, o comentarista realiza uma descrição de performances pelas quais Cardoso acabou se tornando conhecido. A simples colocação do comentarista demonstra que essas características se tornaram emblemáticas para suas performances on-line.

Interações sociais resultam das diversas interpretações de ações de um indivíduo em relação a outro, a fim de que se possa reagir de uma forma condizente com a interação processada. A este processo, Blumer denominou “interacionismo simbólico” (BLUMER, 1998)

[O interacionismo simbólico] vê o significado como emergente do processo de interação entre pessoas. O significado de uma coisa para uma pessoa surge a partir dos modos pelos quais os outros agem em direção à pessoa relacionada à coisa. Assim, o interacionismo simbólico vê os significados como produtos sociais, como criações que são formadas dentro e pode meio de atividades definidoras das pessoas enquanto elas interagem. ${ }^{22}$ (BLUMER, 1998, pp. 4-5)

Segundo Blumer (1998), os(as) envolvidos(as) em uma interação precisam estar cientes de que suas ações interferem no andamento da atividade em questão, constituindo uma ação integrada em prol do sucesso dessa performance. Dessa forma, o "interacionismo simbólico" é composto tanto pelos elementos introduzidos na interação quanto pelas referências existentes que, por sua vez,

22 Tradução livre da autora. No original: "[Symbolic interactionism] sees meaning as arising in the process of interaction between people. The meaning of a thing for a person grows out of the ways in which other persons act toward the person with regard to the thing. Their actions operate to define the thing for the person. Thus, symbolic interactionism sees meanings as social products, as creations that are formed in and through the defining activities of people as they interact." 
possibilitaram o seu acontecimento. Compreende, portanto, o conjunto de ações que, na forma interacional, são esperadas em um dado contexto pelos(as) envolvidos(as) nessas atividades.

Sob a perspectiva do "interacionismo simbólico", o circuito-blogue compõe as referências que dão legitimidade à performance de uma microcelebridade. $\mathrm{O}$ circuito-blogue, por meio da reunião de performances e de interações, dá ciência aos(às) participantes de como Cardoso se comporta e como é esperado que suas audiências se comportem. Além disso, por meio de experiências vivenciadas nesse âmbito, é possível antever comportamentos e manifestações com base no tipo de assunto abordado e, também, na performance desempenhada tanto por Cardoso quanto por seus(suas) comentaristas.

A visibilidade do circuito-blogue e a obtenção de popularidade pela microcelebridade é uma relação de via dupla. À medida que o circuito-blogue começa a existir, a microcelebridade em ascensão define suas diretrizes e suas audiências. Uma vez que se tenha público, consegue-se visibilidade e, por conseguinte, as performances se tornam populares e reconhecidas por um número maior de pessoas. Nesse sentido, o conjunto dessas ações legitima a microcelebridade.

Segundo o "interacionismo simbólico" de Blumer (1998), os objetivos da interação devem ser claros, a fim de que os(as) envolvidos(as) não ajam fora do contexto esperado. Sob esta perspectiva, este momento em particular define os limites, os significados e os objetivos envolvidos em uma interação, como ocorre entre microcelebridades, demais interagentes e circuito-blogue. Nesse sentido, Blumer (1998) discorre sobre a noção de "ação conjunta" que congrega todos os elementos envolvidos em uma dada interação, como pessoas, ambientes e referências àquela atividade. Tais elementos podem estar diretamente ou não relacionados aos(às) personagens principais desta interação mas, de certa forma, acabam por influenciar o resultado.

[Ação conjunta] se refere a mais ampla forma coletiva de ação que é constituída por arranjar em conjunto os comportamentos de cada participante individualmente. [...] A ação conjunta vai desde uma simples colaboração de dois indivíduos até o complexo alinhamento de grandes organizações e instituições ${ }^{23}$. (BLUMER, 1998, p. 70)

\footnotetext{
${ }^{23}$ Tradução livre da autora: "It refers to the larger collective form of action that is constituted by the fitting together of the lines of behavior of the separate participants. [...] Joint actions range
} 
A "ação conjunta", segundo Blumer (1998), evidencia o sentido coletivo das ações voltadas para uma interação. No âmbito do circuito-blogue, as performances são pensadas para ambientes digitais, com base em um conjunto de regras de participação, tendo como ponto de partida o comportamento das personas digitais que interagem nesses espaços. Ou seja, a "ação conjunta" delimita o alcance de determinadas interações, de modo que os(as) envolvidos(as) precisam saber o que acontece dentro das perspectivas designadas para um dado contexto.

Nesse sentido, o circuito-blogue reúne elementos integradores a fim de que objetivos coletivos - definidos por Cardoso e complementados por seus(suas) audiências - sejam alcançados por meio de ações esperadas para cada tipo de interação.

A interação no circuito-blogue obedece a uma etiqueta, na qual as pessoas adaptam suas atitudes e seus comportamentos a fim de participarem da interação (BRAGA, A., 2008a). Essa etiqueta é composta pelas interações registradas e tidas como referência, por sua popularidade, em um circuito-blogue. Ou seja, se uma abordagem feita por um indivíduo em uma seção de comentários de um blog resultou em várias respostas, ela será usada como referência, por exemplo, por aquele(a) que acabou de chegar àquele espaço interacional.

\begin{abstract}
Existe uma espécie de hierarquização que se manifesta, por exemplo, no retorno dado a uma crítica no contexto do LV, que pode ir do ostracismo, ironia ou agressão até uma justificativa respeitosa acerca do ponto criticado. No primeiro caso, quando a crítica parte de uma visitante anônima os desconhecida, e no segundo, quando parte de alguma visitante prestigiosa da blogosfera. (BRAGA, A., 2008a, p. 74)
\end{abstract}

Expandindo a questão de "ação conjunta", chegamos as "apresentações do self" nos ambientes digitais (BRAGA, A., 2008a). Notamos, nos dados analisados, o interesse em especificar um conjunto de referências e diretrizes que norteiam não só os posts de Cardoso, mas as participações de seus(suas) comentaristas. Ao definir esses aspectos, percebemos a emergência de uma forma discursiva na qual Cardoso atua como enunciador de uma "fala". A elaboração de um discurso já define, propriamente, o que será tratado e quais serão os elementos a serem usados para se alcançar o sucesso da performance. 
As interações processadas no âmbito do circuito-blogue compreendem uma multiplicidade de dados e de informações disponibilizados por seus participantes. Tais interações contribuem para que o nome da microcelebridade receba cada vez mais atenção no circuito. O número de visitantes diários, a quantidade de comentários, o volume de menções que o nome da microcelebridade tem podem constituir parâmetros para ao recebimento de convites das chamadas mídias de massa, interessadas em expandir sua atuação e aproveitar o público existente em torno dessas pessoas.

Como vimos, o circuito-blogue é composto por uma série de performances e de interações que, por sua vez, determinam a relevância de uma microcelebridade neste contexto. Ao observar as seções de comentários do Blog do Cardoso, do Contraditorium e do MeioBit, percebemos a existência de um conjunto de referências a que se deve recorrer para iniciar uma performance ou uma interação. Essas referências são usadas tanto pelo blogueiro/microcelebridade quanto por aqueles(as) que visitam e comentam os posts em seus blogs. Por esse motivo, podemos falar em mediações, especialmente se levarmos em conta as diversas interpretações, reações e performances observadas em um circuito-blogue. Embora seja possível notar um sentido de grupo (BRAGA, A. 2009), o circuitoblogue engloba, ainda, visões de mundo diferentes acerca de um mesmo assunto. Por conseguinte, as pessoas que participam e interagem nesses ambientes costumam usar performances e interações anteriores como referências para o comportamento a ser desempenhado.

Uma forma de valorar a popularidade de uma microcelebridade é por meio da quantidade de comentários deixada em seus blogs. O comentário significa, para os(as) visitantes, que alguém reagiu e decidiu compartilhar as suas considerações sobre o post. Portanto, se existe um número elevado de comentários significa que o blog - e o(a) blogueiro(a) - é popular. Entretanto, precisamos ressaltar que conseguir um comentário para um post é uma tarefa complexa, que requer do(a) blogueiro(a) a construção de uma visibilidade e a atuação em circuitos-blogue de microcelebridades já consagradas.

Adriana Braga aponta que os comentários deixados em blogs fundamentamse em elogios ou críticas, sugestões de conteúdos, links para os próprios espaços e, ainda, a publicação da opinião do(a) comentarista sobre o que se encontra nesses espaços (BRAGA, A. 2008a). Sob esse aspecto, a seção de comentários faz parte 
do circuito-blogue, tendo em vista que as interações processadas nesse espaço são determinadas pelo interesse em conteúdos disponibilizados por microcelebridades e por seus pares.

Nesse sentido, a dinâmica da seção de comentários é complementada por outras formas de interação. Ou seja, um comentário publicado naquele espaço pode ser linkado e discutido em outros ambientes digitais. Além disso, esse comentário pode levar à produção de outros conteúdos e, com isso, amplificar a mensagem embutida no conteúdo que serviu, inicialmente, como referência.

Carlos Cardoso pavimentou sua estrada de sucesso na Web escrevendo sobre tecnologia. Suas postagens no Blog do Cardoso, no Contraditorium e o MeioBit abordam temas que interessam o blogueiro e isso fica evidenciado claramente em alguns de seus posts, como vimos na seção "Quem sou Eu", publicada inicialmente no Blog do Cardoso. Os interesses e gostos pessoais de Cardoso são revelados na seção "Quem sou eu" de seus blogs e em diversos posts. Além disso, o blogueiro insiste em detalhar características por meio das quais gostaria de ser conhecido e como o seu público deverá denominar, inclusive, o conteúdo de seus blogs.

Cardoso 2.0 - Mudança Geral - Agora é tudo pelo social, publicado no Contraditorium em 19/05/2008

Não é segredo de ninguém que eu não dou bola pra mídias sociais, orkut, twitter, essas frescuras. Eu sou a única criatura do planeta que tem a cara de pau de ter conta no Twitter, escrever mensagens, aceitar seguidores mas não seguir ninguém. [...] Isso, claro, acabou criando uma postura elitista de minha parte, que é divertido em mesas de bar, mas na prática aliena leitores. E o que a Internet menos precisa são mais leitores alienados.

Portanto, estou deixando meu lado J.D. Salinger e me abrindo (no bom sentido) para o social. Vou passar a seguir gente no Twitter, estou com um perfil no Orkut, páginas no MySpace, Facebook e até criei uma lista de discussão para os leitores de meus blogs. Ao pessoal do projeto do Interney, aguardem e confiem.

Nesse trecho, percebemos que Cardoso reconhece sua "postura elitista" e tem um momento mea culpa que, ao mesmo tempo, acaba por reforçar a sua posição de destaque dentro do grupo. Ou seja, com essa atitude, Cardoso valoriza sua performance, tendo em vista que as pessoas que ele acompanhará, em ambientes digitais, serão privilegiadas por receberem sua atenção.

Uma das características mais marcantes, observadas nas seções de comentários dos blogs de Cardoso analisados, refere-se ao modo peculiar com que 
o blogueiro faz humor. Os exemplos evidenciam como Cardoso é conhecido, neste quesito, pelos(as) comentaristas.

Bangladesh não tem conserto, publicado no Blog do Cardoso em 02/03/2009

Wladimir Silveira. 204 weeks ago

Achei de mal gosto a forma como se refere a bangladesh, não sou de lá nem conheço ninguem que mora por lá, mas mesmo assim, achei que faltou respeito na forma como se dirigiu as pessoas que moram lá!

assino o feed do site ha um tempo e leio com frequencia, nunca vi nada igual, mas desta vez achei que faltou respeito...

Cardoso. 204 weeks ago

Mau gosto é Morar em Bangladesh, isso sim.

Beatrix. 204 weeks ago

É difícil ter respeito com quem não se dá o mínimo de respeito

"Produtos de bangladesh, agora com menos ratos" é um bom começo, mas só isso também.

Se duvidar agora vão pegar a rataiada e fazer um sopão

Como podemos notar, seus posts apelam para um sarcasmo peculiar e, por conseguinte, muitos(as) comentaristas acabam por discordar dessa forma de abordar determinado assunto. Além disso, os sarcasmos, as ironias e as piadas internas parecem revelar o interesse em abordar assuntos polêmicos sob abordagens consideradas pouco ortodoxas. Uma vez que consiga imprimir a si mesmo um "rótulo" - a persona digital - e que este atraia audiências, Cardoso garante a sua posição destacada e constrói a sua fama na Web. Nesse sentido, as performances e interações refletem o cuidado tomado por Cardoso para tornar-se um "blogueiro-profissional" 24 , demonstrando o controle e a posição estratégica que possui em seu circuito-blogue.

\footnotetext{
O caráter regulador da interação será exercido pelo tato, pelo traquejo, que através da amabilidade e cordialidade vai traçar os limites quando ocorrerem excessos. Não participam aqui diretamente quaisquer atributos mais objetivos que os/as participantes possuam, como riqueza, posição social, fama, cultura, bem como o caráter, a disposição pessoal, devem ser colocados em segundo plano como elementos desse ambiente de interação [...], exceto cumprindo um papel de meros matizes. (BRAGA, A. 2008a, p. 72)
}

O circuito-Cardoso constitui um fator determinante para a sua visibilidade em ambientes digitais. Em contrapartida, a performance do blogueiro nesses espaços foi responsável pela composição desse circuito e, por conseguinte, por sua legitimação. O "gerenciamento de impressões" (GOFFMAN, 2002), a apresentação do self (BRAGA, A., 2008a), as "ações conjuntas" e o "interacionismo simbólico" foram características observadas nas interações entre 
Cardoso e suas audiências. Assim como a noção de "sociação" e de "sociabilidade" (SIMMEL, 1983), esses elementos contribuem para que a microcelebridade ocupe um papel destacado e, assim, possa realizar performances que, de certa forma, determinam diretrizes performáticas nos ambientes digitais que gerencia. Nesse sentido, podemos falar na existência de um discurso que merece ser analisado. $\mathrm{O}$ enunciador-Cardoso se dirige a seu público, assumindo uma postura que dá entonação a suas ideias e opiniões. Os(as) comentaristas são co-enunciadores, pois interpretam essa mensagem sob seu entendimento, que pode ser favorável ou não ao blogueiro. Assim, em um sentido amplo, o contexto legitima tais ações, com base em referências e gostos pessoais, no ambiente em que as interações e performances são realizadas, bem como os outros discursos que sustentam o papel de destaque ocupado por Cardoso.

$* * * * * *$

Na próxima seção, descreveremos as questões metodológicas que nortearam a realização dessa pesquisa. Para a interpretação dos dados analisados, usamos como referência o método de Análise do Discurso. Por conseguinte, as performances de Cardoso, assim como aquelas empreendidas por seus(suas) comentaristas, são consideradas como parte de discursos nos quais são estabelecidos papéis dentro de encenações nos ambientes analisados.

${ }^{24}$ Para maiores detalhes, veja o capítulo "Carlos Cardoso, seus blogs e a Cultura Geek". 


\section{Metodologia}

\subsection{Análise do Discurso}

As seções de comentários do Blog do Cardoso, do Contraditorium e do MeioBit reúnem características interessantes a respeito da composição da persona digital de Carlos Cardoso. Tanto seus posts quanto os comentários publicados demonstram como o blogueiro legitima-se como uma figura de destaque em seu circuito-blogue. Para observarmos as práticas sociais usadas por Cardoso e por seus(suas) comentaristas, adotamos como base metodológica a Análise do Discurso (AD), especialmente sob a perspectiva dos autores Dominique Maingueneau (1997; 2004) e de Michel Foucault (2010). Nesse sentido, usamos como referência os seguintes conceitos: a noção de comentário (FOUCAULT, 2010), de enunciado (MAINGUENEAU, 1997), de enunciador (MAINGUENEAU, 1997, 2004), de co-enunciador (MAINGUENEAU, 2004) e de contexto (MAINGUENEAU, 2004).

Blogs são espaços de interação em ambientes digitais, nos quais, por meio de sucessivas atualizações de conteúdos, visitantes podem publicar considerações sobre posts e trocar informações de toda sorte com os(as) demais (BRAGA, A., 2009). As considerações publicadas em seções de comentários podem revelar como comentaristas enxergam o(a) autor(a) do post, interferindo, portanto, na legitimidade de uma microcelebridade (BRAGA, A., 2008a). Na medida em que percebe-se uma hierarquia simbólica entre os(as) participantes do circuitoCardoso, a AD parece auxiliar na compreensão da importância dos papéis desempenhados por visitantes, microcelebridades e por Cardoso no âmbito de seu circuito-blogue.

Os comentários constituem um dos parâmetros para determinar a popularidade de uma pessoa em ambientes digitais. Tais manifestações são o "lado público" da quantificação de participações em blogs, tendo em vista que o número de visitantes permanece restrito ao(à) administrador(a), quando o blog não 
possui um contador de visitas embutido no layout do blog. Logo, maior número de comentários determina que, numericamente, o(a) blogueiro(a) é uma figura popular. A sua popularidade resulta, como vimos, de uma série de fatores que determinam a existência de um circuito-blogue (BRAGA, 2008a). Por meio deste, são realizadas diversas ações que podem tornar tanto o(a) blogueiro(a) quanto seus blogs conhecidos.

No capítulo "Carlos Cardoso, seus Blogs e a Cultura Geek", justificamos as razões pelas quais consideramos Cardoso uma microcelebridade. A sua popularidade é determinada pelo conjunto de performances e interações realizadas pelo blogueiro, ao mesmo tempo em que estas são legitimadas pelas pessoas que acessam seus blogs. Os comentários deixados por indivíduos nesses espaços são analisados sob a perspectiva de que contribuem para a manutenção do status que Carlos Cardoso ocupa em seu circuito-blogue, assim como pela amplitude alcançadas por suas opiniões e publicações na blogosfera.

Para fins da presente análise, os comentários são informações publicadas em blogs por pessoas em seções específicas (seções de comentários), representando suas opiniões acerca dos assuntos abordados em um post ou em uma thread ${ }^{25}$ iniciada na própria seção de comentários. Os(as) comentaristas são aqueles(as) que expõem suas considerações e podem ser ou não visitantes habituais dos blogs. Os comentários surgem a partir de um post, embora, nem sempre, o assunto tratado pelo comentário aborde os temas existentes na publicação.

Em suma, a seção de comentários emerge como um espaço para que visitantes dos blogs de Cardoso possam realizar performances e interagir com os(as) demais e, ainda, para se inserir no circuito-Cardoso. Nesses ambientes, existe uma espécie de "etiqueta" a ser levada em consideração a cada participação, orientando performances, como participar da seção de comentários e, mesmo, como se inserir no debate. Nesse sentido, partimos do princípio de que, muitas vezes, o comentário gera múltiplas interpretações para os posts de Cardoso, colaborando para discussões entre comentaristas e o próprio blogueiro.

Sob a perspectiva da $\mathrm{AD}$, os comentários no Blog do Cardoso, no Contraditorium e no MeioBit refletem aspectos que norteiam e definem um grupo.

\footnotetext{
${ }^{25}$ Segundo Adriana Braga, thread é um "conjunto de comentários relativos a um mesmo tema dentro de uma lista de discussão ou Livro de Visitas (LV) de um blog, fenômeno interacional/verbal típico da interação social na Internet." (BRAGA, A., 2008a, p.281)
} 
São pessoas que acompanham as produções do blogueiro e, com certa frequência, expressam opiniões sobre o que encontram naqueles ambientes. Por outro lado, analisando tais publicações, percebemos que os(as) comentaristas acabam por reforçar características definidoras da persona digital de Cardoso, assim como contribuem para que o blogueiro permaneça com o seu papel de destaque e, consequentemente, aumente o valor simbólico de seu circuito-blogue. Nesse sentido, verificamos a existência de um lugar de "fala", assim como um público que dá sentido à posição assumida por Cardoso, até em momentos nos quais se expresse repúdio às performances on-line do blogueiro.

No sentido teórico, os comentários são as produções geradas a partir de um discurso que, por sua vez, não chegam a instituir uma "fala" completamente nova. Comentário, segundo Foucault (2010), é um discurso que, com base nas ideias contidas em outro, promove interpretações acerca do que foi escrito ou dito.

\footnotetext{
O comentário conjura o acaso do discurso fazendo-lhe sua parte: permite-lhe dizer algo além do texto mesmo, mas com a condição de que o texto mesmo seja dito e de certo modo realizado. A multiplicidade aberta, o acaso são transferidos, pelo princípio do comentário, daquilo que arriscaria de ser dito, para o número, a forma, a máscara, a circunstância da repetição. (FOUCAULT, 2010, pp. 25-26).
}

As ideias são organizadas, portanto, com base no discurso inicial, de forma que a construção do comentário referencie ideias expostas no princípio. O sentido de inicial, aqui apontado, sugere o discurso que suscitou a produção de comentários.

Em nosso caso, os comentários buscam expor opiniões, elogios, críticas, sugestões para Cardoso por meio da referência à publicação inicial, o post, que possibilitou essa interação denominada "comentário". O comentário pode acrescentar elementos que refutem ou confirmem as ideias presentes nas publicações de Cardoso. Além disso, o comentário legitima a imagem do blogueiro, como ele próprio se vê e como ele é visto tanto por seus(suas) seguidores(as) quanto por aqueles(as) que o criticam. Com base no sentido apontado por Foucault (2010), o comentário diz apenas o que pode ser interpretado a partir da ideia inicial, portanto não pode ser dissociado desse discurso.

Os comentários promovem o discurso e ampliam o seu alcance. Quando Foucault (2010, p.26) aponta que o "novo não está no que é dito, mas no 
acontecimento de sua volta [...]", percebemos que o discurso inicial se reflete por meio de outras vozes. Ou seja, o entendimento depende do contexto no qual o comentário surge e pode vir a revelar situações não previstas inicialmente. Essas situações, em nosso caso, são evidenciadas quando a discussão gerada pelos comentários promove novos pontos de vista com base no post publicado inicialmente por Cardoso. Embora tais ideias não estejam explicitamente contidas no post originador do comentários, existe uma ligação que, por isso, possibilitou outras interpretações. Portanto, ainda que os textos produzidos por Cardoso tenham um público-alvo - geeks brasileiros-, esses textos não ficam restritos a esse grupo.

As interpretações possíveis ao discurso se esgotam no momento em que este deixe de fazer sentido ao grupo ao qual esse discurso se destina. Tais interpretações buscam renovar a "fala" inicial permitindo que os(as) comentaristas se apropriem de questões pertinentes ao contexto no qual se encontram. Como por exemplo, a própria noção da cultura geek retratada por Cardoso que, por estar inserida da dinâmica interacional dos blogs, atrai um público diversificado com olhares diferentes acerca das referências elencadas pelo blogueiro em seus posts. Ainda que exista uma parcela da audiência que se sinta familiarizada com as ideias apresentadas por Cardoso, muitos(as) "paraquedistas" se acham ofendidos(as) com o estilo do blogueiro, bem como desconhecem as referências caras àqueles(as) que se autodenominam geeks.

Os dados foram analisados com base em uma dinâmica que se fundamenta nos seguintes pilares: a publicação de conteúdos na forma de posts de blog (alguns acompanhados de conteúdos audiovisuais e/ou sonoros) e a possibilidade de interação por meio do registro de comentários na seção de comentários. Sabemos que a simples publicação de um post não garante ao mesmo que o público participe por meio de comentários (BRAGA, A., 2008a). Nesse sentido, a análise realizada por meio dessa pesquisa não tem por interesse determinar o que leva uma pessoa a comentar em um post. Esse determinante é subjetivo e depende de uma série de variáveis as quais, por sua vez, não esgotam o ato de comentar. Em vez disso, prezamos pela observação dos comentários e no que eles geram em termos interpretativos e em termos interacionais, relacionados à legitimação da persona digital de Cardoso por meio de seus(as) comentaristas. 
O apontamento feito por Foucault (2010) reforça o lugar ocupado por um discurso para as pessoas que fizeram comentários a partir dele. Um discurso comentado merece atenção, tendo em vista que as inserções feitas não tentam esgotá-lo, mas abrem possibilidades interpretativas sobre a argumentação desse discurso. Por essa razão, achamos pertinente estudar os dados existentes nos comentários como resultados de diferentes visões sobre um mesmo assunto. Esses olhares podem traduzir elementos da cultura formada em torno de microcelebridades.

Nesse sentido, as referências mais importantes no momento do comentário dizem respeito apenas ao grupo do qual Cardoso diz fazer parte - o grupo de geeks. Ou seja, a cultura predominante, determinante da principal temática do circuito-Cardoso, contém elementos da cultura geek que, por sua vez, são também legitimados pelos comentários negativos. Nesse sentido, não trataremos de excluir a diversidade de referências dos(as) seguidores(as) das atividades on-line de Cardoso. Se na seção "Quem sou” Cardoso descreve-se como um geek da área de tecnologia, pensamos que ele deseja falar a esse grupo com o qual se identifica.

Nesse sentido, os(as) destinatários(as) das mensagens de Cardoso podem ser explicados por meio do conceito de face positiva:

\begin{abstract}
O simples fato de dirigir a palavra a alguém, de monopolizar sua atenção já é uma intrusão no seu espaço, um ato potencialmente agressivo. Esses fenômenos de polidez estão integrados na teoria denominada "das faces" [...]. Nesse modelo [teoria das faces], considera-se que todo indivíduo possui duas faces; o termo 'face' deve aqui ser tomado no sentido que este termo possui numa expressão como 'perder a face': - uma face negativa, que corresponde ao 'território' de cada um (seu corpo, sua intimidade, etc.); - uma face positiva, que corresponde à 'fachada' social, à nossa própria imagem valorizante que tentamos apresentar aos outros. (MAINGUENEAU, 2004, p. 38)
\end{abstract}

Por meio desse conceito, percebemos a construção daquilo que Cardoso pretende mostrar a um público em potencial, tomando por base aspectos considerados relevantes pelo blogueiro para essa apresentação pública em ambientes digitais. $\mathrm{O}$ seu enunciado é organizado com base no posicionamento tomado por sua persona e é reforçado pelas interações e performances exercidas nesses ambientes digitais nos quais atua. A "face positiva" de Cardoso pode ser explicada, também, por meio da representação de sua persona com base na relação entre plateia, fachada e bastidores proposta por Goffman (2002). Segundo Goffman (2002), estabelece-se uma expectativa por meio da escolha de palavras, de cenários e do cerimonial a ser apresentado. Essa expectativa não pode ser 
rompida, com o risco da "face positiva" (MAINGUENEAU, 2004) de Cardoso ser prejudicada.

Cardoso assume uma posição, por meio de sua persona digital, caracterizadora de sua performance em ambientes digitais. Ao desempenhar esse papel, o blogueiro gera expectativas em um público formado em torno de seu circuito-blogue. Ou seja, os seus posts promovem uma "encenação" na qual o blogueiro e os(as) demais participantes parecem ocupar papéis alinhados com aquele contexto em particular. Tais papéis revelam interpretações acerca da "fala" de Cardoso, ou seja, de seu enunciado.

O enunciado, segundo Maingueneau (1997), é o que é dito por uma pessoa como forma de demarcar a sua atuação em um dado contexto. Demarcar a sua atuação diz respeito às estratégias usadas por essa pessoa para determinar, de certa forma, que os(as) demais sejam impactados, tendo por base o discurso que é dito ou escrito, a escolha do espaço, as referências usadas com base naqueles(as) que ouvem ou leem a mensagem. O sentido de enunciado, nesse caso, cumpre as questões apontadas por Maingueneau (1997) quando se define o que falar, como falar, onde falar e a quem falar.

Portanto, o enunciado reflete os mecanismos e estratégias usados por Cardoso a fim de atrair visitantes e estimular seu público a comentar em seus posts. Podemos dizer que se trata de construir uma ideia que seja levada adiante e reflita a persona do blogueiro nos ambientes digitais em que atua. Em um sentido amplo, os comentários, enquanto referências de um discurso, são enunciados e, por essa razão, completam o conjunto de mecanismos e estratégias de manutenção de uma posição destacada no grupo.

O enunciado é construído por aquele(a) que conjuga os mecanismos e estratégias para legitimar posicionamentos ou ideias para indivíduos. O ponto de partida, para a análise realizada, surge da afirmação de Cardoso, na seção "Quem Sou Eu" do Blog do Cardoso de que o seu objetivo, na blogosfera, é se tornar um "blogueiro profissional". Essa declaração pode ser vista no relato a seguir:

Seção "Quem Sou Eu”, publicado no Blog do Cardoso

O objetivo era me tornar o primeiro blogueiro profissional do Brasil. Não desenvolvedorblogueiro, escritor-blogueiro, jornalista-blogueiro. Apenas blogueiro. Outras atividades que porventura apareçam complementarão os blogs, não o contrário. 
A noção de "blogueiro profissional" apresentada no trecho acima tem como pressuposto, além da obtenção de renda por meio da atividade, assumir uma postura especializada em gerenciar tanto blogs quanto as performances esperadas para esses espaços. Nesse sentido, poderíamos assumir que as performances de Cardoso são pensadas como parte de uma atividade profissional criada para esse fim exclusivo. Para tanto, ele precisa seguir algumas regras, conhecer a linguagem necessária para assumir esse papel, saber a quem falará para que essas pessoas legitimem essa posição e, ainda, onde e como fará essa abordagem. No trecho a seguir, podemos perceber a preocupação do blogueiro em sustentar esse papel e manter o nível profissional de sua atividade:

"A Blogosfera é Darwinista, não Marxista", publicado no Contraditorium em 23/07/2007

Qualquer um pode montar um blog e tirar um trocado. Se (grifo do blogueiro) não conseguir visitação por falta de divulgação, se (grifo do blogueiro) só ficar copiando posts dos outros, se (grifo do blogueiro) fizer mais um flogão de miguxa, a culpa não é do modelo. Como você quer viabilizar um blog com 10, 20 visitas/dia? Em verdade nesse modelo a blogosfera já é quase marxista, nossa remuneração é diretamente proporcional ao nosso trabalho. O Edney só começou a ganhar dinheiro mesmo quando dedicou $100 \%$ de seu tempo ao blog. Alguém que só escreve no final de semana, copia um post do MeioBit e diz que tem blog vai concordar contigo que o modelo não funciona. Claro que não funciona. É um dos preceitos básicos da economia, você não pode ganhar mais do que você produz. Não é culpa do Google. Nenhum dos modelos que você apresentou foge disso. Uma empresa $\mathrm{NÃO}$ vai aceitar patrocinar um blog sem audiência. $\mathrm{O}$ blogueiro cuidar ele mesmo do agenciamento de publicidade é algo muito, muito complicado. Acima de um certo grau de profissionalização exige envio de nota fiscal ou RPA, contabilidade, contato com anunciantes, negociação, assinatura de contratos... se para um problogger isso já é quase inviável, dado o tempo consumido, imagine para um blogueiro eventual?

A criação de uma empresa/grupo para cuidar disso seria reinventar a roda. Já há várias empresas oferecendo esses serviços, inclusive uma tal de Google. Eu entendo a comissão do Google como um preço a pagar para justamente não ter que lidar com toda a parte burocrática da publicidade.

Nesse trecho, Cardoso parece conhecer os mecanismos necessários para se tornar um "blogueiro profissional" e, por conhecê-los, compartilha com seu público como forma de justificar sua performance. Por conseguinte, assume uma posição de alguém com informações privilegiadas e, por isso, possui um papel de destaque.

Portanto, o enunciador é aquele que constrói o enunciado e de onde parte a ideia a ser exposta por meio dos conteúdos (MAINGUENEAU, 1997; 2004). Em nosso caso, Cardoso pode ser considerado um enunciador, tendo em vista que suas 
ideias refletem seu posicionamento dentro do universo do "blogueiro profissional" e da cultura geek. O enunciador possui o controle para organizar ideias e direcionar como um grupo deveria se posicionar diante de um fato ou situação (MAINGUENEAU, 2004).

A posição do enunciador é única, pois ele conhece os conteúdos que produz. Embora o enunciado produzido por ele venha a ser interpretado pelos comentários, por exemplo, tais interpretações podem não coincidir com a ideia do enunciador (MAINGUENEAU, 2004). O enunciador sempre se dirige a algo ou a alguém, aos quais toma como referência para a construção das ideias embutidas em seus conteúdos.

[...] Toda enunciação, mesmo produzida sem a presença de um destinatário, é [...] marcada por uma interatividade constitutiva (fala-se também de dialogismo), é uma troca, explicíta ou implícita, com outros enunciadores, virtuais ou reais, e supõe sempre a presença de uma ou de outra instância de enunciação à qual se dirige o enunciador e com relação à qual se constrói seu próprio discurso. (MAINGUENEAU, 2004, p. 54)

Nesse sentido, o enunciador organiza as ideias propostas de uma forma que chamem a atenção daqueles(as) aos quais se dirige, revelando qual a posição em que se encontra nesse contexto. No trecho abaixo, percebemos a forma pela qual Cardoso conduz suas ideias, de modo a induzir uma determinada interpretação sobre o post publicado:

Atleta sem duas pernas não se classifica para as Olimpíadas. É um inválido mesmo, publicado no Blog do Cardoso em 21/07/2008 - 99 comentários

Tem aleijado que não se enxerga. Esse tal de Oscar Pistorius, ao invés de ficar sentado o dia inteiro em uma cadeira de rodas com um cobertor tampando as pernas (ou o que sobrou delas) resolveu virar... atleta.[...]

Ele não pode ter a pretensão de conseguir superar pessoas normais. Vejam vocês, competindo com atletas de verdade o Pistorius se arrastou, praticamente de muletas, correndo 400 metros em INTERMINÁVEIS 46,25 segundos. Muito distante do índice MÍNIMO para Olimpíada, de 45,55 segundos.

E seria até injusto comparar o pobre aleijado com o recorde MUNDIAL de 400m rasos, nos pés de Michael Johnson, com 43,18 segundos.

Entendeu, aleijadinho? Você e suas perninhas de brinquedo não tem como competir com um atleta de verdade, você é MAIS DE TRÊS SEGUNDOS MAIS LENTO do que o campeão mundial na categoria. Se enxerga.

PS: Favor desconsiderar em quantos minutos (ou horas, no meu caso) $99,99 \%$ da população mundial levam para correr 400m, senão o texto acima perde todo o sentido.

Fonte: New Scientist

No trecho acima, Cardoso parece forçar uma leitura preconceituosa sobre a matéria do post. Por outro lado, o blogueiro se dirige a seus(suas) leitores(as), conhecedores de suas táticas e apelos a sarcasmos e ironias como uma forma de 
expressar sua opinião sobre determinado assunto. A partir dessa abordagem, de induzir interpretações conflitantes, Cardoso pretende estimular debates e considerações de visitantes nas seções de comentários de seus blogs.

O diálogo existente nos processos enunciativos revela, portanto, a participação de outros atores na interpretação e, posteriormente, no comentário ao discurso do enunciador. Os(as) demais participantes atuam de forma a interpretar esse discurso com suas próprias referências, buscando sempre pelo que está contido na "enunciação". Esses indivíduos, portanto, são "co-enunciadores" (MAINGUENEAU, 2004) de um enunciado do qual participam e com o qual dialogam.

O papel de co-enunciador (MAINGUENEAU, 2004) cabe àquele(a) que, por meio de interpretações, produz novos conteúdos a partir de um discurso que chame a sua atenção. Esse conteúdo produzido é, no caso dessa pesquisa, o comentário (FOUCAULT, 2010). As interpretações feitas ao discurso a que se referencia se fundamentam em saberes e conhecimentos prévios à enunciação. Além disso, cronologicamente, tais interpretações adquirem novas perspectivas com base no "contexto" (MAINGUENEAU, 2004) em que o "co-enunciador" se encontra. Cardoso, no contexto dos ambientes digitais, precisa de co-enunciadores para seu discurso. Essa dependência da audiência é realçada pelos coenunciadores (MAINGUENEAU, 2004, pp. 44-45).

[...] não é um enunciado que faz referência: é o enunciador que, por meio de seu enunciado, deverá passar ao co-enunciador as instruções necessárias para identificar os referentes por ele visados em um determinado contexto. A referência é, portanto, uma atividade que implica a coordenação dos co-enunciadores e poderá malograr, caso o co-enunciador, por exemplo, se engane de referente. (MAINGUENEAU, 2004, pp. 179-180)

A referência, no caso de Cardoso, fica evidenciada na categorização de comentaristas, com base na interpretação que esses teriam das opiniões do blogueiro. Uma vez que alguém mencione algo fora de contexto ou se engane com relação às ideias contidas nos posts, este(a) comentarista será segregado(a) e será alvo de piadas por parte do grupo que se encontra alinhado aos posicionamentos de Cardoso. No exemplo abaixo, notamos como o enunciador, Cardoso, organiza as ideias de modo a conquistar o seu público, mesmo que tenha atraído pessoas com gostos e referências diferentes dos seus: 
"Ex-Gay, Ex-Aidético, Ex-Canceroso e Escroto por Mentir Descaradamente", publicado no Blog do Cardoso em 24/01/2008

Alan Fleischman. 260 weeks ago

Pessoal, não tenho nada haver com o vídeo, mas sou evangélico. Entre todos os lugares existem pessoas boas e pessoas más e, se a pessoa que está falando no vídeo está mentindo ou falando a verdade realmente não sei e não me interessa, mas o que sei é que, para falar mau, seja de qual assunto for, todos querem, todos falam. Charlatanismo ainda é crime em nosso país e, se alguém realmente tem certeza (assim como todos dizem), identifiquem o cidadão e entre com um processo contra ele. [...] Se quer entender o que falo, imagine a seguinte situação:

"Você está em um vôo internacional, em cruzeiro e, de repente, o avião começa a cair e o piloto diz que, em torno de 5 minutos o avião irá tocar ao solo e não há nenhuma chance de reverter o pane". Duvido se você iria zombar de Jesus, de Deus".

Pense bem antes de escrever alguma coisa, reflita e tente entender, nem que seja para falar mal tendo a consciência e a devida explicação.

Thiago 260 weeks ago

[...]Estaria muito ocupado entrando em pânico e/ou procurando o pára-quedas ou equivalente.[...]

Cardoso. 260 weeks ago

Alan, se eu for um muçulmano devoto, irei pedir por Alah, se eu for Hindu irei rezar por Shiva, Ganesha ou outro qualquer, e se eu fosse um grego antigo religioso com certeza estaria rezando por uma intervenção de Apolo. No momento em que você diz que não quer afirmar se o cara está certo ou errado, você já demonstrou sua posição. E não é questão de generalizar, $90 \%$ das seitas protestantes são puro charlatanisto e fanatismo. Isso é um fato

Allan. 260 weeks ago

"90\% das "seitas" evangélicas são puro charlatanismo e fanatismo. Isso é um fato."

Até concordo ! Ainda bem q tem os $10 \%$ restantes...

Salsinha de Cristo, mesmo..

É duro viver enganado !!!

No exemplo acima, notamos como Cardoso se posiciona dentro do grupo ao assumir o papel de enunciador. Ao expor sua opinião sobre a religião em comento, o blogueiro reforça que o seu discurso é um fato incontestável para o contexto do circuito-Cardoso. Por sua vez, em complemento à ideia de Cardoso, o comentarista favorável ao blogueiro "enquadra" aquele que contrariou as ideias predominantes nesse circuito-blogue, usando um apelido. Nesse caso, a referência é reforçada tanto por Cardoso quanto pelo membro de sua corte de seguidores(as).

Os co-enunciadores usam os comentários para expor suas opiniões sobre o que foi publicado. Interpretam a mensagem, tendo como referência seu conhecimento linguístico, semântico e cultural, e participam do post. Essa participação merece atenção, tendo em vista que depende de uma performance cara ao circuito-blogue. A apresentação de si e a abordagem feita nesses ambientes precisa ser acompanhada, enquanto parte do contexto interacional e performático, da publicação de um comentário.

Ao longo do texto, mencionamos algumas vezes a palavra "contexto" para falar a respeito das circunstâncias que organizam as interpretações do enunciado 
de Cardoso. A fim de evitar entendimentos distantes de nossa proposta, cabe definir como trataremos a questão do contexto em nossa pesquisa.

Podemos dizer que o contexto apontado na forma do circuito-blogue seja composto de três elementos, segundo a definição proposta por Maingueneau (2004). Para o autor, "o contexto não é necessariamente o ambiente físico, o momento e o lugar da enunciação." (MAINGUENEAU, 2004, p. 26). Por essa razão, o contexto é: o contexto situacional, o cotexto e os saberes anteriores à enunciação. Para Maingueneau,

\begin{abstract}
[os cotextos] são as sequências verbais encontradas antes ou depois da unidade a interpretar. [...] os enunciados geralmente são fragmentos de uma totalidade mais ampla: um romance, uma conversa, um artigo de jornal etc. [...] O recurso ao cotexto mobiliza a memória do intérprete, que vai colocar uma dada unidade em relação a uma outra do mesmo texto. (MAINGUENEAU, 2004, p. 27)
\end{abstract}

A noção de contexto abordada pela presente pesquisa compreende a análise dos pontos de vista e das interpretações, a partir do enunciador e dos coenunciadores, para a legitimidade do discurso de Cardoso em seu circuito-blogue. Portanto, as referências usadas pelo blogueiro e por seus(suas) comentaristas determinam de onde eles(as) falam, o que eles(as) pensam e como eles(as) enxergam os(as) demais participantes do circuito-Cardoso.

Os dados analisados compreendem o conjunto de ideias expostas por uma microcelebridade que fala a um público considerável. Considerável no sentido numérico, compreendendo uma média de visitação diária de 20 mil pessoas para cada blog ${ }^{26}$. A partir do momento que Cardoso publica seus conteúdos, suas publicações revelam ideias tomadas com base em seu posicionamento para os ambientes digitais. Imediatamente, reconhecemos duas posições, uma ampla e outra específica: Cardoso considera-se um geek e pretende ser um "blogueiro profissional". A persona geek do blogueiro, como sabemos, existe antes mesmo da Internet e se estende por referências reproduzidas pela TV, pelo cinema, pela imprensa e pela publicidade, por exemplo. Já o "blogueiro profissional" parte do ambiente digital de um blog e das interações e performances realizadas neste ambiente.

Considerando o grupo de visitantes e de comentaristas nos blogs em análise e, especialmente, as manifestações em forma de comentário, Cardoso tem

\footnotetext{
${ }^{26}$ Valor referente ao ano de 2006. In: "Quem sou eu", publicado no Blog do Cardoso.
} 
construído um discurso alinhado ao seu papel de microcelebridade. À medida que o seu discurso demarca posicionamentos e traduz opiniões, culminando com a existência de seguidores(as), podemos falar em enunciado, enunciador e coenunciadores. Precisamos ressaltar, ainda, as articulações de sentido, mediadas tanto por Carlos Cardoso quanto por seus (suas) comentaristas.

\subsection{Natureza dos Dados}

Os dados analisados são originários de três blogs em que Cardoso possui publicações de sua autoria: Blog do Cardoso, Contraditorium e MeioBit. Os dois primeiros foram criados pelo blogueiro e no último Cardoso assume as posições de editor-chefe e de colunista fixo. O critério de escolha dos posts e, por conseguinte, dos comentários, fundamentou-se na maior relação entre comentários/post compreendida entre os anos de 2005 e 2011 para cada um dos blogs selecionados. Ou seja, para cada ano foi escolhido um mês no qual a proporção comentários/post obteve um quociente maior. A seguir, a fim de ilustrar o recorte realizado, os gráficos com os dados dos três blogs:

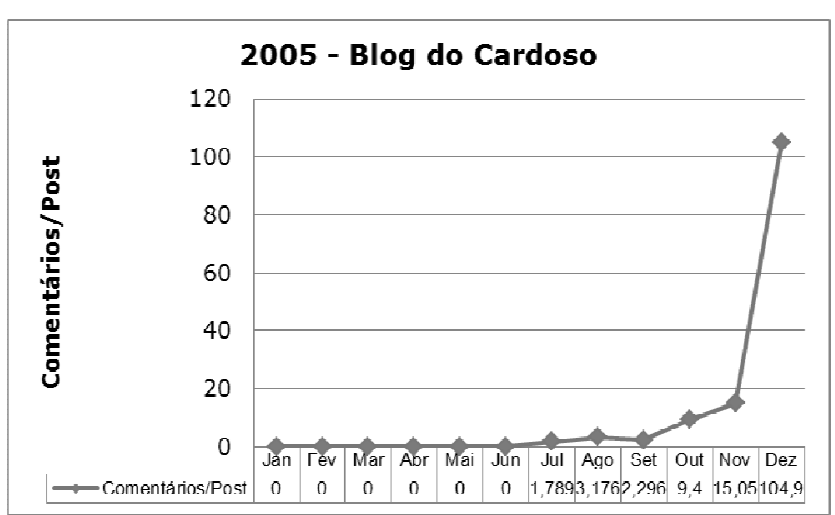

Figura 1: Comentários/Post em 2005 - Blog do Cardoso

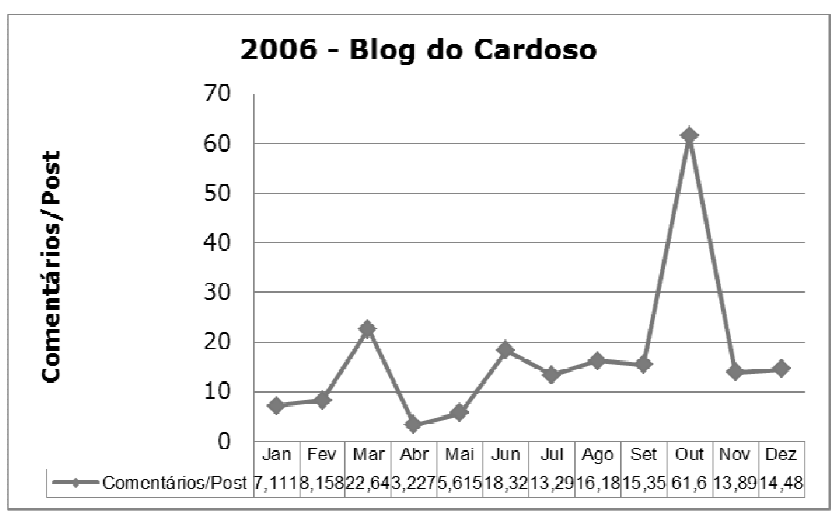

Figura 2: Comentários/Post em 2006 - Blog do Cardoso 


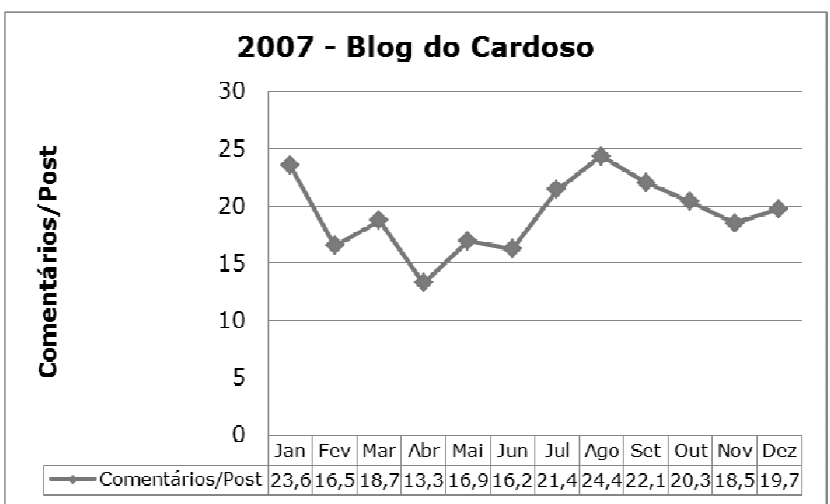

Figura 3: Comentários/Post em 2007 - Blog do Cardoso

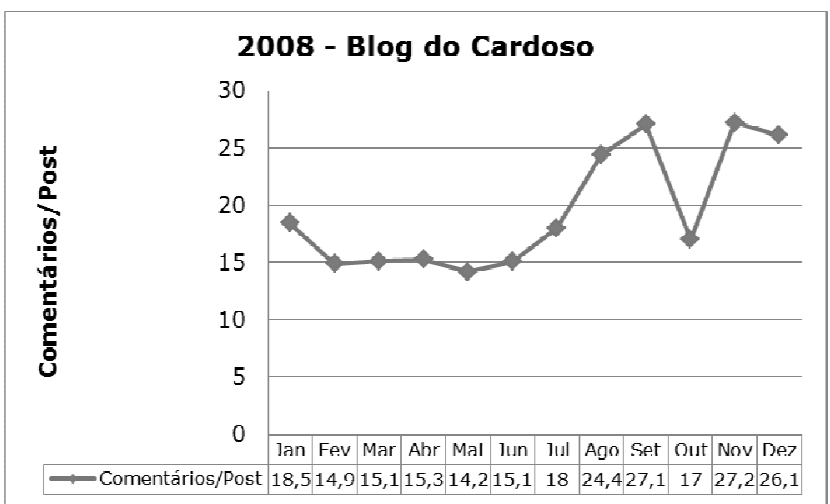

Figura 4: Comentários/Post em 2008 - Blog do Cardoso

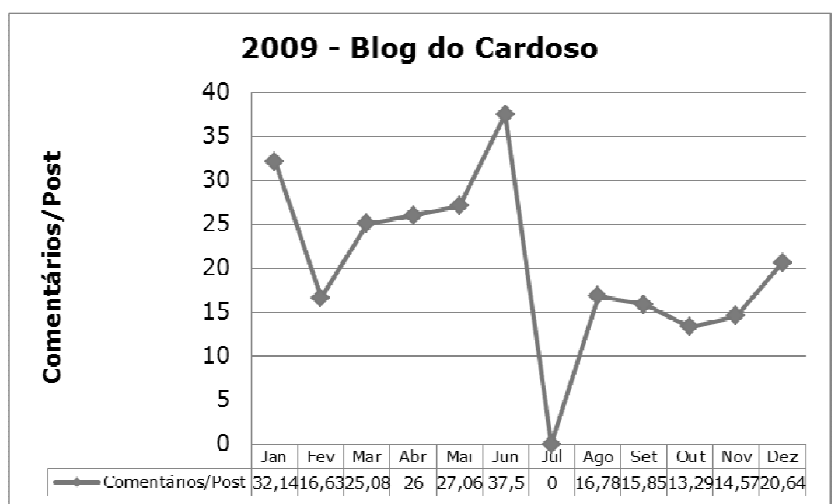

Figura 5: Comentários/Post em 2009 - Blog do Cardoso 


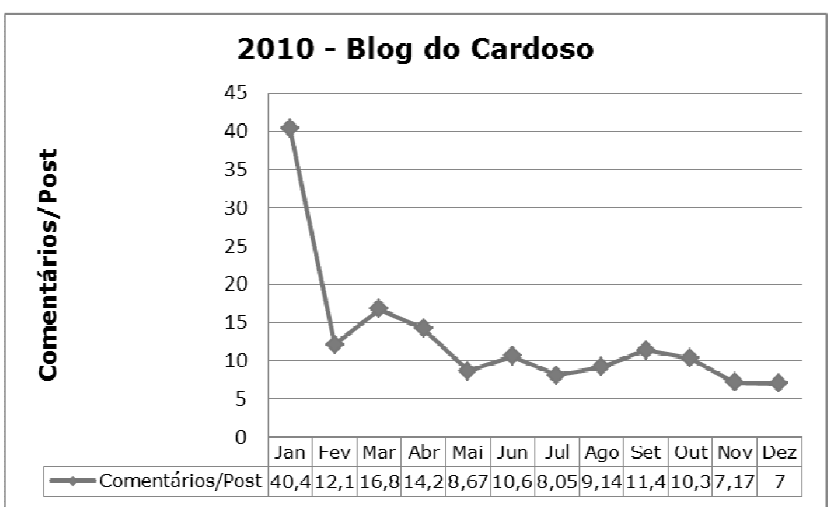

Figura 6: Comentários/Post em 2010 - Blog do Cardoso

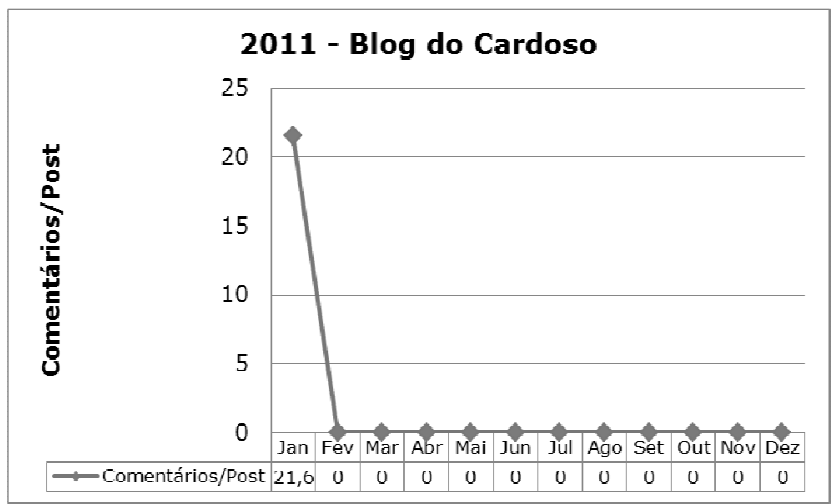

Figura 7: Comentários/Post em 2011 - Blog do Cardoso

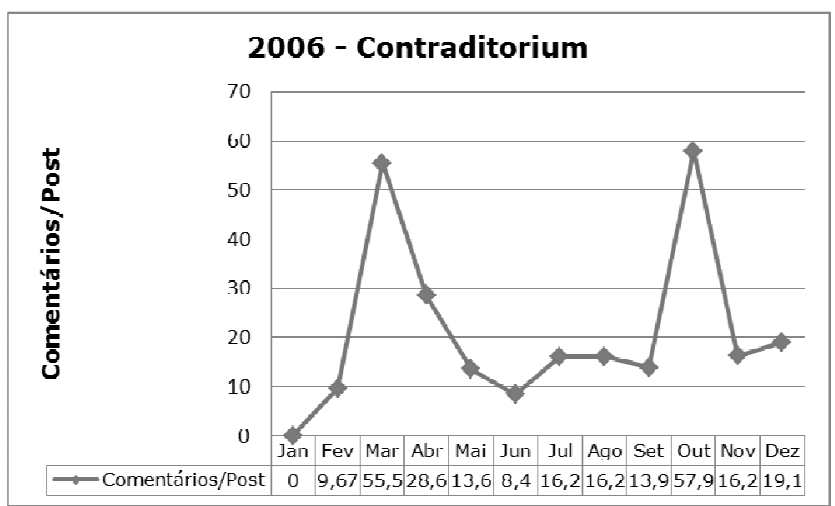

Figura 8: Comentários/Post em 2006 - Contraditorium 


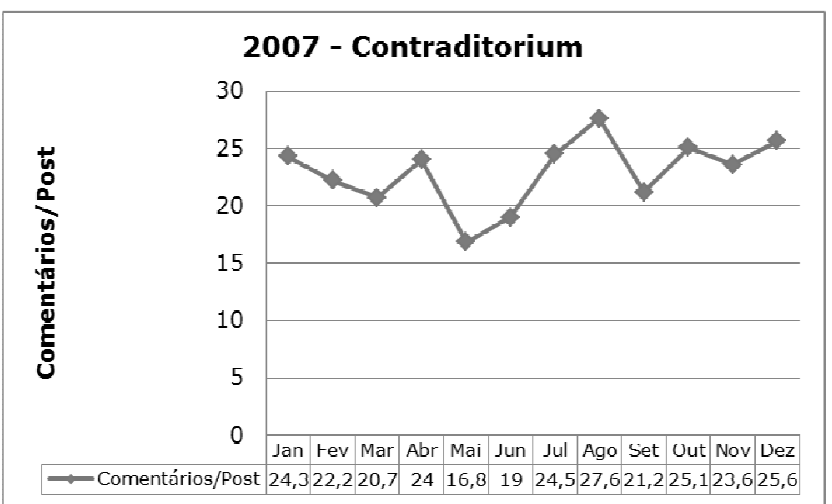

Figura 9: Comentários/Post em 2007 - Contraditorium

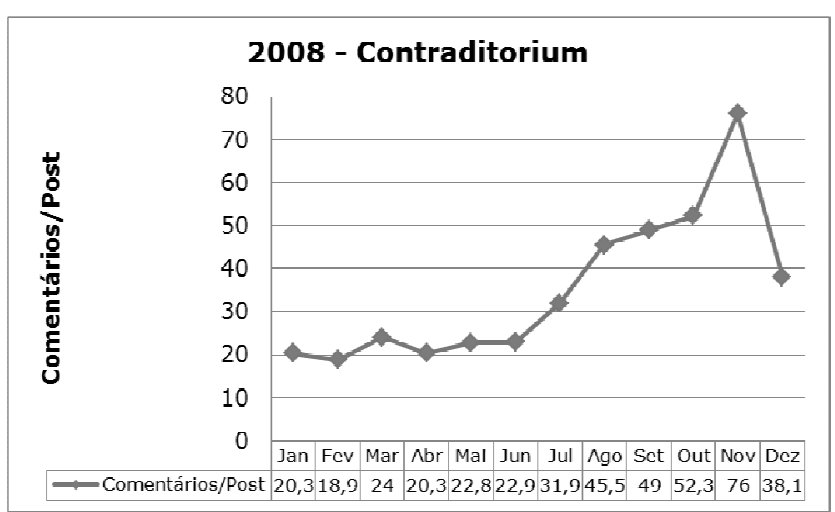

Figura 10: Comentários/Post em 2008 - Contraditorium

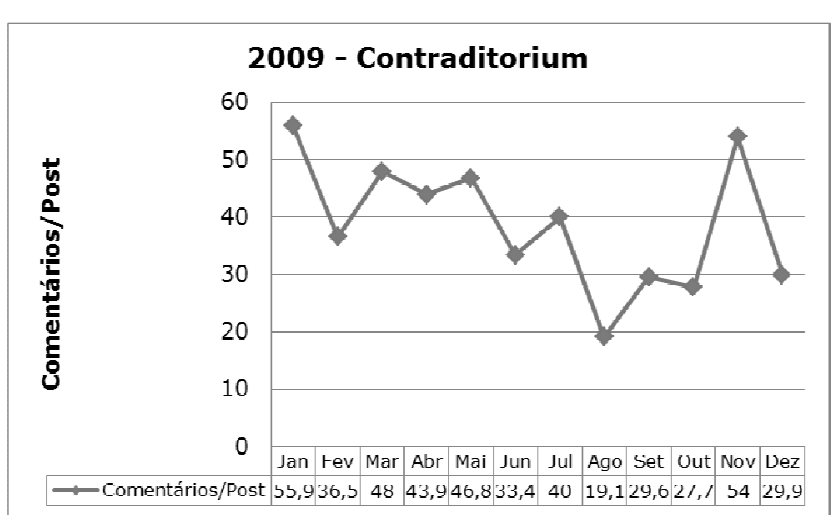

Figura 11: Comentários/Post em 2009 - Contraditorium 


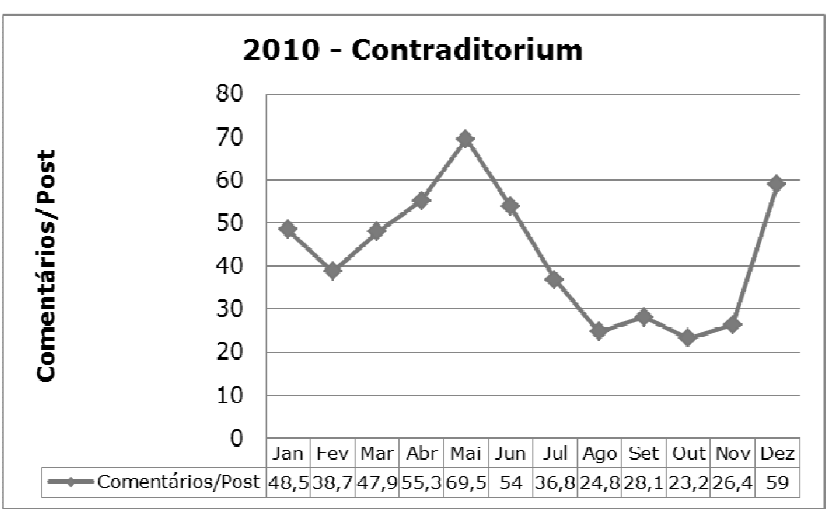

Figura 12: Comentários/Post em 2010 - Contraditorium

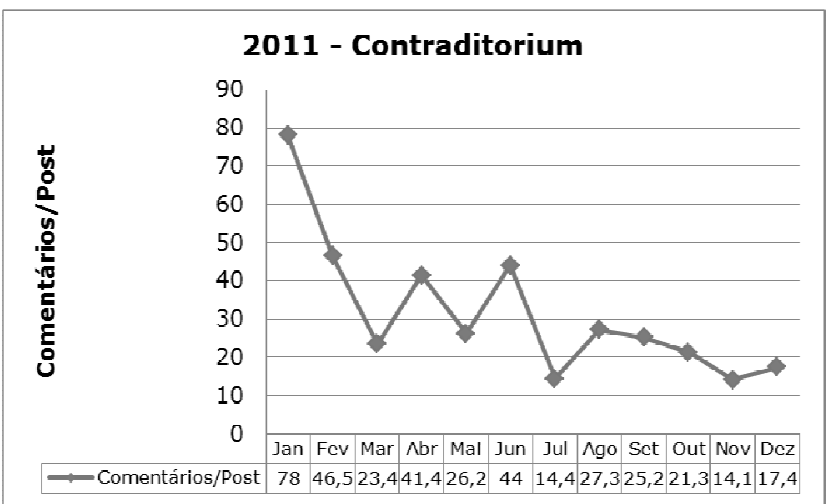

Figura 13: Comentários/Post em 2011 - Contraditorium

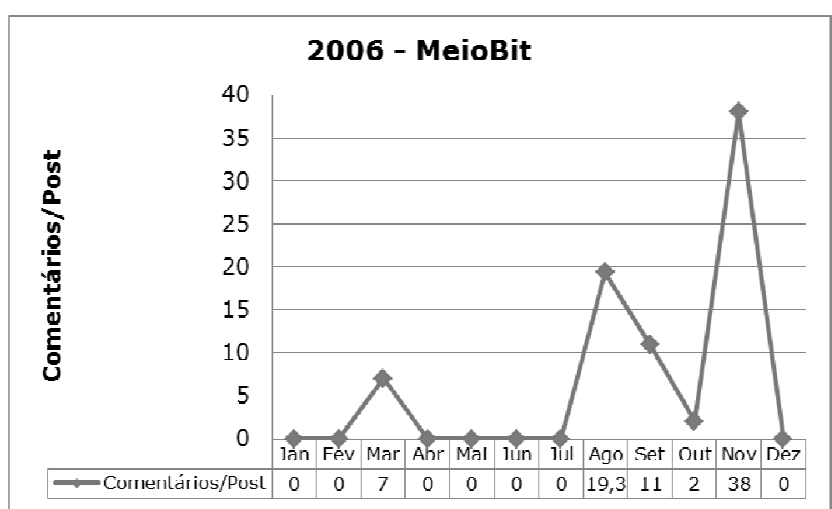

Figura 14: Comentários/Post em 2006 - MeioBit 


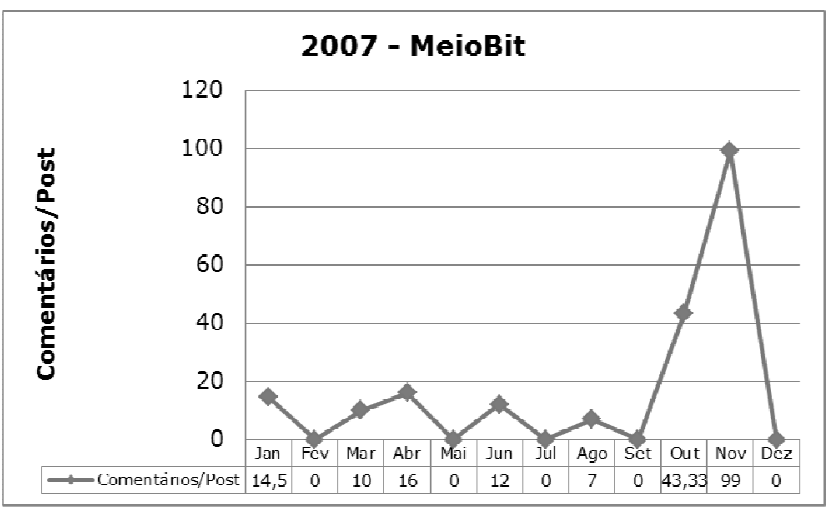

Figura 15: Comentários/Post em 2007 - MeioBit

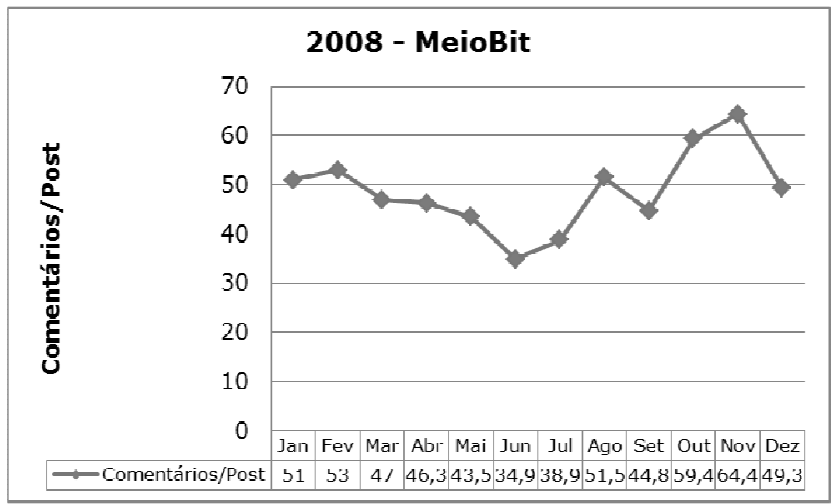

Figura 16: Comentários/Post em 2008 - MeioBit

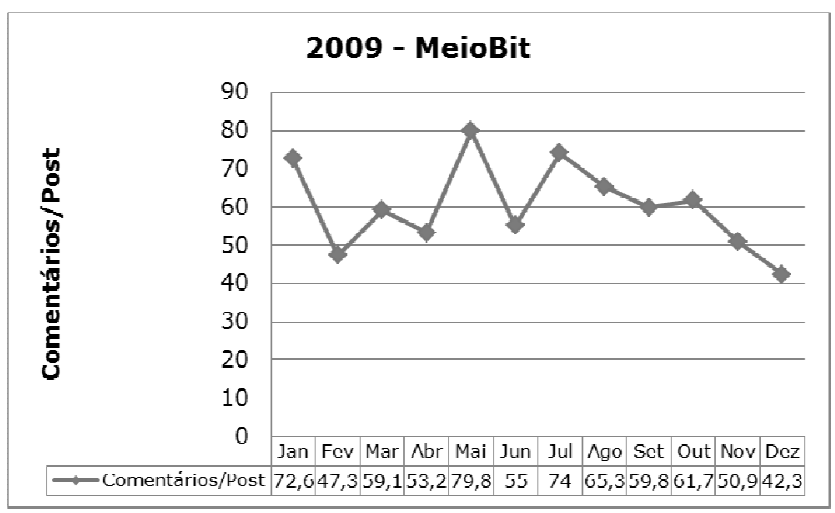

Figura 17: Comentários/Post - MeioBit 


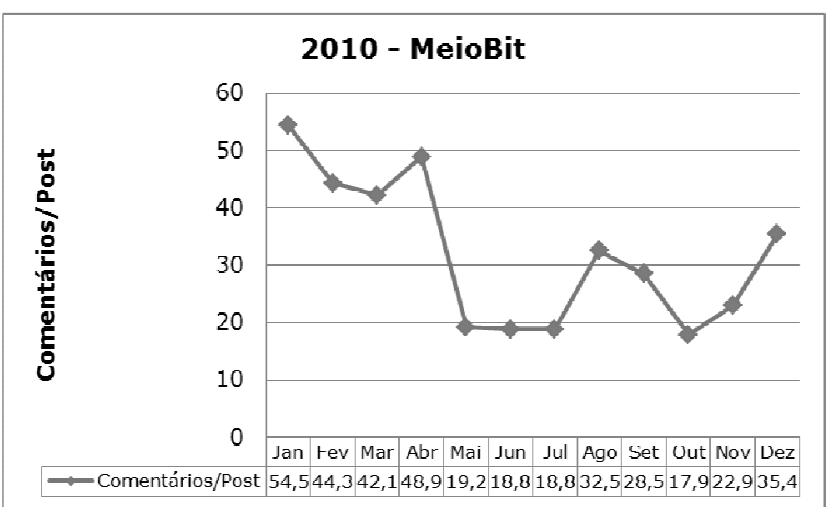

Figura 18: Comentários/Post em 2010 - MeioBit

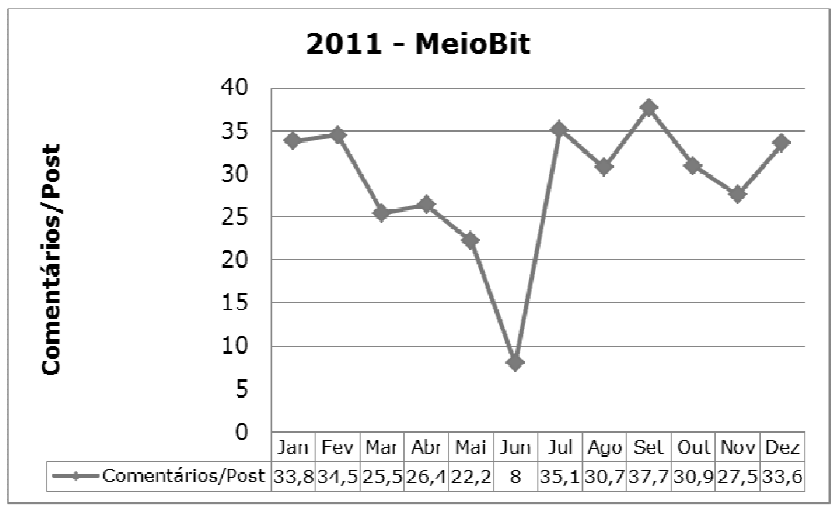

Figura 19: Comentários/Post em 2011 - MeioBit

A análise empreendida pela presente pesquisa compreende uma série de comentários feitas aos posts publicados no Blog do Cardoso, no Contraditorium e no MeioBit. No total foram analisados 20 posts. São eles:

Blog do Cardoso

Ou dá ou desce, Bispo Macedo, publicado em 01/12/2005 - 1.181 comentários

Exclusivo: Fotos do Acidente do Vôo 1907 da Gol de dentro do Avião, publicado em 26/10/2006 - 1.106 comentários

Aviso aos Crentes Idiotas: Vocês serão banidos daqui, publicado em 21/08/2007 - 88 comentários

Responda rápido: Isso aconteceria na Suécia?, publicado em 27/11/2008 - 99 comentários

O que é pior matar 20 milhões ou sacanear um pedaço de pão?, publicado em 15/01/2009 58 comentários

Imagens Exclusivas: Terremoto no Haiti, publicado em 12/01/2010 - 215 comentários

Impressionante a Xuxa russa, publicado em 03/01/2011- 34 comentários

Contraditorium

Quem quer ver as fotos dos corpos do acidente da Gol, publicado em 06/10/2006 - 824 comentários

Perdendo a fé na humanidade, publicado em 07/08/2007 - 67 comentários

Eu não quero brincar, então estou saindo do play, publicado em 25/11/2008 - 242 comentários

Controle de Zoonoses não protege seu animalzinho e eu adorei, publicado em 13/01/2009 160 comentários 
Senhor Jesus: Mande outro meteoro. Assim como os dinos, nós não demos certo, publicado em 17/12/2010 - 137 comentários

Por favor, não matem meus heróis, publicado em 25/01/2011 - 104 comentários

MeioBit

Playstation no Brasil - precinho camarada: R\$ 7980,00, publicado em 30/11/2006 - 38 comentários

Stallman está certo: Programa tem que rodar na máquina, publicado em 23/11/2007 - 99 comentários

Brasil e Moçambique vão cooperar no desenvolvimento cientifíco nas telecomunicações, publicado em 25/11/2008 - 396 comentários

Linux atinge marca histórica de $1 \%$ do mercado, publicado em 02/05/2009 - 365 comentários

Algo misterioso vai acontecer, publicado em 28/04/2010 - 121 comentários

Agora a Microsoft Reinventa o Messenger, publicado em 28/10/2010 - 121 comentários

GVT anuncia GVTTV e miraculosamente foge do mais do mesmo, publicado em 16/09/2011 - 256 comentários

Além desses posts, selecionamos outros que exemplificassem dinâmicas e práticas sociais interessantes para as categorias de análise identificadas no circuito-Cardoso. Dentre estes, selecionamos:

Blog do Cardoso

Mini-Meme: 5 besteiras que me irritam, publicado em 01/04/2007 - 99 comentários

O Acidente da Tam e o Marketing de Avestruz, publicado em 17/07/2007 - 92 comentários Apagão da Internet: Orkut vai sair do ar!, publicado em 02/08/2007

Aviso aos crentes idiotas: Vocês serão banidos daqui, publicado em 21/08/2007

Estupraram a Mônica!, publicado em 15/08/2008 - 112 comentários

Vegetarianos, vejam o que lhes espera, publicado em 16/12/2009

Contraditorium

Atendendo a pedidos - mais ou menos, publicado no Contraditorium em 03/12/2008

Deixem o Arcebispo de Recife em paz!, publicado no Contraditorium em 2009 - 230 comentários

O Grande Post das Salsas Aéreas, publicado no Contraditorium em 04/06/2009 - 148 comentários

Um guri de sorte com 13 anos e câncer no fígado, publicado no Contraditorium em 03/05/2010 - 145 comentários

Ao contrário de Ayrton Senna a F1 está morta e enterrada, publicado no Contraditorium em 2010 - 69 comentários

\section{MeioBit}

Blue me punto para Microsoft, publicado no MeioBit em 05/10/2007

Asus vai incorporar Splashtop Linux em todas as suas placas, publicado no MeioBit em 15/05/2008 - 190 comentários

TechEd 2008 - Linux Marcando Presença, publicado no MeioBit em 15/10/2008 - 467 comentários

10 hábitos que nenhum micreiro se lembra mais, publicado no MeioBit em 03/12/2008 263 comentários

Engadget declara guerra aos trolls, publicado no MeioBit em 02/02/2010 - 303 comentários Para Carl, publicado no MeioBit em 09/11/2010 - 143 comentários

DMR - Eulogia a um Gigante, publicado no MeioBit em 14/11/2011 - 141 comentários

Portanto, o desenvolvimento da presente pesquisa compreendeu a análise de 38 posts provenientes do Blog do Cardoso, do Contraditorium e do MeioBit. 
Os(as) visitantes dos blogs de Cardoso podem participar, se envolverem em discussões e outras formas de interações com os(as) demais ao publicarem comentários contendo considerações sobre o blogueiro e sobre seus posts. A dinâmica desses espaços foi observada levando-se em conta como o status e as performances de Cardoso são legitimadas a partir da perspectiva de comentaristas. Dentro do grupo, percebemos posicionamentos opostos cujas opiniões favorecem ou criticam a "fala" de Cardoso. Por sua vez, ao defenderem suas visões de mundo, esses(as) comentaristas complementam os posts - logo, o discurso de Cardoso - e renovam as diversas interpretações geradas a partir dessas performances. Por se tratar de uma participação de audiências, os comentários dão legitimidade, assim como o reconhecimento dos pares à atuação da microcelebridade.

\begin{abstract}
Nesse sentido, podem ser destacados dois grandes modos de obtenção de credibilidade, prestígio ou respeito na publicação de conteúdos no espaço digital. Alguns indicadores utilizados para esse fim parecem ser os números de circulação de visitantes e comentários registrados (índice verificável em um contador) e a incidência de citação em blogs já estabelecidos e respeitados (verificável através de listagem de preferências que cada blog disponibiliza ou por hiperlinks do corpo do texto dos posts). (BRAGA, A.,2009, p. 156)
\end{abstract}

O número de comentários recebidos por cada post funciona como um determinante da popularidade de uma microcelebridade como Cardoso, visível para todos(as) visitantes desses blogs. Por esse motivo, percebemos, na análise dos comentários para essa pesquisa, o interesse do blogueiro em aumentar não só o volume de visitantes, mas de criar estratégias que estimulem a participação por meio de comentários. Isso seria uma forma, ainda, de gerar renda para o blogueiro, como podemos perceber no exemplo a seguir:

Querido Leitor: Sua fidelidade não paga meu aluguel, publicado no Contraditorium em 08/01/2007

Segundo o Rafael uma pesquisa do Google apontou que o visitante paraquedista tem 14 vezes mais chance de clicar em um banner do que um visitante eventual. Um leitor que utilize RSS tem 0\%. Mesmo assim ter um conteúdo de qualidade e uma base de leitores consistente é essencial (grifo do blogueiro), mesmo que não te dêem um centavo diretamente.[...]

TODOS os seus leitores são fonte de renda, mas os que clicam nos banners são os menos significativos. Esses vão te dar dinheiro mas não vão te dar status.

[...] Falo deposição no Google (grifo do blogueiro). Um site com muitos links de sites e blogs respeitáveis tem muito mais chances de emplacar um primeiro lugar do que um blog sem NENHUM conteúdo, sem referências externas e que acabou de ser criado.[...]

Assim, para viver um grande amor, digo, para se dar bem na blogosfera, você tem que dosar. Não adianta. Se você escrever somente (grifo do blogueiro) para um grupo de leitores, está fadado ao fracasso. Se torna ou blog com relativamente pouquíssimos 
acessos, por só falar de assuntos desinteressantes para a maioria, ou assume uma postura popular e se torna um kibe, o que em minha opinião é um tipo de fracasso bem pior.

Falar, profissionalmente para um único grupo, na blogosfera brasileira é economicamente inviável. [...]

O cara que te xinga não é o seu público. Ele é o paraquedista que caiu no lugar errado. Você não pode considerar o cara que sai atrás de fotos de cadáveres e musa-do-big-brotherpelada como público perdido. Esse nunca (grifo do blogueiro) vai ler o que você escreve. A parte ruim é que são maioria absoluta. Então, como fazer para sobreviver? Simples, escreva para os dois. Dose seus textos para que o paraquedista caia no meio de uma reunião de seus leitores fiéis. Sabe aquele chato que chega tarde, fica pouco, fala demais mas deixa $\mathrm{R} \$ 50,00$ na mesa pra ajudar na conta do bar? Esse (grifo do blogueiro) é o visitante via Google.

Escreva os melhores textos que puder, para garantir um contingente de LEITORES (grifo do blogueiro), e escreva também sobre temas caros à plebe, pois o pessoal que iscrevi axim, minha miguuuxita (grifo do blogueiro), é que vai pagar o leitinho das crianças. Se você for boa mesmo, seus textos "populares" ficarão interessantes para seus leitores habituais, e convenhamos, os paraquedistas não vão ler mesmo, pra quê baixar a qualidade ao nível que eles entendem?

Cardoso adota uma postura de quem possui uma ampla experiência na área de blogs, assim como no trato de visitantes desses espaços. Por reunir esse nível de conhecimento, o blogueiro fala como um expert e que, por isso, conquistou uma posição de destaque e um circuito-blogue com visibilidade. Percebemos aí como o conhecimento sobre o funcionamento de blogs, performances e interações se torna importante, especialmente se puder ser demonstrado e comprovado como aparece no trecho acima. A demonstração da qual falamos é um passo que legitima o lugar privilegiado ocupado por Cardoso, assim como é um parâmetro para a obtenção de credibilidade e respeito na blogosfera.

Com oito anos de blogosfera, Cardoso já foi considerado um dos blogueiros mais populares do Brasil pela revista $I D G$ Now em $2007^{27}$ e recebeu o prêmio de melhor blog individual pelo Best Blogs Brazill ${ }^{28}$. Consequentemente, o reconhecimento, na forma de premiações, tende a aumentar o volume de visitantes, além de elevar o valor simbólico do circuito-blogue de Cardoso.

O Blog do Cardoso foi o primeiro blog criado por Cardoso. Segundo o registro na seção "Arquivos" do blog, o primeiro post data de 21/05/2005 intitulado "Antipost", como podemos ver a seguir:

Antipost, publicado no Blog do Cardoso em 21/05/2005

${ }^{27}$ FELITTI, Guilherme. Os 10 Blogs mais Populares da Internet em 2007. In: IDG NOW, São Paulo, 21/12/2007. Disponível em: <http://idgnow.uol.com.br/internet/2007/12/21/idgnoticia.2007-1221.8509435884/>. Acesso em 20/12/2012.

${ }^{28}$ PEIXOTO, Cynara. Resultado da 1 ${ }^{\text {a }}$. Edição do BBB - Best Blogs Brazil. In: MundoTecno, São Paulo, 13/12/2007. Disponível em: <http://www.mundotecno.info/blogs/resultado-final-do-bbbbest-blogs-brazil>. Acesso em 20/12/2012. 
Onde nosso herói revê seus conceitos, adere aos blogs, muda de vida, começa a fazer teatro infantil...

OK, talvez não chegue a tanto. Nem irei postar poesias de minha lavra. Até pq elas não existem. MAS irei postar o que bem entender, duela a quiem duela. Me reservo esse direito.

Quem não concordar, bem... ALT+F4 serve pra isso.

Nesse post, notamos características que norteiam o comportamento do blogueiro até os dias atuais, como, por exemplo, sarcasmos, referências a cultura geek e o modo autoritário de Cardoso administrar seus blogs.

Os primeiros posts do Blog do Cardoso, do Contraditorium e do MeioBit conjugavam performances adotadas, atualmente, em ambientes de sites de redes sociais mais populares. Antes da popularização do Twitter e do Facebook, percebemos que o blogueiro costumava publicar posts mais "enxutos" que privilegiavam o compartilhamento de conteúdos audiovisuais. À medida que esses ambientes conquistaram popularidade, Cardoso passa a fazer esse tipo de performance na sua conta no Twitter e, com isso, muda sua estratégia na elaboração de posts para seus blogs. No exemplo abaixo, podemos perceber um post com as características mencionadas:

\section{Simulador de tufas, publicado no Blog do Cardoso em 28/02/2006}

Site em flash de fabricante de sutiãs esportivos permite simular a movimentação das atetas, digo, atletas. Veja como ciência, veja como sacanagem. Dá no mesmo.

Link Direto do Contraditorium...

Como podemos perceber, o post em questão contém um link redirecionador para o site que Cardoso menciona no título.

Notamos que a descrição de sua persona digital é feita com base na demonstração de saberes e experiências relacionados aos principais assuntos abordados nos blogs dos quais participa: tecnologia, informática, cultura geek, por exemplo. Com isso, Cardoso define as temáticas com as quais se encontra familiarizado e, ao mesmo tempo, demonstra que possui habilidades que dão credibilidade a sua performance.

O seu interesse em ser somente blogueiro define uma posição sobre como elaborará seus conteúdos, considerando a intenção de que estes sejam pensados para ambientes digitais. Tendo em vista que blogs existem somente em ambientes digitais, e que o blogueiro define a persona a ser apresentada nesses suportes, 
logo podemos falar que os posts de Cardoso são pensados para se adequarem ao tipo de interação com base na publicação de comentários, por exemplo.

Cardoso, ao mencionar o seu interesse em ser somente blogueiro, acaba por demarcar a sua presença nos ambientes digitais que seus conteúdos circulam. A presença da palavra "blogueiro" na seção "Quem sou eu" é uma forma de definir que a sua atuação privilegia ambientes digitais. Além disso, o posicionamento de Cardoso percorre a cultura geek e, em alguns casos, acaba por reforçar estereótipos, notados em seus posts de tom reflexivo, quando admite certos comportamentos relacionando-os ao fato de ser um geek. Ainda, Cardoso assume a "tarefa" de compartilhar o seu conhecimento apurado e suas experiências com pessoas que têm os mesmos interesses que ele.

O blog Contraditorium é o segundo blog de Cardoso e foi criado em 2005. Os primeiros posts desse blog foram publicados inicialmente no Blog do Cardoso e, em seguida, foram transferidos para o Contraditorium. A partir de Fevereiro/2006 , os conteúdos do Contraditorium começam a refletir a proposta do blog. As postagens encontradas no Contraditorium apresentam digressões de Cardoso sobre os mais variados assuntos desde a área tecnológica ao universo dos filmes pornôs, passando por dicas e conselhos com base nos rumos dados a sua carreira de "blogueiro profissional".

No Contraditorium encontramos alguns posts que explicam como se comportar, o que os sites de redes sociais podem oferecer em termos de visibilidade, em uma tentativa de reafirmar o seu papel como uma persona "criada" em ambientes da Web. A postura de Cardoso, especialmente em posts deste gênero, é a de alguém em uma posição privilegiada, conhecedor dos mecanismos norteadores do funcionamento e da popularização de blogs e de páginas em sites de redes sociais.

O blog de tecnologia MeioBit surgiu em maio de 2004 e foi criado por Leonardo Faoro e Luiz Eduardo Nercolini. A participação de Carlos Cardoso começou em 30/03/2006 com um post intitulado "Download de séries não é crime". Seus conteúdos gravitam em torno de assuntos relacionados a pesquisas e aprimoramentos tecnológicos: tecnologia da informação, astronáutica e de astronomia, tecnologia bélica, só para citar alguns exemplos.

Os dados são, em grande parte, textuais. Alguns posts contêm conteúdos audiovisuais que complementam a parte escrita. Para a realização da análise, 
buscamos verificar o impacto das informações disponibilizadas por Cardoso, em seus blogs e posts, nas interpretações dos(as) comentaristas como forma de legitimação de sua persona digital.

A persona Carlos Cardoso, microcelebridade, depende de interações e de sua performance on-line, bem como do reconhecimento de suas audiências e de seus pares (BRAGA, A., 2009). O público se dirige ao blogueiro e, por meio dos comentários gerados, torna esses ambientes digitais relevantes. Por conseguinte, legitima-se a personalidade de Cardoso como enunciador de um discurso interessante para o grupo. As tecnologias de que dispõe são usadas com o intuito de tornar as informações disponibilizadas nos blogs acessíveis a um número maior de pessoas. A leitura de um blog requer um tempo maior e a sua configuração parece favorecer redirecionamentos para outros blogs e/ou websites e para perfis em sites de redes sociais, dando embasamento às ideias e performances contidas nos posts. Além disso, o(a) visitante pode procurar por posts antigos ou fazer uma leitura através das categorias de cada conteúdo.

As participações na seção de comentários dos blogs de Carlos Cardoso demonstram o que comentaristas pensam a respeito das performances do blogueiro. Assim, podemos inferir que essas informações legitimam Cardoso como microcelebridade, tendo em vista que o blogueiro se posiciona como o portador de um discurso que interessa a muitas pessoas. Além de expressar a opinião de seguidores(as) de Carlos Cardoso, esse discurso contribui para a popularidade do blogueiro, pois amplifica a voz presente nos posts. Os conteúdos de Carlos Cardoso podem ser refutados ou aceitos e, por conseguinte, essas reações colaboram para a fama de sua persona digital. Além disso, os comentários quantificam a popularidade e, em termos numéricos, refletem o sucesso de Cardoso.

No caso dessa pesquisa, o papel de enunciador é ocupado por Carlos Cardoso com o objetivo de informar e de gerar engajamento por parte das pessoas que acompanham seus blogs. No contexto dos ambientes digitais, o sucesso pode ser determinado pelo número de pessoas que acompanham seus conteúdos e, por conseguinte, legitimado pelas interações existentes nesses ambientes digitais. $\mathrm{O}$ engajamento é possibilitado por meio do post publicado por Carlos Cardoso, como mecanismo para a obtenção e para a manutenção de sua condição de microcelebridade. Os comentários gerados - e as performances que surgem a 
partir da performance original - dão credibilidade aos conteúdos de Cardoso e acabam torná-los referência no circuito-blogue em que a microcelebridade se encontra inserida.

A partir do momento que existem comentários deixados por outras pessoas nas publicações de Carlos Cardoso, existem interpretações acerca do post produzido. Essas interpretações podem renovar o posicionamento do blogueiro, pois os comentários refletem como os(as) comentaristas veem a performance de Cardoso enquanto expressam suas próprias opiniões dentro daquele contexto. Os comentários deixados são uma forma de verificar os diferentes grupos que interagem nesses espaços e como cada um se comporta nesses ambientes digitais.

Portanto, os(as) comentaristas dos blogs de Carlos Cardoso colaboram para disseminar as ideias contidas nos posts do blogueiro. Os pontos de vista apontados, bem como as reações expostas naqueles ambientes, atuam de forma a complementar a performance de Cardoso. Nesse sentido, esses indivíduos coenunciam o texto para outros(as) participantes, partindo do pressuposto de que pertencem a grupos, inseridos ou não na cultura geek.

Esses co-enunciadores podem ser analisados sob diferentes aspectos. Um deles é o entendimento da mensagem sob a perspectiva coletiva do circuitoCardoso. Outra possibilidade é a forma como eles interpretam o texto com base na forma pela qual Cardoso se apresenta. Ou seja, como eles veem a figura de Cardoso mediada pelo conteúdo publicado. O papel desempenhado por essas pessoas é o de reproduzir as ideias do blogueiro sob seu ponto de vista e, portanto, disponibilizar novos conteúdos que têm como referência os posts de Cardoso. Tal processo interfere na visibilidade e na amplitude que a persona digital de Cardoso pode vir a alcançar.

\subsection{Procedimentos Analíticos}

A nossa pesquisa compreende a análise de interações e de performances feitas por comentaristas dos seguintes blogs de Cardoso: Blog do Cardoso, Contraditorium e do MeioBit. A partir dessa análise, pretendemos verificar como a persona de Cardoso é legitimada pelas "vozes” de seus(suas) fãs e críticos(as), assim como a "fala" do blogueiro é reverberada nesses comentários. A análise foi 
organizada por meio de categorias discursivas, as quais emergiram da própria observação da dinâmica empreendida nesses ambientes.

Nesse sentido, encontramos quatro categorias de análise. São elas:

\author{
Carlos Cardoso: "Quem Sou Eu" \\ Circuito-Blogue de Cardoso \\ Audiência e Público como Valor \\ Práticas de legitimação pelo público e pelos pares
}

Tais categorias discursivas pretendem englobar as questões levantadas e que nortearam o desenvolvimento dessa pesquisa. Dentre as quais:

\footnotetext{
A persona digital de Cardoso reforçada sob a ótica de comentaristas; A cultura de grupo existente no circuito-Cardoso;

Um conselho de comentaristas mais próximos(as) de Cardoso que sempre apóia a performance do blogueiro;

A segregação de participantes "não-iniciados(as)" pelos iniciados(as);

$\mathrm{O}$ discurso de Cardoso reverberado ou criticado pelos(as) comentaristas.
}

O circuito-Cardoso possui um valor simbólico considerável, se levarmos em conta o número elevado de participações na forma de comentários e o reconhecimento de sua existência por outras microcelebridades. Dentre as quais, aqueles(as) com um maior número de participações são: Fabião Morróida (Portal do Macho); Cobra (Homem na Cozinha); Nospheratt (Blog da Nospheratt); Fabiane Lima (Megalopolis); Lu Monte (Dia de Folga); Nick Ellis (Digital Drops). Ainda que faça uso de estratégias que atraiam públicos bastante diversificados, Cardoso consegue legitimar-se como figura de destaque, tendo em vista que seus posicionamentos são reforçados mesmo em momentos de conflito.

As seções de comentários dos blogs compreendem um espaço no qual o público pode expor suas ideias acerca dos conteúdos publicados. Esses ambientes demonstram ser um objeto importante para se analisar as múltiplas compreensões geradas em torno de um discurso. Por conseguinte, tais compreensões acabam por esclarecer uma noção de discurso: aquela que o torna possível. Por meio do entendimento das ideologias que sustentam um enunciado, o discurso é construído e percorre diversos contextos e diversos públicos. Em nosso caso, os comentários nos ajudam a perceber como Cardoso é visto por seu público e como este se insere no discurso, por meio de seus comentários.

Os procedimentos para análise acompanham todos os comentários feitos nos posts selecionados. O objetivo pretende, inicialmente, identificar como as pessoas 
interpretam os posicionamentos de Cardoso pela mediação dos conteúdos publicados. Esse olhar, do ponto de vista do(a) comentarista, pretende identificar como o papel de Cardoso é desempenhado e como esse papel é interpretado por aqueles(as) que comentam seus conteúdos.

Além disso, pretendemos identificar as pessoas que comentam mais e como estas se encontram inseridas nesses ambientes. Essa inserção tem por base os modos de apresentação e os acordos tácitos aceitos no momento da entrada na participação do circuito-Cardoso. Ou seja, observaremos algumas indicações de como essa apresentação foi feita e como ela foi aceita pelos(as) membros(as) do circuito-Cardoso.

A lógica interacional desses ambientes será observada e os resultados obtidos pretendem ilustrar, sob o ponto de vista dos comentários feitos aos conteúdos de Cardosos, como ela se encontra apropriada por seus(suas) participantes.

$* * * * * *$

Na seção a seguir, apresentaremos a Análise do Discurso propriamente dita. Nesta parte, o trabalho mostrará uma parte dos dados analisados alocados em categorias analíticas. Como vimos, tais categorias são emblemáticas e caracterizam as performances e interações no âmbito do circuito-Cardoso. Apesar da especificidade encontrada nesse procedimento, percebemos que os resultados encontrados são aplicáveis a outros blogs e a outras microcelebridades, embora exista uma variação entre temáticas e de linguagens, por exemplo. Tal análise demonstra que o circuito-blogue sustenta a microcelebridade assim como caracteriza a sua persona digital, própria ao contexto em questão. 


\section{O Circuito-Cardoso: aspectos analíticos}

\subsection{O Eu e os Outros}

Carlos Cardoso possui um estilo peculiar de "blogar". Além das publicações refletirem a opinião do blogueiro, revelam elementos caracterizadores de sua performance on-line. Na maioria das vezes, os posts são elaborados com base em referências que revelam gostos pessoais ou, ainda, apelam para linguagens usadas por aqueles(as) que, como Cardoso, trabalharam/trabalham nas áreas de informática e de tecnologia da informação. Em alguns casos, ele aproveita-se de fatos e de notícias de grande repercussão, assim como aborda questões delicadas relacionadas à religião, política, homossexualidade. Além disso, costuma satirizar a preferência de alguns indivíduos para determinadas marcas e modelos de gadgets, softwares e hardwares. Nesse sentido, Cardoso gera debates acalorados nas seções de comentários dos posts em análise.

Os posts possuem características que reforçam a performance de Cardoso em ambientes digitais, refletindo posicionamentos e atitudes que o tornaram conhecido na blogosfera. Às vezes, esse estilo peculiar rende ao blogueiro a alcunha de "controverso", tendo em vista que seus posts são parciais, revelando explicitamente sua visão do mundo. Dentro do conjunto de comentaristas de Carlos Cardoso, há aqueles(as) que o admiram, tornando-se fãs fervorosos(as) de suas publicações. Há aqueles(as) que preferem discordar de suas ideias, revelando-se tão obcecados(as) quanto seus(suas) admiradores(as). Antes de expormos o que estes indivíduos pensam de Cardoso, achamos pertinente usar as palavras do próprio blogueiro em uma tentativa de encontrar elementos caracterizadores de toda essa controvérsia em torno de sua persona digital. Abaixo, selecionamos alguns trechos da seção “Quem Sou Eu”, publicada no Blog do Cardoso e com link no Contraditorium. 
[...] Carioca, solteiro, nascido em 1969, dois meses depois de Armstrong caminhar na Lua. Legítimo filho da Era Espacial, sempre gostei de tudo que tivesse a ver com tecnologia.

Assisti 2001 em uma reprise, saí do cinema com um par de orelhas enorme. Não entendi patavinas, mas adorei. Criado lendo Júlio Verne, só poderia dar nisso mesmo. Ganhei meu primeiro micro, um CP-200, no auge da Reserva de Mercado, uma época negra, digo, afrobrasileira, [...].

Continuei como micreiro (era esse o termo, bem melhor que "internauta") mas desviei minha atenção para outras áreas criativas. Fiz alguns cursos na Escola Superior de Propaganda e Marketing, e acabei prestando vestibular para Comunicação Social, mas confesso que o ambiente da Universidade Federal Fluminense não era o que eu esperava.[...]

Início da Vida Profissional

[...] Passei alguns anos trabalhando como enganador-high-tech até me decidir pela literatura. Escrevi onze livros, alguns best sellers na área técnica. [...] meu maior orgulho é ter escrito o primeiro livro sobre Palmtops do Brasil. Sou usuário de Palms quase de primeira hora, meu primeiro PDA foi um Palmpilot Professional (grifo do blogueiro) (tenho até hoje) comprado via Internet, numa época em que ninguém fazia isso. Nos últimos 5 anos me especializei em e-learning[...]. Hoje depois de 5 anos, acabou o tesão. Saí, pedi as contas, precisava achar um norte na minha vida, já que o sul não deu certo. Depois de muita contemplação, decidi investir meu know-how na Internet, mais precisamente nos blogs.

O objetivo era me tornar o primeiro blogueiro profissional do Brasil. Não desenvolvedorblogueiro, escritor-blogueiro, jornalista-blogueiro. Apenas blogueiro. Outras atividades que porventura apareçam complementarão os blogs, não o contrário.

GADGETS

Minha ligação com tecnologia vem quase de berço. [...] Com um modem de 1200bauds mandei minhas primeiras mensagens para a Digital Highway, depois fui membro do Unikey, terminando meus dias de BBSeiro na Infolink, já com um híbrido de BBS/Internet. Acompanhei o nascimento da telefonia celular, ainda estatal. [...] Minha relação com a tecnologia é entre amor e ódio. Ao mesmo tempo que alguns dos piores momentos de minha vida foram revelados por causa de tecnologia (e a incapacidade de 3os em utilizala de forma discreta) esses brinquedos me proporcionaram momentos maravilhosos. [...] O Futuro

2006 foi um ano dedicado aos blogs, completamente sabático. Devo dizer que foi muito (grifo do blogueiro)bem-sucedido, além das minhas expectativas racionais (as irracionais nunca são atingidas). O Contraditorium foi escolhido pelo IDG Now como um dos 10 blogs mais populares da Internet Brasileira, (grifo do blogueiro) estou tirando meu sustento dos blogs, tenho por volta de 20 mil visitantes únicos / dia e meu faturamento cresce quase $20 \%$ ao mês. [...]

Só lamento pelos que previram meu amargo fim. [...]

A necessidade de escrever um perfil descritivo em ambientes digitais parte do pressuposto de que é preciso revelar quem escreve os posts em um blog. $\mathrm{Ou}$ seja, existe a importância de dar um aspecto pessoal ao blog. De acordo com a temática apresentada nesses espaços, se constrói uma caracterização que evidencie as experiências ligadas aos assuntos, bem como as razões pelas quais motivaram a criação de um ambiente digital e as razões motivadoras das performances peculiares a esses espaços. Por essa razão, o perfil precisa elencar, de maneira objetiva, fases da vida daquele(a) que escreve e como estas se encontram encadeadas até a criação do blog. Por meio dessa edição de fatos, é constituída 
uma persona digital a qual se dirigirá a um público que deverá buscar, justamente, o que está nesse espaço.

Outrossim, ao notarmos a preocupação de Cardoso em elaborar uma seção que "apresente" a sua persona digital, percebemos o desejo do blogueiro de mencionar a legitimidade de um lugar de fala. Ou seja, ao definir referências fundamentais ao seu enunciado, Cardoso embasa seus posicionamentos e suas opiniões existentes, em grande parte, em suas performances on-line.

Portanto, reconhecemos que o perfil de Cardoso pretende revelar garantias e credenciais que o legitimam para falar sobre tecnologia, ciências, seriados ou qualquer outro assunto ligado à cultura geek, dentro do circuito-Cardoso. Com base nisso, Cardoso garante que, por meio desses saberes, ele pode atuar como "blogueiro profissional". Para tanto, Cardoso demonstra saber que suas publicações precisam: atrair visitantes; conquistar aqueles(as) familiarizados(as) com as referências usadas pelo blogueiro; chamar atenção daqueles(as) já legitimados(as) como microcelebridades e ser aceito por estes indivíduos; demonstrar o nível de conhecimento e de experiência em relação aos assuntos os quais se pretende abordar; assim como se posicionar como alguém que, por meio de suas performances e de suas interações, tem metas a serem alcançadas e preocupa-se com o conteúdo apresentado nos blogs nos quais publica seus posts.

Nesse sentido, o perfil é composto por uma linha do tempo na qual Cardoso relembra fatos desde o seu nascimento até os dias mais recentes. Esse panorama sobre a história de vida e a história profissional do blogueiro é alinhavado com as temáticas do blog, demarcando, ainda, como será o seu comportamento on-line. $\mathrm{O}$ blogueiro dá mostras de como tratará aqueles(as) que, segundo ele, não sabem lidar adequadamente com tecnologia ["Minha relação com a tecnologia é entre amor e ódio. Ao mesmo tempo que alguns dos piores momentos de minha vida foram revelados por causa de tecnologia (e a incapacidade de 3os em utiliza-la de forma discreta) esses brinquedos me proporcionaram momentos maravilhosos."].

O termo "blogueiro-profissional" pressupõe o acúmulo de um saber técnico e de experiências para lidar com o universo e a dinâmica dos blogs. Ao que parece, esse conhecimento é valorizado porque nem todos(as) blogueiros(as) gerenciam suas performances em ambientes digitais de modo a atrair e manter visitantes. Por conseguinte, ao adotar a postura de "blogueiro profissional", 
Cardoso se distancia dos(as) demais, pois pretende construir essa carreira profissional exclusivamente na área. A sua "boa vontade" de compartilhar esses saberes e experiências coloca Cardoso em uma posição de destaque, tendo em vista que seus(suas) visitantes esperam um retorno que comprove o valor das credenciais apresentadas pelo blogueiro. Por sua experiência desde os primórdios da informática no Brasil, isso daria legitimidade a Cardoso e, ainda, conhecimento sobre o funcionamento dessa área e como as pessoas se comportam nesses ambientes. Por deter este conhecimento, Cardoso não aceita ser ser questionado por sua performance on-line.

Cardoso, como boa parte dos(as) geeks ${ }^{29}$, tem a preocupação de especificar modelos e características dos equipamentos tecnológicos que possuiu/possui. Ao mencionar tais características e, especialmente, as experiências tidas com esses gadgets, o blogueiro assume uma postura de conhecedor e de desbravador, interessado em saber como as coisas funcionam e em exibir, consequentemente, esse conhecimento. A demonstração pública de conhecimento é uma das características mais emblemáticas de geeks, especialmente daqueles(as) ligados à área de tecnologia. Além disso, ao longo do texto, notamos referências a ícones da cultura geek, como a literatura de Julio Verne, o filme 2001: Uma Odisséia no Espaço, Star Trek, bem como a forma sarcástica de Cardoso fazer humor.

O encerramento da seção revela o reconhecimento de suas performances e de suas interações, remetendo às informações expostas anteriormente. Neste ponto, o blogueiro menciona o reconhecimento de mídias de massa e a popularidade alcançada por seus blogs na blogosfera. Além disso, Cardoso termina a construção de seu perfil assumindo uma postura de alguém que, supostamente, não liga para críticas. Nas entrelinhas, podemos notar uma postura de alguém mal-compreendido e sempre alvo de críticas. Percebemos que essa breve crítica se dirige às pessoas que se encontram segregadas do grupo de seguidores(as).

- $\quad$ Cardoso e suas Opiniões

Na seção "Quem Sou Eu", vimos como os posicionamentos assumidos por Cardoso durante suas performances são legitimados pelas experiências

\footnotetext{
${ }^{29}$ Para maiores detalhes sobre a cultura geek, veja o capítulo "Cardoso, seus blogs e a cultura geek".
} 
acumuladas pelo blogueiro. Entretanto, precisamos observar como as performances de Cardoso são vistas pelos(as) comentaristas dos blos em análise. Nesse ponto, identificaremos a postura do blogueiro enquanto comentarista de seus posts, na tentativa de justificar seus próprios posicionamentos e opiniões. Ao expor sua opinião, Cardoso reforçaria o que ele apresentou quando definiu o seu lugar de fala e como se dirigiria a seu público. Por esse motivo, achamos necessário observar o blogueiro nos momentos nos quais sustenta os posicionamentos e opiniões relatados na seção "Quem sou Eu" e em interações observadas nas seções de comentários dos posts analisados.

Nos dados a seguir, encontraremos exemplos de assuntos que chamam a atenção de Cardoso e, também, dos(as) visitantes de seus blogs. Geralmente, a participação de Cardoso pretende ampliar e justificar as ideias abordadas inicialmente nos posts geradores de comentários.

Post 1: Ou dá ou desce, Bispo Macedo, publicado no Blog do Cardoso em 01/12/2005 - 1.181 comentários

Jesus está vo. 316 weeks ago

Aí Cardoso, à quanto tempo você está com este site na internet querendo acabar com a igreja universal?

Tenho certeza que você não conseguiu nem meio \%. Desiste, cardoso, você não é maior que o poder de Jesus.

Cardoso 316 weeks ago

Eu não tenho esperança de acabar com a universal, a quantidade de idiotas como você que caem nas garras deles é grande demais.

De resto sou muito mais eu do que seu amiguinho imaginário.

Post2: Aviso aos crentes idiotas: Vocês serão banidos daqui, publicado no Blog do Cardoso em 21/08/2007 - 88 comentários

Cardoso. 282 weeks ago

Luteranos, Batistas, Presbiterianos? Estou pra ver o dia em que um desses vai encher o saco de alguém.

Um dos meus grandes amigos durante a adolescência se chamava João Batista (já viram, né?) e NUNCA, NUNCA encheu o meu saco ou de ninguém na turma pq a gente saía, bebia, zoava. Ele não bebia, não fazia tanta besteira, mas não recriminava ninguém, nem era recriminado por não exagerar como nós. Se alguém aparecesse chamando de "crente carola", era porrada coletiva, posso garantir.

Eu inclusive ajudei várias vezes a editar o jornalzinho da igreja dele, o "Misto Crente", que acabou pq um pastor babaca achou o nome "desrespeitoso".

Os ideais básicos do cristianismo são legais? São. Da mesma forma que os dos Jedis. Ambos respeitam a Regra de Ouro. Não me importa se ambos pra mim são pura ficção, prefiro alguém seguindo-os do que explodindo prédios com aviões.

Post3: Quem quer ver as fotos dos corpos do acidente da gol?, publicado no Contraditorium em 06/10/2006

Tatiana 326 semanas atrás

Oi Cardoso, 
gostei muito do que escreveu.

Bom eu realmnete tenho interesse em ver as fotos, pois estou me formando em Medicina, então de uma forma ou de outra terei que ver.

Mas acho muito terrível as pessoas que por curiosidade, pedem as fotos a todo instante.

[...]Mais infelizmente na internet é tudo assim como você escreveu.

Tenha uma Boa noite!

Cardoso 322 semanas atrás

Às polyanas de plantão que ainda acreditam na humanidade, o que me dizem dos abestados que NẪO lêem NADA do que eu escrevi e postam comentários pedindo os vídeos?

Tatiana, mude pra veterinária, você não quer realmente se formar pra cuidar dessa gente... $:($

Post4: Atendendo a pedidos - mais ou menos, publicado no Contraditorium em 03/12/2008 - 109 comentários

Eduardo. 215 semanas atrás

Não entendo esses ânimos exaltados que as vezes surgem em "discussões" na internet... Alias, talvez seja porque aqui as pessoas comecem à criar personalidade uma personalidade diferente. Tanto que é difícil imaginar essas discussões tomando esse rumo estando "frente a frente".

A única coisa que dá pra ter certeza é que quem entra nessas discussões deixa a racionalidade de lado bem no início, porque depois o que importa pra ele é sair por cima. [...]

Cardoso 214 semanas atrás

É muito triste ver que o conceito de anarquia é mal-entendido. Vocês precisam pensar mais como o Curinga...

Post5: Brasil e Moçambique vão cooperar no desenvolvimento científico, publicado no MeioBit em 25/11/2008 - 396 comentários

Mario Gentil $\bullet 4$ anos atrás

A matéria fala apenas de um acordo bilateral de cooperação. Nâo diz que não há ou haverá outros acordos bilaterais, ou que a cooperação com Moçambique é prioritária em relação a qualquer outra.

Infelizmente, o autor do post se deixou levar pela paixão político-partidária ao escrevê-lo.

Este blog é ótimo quando se atém objetivamente a questões tecnológicas.

[...]

Carlos Cardoso $\rightarrow$ Mario Gentil $\bullet 4$ anos atrás

Mesmo que a cooperação custasse $\mathrm{R} \$ 10,00$ já seria dinheiro jogado fora, e o acordo é ruim independente do governo que o fechou, embora populismo terceiro-mundista seja especialista dos petralhas...

Post 6: GVT anuncia GVT TV e miraculosamente foge do mais do mesmo, publicado no MeioBit em 16/09/2011 - 256 comentários

Fábio Fialho • um ano atrás

Tenho Sky HD com HBO, SexyHot grátis, todos Telecine e mais uma cacetada desses canais que são "premium" por 75 reais mensais. Não paguei nada pelo meu decodificador.

Que tal, GVTTV?

ps. Isso no interior do Maranhão.

Que tal, GVTTV? (1)[...]

Fábio Fialho $\rightarrow$ RutêncioOK $\bullet$ um ano atrás

É exatamente como o @Dragonball disse, com uma diferença pequena de preço.

Comprar o plano mais foderástico da Sky, colocar canais extras e etc.

Aí você divide os pontos com amigos. É 285 e temos 4 pontos, então ficou 71 pra cada.[...]

Carlos Cardoso $\rightarrow$ Fábio Fialho • um ano atrás

Mentira. Você compartilha ilegalmente sua sky, como confessou aqui.[...] é canalhice dividir por baixo dos panos e usar esse valor como comparatativo. 
Como autoridade máxima dos blogs nos quais publica conteúdos (somente o Blog do Cardoso e o Contraditorium foram criados pelo blogueiro), Cardoso precisa reforçar constantemente as posições assumidas por sua persona digital. A definição de sua persona digital aparece de forma mais objetiva na seção "Quem sou Eu", publicada inicialmente no Blog do Cardoso, mas também ao longo dos posts selecionados. Ao expressar suas opiniões, na forma de comentários, notamos que Cardoso tenta ampliar a ideia contida inicialmente no post ou defender um ponto de vista que, presente em uma thread, foi contrariado ou deturpado pelos(as) comentaristas participantes.

Nesse momento, o comentário de Cardoso corrobora a sua performance online e é uma forma de reforçar a sua posição e o lugar de sua "fala". Não chega a ser uma explicação sobre a sua abordagem, sobre as piadas, sobre ironias ou sarcasmos. Na verdade, o blogueiro busca escrever, de forma complementar, sobre o que ele pensa, reforçando posições e expondo suas opinões sobre o assunto.

Ao expressar seus pontos de vista, Cardoso revigora seus pensamentos e demonstra que a sua opinião vale mais exatamente pela posição que ocupa dentro do circuito-Cardoso. Quando se manifesta, Cardoso coloca-se como alguém que pretende levar esclarecimentos a seu público, seja na forma de descobertas, notícias ou fatos revistos, sob a ótica de alguém que está em uma posição privilegiada. Essa distinção pressupõe um conhecimento amplo e, de certa forma, um discernimento sobre os tópicos abordados nos posts. Embora alguns comentários, nessa categoria, apresentem-se contrários aos posicionamentos de Cardoso, percebemos que a atitude adotada, na ocasião, reforça a sua condição de "conhecedor e desbravador" que apresentará novos saberes a seus(suas) leitores(as). Nesse sentido, notamos um cuidado para manter o encadeamento de pensamentos e de opinões nos comentários observados.

O comportamento de Cardoso, no momento em que faz interferências desse tipo, relaciona-se à pretensão de prestar um "serviço de utilidade pública" dentro do circuito-Cardoso. Ao adotar essa postura, o blogueiro precisa incorporar o papel de quem está ali para "ajudar" suas audiências. Portanto, Cardoso assume uma postura menos agressiva, embora não abra mão de suas ideias e de seus posicionamentos. 
Além do "serviço de utilidade pública", nessa categoria percebemos características da personalidade de Cardoso explicitadas por meio de seus posts e de suas participações em forma de comentários. Ao desempenhar uma performance de problogger, Cardoso parece ter a intenção de mostrar como ele é e o que ele pensa a respeito de determinados assuntos, demonstrando estar ciente do que ele aborda e escreve em seus posts.

Ao expressar suas opiniões, na tentativa de justificar os modos pelos quais trouxe à tona determinados assuntos, Cardoso tenta se manter coerente em suas performances e interações. Esse nível de coerência está ligado tanto às colocações expostas na seção "Quem sou eu" quanto a performances e interações realizadas em outros ambientes digitais, como suas páginas em sites de redes sociais. É uma forma de dar unidade à sua atuação e, dessa forma, tornar-se conhecido justamente por característica definidoras de sua persona digital: geek, exprofissional da área tecnológica, apelo a sarcasmos em seus posts, por exemplo. Por essa razão, alguns de seus posts contêm links e referências a outros posts que abordaram temáticas semelhantes, como forma de dar unidade a sua performance.

Por outro lado, ao assumir essa postura, notamos, ainda, uma forma de gerenciar seus espaços digitais. Primeiramente, publica-se opiniões as quais definem a postura de Cardoso. Consequentemente, é gerado um fluxo de comentários, com considerações favoráveis ou não. A dinâmica observada, nessa categoria, determina como Cardoso gerenciará tanto sua prória performance quanto a performance de comentaristas, mostrando como certos assuntos são tratados sob perspectiva do blogueiro. Ao adotar esse posicionamento, Cardoso abre margem para as segregações de público, que serão abordadas mais adiante. Ou seja, ainda que implicitamente, o blogueiro define o público para o qual se dirige.

\section{- $\quad$ Elogios, Críticas e Sugestões}

Comentaristas costumam recorrer a elogios, críticas ou sugestões para iniciarem suas participações em seções de comentários de blogs. O elogio, usualmente, parece ser uma forma de apresentar-se naquele ambiente e iniciar a sua participação no referido circuito-blogue (BRAGA, A., 2008a).

No caso do Blog do Cardoso, do Contraditorium e do MeioBit, os elogios, as críticas e as sugestões parecem funcionar como uma medida para avaliar a 
proximidade e o conhecimento do(a) comentarista em relação ao assunto tratado por Cardoso.

Os comentários escolhidos reúnem elogios, críticas e sugestões de comentaristas que, na tentativa de receberem atenção do blogueiro, apelam para performances e interações demonstradas anteriormente no circuito-Cardoso que caracterizam a postura de Cardoso em seu próprio circuito. Essa postura, dependendo do ponto de vista, pode ser reconhecida ou repelida.

Post1: Ou Dá ou Desce, Bispo Macedo, publicado no Blog do Cardoso em 01/12/2005 - 1.181 comentários

Célio 310 weeks ago

Sabe qual é o seu problema Cardoso? Você se acha muito esperto. Quem te viu nos tempos acadêmicos e te vê hoje...Você não tem moral para denegrir a imagem de ninguém. Nem a do Edir Macedo. Para mim não tem ética alguma quando escreve nessa sua porcaria de BLOG algum palavrão. Aprenda primeiramente a ser gentil. Só porque é um jornalista fracassado não quer dizer que possa machucar outras pessoas.Até hoje não sei se é jornalista ou publicitário, se fala o que aconteceu ou inventa os acontecimentos para se vender de inteligênte. Não fique chateado mas lutar com quem é mais fraco é coisa de covarde.

Cardoso 310 weeks ago

Quem me viu nos tempos acadêmicos sabe que eu não mudei uma palha, então pare de blefar, "irmão".

E se não tenho moral pra falar mal do Macedo, putaquepariu (a porcaria de blog é meu, falo o que quiser) então devo estar bem mal.

Não sabe nem se eu falo ou invento? Não sabe se sou jornalista ou publicitário? Pombas, você não sabe de absolutamente nada... COMPANHEIRO LULA QUE HONRA VOCÊ LENDO MEU BLOG!!!!

Post2: Exclusivo: As fotos do acidente do vôo 1907 da Gol de dentro do avião, publicado no Blog do Cardoso em 26/10/2006

Reginaldo Fialho 319 weeks ago

Cardoso!

Está ficando sensacional! Ainda mais agora que os envolvidos estão também aparecendo. Finalmente uma mistura de algo que o Manson JÁ FEZ muito bem com inteligência...

Um tapa com luvas de pelica em muita gente que tá chegando até aqui!

Forte abraço,

Naldo - leitor assíduo, comentarista eventual

Post 3: Responda rápido: Isso aconteceria na Suécia?, publicado no Blog do Cardoso em 27/11/2008

Tebald. 210 weeks ago

Você pode fazer um post intitulado "Responda rápido: se o Cardoso morasse na Suécia, ele iria usar seu falso moralismo para reclamar do que?".

Não sou de entrar no blog dos outros para reclamar, mas esse post realmente está um lixo!

Enquanto pessoas estão sem suas casas, sem roupas para vestir e sem comida e sem noticias de seus familiares, vem um blogueiro que não sabe mais o que falar e resolve criar caso em cima das ações de desabrigados e vitimas de tragédias. Ai vem os seguidores de São Cardoso e resolvem também que "aquele povinho brasileiro de SC não merece nossa ajuda, ao invés de ajudar vamos criticar, vamos botar lenha na fogueira".

Esse tipo de comentário preconceituoso desmotiva as ações de ajuda, e aquelas pessoas realmente precisam de ajuda, inclusive o cara que está roubando a cerveja! 
Abra a cabeça senhor Cardoso e dê uma olhada no mundo a sua volta, onde um post desses pode lhe render alguns trocados e uns elogios dos seus puxa-sacos, mas no mundo real, pode ocasionar apenas que alguém necessitado deixe de receber um punhado de comida ou um agasalho.

Post4: Haiti - terra amaldiçoada por Deus, publicado no Contraditorium em $13 / 01 / 2010$

Alan Noda 156 semanas atrás

Olha Cardoso, o problema não é fazer piadas sobre questões políticas ou desgraça de um povo, pois o humor é a forma mais sagaz de se criticar quem está no poder administrando mal dinheiro alheio, seja na recuperação de catástrofes ou enfiando dinheiro dentro da meia.

Agora fazer comentários impertinentes ou piadinhas no twitter sobre a médica sanitarista Zilda Arns aí já é demais. Claro que você não vai conhecê-la sempre atrás do seu computador sentado nesta cadeira confortável, só conhece a realidade atrás da tela de computador, notícias sensacionalistas e fofocas, porque trabalho beneficente não dá ibope, nem dinheiro na internet, então é melhor se informar ou levantar da sua confortável cadeira, e ajudar ao próximo ao invés de criticar achando que é hipocrisia! Ajude o Fundo da Pastoral da Criança!

Post 5: Por favor, não matem os meus heróis, publicado no Contraditorium em 25/01/2011

João Roberto 98 semanas atrás

Clap, clap, clap...

Excelente post. Impressionante Cardoso como você consegue buscar detalhes referenciais para uma contestação ou analagia. Muito bom mesmo.

Esta psicóloga deve ser mais uma idiotizante na maldita linha dos politicamente corretos.

Post 6: Brasil e Moçambique vão cooperar no desenvolvimento científico, publicado em 25/11/2008 no MeioBit

Freddy Liverpool $\bullet 4$ anos atrás

Sinceramente em matéria de tecnologia Cardoso tem até algumas coisas úteis, mas em se tratando em matéria de política e relações internacionais esta ironia e superficialidade chega a ser uma decepção.

Não sou o Jonny Walker, mas walk mais que ele...

UranoTienn $->$ Freddy Liverpool $\bullet 4$ anos atrás

Mas cara, ele ate tem bons momentos, mas a maioria é feita de sarcasmo fraco.

Todos os seus posts que fogem da tecnologia tem visões extremamente infantis.

Chega a ser engraçada a diversidade do Meiobit, tem o cara da fotografia, o cara mais tecnico, a menina apple, o que posta um pouco de tudo e o bobo da corte entre outros.

Post 7: GVT anuncia GVT TV e miraculosamente foge do mais do mesmo, publicado no MeioBit em 16/11/2011

Douglas João Magalhães • um ano atrás

OLÁ, Juro que não conhecia seu blog, opa, agora vi lá no endereço, já tinha visto sim, mas não prestei atenção como devia ter feito!

Então, primeiramente, adorei seu texto! não só o texto escrito mas as coisas em volta dele tb! gostei mesmo!

Segundamente, em relação à matéria: Li outras coisas por aí tb sobre essa TV da GVT, e achei muita evolução, mas tem um gravíssimo retrocesso, acho q até a Oi-DocBrown deve rir disso, que é essa coisa de "alugar decoder", e principalmente o decoder que faz a principal função da novidade oferecida, o TIVO tunado.

Feio, feio, feio GVT! Pô, qualquer tv a gato grava no 'pêndráiv' do praraguai!

Mas, eu vou querer mesmo assim! 
Os elogios e críticas dão contorno às características da persona digital de Cardoso. São pontos que, dependendo de qual lado o(a) comentarista esteja, ajudam a compor a performance de Cardoso em seu circuito-blogue, enaltecendo o blogueiro ou depreciando suas atitudes. Os críticos ressaltam o estilo controverso de Cardoso blogar, enfatizando, por diversas vezes, que suas referências não dizem coisa alguma, que o seu sarcasmo é fraco e, ainda, está sempre em busca de polêmicas para aumentar suas audiências. Por outro lado, seus(suas) defensores(as) acompanham as produções de Cardoso justamente pelo fato de o blogueiro reunir essas características peculiares e assumir-se como alguém com opiniões bastante definidas.

Como podemos notar, os elogios apelam para referências contidas nos posts, como forma de expressar que as piadas, os sarcasmos, as ironias, bem como as referências, foram entendidas pelo(a) comentarista. $\mathrm{O}$ elogio torna-se uma forma de mostrar que o(a) comentarista pode ser considerado(a) parte do grupo que acompanha e defende a postura do blogueiro.

Os elogios acabam, também, por se estender às diretrizes e parâmetros que orientam os blogs nos quais Cardoso publica seus posts. Notamos que elogios são específicos, pelo fato de que a proposta dos blogs, como Cardoso deixa claro em alguns posts, é a de estimular um debate e não simplesmente uma publicação de elogios e críticas. Talvez, diante dessa exposição por parte do blogueiro, o comportamento dos(as) comentaristas seja direcionado a fazer elogios e críticas que privilegiem opiniões próprias acerca do que está contido nos posts.

Por sua vez, as críticas apelam para pontos polêmicos abordados nos posts de Cardoso. As questões controversas relacionam-se com o estilo parcial do blogueiro ao expressar seus pensamentos acerca de assuntos que envolvem religião, comoção pública em tragédias e, até mesmo, a escolha de equipamentos, marcas e sistemas operacionais na área tecnológica. Nesse sentido, os(as) comentaristas buscam mostrar que o ponto de vista evidenciado por Cardoso não é único e está, quase sempre, apoiado por uma postura "sensacionalista". Esse comportamento, sob a perspectiva desses(as) comentaristas, geram discussões inflamadas sem o propósito de elucidar o que foi abordado no post. 
Em contrapartida, a corte de $\operatorname{Cardoso}^{30}$, assim como o próprio, respondem a essas opiniões como se estas fossem resultado de uma leitura inadequada do post ou de uma interpretação equivocada do que seria o ponto de vista demonstrado pelo blogueiro. Essa alegação, feita por comentaristas e por Cardoso, diz respeito ao fato de que o blogueiro costuma apelar para ironias e referências com as quais nem todos(as) estão familiarizados(as).

Outrossim, as críticas insinuam a manipulação de informações da parte de Cardoso, para que o post fique atraente para mecanismos de busca e para a geração de comentários polêmicos, aumentando as audiências para os blogs. $\mathrm{Na}$ blogosfera, esse tipo de manipulação é condenada e alvo de críticas por parte daqueles(as) que frequentam/frequentaram os blogs de Cardoso. Entretanto, em alguns momentos, parece ser esse o interesse do blogueiro: de se tornar conhecido por esse tipo de performance, imprimindo a sua personalidade nos ambientes digitais dos quais participa. Em outros momentos, podemos notar como Cardoso se coloca como alguém que faz uso desse tipo de técnica, pois o seu objetivo é auferir renda por meio de seus blogs. Na blogosfera, boa parte dos(as) blogueiros(as) assume uma posição livre perante as mídias de massa e, por essa razão, não mudariam seus conteúdos com o objetivo de ganhar dinheiro. Ironicamente, Cardoso expõe claramente seu interesse de ser um problogger, como poder ser verificado na seção "Quem sou eu".

Os elogios e as críticas revelam os diversos públicos que compõem o circuito-Cardoso, como resultado de suas táticas para atrair audiências. Ao partir para esse tipo de apelo, Cardoso atrairia pessoas que não concordam com suas opiniões, gerando, portanto, os debates com o quais o blogueiro conta em suas seções de comentários como forma de provar a sua popularidade.

Diante da posição que ocupa, Cardoso controla as críticas e, ao fazer isso, adota uma postura radical e controversa. Em alguns momentos, o blogueiro demonstra não gostar de ser contrariado e justifica essa atitude afirmando que as críticas não são bem fundamentadas e os argumentos são fracos e facilmente derrubados.

De certa forma, tanto elogios quanto críticas revelam características da persona digital de Cardoso. No momento de uma crítica, tais características

\footnotetext{
${ }^{30}$ Para maiores detalhes sobre a corte de Cardoso, vide a seção "A Corte de Cardoso: Valores e Hierarquias".
} 
apelam para o lado autoritário, composto de momentos de arrogância e de pouca sensibilidade. Por outro lado, os elogios se direcionam para as qualidades apresentadas para o público como sendo parte de diretrizes e parâmetros orientadores da produção de posts do blog.

Para os(as) críticos(as) da postura de Cardoso, percebemos a preocupação de enfatizar que o blogueiro somente assume tais posicionamentos porque "atua" em ambientes digitais. A partir desse ponto de vista, esses(as) comentaristas realçam o estereótipo de pessoas que frequentam fóruns de discussão, chats e outros ambientes digitais nos quais se possa publicar algo ou estabelecer uma interação entre os(as) participantes. Esses estereótipos, especialmente os observados nas críticas, descrevem Cardoso como alguém que adota a postura de "crítico", "arrogante" ou "valentão" somente em ambientes digitais. Portanto, segundo esses(as) comentaristas, a postura de Cardoso - e a sua persona digital não seriam viáveis fora da Web.

\section{- $\quad$ Comentaristas assumem de onde falam}

Os posts de Cardoso costumam conter referências, algumas das quais bastante sutis, que apelam para o nível de conhecimento de seus(suas) visitantes sobre o assunto abordado. Esse estilo peculiar de tratar uma temática torna a performance de comentaristas mais ostensiva, tendo em vista que estes(as) precisam demonstrar que captaram e interpretaram adequadamente a mensagem publicada por Cardoso. Uma das formas de aproximar-se do grupo que compreende tais referências é observada quando o(a) comentarista assume de onde fala.

Dizer de "onde se fala" parece ser algo de suma importância dentro do circuito-Cardoso. Essa postura é observada quando comentaristas, para dar embasamento a suas opiniões, relatam experiências pessoais e/ou profissionais ou, ainda, algum fato que o(a) coloque em um nível de conhecedor(a) e/ou desbravador(a) do assunto. Nesse sentido, percebemos o interesse em alinhar-se à performance de Cardoso, tendo em vista que o próprio blogueiro atua dessa forma.

Post 1: Ou dá ou desce, Bispo Macedo, publicado no Blog do Cardoso em $01 / 12 / 2005$ 
Obreiro: Marcos. 342 weeks ago

Bom eu sou obreiro a igreja universal a 5 anos conheso todas as transações da igreja [...] sei que isso é mentira das mais mal lavadas e outra nada foi provado comtra o bispo macedo e se a igreja não fosse de deus não creceria a e até fasso um convite pra vcs irem na igreja universal mais proxima [...] Atensiosamente um obreiro que da oseu dizimo e suas ofertas para iurd Matheus!!!

Post 2: Vegetarianos, vejam o que lhes espera, publicado no Blog do Cardoso, em 16/12/2009

Fláviodiominus. 161 weeks ago

Eu sou Vegetariano ha mais de $\mathbf{1 0}$ anos, foi a melhor coisa que ja fiz na vida, faz bem pra mim, pros animais e pra minha consciência. Essas trocas de farpas entre vegs e não vegs é tão cansativa que nem me envolvo mais. [...]

Post 3: Haiti - terra amaldiçoada por Deus, publicado no Contraditorium em $13 / 01 / 2010$

Willow. 151 semanas atrás

[...] Mas, não saber que existe Haiti [...] e ou sua colonização, bem, aparece-me, no mínimo, ter faltado na escola. Não saber quem é Zilda Arns (ou nunca ter ouvido falar), provavelmente é uma falta de interesse total por quem faz bem ao país. Resumindo, você pode até tirar "onda mesmo", mas saiba uma pouco para fazer isto, afinal, "A IGNORÂNCIA e a FALTA DE CAPACIDADE de interpretação (na aula de história e geografia) do brasileiro me mata", e a mim tbm.

T.U. 150 semanas atrás

A realidade do brasileiro é outra. Eu dou aula em colégio particular e sei exatamente do que estou falando. [...] A maioria sabe que existe BBB-10, quem é cada um dos participantes, mas desafio você a perguntar a esmo quem é Zilda Arns. Eu duvido que você consiga.

P.S.: releia o comentário, não falo de mim, coloquei o verbo na terceira pessoa do plural pra generalizar, entendeu?

Post 4: Por favor, não matem os meus heróis, publicado no Contraditorium em 25/01/2011

Silvio M. 98 semanas atrás

[...]Gosto de jogos violentos desde o primeiro e saudoso DOOM, até chegar nos Call of Duty de hoje, mas não tenho coragem de matar nada, por menor que seja.[...]

Post 5: O Stallman está certo: Programa tem que rodar na máquina, publicado no MeioBit, em 23/11/2007 - 99 comentários

Ide Oce $\bullet 5$ anos atrás

Há muitos anos eu usava o e-mail gratuito do usa.net como e-mail principal. Bem, um dia eles resolveram cancelar o serviço e eu fiquei sem meus e-mails. Depois disso eu não confiei mais em serviços online. Utilizo quando necessário, mas não deixo minha vida depender deles.[...]

Post 6: Linux atinge a marca histórica de 1\% do mercado, publicado no MeioBit, em 20/05/2009

Vinicius_Espada $\bullet 4$ anos atrás

[...]Gosto do kurimin, do ubuntu... E já usei fedora e slackware. Linux é otimo sistema operacional e tenho na minha hd no dual boot com windows $x p$, mas ainda falta muito para eu largar a microsoft e me juntar a galera. Idealismo e open source não pagam meu salário. usar programas eficientes e confiáveis, sim. 
Saber exatemente o que está falando parece ser a tônica dos comentários em que seus(suas) criadores(as) compartilham experiências vivenciadas por eles(as) mesmos(as) ou por conhecidos(as). Entrar em uma discussão, defendendo um ponto de vista, pode ser facilitado por meio da menção do lugar ocupado pelo(a) comentarista a partir dos assuntos tratados por Cardoso nos posts ou pelos(as) demais comentaristas.

O lugar da fala é um fator determinante para evitar a rejeição ao comentário, mesmo quando se contraria o blogueiro e seus(suas) seguidores(as). Por essa razão, percebemos que, adotando esta estratégia, o(a) comentarista adquiriria o direito de expor suas opiniões. Para os(as) seguidores(as) de Cardoso, assumir de onde se fala é uma tentativa de conquistar um espaço privilegiado entre os(as) membros(as) da "corte de Cardoso". Como boa parte dos enunciadores, o blogueiro é imitado em suas performances por seus (suas) fãs e, mesmo, por aqueles(as) que, no intuito de confrontar a opinião de Cardoso, tentam mostrar a legitimidade de outros pontos de vista. Parece-nos uma tentativa, por parte destes últimos, de "derrubar" o oponente em questão usando os mesmos artifícios deste último. A imitação, nessa categoria, ocorre quando comentaristas apresentam, tal e qual Cardoso, suas credenciais que "autorizam" falar sobre as questões abordadas a partir dos posts.

Para o(a) comentarista, assumir de onde de fala é uma forma de dar legitimidade a sua abordagem e tornar o seu depoimento aceitável. Por essa razão, percebemos comentários descrevendo experiências profissionais e pessoais, como forma de mostrar conhecimento teórico e prático dentro dos assuntos abordados nos posts e nas threads dos comentários. Além disso, questionar a validade de uma afirmação como esta, em que se abordam experiências de vida, parece ser mais difícil.

Percebemos que esse tipo de atitude revela-se como um mecanismo de garantir uma paridade junto a Cardoso, no que concerne à elaboração de argumentos - favoráveis ou não - às ideias do blogueiro. Ou seja, ao dizer de onde se fala menciona-se o vínculo com os tópicos abordados.

Assumir de onde se fala, como podemos perceber, é uma forma de inserir-se na situação não apenas como um(a) mero(a) comentarista, mas como conhecedor(a) e/ou desbravador(a) da causa. Isso revela um aspecto especial para 
aquele(a) que comenta, tendo em vista que o(a) colocaria entre os pares ou capacitaria o(a) comentarista para a crítica apresentada.

Expor de onde se fala nos revela, portanto, uma forma de reconhecer-se no assunto abordado, inserir-se nas interações e conquistar respeito dos(as) demais participantes do circuito-blogue de Cardoso.

\section{- $\quad$ Tentando receber atenção de Cardoso}

O circuito-blogue de uma microcelebridade, como Cardoso, possui uma visibilidade relativamente grande. $\mathrm{O}$ seu sucesso é avaliado com base nos relacionamentos que estabelece com outras microcelebridades, no número de visitantes em seus blogs e páginas pessoais em sites de redes sociais e, ainda, pela atenção recebida das mídias de massa e mídias digitais. Por essa razão, parece natural que comentaristas tentem divulgar seus próprios blogs no circuitoCardoso. Por ser uma figura com uma performance peculiar, observamos algumas táticas usadas por comentaristas para divulgação e, ainda, na tentativa de receber alguma atenção de Cardoso.

Post 1: Aviso aos crentes idiotas: Vocês serão banidos daqui, publicado no Blog do Cardoso em 21/08/2007

Ivan Almirante. 277 weeks ago

Olá, Cardoso! [...]

Não quero usar o seu comentário -- que sei que é muito visitado-- para fazer jabá do meu blog, por isso não colocarei link de um texto aqui. Mas depois, caso queira, dê uma lidinha no texto que tem nele chamado ironicamente "Porque eu gosto da "igreja universal"!". O texto é de Eduardo Sampaio, um lingüísta, não é meu, portanto, mas vale a pena ser lido. Um abração, cara! Tenha uma ótima semana.

Post 2: Imagens exclusivas: terremoto no Haiti, publicado no Blog do Cardoso em $01 / 12 / 2010$

Dionísio 151 weeks ago

Excelente! Deste-me a inspiração de que precisava para o meu próximo post. Já agora, adorei o blog, fazem falta mais assim dedicados ao humor de mau gosto. E se gostas desse tipo de humor dá um saltinho ao meu quando não tiveres nada melhor para fazer.

Bom trabalho!

Post 3: Controle de zoonoses não protege o seu bichinho - eu adorei, publicado no Contraditorium em 13/01/2009

Selma. 203 semanas atrás

Hahaha! Excelente relato! Você fez muito bem!!! Conheco um caso parecido, que aconteceu com uma amiga de uma amiga. [...] Tomei a liberdade de republicar esse seu excelente post no meu blog www.lordcao.blogspot.com, com os devidos créditos, lógico!

Post 4: Por favor, não matem os meus heróis, publicado no Contraditorium em $25 / 01 / 2011$

Gilson Ricardo. 98 semanas atrás 
Cardoso, pegando o bonde da história do Xerxes, gostaria de indicar um artigo do meu

blog, que pouco tem haver com seu post, porém, acho que ficou bacana.

Dá uma lida, e se achar interessante, manda ver, senão, pode deletar sem dó

Abraços e segue o link abaixo ![...]

Post 5: Playstation 3 com precinho camarada - R\$7980,00, publicado no MeioBit em 30/11/2006

snowman $\bullet 6$ anos atrás

Olá! Acabei de iniciar um blog novo especialmente pra falar desses absurdos. [...]

Bom, segue o endereço para meu blog:[...]Espero que gostem.

Nas observações realizadas, percebemos que as tentativas de divulgação de blogs e perfis em sites de redes sociais são menores no MeioBit do que nos dois outros blogs. Isso ocorre pelo fato de que o sistema de gerenciamento da seção de comentários no MeioBit permite aos(às) comentaristas que criem suas próprias assinaturas para as mensagens postadas. Portanto, muitos(as) aproveitam a oportunidade para divulgarem suas páginas ao final do comentário feito.

Nessa categoria, o(a) comentarista tenta aproveitar-se da visibilidade do circuito-Cardoso para conquistar visitantes para suas páginas pessoais. Porém, como realizar essa divulgação sem irritar o blogueiro? Notamos algumas táticas, nas quais o(a) comentarista realiza um comentário, expõe suas considerações e, nas entrelinhas, aproveita para fazer a ligação entre o post comentado e uma de suas publicações. Nesse momento, o(a) comentarista insere o link para seu blog. Isso abre margem para dois pontos: o(a) comentarista estaria alinhado(a) às ideias de Cardoso ou ele(a) pensou em um post complementar ao post de Cardoso para fazer a divulgação de seu blog

As abordagens demonstram o receio que blogueiros(as) iniciantes têm em relação a Cardoso. Observamos pedidos de "desculpa" ou "licença", como se estivessem pedindo autorização ao blogueiro para usar o espaço de seus blogs para fazer divulgação. Nesses casos, os (as) comentaristas se colocam em uma posição humilde, chegando a imaginar o quão a vida de Cardoso deve ser atribulada em razão de sua popularidade.

No caso do MeioBit, foi elaborada uma ferramenta que permite a comentaristas colocar seus links para perfis de sites de redes sociais e para blogs como se fossem a assinuatura para os seus comentários. Por essa razão, as tentativas diretas de divulgação são menores. 
O uso das seções de comentários do Blog do Cardoso, do Contraditorium e do MeioBit, para a divulgação de outros blogs e de páginas pessoais em sites de redes sociais, pressupõe que o(a) blogueiro(a) em questão deseja conquistar o público que visita os blogs de Cardoso. Logo, para se chegar a essas audiências, se faz pertinente seguir as diretrizes impostas pelo blogueiro aos ambientes digitais em que atua. Dessa forma, em vez de simplesmente escrever "visite o meu blog", o(a) comentarista expressa as suas considerações para o post em questão e, como forma de complementar tanto as ideias expostas por ele(a) quanto por Cardoso, indica o link para o seu próprio blog. É uma forma de colocar-se como alguém que tem acesso às mesmas informações que Cardoso e que, sob uma ótica complementar, escreveu sobre o assunto.

Além disso, os(as) comentaristas que divulgam links para suas páginas pessoais reconhecem Cardoso como uma microcelebridade influente e popular. Nesse sentido, esses indivíduos seguem as regras existentes no circuito-Cardoso e adotam uma posição de "aprendizes" para fazer essa forma de divulgação.

\section{- $\quad$ Assim é Cardoso para os(as) comentaristas}

Conforme vimos anteriormente, Cardoso definiu a sua persona digital na seção "Quem sou eu" de seu blog, onde estabelece de "onde fala" com base em suas experiências pessoais e profissionais. Paralelamente, seus(suas) comentaristas complementam essa descrição e ajudam a reforçar as características da persona digital do blogueiro. O ponto de vista dessas pessoas contribui para a caracterização de performances e de interações de Cardoso. Ou seja, seus(suas) comentaristas dão um contorno palpável à persona digital do blogueiro.

Post 1: Ou dá ou desce, bispo Macedo!, publicado no Blog do Cardoso em 01/12/2005 - 1.181 comentários

Zé_das_Couves. 307 weeks ago

Cardoso, "u qui mas mi inspanta niço tudu é comu voçe concegui intendê o portuguêis dessis porta"

Obrigado por tantos risos e reflexões em meio às pitadas de mal humor.

Grande abraço, o seu blog é parada obrigatória para mim.

Post 2: Exclusivo: As fotos do acidente do vôo 1907 da Gol de dentro do avião, publicado no Blog do Cardoso em 26/10/2006

Vinicius. 324 weeks ago

Parabéns Cardoso, como sempre chamando os leitores do Carloscardoso.com de Idiota.[...] lucas. 324 weeks ago

Você é anti-ético, perdeu toda credibilidade que seus blogs tinham publicando estes posts. 
Post 2: Apagão da Internet: Orkut vai sair do ar!, publicado no Blog do Cardoso em 02/08/2007

Butch 285 weeks ago

Cardoso você não presta... rss

Daqui à pouco vai ocorrer uma série de protestos de "miguxos" e emos em todo o Brasil...

e teu blog vai ter uma centena de comentários dos mesmos protestando.

Post 3: Atendendo a pedidos - mais ou menos, publicado no Contraditorium em 03/12/2008

Roberto Almeida. 210 semanas atrás

Hahahahaha....

Carlos Cardoso...

Você é detestavelmente, malevolamente, anarquicamente, deliciosamente, sordidamente mau...

E quer saber? A gente adora isso!!!

Hahahahaha...[...]

Gilson Ricardo 209 semanas atrás

Rapaz, sei que esse comentário tem pouco haver com post acima mas vamos lá.

Vejo tanto o seu Avatar como Dr.House, que na última foto custei a acreditar que era você mesmo, hahaha. Tinha que fazer uma montagem do Dr.House encostado no 4x4, aí ia ser massa :)

Abraços !

Post 4: Haiti - terra amaldiçoada por Deus, publicado no Contraditorium em 13/01/2010

Diego 152 semanas atrás

[...]Não é porque o Cardoso fez uma piada, que na minha opinião foi boa, que ele não sinta nada pelo sofrimento daquele povo - embora eu ache que ele não sinta mesmo heheh.

Se fosse alguém de lá fazendo a mesma piada diriam que é um gênio mas como foi alguém que não esta lá para compartilhar a dor e o sofrimento com os Haitianos é chamado de insensível.

Post 5: Brasil e Moçambique vão cooperar no desenvolvimento científico nas telecomunicações, publicado no MeioBit em 26/11/2008

QBBFTWGMO $\bullet 4$ anos atrás

Seria este o post mais comentado da história do MB?

GusTales -> QBBFTWGMO • 4 anos atrás

E vc tem alguma duvida?

Eu pelo menos não achei nenhum post maior que esse.

Pergunte ao "todo poderoso" Cardoso. Ele vai te falar uma resposta certa.[...]

Post 6: Linux atinge marca histórica de 1\% do Mercado, publicado no MeioBit em $02 / 05 / 2009$

wallysou $\bullet 4$ anos atrás

pro post do Cardoso ser mais lido do q isso, só se ele tivesse colocado como título (que seria bem dele mesmo):

"Linux atinge a marca HISTÉRICA de $1 \%$ do mercado"

ideia licenciada sob CC.[...]

A opinião do público pode legitimar ou derrubar uma performance, especialmente em ambientes digitais. Os(as) comentaristas dos blogs de Cardoso parecem interferir, inclusive, na atuação do blogueiro que, por sua vez, volta suas 
performances e interações para obter atenção de seu público. Na jornada de se tornar um "blogueiro profissional", observamos a importância de garantir credibilidade à persona digital assumida nesses ambientes. Nesse sentido, o que é publicado, as temáticas de interesse e, principalmente, os posicionamentos e opiniões determinam a legitimidade para ocupar essa posição de destaque para Cardoso.

Para seus(suas) comentaristas, Cardoso é alguém com opiniões marcantes e polêmicas cujas interpretações são usualmente contestadas. Seus(suas) críticos(as) veem o blogueiro como alguém cujo objetivo é o de incitar discussões sem sentido, ao colocar em lados opostos grupos que, normalmente, nunca chegarão a um consenso. Podemos perceber isso quando Cardoso publica posts sobre temas religiosos, sendo que a maioria de seus(suas) fãs, assim como o blogueiro, não têm religião definida. Naturalmente, isso gera longos debates em que cada um(a) defende seu ponto de vista até a exaustão.

Por outro lado, o comportamento de Cardoso assume uma postura de alguém que controla com autoritarismo as participações de seus(suas) visitantes. Ou seja, embora seja estimulado o debate, as pessoas que costumam contrariar o blogueiro são recriminadas tanto pelo próprio Cardoso quanto por sua "corte". Por essa razão, Cardoso é visto como alguém que prefere não ser contrariado e não mede esforços para expressar e reforçar suas opiniões e criticar o(a) comentarista em questão.

Da parte de seus (suas) seguidores(as), Cardoso é visto como alguém que possui um lado sarcástico bem apurado. Além disso, para sua corte de leitores(as), o blogueiro é alguém com bastante conhecimento e que sabe como compartilhar saberes adquiridos ao longo de sua vida pessoal e profissional, especialmente quando faz conexões, referências, piadas e sarcasmos. A reação que causa naqueles(as) que discordam de seus posts é vista por esse grupo com desprezo, como uma característica desqualificadorada da inteligência dessas pessoas.

O uso de técnicas para atrair visitantes por meio de sites de busca é um dos tópicos sempre criticados pelos(as) leitores(as) que discordam da postura de Cardoso. Por ser algo assumido publicamente pelo blogueiro, isso se torna um aspecto que prejudicaria a imagem dele na blogosfera, tendo em vista que o uso de táticas para atrair visitantes é algo considerado ruim por parte de blogueiros(as). 
Além disso, o fato de Cardoso se aproveitar de notícias de grande repercussão, de fatos polêmicos e bastante comentados é visto como oportunismo, gerando discussões nas quais os dois lados (favoráveis e contrários) debatem se isso poderia ser usado para esses fins. Em alguns momentos, os(as) próprios(as) fãs questionam essa postura justamente porque atrai muitas pessoas e, por terem opiniões opostas à corte de Cardoso, seus comentários acabam "poluindo" os blogs.

Em alguns momentos, podemos notar que Cardoso é visto como uma pessoa direta, que fala o que pensa, sem medo de ser parcial. Esse é um ponto comum tanto para sua corte quanto para os(as) que tentam derrubar seus argumentos. O modo com que Cardoso aborda determinados assuntos, especialmente os de cunho religioso, é criticado pelos(as) comentaristas que seguem a religião criticada. Ainda, da parte dos(as) que seguem as opiniões do blogueiro, o posicionamento de Cardoso é inquestionável porque ele é o dono/administrador desses blogs. Apesar de imprimir a inquestionabilidade de seus posts, Cardoso se dispõe a considerar opiniões contrárias, desde que estas sejam bem argumentadas, segundo o ponto de vista do blogueiro.

Cardoso é um blogueiro que deseja ter total controle dos ambientes digitais em que realiza suas performances, bem como das ideias contidas em suas publicações. Seu pensamento, suas opiniões, seu comportamento e as referências e gostos pessoais precisam ser relembrados a todo instante e funcionam, ainda, como mecanismo para "filtrar" as suas audiências.

Seus interesses parecem estar sempre ligados a experimentos nos quais pode perceber a real atenção recebida. Além disso, Cardoso incita demonstrações públicas de seus(suas) visitantes nas seções de comentários, uma vez que um blog popular é um blog que conta com vários comentários.

A sua performance peculiar tem lhe rendido inúmeras críticas. Quase sempre, o blogueiro deixa de ponderar a respeito das opiniões contrárias e admite, publicamente, que dificilmente mudará o seu posicionamento.

O controle que exerce sobre os seus blogs parece compor a sua persona digital. Notamos, por parte de Cardoso, o cuidado em preservar uma coerência quanto às características assumidas em sua seção "Quem sou eu", assim como em seus blogs. Isso lhe rendeu uma fama de "arrogante", "antiético" e "sensacionalisla" na Web. Entretando, mesmo com toda essa fama negativa, 
Cardoso possui um dos circuitos-blogue mais populares dentro de temáticas ligadas à cultura geek.

O blogueiro conseguiu sua popularidade com base em seus(suas) seguidores(as) - a corte de Cardoso - e, ainda, contando com aqueles(as) que criticam as performances realizadas pelo blogueiro.

$* * * * * * * *$

Carlos Cardoso considera-se alguém capacitado para atuar em ambientes digitais, tanto pelo conhecimento nas áreas de informática e de tecnologia da informação, quanto por sua experiência em ambientes digitais que data dos primórdios da Internet, como explicita na seção "Quem Sou Eu" do Blog do Cardoso. O blogueiro tem a preocupação de manter características definidoras de sua persona digital em todas as performances, buscando fazer referências constantes a outros posts em uma tentativa de evitar contradições de seus posicionamentos e opiniões.

Nos momentos nos quais precisa rever conceitos, o blogueiro apresenta argumentos os quais estão alinhados à sua postura, embora esta seja, em muitos casos, considerada controversa por seus(suas) comentaristas. Estes, por sua vez, veem Cardoso como uma figura de destaque que, por essa razão, usa a sua fama em ambientes digitais para difundir suas ideias. Nesse sentido, dentre esses(as) comentaristas, é bastante comum encontrar aqueles(as) que discordam da postura de Cardoso e expressam seu repúdio na forma de comentários ou, até mesmo, de posts em suas páginas pessoais.

Quando assumem de onde falam, os(as) comentaristas reconhecem a existência de uma "voz" e, por isso, precisam confirmá-la ou refutá-la. Por sua vez, essas ações legitimam a condição de microcelebridade, bem como a persona digital do blogueiro. Em contrapartida, elogios, críticas e sugestões reforçam o complexo sistema ao qual se submetem microcelebridades, pelo fato de que, ao exporem suas opiniões, estão sujeitos a manifestações favoráveis, contrárias ou complementares.

A importância de descrever "quem é Cardoso" por meio do circuito-Cardoso pretendeu identificar se a performance do blogueiro, sob a perspectiva dos comentários de suas audiências, é reconhecida como um papel de destaque. Nessa seção, verificamos a defesa e a habilitação de um circuito-blogue, no entendimento de que, para ser legitimável, é preciso que ocorra, simultaneamente, 
o reconhecimento do público e performances cabíveis a uma persona digital pública.

Quanto ao reconhecimento, existe uma dualidade: a defesa e a crítica das ações de Cardoso. Em conjunto, a oposição dessas forças dá existência à persona digital do blogueiro. Uma vez que alguém faça alguma crítica, a pronta defesa reforça a noção do circuito-Cardoso como um conjunto de pessoas e mecanismos que dão legitimidade à "fala" do blogueiro. Os posts e o estilo do blogueiro retratado neles, assim como a contrapartida dos comentários, definem quem é Cardoso nos ambientes digitais: polêmico, parcial e com uma "fala" que é capaz de atrair iniciados(as) e "paraquedistas".

Segundo suas suas audiências, o blogueiro assume dois lados, o inteligente e o antiético, que, ao final, funcionam como uma espécie de "cola" para legitimar a popularidade de sua persona digital. Quando o próprio Cardoso se apresenta, existe o interesse em dar credibilidade a sua "fala", por meio de experiências de vida e do conhecimento acumulado. Ao conjugar essas diferentes visões, percebemos que Cardoso é alguém que tem reunido características identificadoras, tais como: alguém que que deseja ser um "blogueiro profissional"; incentivador de debates acalorados entre comentaristas; uma pessoa que tem opiniões parciais; se autodenomina geek; alguém que assume fazer uso de técnicas para atrair visitantes e, assim, gerar renda para seus blogs; trata seus(suas) comentaristas de acordo com o ponto de vista que defendem; faz uso de sarcasmos, ironias e referências para "selecionar" e conquistar seu público. 


\title{
4.2. A Corte de Cardoso: valores e hierarquias
}

\author{
- $\quad$ O bom uso do Português
}

O uso do português nas seções de comentários do Blog do Cardoso, do Contraditorium, e do MeioBit pode determinar o sucesso ou o fracasso de uma participação nesses ambientes. Isso acontece em razão do estilo da escrita, da escolha das palavras e das concordâncias, que funcionam como parâmetros para medir o quão próximo da "corte de Cardoso" o(a) comentarista estaria. Ou seja, essa avaliação considera que, para fazer parte do grupo, se faz necessário o indivíduo saber escrever corretamente, consiguir se expressar e, principalmente, fazer um bom uso do Português.

Qualquer erro, ainda que seja de digitação, pode ser condenado, a menos que o(a) comentarista em questão já tenha algum prestígio no circuito-Cardoso. Do contrário, uma enxurrada de comentários críticos aparece e o(a) comentarista em questão corre o risco de ser segregado(a) e receber algum apelido pejorativo.

Post 1: Ou dá ou desce, Bispo Macedo, publicado no Blog do Cardoso em 01/12/2005 - 1.181 comentários

ruth. 310 weeks ago

O que estar acontecendo com esses comentario maldosos, e a falta de temor a Deus.Esse pastor, se um dia ele foi pastor mesmo e teve um pouco de conhesimento da palavra de Deus creiu que nao estar dormindo em paz,ele fez igualsinho o judas com poucas moedas judas traiu jesus.Olhe ainda ha tempo de se arepender de seus pecados aseite jesus deverdade na sua vida. Aposto que o bispo Edir Macedo nao estar nenhem um pouco preocupado ,pq tudo isso nao passa de calunias a vida dele pertence a Deuse quem tenhem a vida entregue a Deus nao teme. Tudo que vi nao mim abalou, por que sou de DEus. Fui obreira da iurd muinto tempo, ohje estou afstada da obra pq mudei de pais, mas o que sou ohje devo au conhecimento da palavra de Deus ,que foi e e usada atraves dos pastores deta igeja .Que Deus abencoe todos voces que tentam denegrir a iurd.ester

Cardoso. 310 weeks ago

"conhesimento". Fala sério, Ester, todo mundo na IURD é analfabeto mesmo? Impressionante como vocês são burros, não sabem escrever e não conseguem organizar suas idéias. Volte pra escola, vai.

Post 2: Imagens exclusivas: terremoto no Haiti, publicado no Blog do Cardoso em $12 / 01 / 2010$

Dr. Eduardo Silva 151 weeks ago

bom dia a todos amigos eu estou aqui no haiti ja a 4 dias e acredite e um senario horrivel todos tem razão aqui era ruim antes e agora so esta pior, e quando dizem que todos os encomodados poderiam estar fazendo algo ate mesmo abrigando alguem em sua casa [...] muita gente esta vendo a net e muitos blogs assim como esse e ninguem intende como o povo brasileiro um povo feliz alegre que acolhe a todos escreve coisas de algo que não entende [...] para aquele que esta com peninha do haiti sei que nao pode vim para ca e nem acolher ninguem em sua casa 
Dr. Edson! Essa foi boa!!!

... a 4 dias, cenario horrivel, encomodados, intende...

Acaso compraste o diploma de um dos amiguinhos da praca da $\mathrm{Se}$

PS. Meu teclado esta com defeito, por isso, nao coloquei acentos. mas nao poderia perder essa. Hehehe...

Post 3: Quem quer ver as fotos dos corpos do acidente da gol?, publicado no Contraditorium em 06/10/2006

Gabriel· 317 semanas atrás

[...]lamentavelmente que todos (ser Humano) gostamos de ver sangue (desgraças de proximos) mas acreditem e lamentavelmente a perca de alguem cujo a vida esta na sua mao, e mais ainda quando temos um acidente em nossa frente e nao salvamos a vitima no qual podemos fazer sempre algum, a coisa mas nao fazemos, quer disser fazemos sim. [...] acreditem isso é a pior coisa que podemos sentir as piores das piores percas, e posso garantir que em vez de ficarmos olhando e saber que aquela vitima que iria morrer insendiada na batida de carro, ou aquela que foi vitima de um atropelamento..esta viva e com sua familia em casa porque um de nos que estava na PLATEIA simplismente correu e apagou o fogo com um instintor ou que chamou ajuda e acompanhou o resgate do atropelado.. entao meus amigos pensem bem antes de falar uma piada pense que poderia ter alguem que vc ame muito. ai te garanto que vc nao iria nem siquer fazer um comentario por mais simples que ele seja.[...]

Cardoso 317 semanas atrás

Primeiro, você não é médico. Nenhum médico escreve "siquer" e "simplismente". SEGUNDO você um idiota, achando que está enganando alguém, postando uma mensagem de apoio com nome falso. Veja o cabeçalho do PRIMEIRO comentário:

New comment on your post \#445 "Quem quer ver as fotos dos corpos do acidente da Gol?"

Author : Gabriel (IP: 200.175.174.141 , 200.175.174.141)

E-mail : [...]@hotmail.com

Agora o do segundo:

New comment on your post \#445 "Quem quer ver as fotos dos corpos do acidente da Gol?"

Author : Eu (IP: 200.175.174.141, 200.175.174.141)

E-mail : [...]@hotmail.com

URI :

Portando, seu mentiroso semi-analfabeto, vá ciscar em outro terreiro, ok?

Post 4: Controle de zoonoses não protege o seu bichinho - eu adorei, publicado no Contraditorium em 13/01/2009

Tomiko-chan. 204 semanas atrás

Não seria controle de zoonoses? [...]

Post 5: Brasil e Moçambique vão cooperar no desenvolvimento científico, publicado no MeioBit em 26/11/2008

GusTales -> pointer• 4 anos atrás

Tah doido?

Claro que afetaria.

O BRASIL É O SELEIRO DO MUNDO!![...]

Pryderi $->$ GusTales $\bullet 4$ anos atrás

[...]Somos o celeiro (com C, por favor) do mundo. bemn, eu só posso dizer...

DANEM-SE![...]

Post 6: TechEd 2008 - Linux Marcando Presença, publicado no MeioBit em 15/10/2008 - 467 comentários

\section{Pintogrande $\bullet 4$ anos atrás}

Ummmmm... Faz pouco que vejo este blog, mas realmente parece que vcs tem uma certa implicancia com o linux...[...] de ahi para aca a historia sempre foi a mesma a : Entre 6 meses o mais o computador comeca a bichar e tem q formatear e instalar tudo de novo ... para isso tem um amigo que eu chamo ele para almorzar e ele de pasada istalava tudo de novo ...pronto, mais ja tava cansado do windows e seus problemas e ele me dice q esta 
usando um tal do Ubuntu e me sugeriu para instalar el junto con meu windows... [...] Otro dia meu amigo tecnico me preguntou se eu queria actualizar o ubuntu para a versao nova mais para que ? como dizem por ahi time que ta ganando nao se mexe...

Derepente a diferenca seria para alguem que joga, parece que no linux tem poco jogo , mais para iso estao as consolas, eu comprei o Wii e tou adorando .muito melhor que o computador para jogar... [...]

dogmatch $->$ Pintogrande $\bullet 4$ anos atrás

Você está pouco tempo aqui, então perceba que se deve escrever direito com exceções quanto a ironia, sarcasmo e erro de digitação.

Post 6: Algo misterioso vai acontecer, publicado no MeioBit em 28/04/2010 - 121 comentários

edinelton_pi $\cdot 3$ anos atrás

Porra, Lançamento do Windows Live Mensseger!!! Isso num vai mudar em nada o mundo.[...]

LucasTiesto $->$ edinelton_pi $\bullet 3$ anos atrás

@edinelton_pi,

[miguxês]

Como que naum xeu heregi?

Vai xer mtu mlhor pa eu mandar scraps pus meux miguxux do Orkuti i du MSN ao msm tempu...

[/miguxês]

Eh, naum vai mudar o mundo msm...

O bom uso do português é considerado uma forma de se expressar bem por meio da escrita. Por ser uma participação na qual, em teoria, ter-se-ia tempo de revisar, os comentários precisam demonstrar um nível de conhecimento objetivo que, por sua vez, dê credibilidade ao que está escrito. A menos que o nível de conhecimento demonstrado no comentário seja considerado relevante pelos(as) demais, um simples erro de português gera uma decepção por parte daqueles(as) que frequentam o ambiente, além de poder marcar negativamente o(a) comentarista.

Usualmente, aqueles(as) que cometem erros de português fazem parte do grupo dos(as) segregados(as) da corte de Cardoso. São pessoas que acabaram de chegar, discordam dos posicionamentos levantados, não têm familiaridade com o assunto, são conduzidas aos posts por meio de mecanismos de busca. Entretanto, notamos que mesmo aqueles(as) pertencentes à "corte de Cardoso" - ou que desejam fazer parte - podem cometer erros. Nesse caso, os erros ora são evidenciados por outros(as) comentaristas ora são corrigidos pelo(a) próprio(a) comentarista.

No circuito-Cardoso a inteligência de um(a) comentarista é medida pela capacidade de interpretar, dentro dos preceitos da "corte de Cardoso", a proposta sugerida pelo blogueiro. Por esse motivo, o bom uso da língua portuguesa, 
inclusive de palavras em outros idiomas e a interpretação adequada das referências expostas nos posts seriam elementos de concordância com as ideias abordadas por Cardoso.

No âmbito do circuito-Cardoso, os(as) inteligentes são aqueles(as) que conseguem argumentar ideias, expondo seus pontos de vista, sem que, para isso, sejam totalmente contrários às opiniões do blogueiro e de seu séquito de seguidores(as). Para alcançar esse grau, o(a) comentarista deverá adotar uma postura permeada pelo bom uso da língua portuguesa, como forma de expressão e de inteligibilidade.

Nos exemplos, notamos sátiras feitas pela corte de Cardoso aos grupos segregados e, segundo eles(as), desprovido de conhecimento acerca da língua portuguesa. Porém, percebemos que, em alguns casos, especialmente quando envolve o próprio Cardoso ("portando", em vez de portanto) ou no caso da correção sugerida para a palavra "zoonoses", as críticas não acontecem. Devido à postura de Cardoso, e temendo represálias e sofrer com a segregação, os(as) comentaristas evitam fazer colocações solicitando a correção de erros de postuguês quando o próprio blogueiro comete.

\section{- $\quad$ Criando Rótulos para Comentaristas}

As estratégias adotadas por Cardoso para tornar seus blogs populares acaba por atrair um público bastante diversificado. Muitos(as) desses visitantes são segregados(as) por discordarem das performances de Cardoso. Nesse ponto, notamos um vocabulário que denomina o tipo de participante para o Blog do Cardoso, para o Contraditorium e para o MeioBit. As alcunhas, usualmente, referem-se àqueles(as) que estão fora da "corte de Cardoso", especialmente por discordarem das opiniões do blogueiro. O próprio Cardoso, inclusive, colabora para a disseminação dessas denominações e, ainda, tenta justificar as razões pelas quais se refere a esse grupo.

Post 1: Ou dá ou desce, Bispo Macedo, publicado no Blog do Cardoso em 01/12/2005

ROBERTO MARTINS L. 366 weeks ago

ISTO QUE ESTA NESTE SITE É INSPIRAÇÃO DIABOLICA ,NÃO ACREDITEM NESTAS ACUSAÇÕES FALSAS

POIS A GLOBO GOSTARIA DE VER A UNIVERSAL CAIDA, SENDO QUE ELA FOI LEVANTADA PELO ESPIRITO SANTO 
Cardoso 366 weeks ago

Falso aonde, crente burro? E se a Globo gostaria de ver a Universal Caída, ótimo pra ela, eu também gostaria.

douglas. 231 weeks ago

otario é vc cardoso que é recalcado pq nao conseguiu ser nenhum por cento daquilo q o bispo é ele influencia milhoes de vidas e vc com seu discurso aposto q nao convence nem a sua mae idiota

Cardoso. 231 weeks ago

Uau, RESPEITAR PAI E MÃE NADA, não é, cristãozinho? Pra me xingar vale violar um dos 10 mandamentos?

Post 2: Exclusivo: As fotos do acidente do vôo 1907 da Gol de dentro do avião, publicado no Blog do Cardoso em 26/10/2006

bruno. 319 weeks ago

Sabe que isso é maldade com os paraquedistas do Google né?! :)

Duas coisas, as pessoas adoram esse esquema de que algo foi encontrado no meio dos destroços, ficam pilhadas e param de ler na hora para disseminar a coisa toda por email... E esse link no final do texto, as pessoas nem vão chegar até ele...

Post 3: Perdendo a fé na humanidade, publicado no Contraditorium em 07/08/2007

Ontem foi MUITO legal o encontro de blogueiros. O mais fantástico é que tinha muito mais Mauro Ciccone. 279 semanas atrás

Hahahahahahahaah

PAI CARDOSO!

hahahaha ganhei o dia!!!

Pérolas@Salsinhas

Cardoso, manda um e-mail com supostas previsões feitas "sob encomenda" pra salsinha em questão.

Seria cômico um post desses.

Post 4: Por favor, não matem os meus heróis, publicado no Contraditorium em $25 / 01 / 2011$

leonardolimaq. 98 semanas atrás

Agora eu li o texto dela e vi que o que ela fez foi comparar os personagens como são retratados hoje, do que como eles eram retratados antes. Ela não falou mal de quadrinhos, ela falou do que se faz hoje com determinados personagens. $E$ eu concordo muito com ela que muitos personagens se tornaram grandes babacas - nos filmes. $O$ homem aranha 3 por exemplo: ele só ferra o eddie. O Eddie tem todos os motivos do mundo pra querer mal o Peter. O Tony Stark é um babaca, o Bruce Wayne é um playboy babaca. E a Rachel merece soco. Beija um, beija outro, que mulher é essa?

Bernardo Teck. 97 semanas atrás

Não alimentar os trolls Não alimentar os trolls

Post 5: Brasil e Moçambique vão cooperar no desenvolvimento científico, publicado no MeioBit em 26/11/2008

cnnmocambique $\bullet 4$ anos atrás

sempre pensei que alguem com este nome <carlos cardoso="" $>$ fosse descendente de Português, mas parece descendente de Russo (risos) tamanha é a sua ignorancia q ultrapassa o seu nivel de conhecimento[...].

Abra a sua mentalidade, vc consegue a nao ser que for mesmo descendente de portugues. Nao se preocupem com seus problemas de matematica, os meus sao ainda maiores. Dr Albert Einstein.[...]

Carlos Cardoso $\rightarrow$ cnnmocambique $\bullet 4$ anos atrás

Angolano recalcado querendo trazer pra cá seu ódio contra portugueses? TROLL.[...] 
Post 6: Linux atinge a marca histórica de $1 \%$ do mercado, publicado no MeioBit em 02/05/2009

Indefinido $\bullet 4$ anos atrás

voce esqueçeu de completar tard feliz porque eu aproveito reamente tudo da internet :) (agora voce so fica nessa vidinha de chamar os outros de tard e nao aproveita nada)

LINUX=DOR DE CABEÇA COM AS NOVAS TECNOLOGIAS QUE VIRAO E NAO SERAO SUPORTADAS=ISOLAMENTO=TUDO DIFICIL=NINGUEM APROVEITA NADA(quero ver os pinguins no clould computer onde nao vai dar pra entrar no nucleo pra editar o kernel, vao ter que ficar usando so o que eles liberarem)

SEVEN=NUMERO PERFEITO=SISTEMA OPERACIONAL PERFEITO(aqui realmente voce aproveita)

gaviao_molhado $\rightarrow$ Indefinido $\bullet 4$ anos atrás

[...]"Kernel nas nuvens" - Esse cara além de Troll e Tard ainda é Salsa, acho que temos um novo recorde aqui.[...]

Juliano-Buettner $\rightarrow$ Indefinido $\bullet 4$ anos atrás

É que não tenho nada pra fazer, anão ser twittar ou ler blogs e este post está cheio de tards. [...]

Juliano-Buettner $\rightarrow$ Moca10 $\bullet 4$ anos atrás

[...]Falta aí um bot *tard. Um bot que fale coisas sem sentido mas que fale bem (ou mal, dependendo da palavra chave) do assunto tratado.[...]

Pryderi $\rightarrow$ P_Mares $\bullet 4$ anos atrás

Tard+Salsa+Troll

Pacote completo.[...]

Juliano-Buettner $\rightarrow$ P_Mares $\bullet 4$ anos atrás

Típico Casas Bahia user.[...]

tesla $\bullet 4$ anos atrás

[...] Sim existe diversas distro, muitas problemáticas, mas tem distro boas também, mas sempre é mais fácil criticar e ver o lado ruim da história.[...]

Juliano-Buettner $\rightarrow$ tesla $\bullet 4$ anos atrás

*tard detected.

Nós malhamos MUITO o Vista e o Millenium (e o Satux também).[...]

Pryderi $\rightarrow$ Juliano-Buettner• 4 anos atrás

Liga não. *tards não costumam ler postagens integralmente.[...]

Lúcio $\rightarrow$ tesla• 4 anos atrás

Senhoras e senhores, temos um candidato à insígnia de *Tard

Sem falar que a referida frase do meu comentário foi partido ao meio, quebrando o seu significado[...]

Nessa categoria, percebemos que os(as) comentaristas de Cardoso e o próprio blogueiro costumam "rotular" aqueles(as) que discordam da opinião do grupo. Nessa observação, conseguimos identificar alguns apelidos que se repetem com certa frequência nas seções de comentários do Blog do Cardoso, do Contraditorium e o MeioBit.

No Blog do Cardoso, no Contraditorium e no MeioBit encontramos as(os) salsinhas, salsinhas de cristo, paraquedistas, tards, freetards, trolls, fanboys/fangirls. Em todos os casos, a referência é pejorativa e indica o grau de "inferioridade" que o indivíduo tem para o grupo dos(as) seguidores(as) de Cardoso. Sob a perspectiva da "corte de Cardoso" e de seus(suas) admiradores(as), essas pessoas merecem ser segregadas, pois não foram capazes 
de seguir as regras existentes no circuito-Cardoso. Dentre as quais, saber como se comportar em uma discussão/comentário; fazer bom uso do português; saber apresentar argumentos embasados acerca de seus pontos de vista.

Cada comentarista recebe uma qualificação diferente pelo tipo de participação que faz. Nesse contexto, aqueles(as) que reclamam de tudo são conhecidos(as) como trolls. Aqueles(as) que não leem todo o texto do post e apresentam comentários repetitivos ou defendendo a sua posição, independente do assunto abordado, são chamados de salsinhas/salsinhas de cristo. Os(as) comentaristas que chegam aos blogs de Cardoso por meio de sites de busca são os(as) paraquedistas. Aqueles(as) que não aceitam de qualquer forma um ponto de vista contrário aos seus são conhecidos como tards/freetards.

A categorização de frequentadores(as) das seções de comentários dos blogs de Cardoso separa quem estaria dentro do grupo daqueles(as) que não pertencem àqueles ambientes. Ou seja, aqueles(as) que estariam de fora são, na maioria dos casos, pessoas que discordam do modo que Cardoso aborda determinados assuntos e, ainda, dos critérios usados por ele para atrair visitantes.

Essa forma de denominar os visitantes parte tanto do próprio Cardoso como de seu séquito de seguidores(as). Ao designar alguém como tard, como salsinha, como troll ou como paraquedista, Cardoso e sua "corte" colocam-se como detentores(as) de um nível de inteligência apurado para ironias, sarcasmos e para o engajamento em debates. Nesse sentido, qualquer um(a) que não consiga interpretar de maneira semelhante, são considerados menores e se tornam motivos de piada dentro do grupo. Categorizar alguém como um "segregado" parece também ser uma forma de incluir-se no grupo da corte de Cardoso e, de certa forma, busca ser aceito por não compartilhar daquela opinião.

$\mathrm{O}(\mathrm{A})$ comentarista habitual segue o pensamento de Cardoso de forma sutil. Ou seja, a inferência ao post é feita a partir de uma colocação complementar, evitando manifestações diretas do tipo "Concordo contigo" ou "Você está certo". Essa sutileza parece funcionar como uma credencial para que a parte periférica da corte se inspire em uma pessoa que faz a intermediação entre o blogueiro microcelebridade e o grande público da corte. O comportamento desse habitual tende a assumir as atitudes de Cardoso - como os momentos de grosseria - em seus comentários, fazendo uma defesa a partir de um ponto de vista que, como foi dito, faria uma espécie de mediação. 
Como o MeioBit é um blog dedicado a assuntos científicos e tecnológicos, os(as) "segregados(as)" recebem a denominação tard, que é uma redução palavra em língua inglesa retard. São pessoas que defendem a todo custo o seu sistema operacional preferido, ignorando os defeitos e tentando elaborar diversas qualidades. São semelhantes aos fanboys, que consomem todo tipo de produto ligado a uma determinada marca, como a Apple. Daí, por essa razão, dizem que a marca em questão é melhor sem apresentar nenhum argumento consistente, segundo a "corte de Cardoso".

Separar os(as) frequentadores(as) dos blogs de Cardoso revela-se uma forma de desenhar uma hierarquia dentro dos ambientes digitais dos quais o blogueiro participa. Essa hierarquia tem na sua figura o papel principal e, gradualmente, se expande para seus(suas) seguidores(as). Os(as) mais atuantes recebem uma atenção especial, não só por sua participação, mas por concordar com as ideias e com as atitudes de Cardoso e, ainda, complementá-lo sem ofendê-lo. Concordar com o blogueiro é um mecanismo de entrada, como se fosse um elogio sutil ao tipo de abordagem feita por Cardoso. À medida que essa participação é mais ativa, o(a) comentarista começa a obter destaque dentro do circuito-Cardoso, podendo se tornar microcelebridade ou não.

Entretanto, essa participação nem sempre é acompanhada diretamente por Cardoso. Ou seja, mesmo participando diversas vezes, concordando com suas ideias e propiciando os almejados debates "com conteúdos e argumentações", o blogueiro quase sempre não responde aos comentários. Por outro lado, Cardoso faz questão de manifestar-se nos momentos que precisa impor suas ideias e, especialmente, quando precisa segregar algum(a) comentarista.

\section{- Os Códigos dos(as) Iniciados(as)}

A noção de grupo no Blog do Cardoso, no Contraditorium e no MeioBit parece ser consumada por meio de linguagens e códigos percebidos somente pelos(as) iniciados(as). Esses indivíduos conhecem - e admiram - o modo pelo qual Cardoso faz suas referências, piadas e sarcasmos, tendo em vista que esse estilo peculiar parece fazer parte de suas vidas. A cultura geek costuma alimentar muitas ideias contidas nos posts de Cardoso, assim como pitadas de sarcasmo complementam a abordagem feita pelo blogueiro. Além disso, os(as) 
comentaristas iniciados(as) possuem liberdade para postarem, na forma de comentários, suas próprias piadas, sarcasmos, ironias e referências, antecipando o que o próprio Cardoso pensaria em complemento ao comentário realizado.

Apesar das táticas usadas por Cardoso, para atrair visitantes, parece-nos ser a esse público - dos(as) iniciados(as) - que o blogueiro se dirige em seus posts.

Post 1: Exclusivo: As fotos do acidente do vôo 1907 da Gol de dentro do avião, publicado no Blog do Cardoso em 26/10/2006 - 1.106 comentários

Paulo G Muller. 277 weeks ago

Tu não tens IESUS no coração.

Beba um Fraga da Moira que as portas lhe serão abertas.

Quando ELE disse:

Vinde a mim as criançinhas...

Ele quis dizer:

Crianças, crianças burras, crianças que fazem crianças....

Tu perdestes a criança que havia dentro de ti.

Falando em criança...

Cadê a Padawan ? óóóóóóhhhhhhhh, por DEUS, que criança...

Post 2: $O$ que é pior: Matar 20 milhões de pessoas ou sacanear um pedaço de pão?, publicado no Blog do Cardoso em 15/01/2009 - 58 comentários

Thiago 209 weeks ago

E o Miojo representa o corpo da minha divindade de escolha, o Monstro do espaguete Voador

plz to not dessecrate my god and his noodly appendage kthksbai

Cardoso. 209 weeks ago

Ramen!

Post 3: Controle de zoonoses não protege o seu bichinho - eu adorei, publicado no Contraditorium em 13/01/2009 - 160 comentários

Andre. 204 semanas atrás

Escuta, fui só eu que percebeu que o nome da mulher é Samantha Stevens? Ela literalmente torceu o nariz pra atitude do cão. HAHAHAHAHHAHAHA[...]

Post 4: Por favor, não matem os meus heróis, publicado no Contraditorium em $25 / 01 / 2011$

Sherlock. 98 semanas atrás

Não sou conhecedor de quadrinhos mas entender seja lá o que for por um lado só e vendo apenas um pedaço de um universo bem maior e mais complexo não é nem de perto o que um pesquisador deveria fazer.

Em tempo, também não conheço Star Trek e fiquei curioso com a cena da foto...

Mário José Serran. 97 semanas atrás

$\mathrm{Na}$ foto há um diálogo maravilhoso: Spock está morrendo para salvar a nave e Kirk pergunta:

"-Porquê, Spock?"

"-Porque as necessidade de muitos superam as necessidades de poucos... ou de um."

Está no fime Star Trek II.

Espero ter esclarecido.

William. 98 semanas atrás

Maravilhoso o texto! É impressionante como escapa a muitas pessoas todos os significados simbólicos que os heróis têm, assim como os vilões que representam nosso lado negro, os 
heróis também são todos uma parte de nós, e psicólogos têm o péssimo hábito de querer meter o bedelho onde não conhecem sem ter o devido aprofundamento do assunto.

PS: Amei a referência ao Shrek.

Post 5: Blue me punto para Microsoft, publicado no MeioBit em 05/10/2007

TraceMiller 5 anos atrás

Podiam integrar o Zune Market place, um WiFi, e WoW:

Windows Media Center Car Edition, estaciona do lado de um shopping, roba um WiFizinho gratuito, para do lado de um amigo, ele te passa as musicas dele e... Ok Ok, parei!

Eu gostaria de um carro com o Blue\&Me, mas o Punto... Ele é meio estranhinho !

Anyway, enquanto não chegar a época de Matrix, está tudo muito bem![...]

lucasb4 5 anos atrás

Onde é o ctrl + alt + del?

Embreagem + Acelerador + Freio?

zaio44 $->$ lucasb4 $\bullet 5$ anos atrás

Onde é o ctrl + alt + del?

Embreagem + Acelerador + Freio?

Quá!!! Quá!!! Quá!!! Quá!!! [...]

Quase caí da cadeira aqui! :-DDDDD [...]

oyjoaosi $->$ lucasb4 $\bullet 5$ anos atrás

[...]cara eu to rindo faz uma meia hora só de imaginar como seria a cena... o cidadão pisando nos três pedais pra dar o restart no carro $=$ ) $[\ldots]$

Kobald ->lucasb4 $\bullet 5$ anos atrás

Olhe de novo as fotos rapaz!

O alt fica do lado do botão windows e o ctrl e del ficam do outro lado do volante, na outra mão :D[...]

Kobald $\bullet 5$ anos atrás

Se fosse a apple seria num Civic

Linux num chevete multicolor, igual ao que tem perto da minha casa...[...]

Aqualate $->$ Kobald $\bullet 5$ anos atrás

Ai depende da distro ; $\mathrm{D}$ Um seria num chevete, outro num Fusca, outro num Mitsubishi, outro num Omega, outro num Escort, outro num Vectra etc.. Teria aqueles em Mazda, Jaguar, Lexus... E, é claro, teriam aqueles em Porsche, Lamborghini, Ferrari e quem sabe uns até me Rolls Royce ;P [...]

Post 6: Algo misterioso vai acontecer, publicado no MeioBit em 28/04/2010 - 121 comentários

ninabjsilver $\bullet 3$ anos atrás

Huhuhuhu Amo o Meio Bit e amo Lost..

Contem logo! To morrendo de curiosidade aqui![...]

oemaildoal $\cdot 3$ anos atrás

repararam no nome da imagem?

WindowsLiveWriterAlgoMisteriosoVaiAcontecer_92BDlostnumbers_2.gif

não deve ter nada a ver com Lost ô.o

Post 6: GVT anuncia GVT TV e miraculosamente foge do mais do mesmo, publicado no MeioBit em 16/09/2011

Treck • um ano atrás

hahahah adorei as fotos temáticas dos pacotes deles![...]

Como parte de uma corte, ou na tentativa de fazer parte dela, é comum buscar "imitar" a figura de maior destaque dentro do grupo. Uma das formas de 
fazer essa "imitação" se torna possível a partir do conhecimento acumulado sobre os assuntos abordados por Cardoso em seus posts. Ao equiparar-se ao blogueiro, em níveis de conhecimento e de gostos pessoais, o próximo passo seria o de encontrar uma abordagem, uma forma de humor e interpretação de piadas e, assim, chamar atenção dentro do grupo usando esses artifícios. Sendo assim, os(as) iniciados(as) conhecem a etiqueta dos ambientes digitais, sabem a linguagem "apropriada" e o que chamaria atenção e, ainda, sabem identificar os(as) diversos(as) participantes desses ambientes.

Os (as) iniciados(as) sabem, de certa forma, o que esperar de Cardoso. Para aqueles(as) que acompanham os blogs de Cardoso há algum tempo e com certa frequência, sabem que o blogueiro costuma inserir códigos, referências, ou seja, deixar alguma explicação subliminar para seus (suas) leitores(as). Por conta disso, todos(as) que conseguem percebem essas sutilezas seriam considerados(as) iniciados(as). Além disso, ao conhecer o universo da cultura geek, ao qual Cardoso se refere quando deseja colocar mensagens subliminares, o(a) comentarista que consegue captá-las se sente como parte do grupo.

Os(as) próprios(as) comentaristas tentam buscar tantas referências quanto possíveis ligadas ao assunto explorado no post. Paralelamente à explicação de piadas, sarcasmos e ironias, essa seria uma forma de aproveitar-se do estilo de humor de Cardoso e fazer a sua própria piada/referência a partir do material publicado por Cardoso. Algumas vezes, o próprio blogueiro elogia a inferência do(a) comentarista. Essa forma de participação pode chamar a atenção de outros(as) comentaristas que, por sua vez, elogiam ou complementam a referência feita, gerando uma "thread" paralela decorrente da forma pela qual o(a) comentarista fez uma piada ou uma referência.

Os(as) iniciados(as), quase sempre, costumam ostentar saberes como forma de se diferenciar dos(as) demais comentaristas. Demonstrando, ainda, proximidade de Cardoso. Esses saberes indicam alinhamento com as ideias de Cardoso e de sua corte e destacam a sua participação, especialmente, quando recebem atenção de Cardoso.

A interpretação correta de referências, piadas e sarcasmos, aos olhos do blogueiro, parece ser considerada uma forma de elogio. Ou seja, uma vez que alguém interprete corretamente uma ideia contida em um posts, segundo os 
preceitos de Cardoso, este(a) comentarista reconheceria a qualidade dessas informações e daria legitimidade para que o blogueiro continuasse a produzi-las.

Ser iniciado(a) no circuito-Cardoso compreende o uso adequado de referências, piadas, sarcasmos e ironias sob a aprovação do blogueiro. Além disso, os(as) iniciados(as) costumam colocar suas próprias referências, conectando-as aos assuntos abordados por Cardoso nos posts. Isso só se torna possível mediante o conhecimento acumulado pelos(as) comentaristas e, principalmente, o alinhamento com os posicionamentos e opiniões de Cardoso.

- Ironias, Piadas, Referências e Sarcasmos próprios de Cardoso e de sua Corte

Os(as) comentaristas iniciados(as) nas "artes" da corte de Cardoso perpetuam a persona digital de seu enunciador ao usarem de artifícios semelhantes aos do blogueiro quando fazem seus comentários. No Blog do Cardoso, no Contraditorium e no MeioBit, esses indivíduos parecem ficar à vontade para publicar, com suas próprias palavras, sarcasmos, ironias, piadas ou referências alinhadas àquelas que o blogueiro usa na elaboração de seus posts. Podemos falar que ao manifestar-se dessa forma, os(as) comentaristas iniciados(as) expressam concordância e admiração, além de uma aproximação, em termos de performance, de Cardoso. Por sua vez, as ironias, os sarcasmos, as piadas e referências selam o sentido de grupo e reforçam a segregação existente nas seções de comentários dos blogs analisados.

Post 1: Ou dá ou desce, Bispo Macedo, publicado no Blog do Cardoso em 01/12/2005 - 1.181 comentários

Igor. 355 weeks ago

A propósito: montei uma igreja evangélica ao lado de minha casa de tolerância e meu ponto de venda de coca.

Ninguém quer ser meu fiel não? :-p[...]

suely 346 weeks ago

vc vai se ver com o SENHOR dos exercitos por difamar um homem de DEUS seu idólatra!!!

Elvis. 346 weeks ago

Sabe Dona Suely,

eu adoro cachorros, principalmente os da raça Pastor Alemão. Comprei um por volta de 2 anos atrás e o nome dele é SENHOR.

É por esse motivo que eu coloquei um adesivo no meu fusca bala "O SENHOR é meu PASTOR" 
Post 2: Exclusivo: As fotos do acidente do vôo 1907 da Gol de dentro do avião, publicado em 26/10/2006 - 1.106 comentários

(Cobra) Bruna Gilberta Mulle. 319 weeks ago

Caro senhor,

por favor retirar essas fotos, pois elas estão sendo utilizadas sem o devido direito autoral. A memória do meu pai precisa ser preservada e respeitada.

Eu e minha irmã Beatriz estamos muito mal e deveríamos ser mais respeitadas em nossas dores. Por favor, se você tiver algum modo para me comunicar com o Major Antonio Nelson, gostaria de ter acesso aos bens pessoais, principalmentes a máquina digital de meu querido pai.

Bia G. Muller· 319 weeks ago

Querida mana,

Por favor, entre em contato comigo.

Recebi um comunicado das Forças Armadas dizendo que um sujeito com sotaque árabe fez contato via rádio e cominicou que nosso querido pai está vivo, perdido em uma ilha no meio do Oceano.

O problema é que papi não quer mais voltar. Parece que um tal de Santoro o acolheu em sua barraca e ele não quer mais saber de sua vida pregressa.

Vamos fazer uma busca tão logo o Major Nelson consiga localizar a ilha no Google Earth.

Beijos, maninha.

Post 3: Haiti - terra amaldiçoada por Deus, publicado no Contraditorium em 13/01/2010 - 133 comentários

Mário José Serran. 151 semanas atrás

Muito justo esse deus.

Enchentes, Terremotos, vulcões, secas, tempestades de neve, guerras, fome, pobreza, tráfico de drogas, assaltos, estupros, assassinatos, latrocínios, sequestros, roubos, mendicância, políticos corruptos, impunidade, ignorância, mentiras, inversão de valores, pedofilia, doenças incuráveis...

Como diria um personagem de novela:

"-É justo, muito justo, justíssimo"

Louvai ao Senhor e glorificai seu Santo Nome!!!

Mucho. 151 semanas atrás

Só faltou você citar os shows de patinação no gelo. :)

Mário José Serran· 149 semanas atrás

Esqueci.

Este Dr. Alzheimer...!

Post 4: Por favor, não matem os meus heróis, publicado no Contraditorium em 25/01/2011 - 105 comentários

Catty M. 98 semanas atrás

Imagino que o conceito ideal de super herois para essa psicóloga seria a banda Restart salvando o mundo com suas músicas felizes e coloridas.

leonardolimaq 98 semanas atrás

nossa, num dá idéia. Se eu fosse produtor deles eu acharia essa sua idéia de uma fodacidade tão grande que, aposte: EU FARIA ESSE QUADRINHO.

Nossa, ia dar muito dinheiro, imortalizar a banda e bla bla bla.

Flávio Harakiri 98 semanas atrás

Esse seu comentário me fez pensar e apenas uma palavra surgiu:

- MEDO!

Gostei do texto, Cardoso!

Post 5: Playstation 3 com precinho camarada - R\$ 7980,00, publicado no MeioBit em 30/11/2006 - 38 comentários 
HotBeam • 6 anos atrás

Vendo uma mãe usada e um rin semi-novo (total-flex).

Tel: 555 6924[...]

Post 6: Brasil e Moçambique vão cooperar no desenvolvimento científico, publicado em 25/11/2008

Finnishh • 4 anos atrás

Gostei do Startack do jovem Maputo.

Kadu Lima • 4 anos atrás

Cuidado, novo iPhone killer!

Se for como da foto do guri será iCrap! :D

A seção de comentários é, de certa forma, uma continuação do próprio post de Cardoso através do olhar de seus(suas) comentaristas. Consequentemente, a linguagem peculiar, adotada por Cardoso em suas publicações, será notada nas abordagens feitas pelas pessoas que comentam e que fazem, ou pretendem fazer, parte de sua corte. Mesmo quando esta abordagem reprime ou discorda da forma pela qual Cardoso tratou determinado assunto. À medida que os comentários se acumulam, a quantidade dessas manifestações dá a noção da popularidade do blogueiro em seu circuito-blogue, bem como da visibilidade que esse circuito tem.

As ironias e sarcasmos dos(as) comentaristas dão continuidade tanto ao estilo e à persona de Cardoso quanto às manifestações de repúdio aos posts do blogueiro. Se a continuidade do estilo de Cardoso é percebida nos comentários que incorporam um estilo de performance que seria caro ao blogueiro, o repúdio também contribui para que esta forma peculiar de comportamento seja repetida. A continuidade, por meio do repúdio, é notada quando os(as) comentaristas que discordam das opiniões de Cardoso passam a responder os comentários favoráveis. A ideia principal, perpetuada nos comentários que concordam com Cardoso, é rebatida repetidamente e, a cada participação “desfavorável”, percebemos que a "defesa" de Cardoso aumenta.

A existência de um acordo tácito, no qual se concebe a ideia de uma corte para Cardoso, revela a noção de grupo, na qual a maioria tem opiniões parecidas com o blogueiro - ou pelo menos assume publicamente esses posicionamentos para fazer parte do grupo. A corte de Cardoso, por sua vez, adota uma linguagem peculiar para trazer ou afastar do grupo pessoas, de acordo com o tipo de opinião expressada.

As performances nas seções de comentários do Blog do Cardoso, do Contraditorium e do MeioBit contribuem, logicamente, para a promoção e 
visibilidade do circuito-Cardoso. Ao repetir atitudes que seriam caras ao blogueiro, os(as) comentaristas aceitam a posição de destaque ocupada por Cardoso e, especialmente, concordam com suas ideias. Por meio dessas posturas, esses indivíduos criam uma cultura identificadora do grupo para esses ambientes, revelando, por conseguinte, linguagens próprias, hierarquias e valores aceitos coletivamente.

- $\quad$ Explicando Ironias, Piadas, Referências e Sarcasmos

Por diversas vezes, encontramos comentários de visitantes que, segundo Cardoso e sua corte, não conseguiram interpretar os sarcasmos, as ironias, as piadas e referências contidas nos posts. Segundo o blogueiro, para que isso seja possível, bastaria somente que o(a) comentarista se desse o trabalho de ler o post por inteiro para, enfim, publicar alguma opinião a respeito dos assuntos tratados na postagem. Ou ainda, buscar definições que explicassem os pontos que não puderam ser compreendidos.

Alguns(mas) membros(as) de sua corte, por seu turno, se sentem na obrigação de esclarecer as ideias contidas nos posts em análise. Por essa razão, encontramos diversas participações cujos objetivos principais eram o de explicar toda a sorte de referências inseridas por Cardoso nos posts. Tais referências funcionariam como "pegadinhas e elementos-chave, capazes de mudar, segundo o blogueiro, toda interpretação acerca das ideias contida nos posts.

Post 1: Responda rápido: Isso aconteceria na Suécia?, publicado no Blog do Cardoso em 27/11/2008 - 99 comentários

Crow. 207 weeks ago

Na verdade, acho que a Suécia está apenas para ilustrar um país de primeiro mundo com um PIB alto. Poderia ser qualquer país de primeiro mundo alí.

\footnotetext{
Álvaro. 200 weeks ago

Como?? apenas para ilustrar é? Eu tenho a opinião que se vc for falar de algo vc tem q ter dominio sobre o tal assunto, não é correto nem sábio dar exemplos que não condizem com a realidade.
}

Gustavo- 151 weeks ago

Não só não teve graça nenhuma, como foi completamente imbecil. Piadinha de menino de 12 anos.

Eliezer. 151 weeks ago

Gustavo,

Até entendo que alguns achem de mau gosto. Quem conhece o Cardoso sabe que "há muito mais entre o céu e a terra do que sonha a nossa vã filosofia". De qualquer forma, além de dizer que você não conhece o Cardoso, tomo a liberdade de dizer que sua leitura não é nada 
boa! Mesmo achando injusto, desrespeitoso, ou sei lá o que, nada que possa ser dito chegaria perto de "piadinha de menino de12 anos". Bem, não conheço um menino de 12 anos com tamanho capacidade! As imagens (tudo bem, UMA imagem duplicada) mostram que a coisa lá SEMPRE foi muito feia. O Cardoso (e muitos outros aqui) sabe que não é apenas um país pobre, mas corrupto até o pescoço.

Bem... talvez você conheça o Cardoso a ponto de dizer que ELE seria capaz de dizer isso com 8 anos. Se é o que quer dizer, desculpe-me... e parabéns ao Cardoso.

Insisto em dizer que sou NEUTRO quanto ao POST. Entendo quem acha de mau gosto, mas entendo também a postura do Cardoso, que não os considera simplesmente pobres coitados que tiveram "azar" na vida.

Post 2: Perdendo a fé na humanidade, publicado no Contraditorium em 07/08/2007 - 67 comentários

Flávio Ayala. 278 semanas atrás

Olha, eu estava acreditando na imbecilidade do indivíduo, mas quando li "Pai Cardoso" ficou claro que ele estava sacaneando.

Mas, valeu pelo post, ri um bocado. :-)

Post 3: Atendendo a pedidos - mais ou menos, publicado no Contraditorium em 03/12/2008 - 109 comentários

Eduardo 215 semanas atrás

Não entendo esses ânimos exaltados que as vezes surgem em "discussões" na internet... Alias, talvez seja porque aqui as pessoas comecem à criar personalidade uma personalidade diferente. Tanto que é difícil imaginar essas discussões tomando esse rumo estando "frente a frente".[...]

O Cardoso com essa foto que ele tirou provavelmente pensou que ironizando os comentaristas ele estaria por cima, porém nada acrescentou ao assunto que fizesse esses comentaristas mudarem de opinião...

Daqui a pouco os comentaristas voltarão e vão dar outras respostas também que não acrescentarão nada, mas aí será a vez deles acharem que estão por cima...[...]

Eduardo 215 semanas atrás

Ninguém está dizendo que isso tá certo ou errado, ou que isso deveria ser policiado.

Mas não há como negar que essa forma de agir é paralelo como o das Drag Queens. Covarde no mundo, e corajoso no PC.

O problema que isso gera é que como uma pessoa se torna inatingível, não se tenta dialogar pra resolver as desavenças, e cada vez mais tempo desperdiçado com intrigas...

E não estou falando desse caso em especial. Estou falando que de um modo geral...

Mas cada um sabe o que faz...

Cláudio Abelardo 215 semanas atrás

Achei perfeito isso, pensar como o curinga é essencial...

Já era seu fã, depois dessa fiquei mais ainda...

Abraços,

Regina Salitre. 214 semanas atrás

Gostei da acidez, muito melhor do que o politicamente correto que faz com que muitas pessoas acabem no balaio dos demagogos. O lance da cerveja foi ótimo.

Evandro Richa· 215 semanas atrás

E o que voce acha que ele faria pra mudar a opnião das pessoas?

Gente que escreve e pensa aquilo lá, não tem como argumentar.

Ou voce queria que o Cardoso se culpasse por ter (ou não) um $4 \times 4$ ?

Ou ainda que ele voltasse atrás e confirmasse que ta certo roubar um whiskie?

Eduardo· 215 semanas atrás

Quem disse que eu estava falando só do Cardoso? Eu estava me referindo aos dois lados.

Ambos fugiram do assunto pra falar de coisas que não tem nada a ver e tentar sair como o vencedor do debate... Esperando que os outros comentaristas(uns e outros são baba-ovo do 
Cardoso), falem algo do tipo, "Cardoso matando a cobra e mostrando o pau!" pra inflar seu ego.

Celião 215 semanas atrás

Cardoso matando a cobra e mostrando o pau!!! :o)

Post 4: TechEd 2008 - Linux marcando presença, publicado no MeioBit em 15/10/2008

Zumbiamarelo -> Lump • 4 anos atrás

[...]Carlos Cardoso disse:

Um pobre usuário nem um pouco leigo

PEGADINHA DO MALANDRO RÁAAA

Cardoso, você vai pagar por isso um dia $\}:)[\ldots]$

Paraquedista -> Lump • 4 anos atrás

[...]Vou te falar outra coisa que não ficou claro para você: $\mathrm{O}$ Cardoso estava tirando onda de você. Ele SABIA como resolver o problema, mas não podia perder a piada (sim, você foi a piada).

[...]E POR FAVOR! Use o link responder ali em baixo.

Dogmatch $->$ Paraquedista $\bullet 4$ anos atrás

Agora tá esclarecido. Por favor me ensina como aumenta a percepção.

Post 6: Linux atinge a marca histórica de $1 \%$ do mercado, publicado em 02/05/2009 - 365 comentários

lúcio $\rightarrow$ pauloabel $\bullet 4$ anos atrás

O cálculo é feito com base nos acessos aos sites monitorados pela NetApplications.[...]

Essa estatística lida com o uso do computador no quesito de acesso a internet, sendo assim, ela é mais relevante do que uma estatística baseada em vendas.[...]

Ksturino $\rightarrow$ lúcio• 4 anos atrás

Uma pesquisa da revista acadêmica Intelligence defende uma tese de que pessoas com QI (Quociente de Inteligência) mais alto são menos propensas a utilizar de hábitos e costumes populares e também menos propensas a ter crenças religiosas.[...]

Se conformem, o linux pode chegar até no máximo $5 \%$ de base de usuários.

Eu acho bastante, é só as empresas focarem a venda do Linux pro nicho correto...[...]

Explicar os posts de Cardoso pressupõe assumir uma postura de "proximidade" do blogueiro, embora esta seja pela concordância e/ou similaridade na forma de pensar sobre os assuntos abordados. Principalmente, quando esta manifestação é feita antes dos(as) demais, pois demonstra que o(a) comentarista acompanha Cardoso frequentemente. Ser "desbravador(a)", como vimos, é uma forma de conquistar uma posição especial em um grupo, especialmente no grupo de geeks ao qual o blogueiro se dirige.

A explicação das piadas, sarcasmos e ironias é observada nos momentos em que aparecem vários comentários de pessoas que, no entender dos(as) membros(as) da "corte de Cardoso", não souberam interpretar o sentido aceitável por eles(as) da colocação inserida nos posts do blogueiro. Normalmente, os(as) comentaristas que fazem essa explicação buscam ser os primeiros(as) a 
demonstrar esse entendimento, como forma de enaltecer suas habilidades e de mostrar que, além da admiração por Cardoso, é parecido(a) com o blogueiro.

Ironicamente, na sabedoria popular, explicar uma piada não é algo bem visto, pois acaba por tirar-lhe toda graça. Justamente pela sutileza do humor, o que se conta acaba chamando atenção pelas associações e pelas referências. E, no momento em que isso é explicado, deixa de ser engraçado - fazendo uma breve analogia: os "ingredientes" que possibilitaram a construção do humor são revelados e o que torna a piada uma piada se perde; assim como na relação entre fachada e bastidores proposta por Goffman (2002).

No âmbito do circuito-Cardoso, explicar uma "piada" é uma forma de mostrar ao blogueiro que o(a) comentarista conseguiu perceber as ironias, os sarcasmos ou as referências. Ainda, caso a piada não seja totalmente explicada, como acontece nos casos em que se citam outras referências para a "piada" em questão, o(a) comentarista assume uma postura de que além de ter interpretado, conhece o assunto tão bem quanto Cardoso.

Nesse caso, a explicação dessas piadas, sarcarmos e ironias - assim como das referências à cultura geek -, acaba por funcionar como uma forma de impor um estilo performático para aqueles(as) que não estão acostumados àquele ambiente. Essa imposição diz respeito aos modos de dizer, detalhadamente, os mecanismos que tornam os posts de Cardoso e o próprio Cardoso o que são. Quem não consegue perceber as sutilezas e os detalhes, necessitando a todo instante de uma explicação, não deveria frequentar esses espaços. Por essa razão, estes(as) comentaristas estão sujeitos aos "rótulos" pejorativos criados pelo grupo.

Diferentemente da explicação de uma piada normal, esse comportamento não torna a proposta contida nos posts menos engraçada, menos irônica ou sarcástica. Como podemos notar, devido à dinâmica presente em sua seção de comentários, muitos(as) continuam a "parabenizar" ou a criticar o que está no post, tendo em vista que a explicação é uma atitude que parte de corte de Cardoso. Logo, para aqueles(as) que discordam da atitude do grupo, não podem ser consideradas.

Ainda, a explicação é uma forma de poder, proporcionada pelo entendimento e pelo apoio às ideias e ao comportamento de Cardoso. Uma vez que alguém entenda e seja o(a) primeiro(a) a mencionar isso, na forma de comentários, esta pessoa recebe destaque. Consequentemente, este indivíduo teria 
abertura e visibilidade em outras ocasiões em que comentasse. Entretanto, essa abertura e destaque merecem ser detalhados. O "nome" do(a) comentarista continuará a ser lembrado mediante novas e contínuas participações nos blogs de Cardoso.

\section{- A Corte de Cardoso}

O fato de Cardoso ter sempre razão em seus blogs revela uma importante característica, relacionada aos(às) comentaristas desses espaços. Por exercer um gerenciamento "a mãos de ferro" sobre as ideias que circulam nas seções de comentários do Blog do Cardoso, do Contraditorium e do MeioBit, Cardoso acaba por categorizar as suas audiências. Uma dessas classificações determina aqueles(as) mais ou menos privilegiados(as) nesses ambientes. Os menos(as) privilegiados(as) recebem alcunhas que chegam a ser consideradas pejorativas tanto dentro quanto fora desses ambientes digitais.

Os(as) privilegiados(as) parecem conhecer bem Cardoso, chegando a antencipar o que o blogueiro pensa, como ele se comportaria em determinadas situações e, é claro, concordam com todas as suas opiniões e o defendem sempre que possível. Em alguns momentos, tais comentaristas são chamados de "puxasacos", de "seguidores de São Cardoso", dentre outras denominações. Nesse trabalho, esses(as) comentaristas fazem parte da corte de Cardoso.

Post 1: Ou dá ou desce, Bispo Macedo, publicado no Blog do Cardoso em 01/12/2005 - 1.181 comentários

Zé_das_Couves. 306 weeks ago

[...]Engraçado é que a tática do "ataque é a melhor defesa" vale até pra esse bando de zumbis. Tem um fulano aí que se diz jornalista, mas pra atacar acusa o cara de "bixa" (que caralho é isso?). Porra;

1. O Cardoso já disse que não é homofóbico.

2. Quem tenta atacar os outros dessa maneira deve estar com a maior vontade de dar o vanaro, mas não tem coragem(Não se preocupe caro amigo desejoso. Mais viado do que quem dá é aquele que fica de pau duro quando vê um cu cabeludo com cheiro de macho, afinal de contas é por isso que quem come é que é chamado de homossexual ativo - tá certo, o seu é raspadinho, mas ainda assim fede a macho).

3. Os outros comentários desses jumentos eu não consegui decifrar. Ainda não aprendi a ler russo.

4. Se essa bosta dessa igreja é tão boa (e me refiro especialmente à Universal) pq vcs perdem tanto tempo na internet? Vão rezar seus excomungados, pq de outra forma quem vai parar nos quintos dos infernos são vocês.

Sem mais.

Isaías, o profeta.

Post 2: Imagens exclusivas: terremoto no Haiti, publicado no Blog do Cardoso em 12/01/2010 - 215 comentários 
Sisudo. 152 weeks ago

Vão a merda o que ocorreu é muito sério....... Suas Crianças de Bosta e de Merda...... seus

Kakas na fralda........]

Roberto Sviski 152 weeks ago

Crianças é quem fica de mimimi após uma brincadeira.

Pessoas morrem todo dia, seu post choramingando não vai adiantar de nada ó seu Sério.

Sempre há falsos moralistas.[...]

André. 152 weeks ago

Nem pra xingar esta criatura serve. Chame o cara de viado, corno, FDP, chame pra porrada. O emo só faltou dizer "Vô contá pra minha mãe! Mãe, ó o Cardoso, ó!"

Luthor. 151 weeks ago

Ficou ofendidinho...... Posta teu nome, teu email, SEJA HOMEM, MOLEQUE DE MERDA!

É o típico cara classe média descrito no último tópico do Blog Classe Média Way Of Life.

É amigo... mor é assim mesmo. Não gostou?

Se Está tão Ligando Pro Haiti, Vai Lá Ajudar... Ou Hospeda Um Pessoal Na Sua

Casa... Ou Arrecada Alimentos...[...]

tião. 151 weeks ago

Cara... piada infeliz mesmo. Se tua mãe tivesse morrido lá tu faria a mesma piada ?

Gabriel. 151 weeks ago

E me explique porque o Cardoso ou qualquer um deveria se colocar no lugar de alguem? Isso é a coisa mais imbecil que eu já ouvi.

Eu acho minha vida e meu bem-estar muito mais importantes do que $99,99 \%$ das pessoas.

Se voce não pensa assim, se mate e doe todos seus orgãos, há muitas pessoas que precisam...

Post 3: Atendendo a pedidos - mais ou menos, publicado em 03/12/2008 - 109 comentários

Grattari 210 semanas atrás

Excelente post. Os comentários infundados dos leitores me proporcionaram boas risadas. Tenho certeza que estes leitores que criticaram seu post sobre os animais sequer se prestaram para ler até o final, ou, se leram, não entenderam o ponto abordado.

E digo mais: os únicos peixe mais detestáveis que as focas, são as baleias. Ô peixinho espaçoso com mania de encalhar!

Post 4: Por favor, não matem os meus heróis, publicado no Contraditorium em 25/01/2011 - 105 comentários

golias duarte. 98 semanas atrás

A opinião da Sra. citada não difere da opinião de qualquer psicólogo que aparece nos Jornais da Globo para falar sobre assuntos "polêmicos" como bullyng, videogames violentos e brigas escolares.

Não dá pra dar credibilidade.

C. Emanuel Laguna Jr. 97 semanas atrás

Concordo, mas tal emissora deve fazer isso apenas porque o povão dá audiência e essa gente toda está pouco se lixando para a fidelidade dos detalhes nas pautas abordadas, ou mesmo se tais pautas possuem alguma parcialidade em meio à imparcialidade com a qual a empresa de comunicação tanto se gaba.

Post 5: Brasil e Moçambique vão cooperar no desenvolvimento científico, publicado no MeioBit em 25/11/2008 - 396 comentários

Freddy Liverpool $\bullet 4$ anos atrás

Sinceramente em matéria de tecnologia Cardoso tem até algumas coisas úteis, mas em se tratando em matéria de política e relações internacionais esta ironia e superficialidade chega a ser uma decepção.

Não sou o Jonny Walker, mas walk mais que ele...

UranoTienn $\rightarrow$ Freddy Liverpool• 4 anos atrás

Mas cara, ele ate tem bons momentos, mas a maioria é feita de sarcasmo fraco.

Todos os seus posts que fogem da tecnologia tem visões extremamente infantis. 
Chega a ser engraçada a diversidade do Meiobit, tem o cara da fotografia, o cara mais tecnico, a menina apple, o que posta um pouco de tudo e o bobo da corte entre outros

Graça $\rightarrow$ UranoTienn $\bullet 4$ anos atrás

Urano,

Olá!

Fiquei curiosa o que levaria tão nobre e perclaro cavalheiro a se interessar por uma 'reinado' com uma 'nobreza' tão insossa (conforme seu relato) quanto à do Meiobit....masô mesmo?

[...]

UranoTienn $\rightarrow$ Graça 4 anos atrás

Pq disse que o MeioBit é insosso?

Só pq leio o meiobit não posso discordar de alguns pontos?

Sempre leio o meiobit e o meiobitgames, acho um otimo blog

Leio quase tudo, só nao leio mesmo os de fotografia pq nao me interesso nada por essa area, nada contra o cara da fotografia.

Mas tem vezes que o Cardoso exagera ne, ai a comparação caiu bem

Minha simples opiniao, cada um tem a sua

Graça $\rightarrow$ UranoTienn• 4 anos atrás

[...]Não disse que vc disse que o meiobit é insosso. Leia novamente:

Meiobit $=$ 'reinado'

Nobreza do reinado $=$ editores $/$ postadores

$[\ldots]$

Barba $\rightarrow$ Graça $\bullet 4$ anos atrás

Ele é do brejo, Fatima.

Pryderi $\rightarrow$ Graça $\bullet 4$ anos atrás

Olha, eu sugiro que vc converse com um hamster com sindrome de Down. Vc terá melhor proveito na conversa.

$[\ldots]$

ClaroEscuro $\rightarrow$ UranoTienn $\bullet 4$ anos atrás

Só com esse post mostrou como vc tem uma visão infatil e simplista de tudo, inclusive dos editores do meiobit.

$[\ldots]$

michelfernandes $\rightarrow$ ClaroEscuro $\bullet 4$ anos atrás

Baba ovos de plantão ?

ClaroEscuro $\rightarrow$ michelfernandes $\bullet 4$ anos atrás

não. não preciso ficar puxando saco de ninguem.

porém resumir as pessoas do jeito que ele fez é totalmente a mesma coisa na qual ele acusou os outros. simples assim.

e vc... revoltadinho de plantão?

parece criança birrenta que se alguém fala algo contra já acusa de puxação de saco.

$[\ldots]$

Assembly $\bullet 4$ anos atrás

LoL, o Cardoso é muito foda! Ele consegue causar rebuliço mesmo quando escreve coisas desprovidas de sentido![...]

Post 6: Asus vai incorporar Splashtop Linux em todas as suas placas, publicado no MeioBit em 15/05/2008 - 190 comentários

Carlos Cardoso $\rightarrow$ Vanna $\bullet 4$ years ago

Você vai mesmo perder seu tempo discutindo com alguém com nickname "debian"?[...]

ch1nes $\rightarrow$ Carlos Cardoso $\bullet 4$ years ago

Melhor do que perder tempo com alguem que utiliza termos como "freetards" em um monte de palavras que tem a ousadia de chamar de artigo. Realmente, esse (meio)site faz juz ao nome (meiobit), com seus meio-autores com metade de um cérebro ;)

Ora, por favor... isso aqui tem a pretensão de servir como fonte de informação ou é apenas seu blog pessoal?

Gabrielrbd $\rightarrow$ ch1 nes $\bullet 4$ years ago

Tem pessoas que não levam certas coisas na esportiva, eu uso Linux e sou feliz, vendo que o MeioBit é um blog "pessoal" comunitário as pessoas deveriam ter em mente que os autores falam e dão sua opinião pessoal sobre as noticias de outros sites, agora oque tu não 
pode fazer é dar a tua "opinião" sobre a opinião deles e dos seguidores deles. Quer dar tua opinião, fique a vontade, mas antes pense bem se vale a pena ;)

Leve na esportiva, de boas gargalhadas e discuta com teus amigos e colegas sobre as coisas "fúteis" que vc ve aqui e faça bom proveito, eu por exemplo, alem te ter a noticia quente tenho a opinião dos outros para poder discutir com meus amigos e colegas, use as informações da maneira certa, fica ai minha dica para os "revoltados" que agem sem pensar :)

Balboa $\rightarrow$ ch1nes $\bullet 4$ years ago

Blog Pessoal, onde os artigos refletem diretamente a opiniã do autor...

Próximo....

[...]

ch1nes $\rightarrow$ Balboa $\bullet 4$ years ago

Prezado senhor paga-pau Balboa,

[...]Analise a seguinte frase:

"Não apoiamos sistemas, empresas ou produtos específicos, a idéia é ter vários colaboradores com diferentes interesses e opiniões, e assim trazer um editorial balanceado" Agora, um ser que se intitula autor (Carlos Cardoso), que utiliza termos como "freetards" e critica de forma visivelmente pejorativa usuarios de determinado sistema está longe de ser balanceado e é claramente tendencioso.

Inclusive, a pergunta inicial que fiz se isso é um blog pessoal ou uma tentativa de ser algo sério não foi dirigida a voce, entao, com licença.

Carlos Cardoso $\rightarrow$ ch1 nes $\bullet 4$ years ago

Um blog pessoal não pode ser sério?

Ah, esses freetards me divertem. Continuem assim. A Microsoft agradece.

PS: Você não tem moral NENHUMA de cobrar seriedade, no momento em que no campo "profissão" do cadastro no MeioBit coloca "troll", ok:?

ch1nes $\rightarrow$ Carlos Cardoso $\bullet 4$ years ago

[...]Se eu colocar na minha profissão qualquer outra coisa, digamos, "caixa de supermercado", voce deixa de ser retardado? Para de postar coisas idiotas e tendenciosas? Certeza que nao.

Ou voce vai dizer que um caixa de supermercado nao tem moral pra receber uma resposta sua?

MaRiauM $\rightarrow$ ch1nes $\bullet 4$ years ago

Meu caro,

ninguém aqui tem a obrigação de concordar com o Cardoso nem com qualquer outro usuário/editor do Meio Bit.

As notícias não são imparciais, refletem a opinião do autor, por isso há este espaço para discussão!

Eu já entrei em flames com o Cardoso, com o Fabião, com o QBBFTWGMO, com o Ubirajara e com diversos outros. Foram discusões inflamadas, cada um defendendo o que acredita, afinal são pontos de vista diferentes, mas em nenhum momento faltamos com respeito. Além do mais, foram discussões com conteúdo e não esse ataque direto e insensato que você vem demonstrando.

Antes que você me chame de "paga-pau" ou algo do gênero, quero lembrar: Não acho correta a maneira que o Cardoso escreve alguns tópicos, de maneira tendenciosos e demasiadamente irônica, já critiquei isso em outros post e nem por isso possuo uma insígnia de troll.

Aprenda a argumentar com respeito e conteúdo, sem isso você não pode ser levado a sério![...]

ch1nes $\rightarrow$ MaRIauM $\bullet 4$ years ago

[...]Bom, voce pode nao faltar com respeito, como tenho visto em seus posts, mas vejo que o carinhoso termo "freetard" é usado com frequencia nesse pseudo-site. Sem contar a (falta de) argumentos utilizada, como questionar a idade/emprego de quem posta, e por ai vai.

[...]Bom, voce falou do meu "ataque direto e insensato", quer coisa mais direta e insensata do que ofender publicamente toda uma comunidade de pessoas chamando-as de freetards na pagina inicial do site?

Se algumas pessoas sao "freetards", clara alusão a retardados, por que o autor desse site chamado carlos cardoso tambem nao pode ser chamado da mesma forma?

MaRIauM $\rightarrow$ ch1nes $\bullet 4$ years ago 
Cara, o termo freetard não se aplica aos usuários de SL! Nesse exato momento vos escrevo diretamente do meu Firefox rodando sobre openSUSE e não sou freetard!

$\mathrm{O}$ tard no final de qualquer sistema (Appletard, MStard, freetard, etc.) é para os fanboys chatos que ficam falando mal de qualquer sistema que não seja o seu próprio ou defendendo um determinado sistema apenas por ser o que usa e venera!

Sinto muito, mas (provavelmente) por desconhecer os termos utilizado aqui no MB você se colocou em uma posição de freetard ao sentir-se ofendido por um termo sem saber o que ele significava, apenas pressupondo que se referia a toda a comunidade do SL.

[...]Espero que você tenha compreendido que foi apenas um erro de interpretação e que essa discussão sem sentido tenha um fim, bem como os ataques sem sentido aos outros usuários.

Não quero defender ninguém aqui, mas não vejo vantagem nesse tipo de discussão![...]

Paraquedista $\rightarrow$ ch 1 nes $\bullet 4$ years ago

Meus \$ 0,02:[...]

Não é usando termos como "pseudo-site", "um ser que se intitula autor", ou outros termos que irão ajudar na sua questão. Pelo que vi, foi você quem começou com os termos.[...]

Primeiro: qual exatamente a comunidade que ele está atacando? Segundo: você está incluído nela? Vestiu a... melhor deixar assim.

Veja meu nick. De forma alguma fico ofendido quando me chamam de qualquer coisa. Já fui chamado desde freetard a defensor da M\$ (appletard ainda não). Já discuti também com QBBFTWGMO, MaRIauM, Ubirajara e Fabião. Não tenho a mesma opinião deles, mas acabei respeitando bastante cada um deles.[...]

Tente não se ofender com os rótulos e discuta com ARGUMENTOS. Todos saem ganhando.

PS: como faço para também ganhar um cavalinho?

Uma figura de destaque, como Cardoso, para ser legitimada precisa de seguidores(as) que ajudem na propagação/divulgação de seus pontos de vista, além de reconhecerem a sua performance. A "corte de Cardoso" parece assumir esse papel, mostrando-se alinhada às opiniões do blogueiro. São comentaristas que desejam se inserir no grupo ou, ainda, por terem opiniões semelhantes as de Cardoso, acabam por defender suas ideias.

A “corte de Cardoso", portanto, é composta por aqueles(as) que, na seção de comentários, defendem, com todas as forças, os pontos de vista do blogueiro. Em grande parte, são comentaristas que explicam as piadas, que ridicularizam os(as) segregados(as) e, ainda, divulgam as condutas aceitáveis naquele ambiente.

Pelo estilo de abordagem e de participação, são pessoas que buscam os mínimos detalhes nas referências usadas por Cardoso. Por se encontraram neste nível, automaticamente se inserem no séquito especial de seguidores(as) e, consequentemente, acham-se no direito de segregar aqueles(as) que não conseguem interpretar da mesma forma que eles(as).

Os(as) cortesãos(ãs) são aqueles(as) que dão legitimidade para a posição de destaque ocupada por Cardoso. No sentido que colocamos aqui, a "corte de Cardoso" é composta por fãs e seguidores (as), incluindo-se aí algumas 
microcelebridades. No momento em que defendem o ponto de vista de Cardoso, em sua seção de comentários, as microcelebridades são os "amigos (as) do reino" do blogueiro e, naquele instante, são acolhidos (as) como cortesãos (ãs).

O comportamento e a atitude desses indivíduos parecem buscar a preservação da persona digital de Cardoso, de modo que seus posts e a sua participação em ambientes digitais encontre credibilidade.

A “corte de Cardoso" é responsável por dar ressonância às performances e posicionamentos do blogueiro, legitimando a sua persona digital. Tanto por expressar sua concordância com as ideias de Cardoso quanto por, principalmente, formar um séquito que reconhece o destaque contido no papel desempenhado pelo blogueiro no circuito-Cardoso. Ao atuarem na "repressão" de comportamentos considerados inadequados ou de opiniões contrárias aos ideais de Cardoso e, por conseguinte do grupo, a "corte de Cardoso" assume, com o blogueiro, a posição de considerar o que seja aceitável e o que deve ser abolido nas seções de comentários.

Notamos que, em um comentário, um comentarista menciona que qualquer pessoa inteligente não concordaria cem por cento com tudo o que Cardoso escreve, logo deixando margem para que, neste contexto, a "corte de Cardoso" se comporte como o grupo dos (as) segregados (as) que se atém, de qualquer forma, a seu ponto de vista mediado por um discurso maior. Dessa forma, esses (as) comentaristas são vistos com certa ressalva no momento em que comentam, tendo em vista que, em vez de debater alguma ideia, replicam a opinião de Cardoso. $\mathrm{Ou}$ seja, segundo este comentarista, a "corte de Cardoso" seria tão inapta quanto os (as) segregados (as).

Justamente, tal e qual em uma corte, a decisão e a opinião do (a) soberano (a) devem ser respeitadas, tendo em vista que posições estão em jogo. Neste contexto, as posições dizem respeito a tentativas de receber atenção de Cardoso e, assim, conquistar espaço para que, um dia, esses indivíduos possam se tornar microcelebridades. Nesse sentido, a corte luta por um lugar de destaque, sem tentar ocupar o lugar de Cardoso para que, dessa forma, se obtenha visibilidade. Por seu turno, as decisões e opiniões são reverberadas e, assim, passadas hierarquicamente até aos (às) recém-chegados (as).

Na seção de comentários, por sua vez, é a "corte de Cardoso" que recebe reverências e tentativas de obter atenção. Ou seja, seria um meio do caminho para 
se conquistar uma posição dentro da "alta corte" e, assim, alcançar o próprio

Cardoso.

- $\quad$ Cardoso sempre tem Razão

Como vimos, os blogs são páginas pessoais nas quais indivíduos publicam conteúdos que exprimem interesses e gostos pessoais, bem como suas opiniões sobre determinados assuntos. Nestes espaços, blogueiros (as) são os (as) donos (as) e assumem a responsabilidade pelos posts disponibilizados em seus blogs. No Blog do Cardoso, no Contraditorium e no MeioBit notamos que Cardoso gerencia esses espaços com "mãos de ferro", especialmente quando alguém discorda de uma opinião sua. A atitude "controladora" do blogueiro é vista como um dos pressupostos norteadores da criação de blogs: ter um espaço para publicar opiniões do (a) autor (a) sobre diversos assuntos, principalmente ligados a interesses pessoais. O próprio Cardoso explica, em posts e comentários, que, por ter criado os blogs e por estes serem espaços em que o (a) autor (a) pode falar o que quiser, ele não admite ser contrariado. Embora, em alguns momentos, o blogueiro deixe claro que os (as) comentaristas podem expressar suas opiniões sobre o que quiserem sobre seus posts, menos criticá-lo.

Post 1: Ou dá ou desce, Bispo Macedo, publicado no Blog do Cardoso em 01/12/2005 - 1.181 comentários

mauro vitório 308 weeks ago

já vi que sua vida se resuma ao seu "site" e sua família? sua saúde? sua vida sentimental? e o resto como vai? deixe de ser ridículo e fútil relacionando sua felicidade ao seu "site" vc sabe que até a CICARELLI transando bateu record em acessos na internet. o que não leva a nada também faz seus idealizadores acharem que são alguma coisa assim como vc pensa que é. pos isso que o mundo sofreu e sofre em maõs de pessoas como vc centralizadora e formadora de opiniões e sempre vão existir tolos iguais a vc para ir para o inferno junto contigo!

[...]tem bravura nessa cabeça oca? então faz este desafio e antes de vc ir para o inferno me mande um e-mail que eu orarei por vc até pessoalmente nem que seja em um manicômio ou hospital ou preso entre as ferragens e DEUS lhe perdoará!

Cardoso 308 weeks ago

Mas é CLARO que meus problemas são culpa minha, não ponho a culpa no coitado do Demônio, como você e os outros seguidores desse seu Amiguinho Imaginário colocam.

E sinceramente, no momento em que você defende os picaretas do macedo e dos dois pastores presos, você mostra o quão BURRO é. Sério, já fez um ECG? Vai dar linha reta...

Post 2: O que é pior:Matar 20 Milhões de pessoas ou Sacanear um Pedaço de Pão, publicado no Blog do Cardoso em 15/01/2009 - 58 comentários

Angelo. 203 weeks ago

Cardoso, certamente você não entende o problema a ponto de emitir uma opinião fundamentada, o que é, no mínimo, leviano. OK, reconheço que é seu direito, afinal, 
nesse país, todo mundo tem de ter uma merda de opinião sobre tudo, mesmo que não entenda bulhufas sobre o assunto. Mas daí a fazer pouco-caso da fé alheia, insultando o que há de mais sagrado na religião católica, a saber, a hóstia consagrada? Faça-me o favor. Me senti profundamente ofendido enquanto católico.

[...]Critiquem à vontade, mas respeitem a fé das pessoas.

Cardoso. 203 weeks ago

O que há de leviano em centenas de milhões de dólares de indenizações para crianças molestadas por padres, só nos EUA?

E claro que é meu direito achar IDIOTA alguém considerar mais sério cuspir em uma merda de um biscoito do que cometer genocídio.

EU me sinto profundamente of endido enquanto SER HUMANO por saber que gente como você considera a vida de um semelhante menos importante que um biscoito.

Post 3: Haiti - terra amaldiçoada por Deus, publicado no Contraditorium em 13/01/2010 - 133 comentários

Alan Noda· 152 semanas atrás

Olha Cardoso, o problema não é fazer piadas sobre questões políticas ou desgraça de um povo, pois o humor é a forma mais sagaz de se criticar quem está no poder administrando mal dinheiro alheio, seja na recuperação de catástrofes ou enfiando dinheiro dentro da meia. Agora fazer comentários impertinentes ou piadinhas no twitter sobre a médica sanitarista Zilda Arns aí já é demais. Claro que você não vai conhecê-la sempre atrás do seu computador sentado nesta cadeira confortável, só conhece a realidade atrás da tela de computador, notícias sensacionalistas e fofocas, porque trabalho beneficente não dá ibope, nem dinheiro na internet, então é melhor se informar ou levantar da sua confortável cadeira, e ajudar ao próximo ao invés de criticar achando que é hipocrisia! Ajude o Fundo da Pastoral da Criança!

Cardoso 152 semanas atrás

Desprezo totalmente sua colocação. É uma calúnia e uma inverdade. Minha cadeira é uma merda.

Post 4: Por favor, não matem os meus heróis, publicado no Contraditorium em $25 / 01 / 2011$

Zukrinar 98 semanas atrás

Acho que não entendi tão bem o que você quis dizer, mas eu concordo em parte com os dois. O que a psicóloga disse se aplica a heróis como o Rambo, que não fazem nada além de matar e mostrar o que é ser foda. É o tipo de herói que você vê em filmes de ação genéricos, tipo Steven Seagal.[...]

Cardoso. 98 semanas atrás

Você então não entendeu NADA no Rambo. Sério, alugue o primeiro filme, assista. Alugue o último assista. Você não sabe do que está falando.

Post 5: Brasil e Moçambique vão cooperar no desenvolvimento científico , publicado no MeioBit em 25/11/2008 - 396 comentários

michelfernandes $\bullet 4$ anos atrás

Agora você se superou Cardoso, o que antes eram críticas incisivas com tom engraçado. Agora, estão se transformando em um discurso rasteiro, em um pensamento sem elaboração nenhuma, baseado no racismo e no preconceito.

Que petulância desqualificar sumariamente um projeto de cooperação, dentre os vários que o país possui, com um outro país de língua portuguesa.

Argumentar alguma coisa neste caso é jogar saliva fora, embora várias pessoas tentem mostrar, como observamos em diversos comentários deste post, outros pontos de vista na discussão.

Carlos Cardoso $\rightarrow$ michelfernandes 4 anos atrás

Racismo o escambau. Eu sou bisneto de escravos, minha certidão de nascimento me classifica como PARDO e tenho até direito a cotas. Me respeite senão jogo-lhe uma Lei Caó.

Preconceito sim. Econômico. Trabalhar pra pobre é pedir esmola pra dois. 
De resto, arugmentar é jogar saliva fora, pois um monte de gente concorda com meu ponto de vista mas você assume que só eu penso assim. Que tal ler os comentários que discordam de você?

michelfernandes $\rightarrow$ Carlos Cardoso $\bullet 4$ anos atrás

[...]Infelizmente você tem razão, muita gente pensa como você.

Post 6: Blue me punto para Microsoft, publicado no MeioBit em 05/10/2007

spadilha $\cdot 5$ anos atrás

Matéria fanboy ou jabá? =P

"Volante executou uma operação ilegal, causando um erro em ControleDosFreios.dll e será desligado." :-O[...]

Carlos Cardoso $\rightarrow$ spadilha $\bullet 5$ anos atrás

Tava demorando...[...]

spadilha $\rightarrow$ Carlos Cardoso $\bullet 5$ anos atrás

Ok, foi só brincadeirinha. :(

Não resisti.[...]

As performances de Cardoso em ambientes digitais acabam por imprimirlhe estilos que são facilmente relacionados ao blogueiro, especialmente entre aqueles(as) que participaram do circuito-Cardoso. A sua fama é proveniente da forma por meio da qual incorpora a sua persona digital, caracterizando uma personalidade considerada, por muitos (as), controversa para a blogosfera.

O estilo de Cardoso é notado tanto em suas opiniões parciais e na forma com que aborda assuntos considerados polêmicos, quanto na escrita, nas temáticas abordadas e no tratamento direcionado a suas audiências. O conjunto dessas ações, assim como o olhar de seu público, acabam por revelar uma persona digital característica.

Os seus blogs, seus textos e conteúdos, assim como seu comportamento, compõem um pacote indissociável. Por essa razão, manter uma postura distanciada, arrogante e grosseira contribui para dar a credibilidade almejada pelo blogueiro aos conteúdos publicados. A persona digital assume um comportamento com ações esperadas pelo público com base em experiências anteriores vivenciadas no circuito-Cardoso. E, o que poderia ser considerado um fato que derrubaria a credibilidade (como as técnicas e artifícios para atrair audiência), acaba por compor a sua personalidade.

A postura, considerada autêntica por membros de sua "corte", interfere, obviamente, para a atração ou para a repulsa. Os(as) comentaristas que concordam chegam a adotar uma postura quase de idolatria, concordando com todas opiniões ou formas de abordagem feitas por Cardoso. Por outro lado, aqueles(as) que discordam e criticam duramente a postura adotada pelo blogueiro tanto em seus 
posts quanto em sua participação nos ambientes digitais, parecem desejar encontrar algo que possa derrubar a credibilidade de Cardoso até mesmo para os(as) seguidores(as) do blogueiro.

Assumindo uma postura parcial, Cardoso pretende definir o seu público principal, que concorda com as ideias apresentadas. Entretanto, a fim de que a discussão não se resuma a manifestações de concordância e elogios, o blogueiro insere mecanismos que atraiam pessoas as quais não acessariam os blogs por que buscaram com base em interesses pessoais, mas redirecionados de sites de busca, tendo em vista que os posts abordam (e inserem) assuntos-chave que facilitam a localização. Com isso, gera-se o debate e Cardoso pode reforçar suas ideias, criando um ambiente propício a polêmicas e debates exaltados. Além disso, ao estabelecer essa parcialidade, Cardoso incorpora uma das diretrizes caras a blogs: adotar uma postura distanciada das mídias de massa, justamente por ser reflexo de opiniões, gostos e comportamentos daqueles(as) que escrevem os posts dos blogs.

Ter sempre razão emerge, nesse caso, como uma tentativa de revelar uma ideia ou uma opinião que seria a melhor para aquele contexto. Ou seja, inicialmente, a ideia contida no post apresenta, implicitamente ou não, uma opinião de Cardoso. Entre referências, piadas internas, sarcasmos ou ironias, é passada uma ideia principal que, no entender de Cardoso, seria a ideal e somente será compreendida por aqueles(as) que estão de acordo com ele e, ainda, são capazes de captar as sutilezas das referências embutidas nos posts.

Por outro lado, "ter sempre razão" seria uma forma de repelir as pessoas que acessam os blogs de Cardoso. Notamos, portanto, um paradoxo: deseja obter audiência, mas essa audiência deve entender as ideias e as propostas do blog. Porém, uma parte desse público discorda do conteúdo dos posts, acha que Cardoso é arrogante e egocêntrico e antiético. Ainda, existiria a opção, por parte do blogueiro, de bloquear os comentários contrários a sua posição, mas, ainda assim, ele publica. Essa atitude seria uma forma de mostrar quem é o dono do blog e que, aqueles(as) que são contrários(as) às ideias expostas devem procurar outros lugares. É uma forma de controlar os(as) detentores(as) de conhecimento nesses ambientes dos quais participa; Cardoso ocupa uma posição destacada no circuito-blogue e, portanto, seria aquele que detém o conhecimento responsável pela dinâmica dos blogs. 
Percebemos, portanto, que Cardoso assume uma postura de "conselheiro" ou, até mesmo, "esclarecedor" para aqueles(as) que ainda se encontram perdidos. Sua postura é a de expor seu ponto de vista como sendo o mais correto e o que melhoraria a vida de muitos(as) visitantes de seus blogs. Ao adotar esse posicionamento, Cardoso, obviamente, acaba por repelir comentaristas que discordam de suas opiniões, especialmente por tratar as considerações destes(as) de forma inferior e desqualificada.

$* * * * * *$

A noção de grupo dentro do circuito-Cardoso fica evidenciada a partir da observação de categorias de comentaristas, assim como de uma linguagem cara aos(às) participantes desses espaços interacionais. Notamos, a partir desse análise, que existe uma noção de grupo e, especialmente, a necessidade de exibir o seu pertencimento aos(às) demais participantes. Essa noção de pertencimento é bastante valorizada, principalmente quando o(a) comentarista em questão mostra estar próximo(a) de Cardoso. Essa proximidade é notada nos momentos em que comentaristas demonstram conhecer o blogueiro "off-line" e, ainda, nos instantes em que se concorda com Cardoso.

No último caso, essa concordância é identificada nas tentativas de interpretar corretamente piadas, sarcasmos, ironias e referências, demonstrando estar familiarizado(a) com as temáticas abordadas. Por conseguinte, essa postura determinaria um lugar privilegiado dentre os(as) comentaristas do Blog do Cardoso, do Contraditorium e do MeioBit. Por sua vez, esses comportamentos segregam iniciados(as) de "paraquedistas", ao buscarem "rotular" todos(as) comentaristas, especialmente aqueles(as) que discordam da postura de Cardoso.

Notamos que a exibição de um nível de conhecimento aceitável pela "corte de Cardoso" pressupõe a descrição minuciosa desses saberes e o compartilhamento destes deve estar relacionado às temáticas abordadas nos posts. Consequentemente, as argumentações, além de estarem alinhadas ao estilo de Cardoso, devem ser embasadas e sustentadas como se fossem parte de um experimento científico. Ou seja, todas as informações compartilhadas são passíveis de comprovações para que sejam aceitas e, ainda, devem refletir a persona digital do(a) comentarista e do próprio Cardoso. 


\subsection{Experiências e Estratégias: domínio das linguagens}

A popularidade de uma microcelebridade está diretamente ligada ao modo pelo qual o seu circuito-blogue é valorado, simbolicamente, por outras microcelebridades e, ainda, por seu público. As audiências, especialmente quando quantificadas, têm um peso relativamente grande na definição da visibilidade e da popularidade de um(a) blogueiro(a). O número de pessoas que visitam o Blog do Cardoso, o Contraditorium e o MeioBit parece ser um fator bastante considerado por Cardoso em sua tentativa de se tornar um "blogueiro profissional". Por essa razão, notamos a constante preocupação do blogueiro em aumentar o fluxo de visitantes para os blogs em análise.

O cuidado de Cardoso relaciona-se, principalmente, no bom uso de ferramentas disponibilizadas por empresas e sites de mecanismos de busca especialmente o Google. Por exemplo, o Google oferece o AdSense, ferramenta para realização de publicidade, por meio de banners, alocados em sites e blogs. Ainda, o sistema de pagerank do Google, no qual sites mais visitados e aqueles que contêm o maior número de palavras citadas pelo(a) usuário(a) no campo de busca figuram nas primeiras posições retornadas com a busca.

Essa última estratégia parece ser a mais usada por Cardoso, tendo em vista que, objetivamente, é esta que atrai mais visitantes. Assim, ao colocar no título alguma palavra relacionada, por exemplo, a uma notícia de grande repercussão, Cardoso aumenta as chances de aparecer nos primeiros resultados da busca, mesmo que a pessoa não esteja procurando por seu blog. Com essa tática, o blogueiro atrai pessoas de toda a sorte para seus blogs, muitos(as) dos(as) quais não se encontram familiarizados(as) com sua performance on-line.

Post 1: Exclusivo: As fotos do acidente do vôo 1907 da Gol de dentro do avião, publicado no Blog do Cardoso em 26/10/2006 - 1.106 comentários

Renato Marcel. 319 weeks ago

Interessante a chamada e o apelo, mas fico me perguntando se o resultado final é positivo.

Vale a pena movimentar tanta poeira em volta de um assunto tão delicado, como está sendo o acidente do avião da Gol, em troca de page views?[...]

Kobald 319 weeks ago

O que as pessoas não fazem por tráfego né???[...]

Roger Maffi Martin. 319 weeks ago 
[...]Exatamente, muitas pessoas simplesmente NÃO lêem tudo até o final. Muito bom esse post.

Reparei também em, no mínimo 5 detalhes que invalidam a veracidade das informações, hehehe.

Abraços![...]

Vinicius. 319 weeks ago

Parabéns Cardoso, como sempre chamando os leitores do Carloscardoso.com de Idiota.[...]

Christiano Milfont. 319 weeks ago

Pior que ainda matou o Paulo Muller... ele já ligou te exculhambando? :)

Aehuaehuaheuhuaehuahuehuaehuhuae

deixa para publicar as estatísticas após um mês... vai ficar milionário desse jeito![...]

Cristóvão 318 weeks ago

A bizarrice fica por conta de que:

a) o post falso foi criado para provar que a maioria não presta

atenção aos textos e vão logo concluíndo o que lhe desejam.

b) mesmo os comentários falando sobre a armação não são lidos e as pessoas comentam ainda acreditando na veracidade.

Conclusão: Não lêem o post, não lêem os comentários, e ainda comentam!

Por isso SPAM e phishing são tão bem sucedidos.

Post 2: Imagens exclusivas: terremoto no Haiti, publicado no Blog do Cardoso em 12/01/2010 - 213 comentários

Jailson Silva 151 weeks ago

Ri da pobreza alheia não ajuda nada, fazer esse tipo de humor caça desinformado é uma vergonha

Post claramente para trazer gente que tá procurando sobre a tragédia

Tudo por uns centavos do google[...]

Everaldo. 152 weeks ago

Isso tudo é o desespero por clicks? Criar um post despretensioso sobre um assunto atual e com a "pequena" chamada Imagens Exclusivas.

Como todos sabem, o "povo" adora uma desgraça, e falou que tem fotos, chove de acessos. [...] Mas também pudera, uma vez que a qualidade do blog despencou de "um dos melhores blogs do país" para "apenas mais um"...[...]

Gleidson. 151 weeks ago

Interessante que vários falam "desesperado por clicks" e devem chegar aqui pelo Google, procurando por "imagens dos desastres no Haiti".

Quem é pior? O piadista ou o falso moralista?

Post 3: Quem quer ver as fotos dos corpos do acidente da gol?, publicado no Contraditorium em 06/10/2006 - 826 comentários

Victor de G. 323 semanas atrás

Cardoso sabe pescar visitas. [...]

Maria. 321 semanas atrás

$<$ abbr title="" $><$ acronym title="'" $><$ blockquote cite="" $><$ code $>$ Ah achei chato seu post, mas tudo bem é sua opinião. $O$ mais curioso é que eu achei seu blog justamente fazendo uma pesquisa pra achar fotos das vítimas do avião da Gol, então você deveria agradecer a nossa sede de carnificina (já que eu mesmo descobri que não sou normal, né?) o q significa que seu blog foi lido pelo menos em partes por alguém anormal. $</$ code $><$ acronym $></$ abbr $>$

Post 4: Perdendo a fé na humanidade, publicado no Contraditorium em 07/08/2007 - 67 comentários

Victor Casablanca 285 semanas atrás

Prêmio DaVinci de paraquedista da semana?

Putz, agora é que eu oficialmente tenho medo de você, cardoso. Vai que falo alguma besteira e você me lança um mau-olhado... :D[...]

Gabriel Filho 279 semanas atrás

Comentário 3 em 1:

1) Eu achava que o Cardoso já tivesse perdido a fé na humanidade... 
2) Salsinhas podem ser consideradas "humanidade"?

3) Acho que já está na hora de cumprir essa previsão aqui: "Alguém aproveitará o fato de que $99 \%$ dos leitores mal lêem os títulos, e lançará o Primeiro Blog só de títulos, com o texto todo composto de "nononono". Ficará no ar 8 meses sem que ninguém perceba, mas mesmo desmascarado o faturamento do AdSense não será afetado."

Post 5: Brasil e Moçambique vão cooperar no desenvolvimento científico, publicado no MeioBit em 25/11/2008 - 396 comentários

leandrosnz $\bullet 4$ anos atrás

quando a noticia é sarcastia o Brasil (terra de muitas coisas) o topico fica absurdamente lotado, (topido de muitas coisas)...[...]

ritchie $\bullet 4$ anos atrás

Cara, realmente muito limitada essa sua visão ein...[...]

Seja mais coerente, o acordo é de desenvolvimento conjunto, e não de troca de conhecimento.

Cara... sério, deprimente esses argumentos, pueris e com cheiro de assinante da veja...não sei se vc é jornalista, mas devia realmente se manter apenas na área de tecnologia.

e se a idéia é chocar, sei la, criar polêmica, algo assim, cuidado, pq as vezes pode apenas parecer mediocridade

Freddy Liverpool $\rightarrow$ ritchie $\bullet 4$ anos atrás

Mas este é o objetivo principal, causar polemica.

Não sou o Jonny Walker, mas walk mais que ele...[...]

mauradog $\bullet 4$ anos atrás

O Cardoso faz isso de propósito! Tenho certeza!

Post 6: Linux atinge a marca histórica de 1\% do mercado, publicado no MeioBit em 02/05/2009 - 365 comentários

Moiséis Remo 4 anos atrás

Um post bastante polêmico com 49 assuntos diferentes nos comentários. Virou failblog isso.[...]

GuiSta $\rightarrow$ ywerosp $\bullet 4$ anos atrás

Lógico. Se vc quiser gerar polemica no Meiobit é só falar a palavra mágica : Linux.

Se disser que o Tux é feio e gordo vem pelo menos 120 comentários ;)[...]

Devido aos principais assuntos abordados em cada blog analisado, Cardoso possui um estilo peculiar de elaborar seus posts. Embora os temas caros à cultura geek estejam presentes em todos os blogs, a forma pela qual Cardoso aborda esses temas muda de um blog para outro. Por exemplo, o Blog do Cardoso apela para um estilo de humor "escrachado", com algumas nuances de sarcasmo. O Contraditorium aborda questões relacionadas ao mundo blogger, como, por exemplo: técnicas para aumentar audiências, experiências com o público, assuntos mais comentados ou virais da Web. Já a sua coluna no MeioBit conta com posts voltados para tecnologia e ciências.

Sob esta perspectiva, Cardoso gerencia performances e interações correspondentes ao estilo peculiar a cada blog em análise. Como problogger, o blogueiro deseja que seus posts alcancem uma audiência maior. Nesse sentido, Cardoso parece pensar em estratégias e articulações para que esse objetivo seja 
cumprido. Por essa razão, notamos, nos dados em análise, o cuidado em escolher um título "impactante" e, além disso, a inclusão de palavras-chave nos posts. Tal estratégia é construída com base nos algoritmos usados por sites de busca, como o Google, com o intuito de aparecer nas primeiras posições uma vez que alguém faça uma busca usando tais palavras. Isso fica evidenciado nos comentários que esclarecem as intenções do blogueiros nos posts em estudo.

Por conseguinte, notamos a existência de conjuntos de temas que costumam chamar atenção em cada um dos blogs em exame. Dentre os quais, podemos citar temas relacionados a questões religiosas; política; ostentação de saberes ligados a ciência e tecnologia, assim como a procedimentos relacionados a blogs e redes sociais; notícias de grande repercussão ou com potencial elevado de buscas.

A presença de paraquedistas ${ }^{31}$ acaba por revelar as técnicas usadas por Cardoso para aumentar o número de visitas para os blogs em questão. Os(as) comentaristas costumam questionar a atitude do blogueiro, enfatizando o quanto isso poderia se tornar prejudicial, já que os(as) paraquedistas, geralmente, não gostam do estilo dos blogs em análise. Além disso, tal performance acaba por ser classificada como antiética, tendo em vista de que não haveria a mobilização de um público interessado em acompanhar o blogueiros, mas de pessoas que não colaboram para o desenvolvimento de debates entre os(as) participantes desses espaços.

Apesar das críticas recebidas, Cardoso parece ter as suas estratégias legitimadas no instante em que os comentários ressaltam o uso de técnicas e artifícios para elevar o fluxo de visitantes. O destaque dado pelos(as) comentaristas às atitudes de Cardoso nos revela como as articulações podem ser construídas por Cardoso e seus(suas) seguidores(as) mais próximos(as) e aqueles(as) que encontram-se fora desse grupo. As técnicas empregadas por Cardoso atraem visitantes ocasionais, deslocados do contexto performáticos dos blogs em análise que, porém, interferem na popularidade e visibilidade destes espaços. Ainda que essas visitas representem pontos de vista diferentes, em relação aos de Cardoso e de sua corte, esses indivíduos fazem parte de uma

\footnotetext{
${ }^{31}$ Paraquedista é uma denominação dada pelos membros da corte de Cardoso quando se referem a indivíduos que passam a visitar os blogs em análise a partir de redirecionamentos feitos por sites de busca, como o Google.
} 
articulação cujo objetivo parece ser o de reforçar a própria visão de mundo do blogueiros e de seus(suas) seguidores(as).

O conhecimento e o uso de técnicas para aumentar a visibilidade legitima Cardoso como uma figura de destaque, pois o conhecimento dele acerca destes artifícios possibilitou a emergência do blogueiro como microcelebridade. Apesar de ser condenado publicamente, a popularidade dos blogs em análise acaba por legitimá-lo como alguém que conhece as linguagens e performances caras aos ambientes em que atua como microcelebridade.

A fama de Cardoso, segundo seus críticos(as), é questionável tendo em vista que não é fundamentada em habilidades caras a blogueiros(as), como, por exemplo, atrair visitantes com perfis semelhantes ao dele. Por essa razão, ao adotar um comportamento desse tipo, usando técnicas para aumentar o número de visitantes com base em sistemas desenvolvidos por sites de busca, Cardoso não poderia ser considerado um blogueiro profissional.

Por outro lado, ao assumir essa postura nos ambientes digitais em que atua, o blogueiro revela seus artifícios, apresentando-se de uma forma transparente diante de suas audiências. Mesmo assumindo uma atitude condenável, para seus(suas) seguidores(as) isso define conhecimentos e saberes relevantes para performances em ambientes digitais, assim como legitima suas habilidades que, por seu turno, são valorizadas por esse grupo.

\section{- $\quad$ Cardoso conduz Experiências}

Na seção "Quem Sou Eu” do Blog do Cardoso - e com links em outros blogs de sua autoria -, Cardoso manifesta o seu desejo de se tornar o "primeiro blogueiro profissional do Brasil" - problogger, como ele costuma denominar. No decorrer de suas tentativas, Cardoso faz questão de publicar algumas experiências e, sempre que possível, de comprovar os resultados obtidos por meio desses experimentos. A atitude do blogueiro não é bem-vista na blogosfera, tendo em vista que Cardoso manipula informações de seus blogs para que apareça, com mais frequência, nas primeiras linhas de sites de busca como o Google.

Em alguns momentos, Cardoso é criticado pelas pessoas que chegam até seus blogs, inclusive por alguns(mas) blogueiros(as). Ao admitir o uso de técnicas para aumentar o número de visitantes, Cardoso expõe o funcionamento dos 
bastidores e, dentro do grupo de blogueiros(as), isso pode ser encarado como uma atitude antiética.

Post 1: Exclusivo: As fotos do acidente do vôo 1907 da Gol de dentro do avião, publicado no Blog do Cardoso em 26/10/2006 - 1.106 comentários

\section{Cardoso. 318 weeks ago}

Gente, se vocês LEREM os comentários verão que a origem das imagens já foi desvendada no comentário de número 5, 4 se contar que o primeiro é um trackback do post onde EXPLICO TODA A HISTÓRIA. Post esse que é acessível pelo último link da matéria.

O que estou demonstrando, e vocês comprovam, é que NINGUÉM LÊ COMENTÁRIOS. Dos que lêem os textos, poucos conseguem um mínimo de pensamento crítico. [...]

Cardoso. 318 weeks ago

O recordista dos que não lêem NADA dos posts foi este aqui:

From: Fabiano <******@gmail.com>

Mensagem: Rapaz irresponsável!Não se brinca com uma tragédia como a que aconteceu ao boeing da GOL. Principalmente citando nomes, inclusive nome de uma autoridade federal o major da Aeronáutica que você citou. Cuidado com as brincadeiras, rapaz. Estou na tua cola!

Se deu ao trabalho de achar o "Fale Conosco" mas não leu sequer o texto, que dirá entender.

Fabiano, meu rei... o major Antonio Nelson é meu amigo, junto com o Rogério Healey, éramos inseparáveis, mas depois ele se envolveu com uma louraça e ficou pra lá de Bagdá.[...]

Hefesto. 318 weeks ago

Cara, decididamente o seu caráter é dos piores que existem pela internet. Com toda certeza. Como é que você pode ser uma pessoa assim tão sem dignidade, sem um pingo de respeito pela memória das vítimas desta terrível tragédia ? não importa que seja um adolescente ou mesmo maior de idade, você está dando provas não apenas de ser um irresponsável sem caráter algum, como também uma pessoa de má índole, uma pessoa perversa, decididamente. É uma pena que não existam leis neste país para punir esse tipo de deliqüencia. Que vergonha.

Cardoso. 318 weeks ago

Hefesto, você quer a lista das pessoas que chegaram aqui atrás das fotos, ou as justificativas que elas usam para pedi-las?

Sugiro que você modere seus adjetivos, senão ficará sem nenhum para usar com quem REALMENTE se delicia com fotos de cadáveres. Falar nisso, você não tem nenhuma foto dos Mamonas em seu computador, tem?[...]

Cobra 319 weeks ago

Caros imbecis que estão reclamando.

vim chutar o balde, fazendo apenas uma pergunta à vocês:

Vocês chegaram nesse post, nesse blog, via google com qual das frases:

a) "idiotas que usam tragédias para conseguir page views";

ou

b) "fotos acidente gol"

então, na boa, não encham meu saco e dos outros 287 leitores do feed de comentário do site do cardoso. valeu????

Post 2: Imagens exclusivas: terremoto no Haiti, publicado no Blog do Cardoso em 12/01/2010 - 215 comentários

Everaldo. 157 weeks ago

Isso tudo é o desespero por clicks? Criar um post despretensioso sobre um assunto atual e com a "pequena" chamada Imagens Exclusivas.[...]

Aliás, o mesmo se passou com o post no contraditorium falando sobre fotos da Autópsia da

Leila Lopes. Quantos acessos ganhaste com aquele post?[...]

Pablo. 157 weeks ago

Everaldo, 
Desespero por click ou não (e eu achei inteligente a sacada), é melhor do que ser idiota falso moralista que só se preocupa com um país, que já é dos mais fodidos, porque teve um terremoto. Ou que compara a morte da claudia leite, sendo que o próprio post explica a razão de ser (aposto que você não leu, um país inteiro de gente ferrada na vida, mesmo antes do terremoto.

Você, falso moralista, tão preocupado com a integridade do mundo, VÁ SALVAR AS BALEIAS, e pare de se preocupar com um blog que "despencou de "um dos melhores blogs do país" para "apenas mais um"...

Everaldo 157 weeks ago

Pablo, não sou falso moralista, nem critiquei o assunto do post.[...]Antes de criticar meu comentário, que expressa a MINHA OPINIÃO, leia bem e tente entender o que eu disse. O Cardoso não precisa de "Cavaleiros"...

Post 3: Quem quer ver as fotos dos corpos do acidente da gol?, publicado no Contraditorium em 06/10/2006 - 827 comentários

Kobald· 323 semanas atrás

Muitos visitantes graças a esse post não???[...]

Roberto martins. 323 semanas atrás

Depois do "efeito Cicarelli", mostre depois o efeito "vôo 1907".

Hoje mesmo recebi o e-mail das fotos com TO, CC, BCC completamente preenchidos com um monte de e-mails.[...]

Post 4: Eu não quero brincar então estou saindo do play, publicado no Contraditorium em 25/11/2008

Janaína Amado $\cdot 216$ semanas atrás

Quer que eu dê a mãozinha e diga que isso é assim mesmo?

depois que ja ganhou seu prestigio resolveu dar um chute ao invés de sugerir a mudança do sistema?? não precisa mais né?[...]

Assim passa a falsa impressão que uma pessoa que fez um blog falando sobre tecnologia há uns 4 meses jamais poderá igualar-se ao meio bit, pura besteira.[...]

Igor 216 semanas atrás

Janaína,

Quem disse que ter um blog é tarefa fácil?

Se quiser ter um blog de tecnologia que se compare ao Meio Bit, faça sua parte! Vista a camisa e TRABALHE!

Cardoso 216 semanas atrás

Curioso. No tempo de vida do MeioBit surgiram vários blogs do nada, como o Digital Drops, que hoje é considerado um "dos grandes", mas nenhum desses chegou onde chegou fazendo mimimi.

Se você quer chegar ao MeioBit fazendo trapaça de links, não vai chegar mesmo.

De resto, curioso promover conteúdo tentando usurpar o lugar de quem está lá justamente por TER conteúdo.

Doni 216 semanas atrás

[...] Janaína, essa era já existiu, e muito tempo antes dos dias atuais[...] O "grande" no caso não está clamando pela manutenção de um status quo, mas de punição séria para uma trapaça infantil. $O$ "pequeno" que reclama um lugar num ranking como esse, não importa o preço, está mostrando o quanto se sente inferior, em termos de ego mesmo, e incapaz de criar conteúdo de qualidade.

Nick. 216 semanas atrás

Pois é, só se chega em algum lugar com muito trabalho sério e dedicação. Se o Digital Drops é considerado um dos grandes blogs de tecnologia do Brasil, eu também tenho outros blogs pequenos que estão começando, mas nunca pedi links, fiz memes de troca de links ou nada do gênero.

Se você discorda e quer fazer algo artificial para passar o Edney no BlogBlogs? Pode fazer, mas eu aviso, a longo prazo isto não dá certo, porque não atrai visitantes, não fideliza leitores, não atrai anunciantes, não traz relevância, não acrescenta conteúdo, enfim, não adianta nada. Se você fizer da forma certa, como o atual líder do ranking que escreveu um widget do BlogBlogs para o blogger, neste caso eu acho totalmente válido. Através de correntes de links, sou contra. 
Todos estes memes de links são rídiculos e sem sentido, seja o emoday, contagem de números ou whatever. Eu prefiro não aparecer em nenhum ranking do que submeter meus leitores e assinantes de feed a isto. Os únicos memes que participei tinham propósito e eram muito mais interessantes, mas isto foi só no começo. $E$ antes que alguém venha dizer que o meu blog só por ser grande não é atualizado, é só visitar e conferir. Eu escrevo várias vezes ao dia, e sempre com muita seriedade.

Agora vamos trabalhar.

SillyQ 216 semanas atrás

Caríssima Janaína e outros,

Moro fora dessa terra linda que é o Brasil há bastante tempo e vou te falar sobre uma coisa que parece boba mas é regra em qualquer lugar. Há regras sim, e todo mundo respeita. Uma qualidade muito apreciada chamada CREDIBILIDADE só se conquista através de CONSISTÊNCIA. Ser brilhante é muito bom, mas ser brilhante por alguns momentos é como ter uma daquelas bandinhas efêmeras que só lançam um hit. Acho que é disso que se fala quando se menciona a palavra TRABALHO.

Isso não é mimimi. Não sou blogueiro mas assim como muitos outros brasileiros exilados, fontes confiáveis (e muitas vezes bem humoradas) sobre a nossa pátria mãe querida, sobre o comportamento, seja ele do mercado tecnológico ou "fofial" como preferem alguns, são os bons Blogs. Quando chegamos ao ponto de recomendar, seja na comunidade acadêmica ou business, um blog como fonte de informação ou risadas é porque ele produz esse tipo de material de forma consistente ao longo do tempo.

Funciona assim no emprego, nas ciências, em qualquer setor. Resultados, conhece?

Essa coisa de estrelismo súbito e entusiasmo por algo sem estofo ou histórico é o reflexo perfeito do que vemos na inconsequiência de atos de muitos governantes por aí. Há pleno espaço para o talento, desde que regras básicas (ÉTICA) sejam seguidas. Pior pra cada um de vcs que acha "que pode" quebrando regras. Há referências negativas também e elas se solidificam tanto quanto as boas. Uma recomendação de um medíocre é garantia de mediocridade e desrespeito.

Boa Sorte, pensem mais antes de agir.

$\mathrm{KBN}$,

Post 5: Haiti - terra amaldiçoada por Deus, publicado no Contraditorium em 13/01/2010 - 133 comentários

Ontem fiz um post no CarlosCardoso.com sobre o Haiti. Rendeu um esporro do Dudu Tomaselli, muito bem-dado (sobre SEO, calma) e um monte de gente me xingando e ameaçando minha família, diante de tanta insensibilidade diante de um momento de dor. Compreendo, afinal nada mais justo do que se revoltarem contra meu desprezo à sua preocupação com um lugar que dois dias antes nem sabiam que existia.[...]

Eu sei, eu dou murro em ponta de faca, achar que a maioria iria perceber a crítica social, como fez o Bobagento, era querer demais. Só que o mais irritante é que enquanto críticas disfarçadas de piadas, ou mesmo piadas legítimas como quando disse que o Michael J. Fox estava em Porto Príncipe mas "não sentiu nada" são atacadas com uma fúria insana, quase atribuindo aos humorista a culpa pelo acidente, outros passam impunes.

Na cabeça de um monte de gente que me xinga Pat Robertson no máximo "se equivocou", afinal é um "homem de Deus", um "Cristão", e não deve ser levado ao pé da letra.

Sinceramente eu prefiro viver em um mundo cheio de FDPs como eu que fazem piadas impróprias, do que em um mundo onde Líderes Religiosos Respeitados como Pat Robertson falam sério.

Infelizmente não posso escolher.

Post 6: Linux atinge a marca histórica de $1 \%$ do mercado publicado no MeioBit em 02/05/2009 - 365 comentários

ywerosp $\bullet 4$ anos atrás

[...]Acho fantástico como um post sobre Linux tem tanto comentário (de 13:32 até 21:20 183 comments) enquanto um sobre o Windows Seven ou Vista (04:45 de 01/05 até agora 40 comments)...[...]

Pryderi $\rightarrow$ ywerosp $\bullet 4$ anos atrás

[...]Isso se deu pela quantidade de trolls, tards e salsas que apareceram e as subsequentes respostas e sarcasmos inerentes.[...] 
GuiSta $\rightarrow$ ywerosp $\bullet 4$ anos atrás

Lógico. Se vc quiser gerar polemica no Meiobit é só falar a palavra mágica : Linux.

Se disser que o Tux é feio e gordo vem pelo menos 120 comentários ;)[...]

Post 7: Engadget declara guerra aos trolls, publicado no MeioBit em 02/02/2010 303 comentários

tatakoto_BR ->・ 3 anos atrás

Assuntos polêmicos atraem trolls além de usuários mais bem comportados, e audiência é lucro não?

Tbm é complicado diferenciar uma opinião mais acalorada de uma trollagem.

Carlos Cardoso $\rightarrow$ tatakoto_BR $\bullet 3$ anos atrás

Grande engano. A maioria dos usuários detesta trolls. Não acha graça em gente perdendo tempo com brigas. Me mostre UM SITE que seja respeitado e esteja lotado de trolls

Cardoso costuma realizar experiências com o objetivo de comprovar suas teorias acerca da "arte de blogar". Alguns de seus posts possuem um "post irmão" que serve para explicar e comprovar o experimento realizado. Em outras ocasiões, o próprio post reúne experiências esclarecidas pelo blogueiro e evidenciadas por seus(suas) comentaristas.

A condução de experiências costuma surgir a partir de acontecimentos de grande repercussão, em que Cardoso se aproveita do elevado volume de buscas de palavras-chave em sites especializados em busca, como o Google e o Bing. Além disso, dependendo da temática do blog, Cardoso aborda temas que costumam render discussões, expondo uma opinião parcial e, quase sempre, apelando para referências, sarcasmos e ironias que confundem as audiências, rendendo, por conseguinte, diversos comentários.

Esses experimentos são aplicados e, posteriormente, explicados por meio de "provas" observadas na própria seção de comentários. Como o comentário é uma performance bastante valorizada na blogosfera, Cardoso conduz essas experiências como forma de provar que, por meio destas, é possível atrair diversos(as) comentaristas e incitar uma discussão/debate entre esses indivíduos.

As experiências são relatadas por meio dos retornos obtidos e demonstrados pelo próprio blogueiro. Uma vez que seu desejo é o de ser tornar um "problogger", ou seja, um "blogueiro profissional", Cardoso não mede asconsequências para alcançar o seu objetivo e o de mostrar, perante a sua audiência, que ele detém o conhecimento técnico e prático para o intento.

As estratégias primam por explorar sistemas de buscas, com ênfase em palavras-chave, temas e títulos que abordem, de alguma forma, um assunto 
considerado relevante. Para os comentários observados, notamos que a relevância do assunto passa pelos seguintes pontos: notícias de grande repercussão; assuntos considerados polêmicos (discriminações étnicas, sociais e de gênero); opção por determinados softwares, etc. Ao colocar alguma palavra que explicite o assunto ou a notícia em questão, Cardoso destaca o post para os sites de busca, como o Google e Bing, no instante em que alguém digita algumas das palavras contidas nos posts em questão. Cabe ressaltar que as primeiras posições em sites de busca também consideram as citações e referências feitas em outros websites e blogs. Ao abordar assuntos polêmicos, Cardoso aumenta, potencialmente, as chances de outras microcelebridades comentarem sua performance e, com isso, citarem seus posts.

Esse tipo de tática é considerada por muitos(as) blogueiros(as) como algo antiético na blogosfera, tendo em vista que não seria possível atingir os objetivos de um blog atraindo públicos que não estejam interessados em acompanhar as produções publicadas nesses espaços. Nesse instante, Cardoso se aproveita dessa situação para, assim, gerar o debate e a discussão entre diversos pontos de vista. Porém, como podemos notar, o debate acaba por reforçar, em muitos casos, a defesa de pontos de vista de lados opostos sem o diálogo supostamente almejado pelo blogueiro.

Em diversos momentos, Cardoso ressalta a importância de debates serem realizados nas seções de comentários. Isso, segundo o blogueiro, enriqueceria as performances e colocaria seus blogs em outro patamar, se assemelhando, por conseguinte, a um fórum de discussão. Assim como em outros blogs, os blogs em análise costumam contar com comentários elogiosos e críticos. Porém, para Cardoso o elogio ou a crítica por si só não renovam ou propiciam a troca entre os(as) comentaristas. Por outro lado, ao abordar assuntos considerados polêmicos, o blogueiros traria diferentes perspectivas e estimularia os debates entre os(as).

As experiências conduzidas por Cardoso pretendem revelar, ainda, as performances dos(as) visitantes quando acessam os posts. Os experimentos visam estabelecer a existência de padrões performáticos que podem ser observados na blogosfera. Segundo o blogueiro, a maioria das pessoas não lê o post por inteiro, atentando-se somente para seu título ou para suas primeiras linhas. Assim, quando alguém faz um comentário que contraria o blogueiro e não apresenta argumentos 
capazes de sustentá-lo, Cardoso adota uma performance arrogante e acaba por insultar esses indivíduos.

Nos blogs em que Cardoso participa, tudo parece ser pensado para atrair audiências e, ainda, para estimular a participação das mesmas. Tendo em vista que os comentários são a parte quantificável e visível, em termos de medir a popularidade, torna-se primordial estimular a participação do público.

Primeiramente, a atração de público para o blog é um mecanismo que requer habilidades e pode culminar ou não no surgimento de um circuito-blogue com visibilidade. Nesse sentido, cativar pessoas interessadas em ler e visitar com frequência o blog é algo dotado de relativa complexidade. Em segundo lugar, fazer com que esse público comente acaba por se revelar uma tarefa árdua, especialmente se não existem comentários prévios. Em terceiro lugar, estimular um debate que renda, por conseguinte, diversos comentários e o retorno de visitantes, é uma tarefa muito mais difícil. Por essa razão, o que observamos nas performances de Cardoso é o interesse de usar grande parte dos recursos da Web que possam tornar seus blogs mais visitados e mais comentados. Ao buscar conhecer essas ferramentas, Cardoso parece descobrir um caminho para tornar seus blogs populares, assim como para estabelecer uma persona digital que, polêmica ou não, atraia indivíduos dispostos a comentar.

\section{- $\quad$ Exclusividade e Rapidez}

Como nas mídias de massa, a exclusividade e a rapidez com que um(a) blogueiro(a) publica e discorre sobre uma notícia podem colaborar para a composição de sua visibilidade em ambientes digitais. Sabemos que este fator deve estar relacionado a uma série de questões as quais contribuem para a popularidade de um(a) blogueiro(a), como acontece no circuito-Cardoso. Constantemente, o blogueiro tenta oferecer exclusividade e rapidez nos posts que publica. Essa seria uma forma de obter credibilidade, assim como elevam as chances de Cardoso ser citado em mídias de massa e por outras microcelebridades. Uma vez que se consiga esse reconhecimento (mídias de massa + microcelebridades), seu circuito-blogue conquista valor simbólico e, por conseguinte, ganha visibilidade. 
Notamos, mais uma vez, o aproveitamento, por Cardoso, de técnicas ligadas a sites de busca para atrair visitantes para seus blogs.

Post1: O acidente da TAM e o Marketing do Avestruz, publicado no Blog do Cardoso em 17/07/2007 - 92 comentários

Mauro Margarida· 287 weeks ago

Cardoso, rápido como sempre.

Um comentário: Cheguei em casa e achei que ia ter meus feeds inundados de posts sobre isso. Acho que os blogueiros estão dormindo, tomando cerveja ou chocados. Dos que eu acompanho, somente você, o Doufer e o VA noticiaram. Mais alguém que eu não conheço?[...]

Daniel 287 weeks ago

Cardoso, acabei de ler seu post, e to assistindo a Band, nesse momento, 23:47.

Agora a pouco (uns 10 minutos) eles falaram que a TAM não divulgou a lista dos mortos ainda, pois pela lei, só podem divulgar essa lista após as famílias serem avisadas.

As consequências do acidente da GOL ainda estão rolando até hoje, e estão colocando a culpa nos controladores de vôo (que podem até ter culpa, mas o maior culpado, é quem deixou pessoal incapacitado lá) Agora, sobre o acidente da TAM, quem vão culpar?

Post 2: Responda rápido: Isso aconteceria na Suécia?, publicado no Blog do Cardoso em 27/1 1/2008 - 99 comentários

Tebald. 216 weeks ago

[...]Enquanto pessoas estão sem suas casas, sem roupas para vestir e sem comida e sem noticias de seus familiares, vem um blogueiro que não sabe mais o que falar e resolve criar caso em cima das ações de desabrigados e vitimas de tragédias. Ai vem os seguidores de São Cardoso e resolvem também que "aquele povinho brasileiro de SC não merece nossa ajuda, ao invés de ajudar vamos criticar, vamos botar lenha na fogueira".

Esse tipo de comentário preconceituoso desmotiva as ações de ajuda, e aquelas pessoas realmente precisam de ajuda, inclusive o cara que está roubando a cerveja!

Abra a cabeça senhor Cardoso e dê uma olhada no mundo a sua volta, onde um post desses pode lhe render alguns trocados e uns elogios dos seus puxa-sacos, mas no mundo real, pode ocasionar apenas que alguém necessitado deixe de receber um punhado de comida ou um agasalho.

Cardoso 216 weeks ago

O cara que está roubando a cerveja é um coitadinho?

É por isso que o Brasil está na merda que está, por causa dessa mentalidade do coitadinho.

Tebald. 216 weeks ago

O Brasil está do jeito que está (ou do jeito que você acha que está) porque tem muita gente dando opinião sobre o que é o certo a se fazer e muita pouca gente fazendo o que é certo.

Cardoso. 216 weeks ago

É, o Brasil está maravilhoso, eu que estou errado.

Spock. 216 weeks ago

Realmente,VOCÊ está errado...está tudo ótimo!

Não acredita? Assista no Jornal Nacional!

Aliás,se um pai de familia de 45 anos,estudado,com um monte de línguas no curriculum não arruma emprego,a culpa é DELE por não ser qualificado,pois emprego tem,

Fonte: Jornal da Globo.

Leonardo 215 weeks ago

hahahaha

realmente, spock ... espero que um dia vc veja esse brasil maravilhoso do qual fala e seja o pai de 45 anos estudado e com " $\mathrm{N}$ " linguas no currículo que não arruma emprego ... no olho dos outros é coca-cola né?

Séfora 215 weeks ago

"mas no mundo real, pode ocasionar apenas que alguém necessitado deixe de receber um punhado de comida ou um agasalho."

Olha pelo que eu já vi no "mundo real" a maior parte dessas doações vai parar no lixo .É claro que tem muita gente que precisa realmente, mas acho graça nessa falsa solidariedade 
do povo....acredito que pouca gente tem mesmo interesse em ajudar realmente.Infelizmente o povo gosta muito da desgraça alheia isso sim.

Post 3: Deixem o Arcebispo de Recife em paz!, publicado no Contraditorium em 2009 - 230 comentários

William Latencio 202 semanas atrás

Interessante o seu ponto de vista. Parabéns por aprofundar a discussão.[...]

Atalaia 201 semanas atrás

Sabe que foi o melhor texto sobre o assunto que eu li até agora ? Me fez até pensar sobre o que eu escrevi ...

No fundo, o cara realmente é fiel aos seus princípios. O problema é que os princípios dele é que são desumanos demais .......]

Lucas Charriot. 201 semanas atrás

Muito bem escrito Cardoso,

O engraçado nesse caso é que ele foi "construído" pela mídia de massa, enfim, para nada mais do que causar polêmica. Explico: no código penal o aborto é possível se há perigo à vida da mãe (art. 128, I, do CP) e isso acontece a toda hora sem qualquer reclamação de ninguém. Claro, mas isso não daria uma boa reportagem, então, ao outro fundamento para o aborto, ser derivado de estupro (art. 128, II, do CP), foi dada atenção máxima, criando todo esse frisson.[...]

Post 4: Um guri de sorte com 13 anos e câncer no fígado, publicado no Contraditorium em 03/05/2010 - 145 comentários

meire isabel. 141 semanas atrás

Vc está certo, como quase sempre, mas esqueceu a realidade com que convivem os jogadores do Santos. [...]Numa entrevista da semana passada, o pai do Neymar esteve contando algumas coisas sobre a vida deles. São evangélicos e pagam o dízimo para a igreja, 15 paus todos os meses, frequentam os cultos, levam a religião a sério.[...]

Shrimp. 141 semanas atrás

Tudo certo.

Mas não entendi pq juntou uma história bonita dessas com o lamentável caso do Santos, no mesmo post.

Fazendo essa comparação é óbvio q esta incitando o repúdio aos jogadores. Basicamente você está "explicando a piada" pra quem lê, coisa q todos sabemos não ser seu estilo.

Podia fazer o post e deixar para o leitor decidir o q é certo ou errado.

Abraço.

Cardoso 141 semanas atrás

Eu me reservo o direito de expor a minha opinião, obrigado.[...]

Vilma. 141 semanas atrás

[...]Belo post, digno de muitos replys !! Os rapazes do ocorrido nos EUA mereciam uma estátua!

Abraços fraternos!

Post 6: Blue \& Me - Punto pra Microsoft, publicado no MeioBit em 05/10/2007 68 comentários

bruno $\cdot 5$ anos atrás

Caras, parabéns pelo convite da Fiat.

A matéria está ótima :)

É o MB ampliando horizontes!

quedaderider $\bullet 5$ anos atrás

Eu ja tinha lido sobre isso a uns meses mas ainda nao tive a chance de testar.

Vcs conseguiram me responder muitas duvidas!

Obrigado!

Agora eh so esperar pra sair em outros modelos de carro, pq 40mil é muito caro prum carro![...] 
Cardoso posiciona-se como um detentor de saberes considerados exclusivos, para o contexto de seu circuito-blogue. Essa postura é usada constantemente pelo blogueiro tanto como uma forma de aumentar visibilidade quanto um artifício para manter-se como uma figura de destaque. Na tentativa de conduzir suas experiências, Cardoso reúne vários conjuntos de palavras com a intenção clara de aparecer nas primeiras posições de páginas de sites de busca. Por outro lado, a exclusividade de saberes também o legitima como o personagem de maior visibilidade no circuito-Cardoso. Ou seja, por ser alguém importante naquele âmbito, Cardoso gerencia performances e interações, seja contribuindo com a publicação de posts ou, ainda, com a menção de notícias de grande repercussão. Nesse último caso, a sua postura é quase sempre questionada pelo fato de que o blogueiro usa essa oportunidade para elevar o valor simbólico para os blogs em análise.

No momento em que publica posts cujos assuntos são relacionados a notícias de grande repercussão, alguns fatores são levados em conta por Cardoso: quanto tempo levou para a notícia ser difundida; o material à disposição do blogueiro; o teor e o consequente impacto nas audiências; o bom uso de ferramentas Web (como os sites de busca, por exemplo) para atrair visitantes. Com base nisso, Cardoso elabora seus posts, visando atingir algumas categorias de público: se a apuração da notícia e a reunião de material foram rápidos, o post busca os(as) membros(as) de sua corte, assim como aqueles(as) que gostam de seus blogs; se outros(as) blogueiros(as), com um posicionamento semelhante ao de Cardoso, já publicaram posts elaborados e completos, ele aproveita para fazer suas ironias, sarcasmos e piadas, além de usar as técnicas para atrair visitantes de toda sorte.

A exclusividade tem um peso relativamente grande na blogosfera. Por exemplo, quando Cardoso é convidado para o evento da Fiat, seus(suas) visitantes criam expectativas e visitam constantemente os blogs em exame para verificar se estes foram atualizados. A questão da novidade é algo valorizado assim como o acesso a algo considerado exclusivo. Isso coloca Cardoso em um patamar destacado, justamente por ter sido reconhecido como uma "voz" para escrever sobre algum evento ou algum produto. Por conseguinte, por ser uma microcelebridade e estar relativamente mais próximo de suas audiências, a opinião 
de Cardoso é apreciada sob a luz de alguém que, supostamente, não foi influenciado por nenhuma marca ou mídias de massa.

Nesse sentido, a elaboração de um material novo e exclusivo parece valorizar o circuito-Cardoso. Tais performances, com o tempo, dão credibilidade ao blogueiro e costumam atrair pessoas que se interessam pelos posts de Cardoso. Ao tentar ocupar uma posição de destaque, percebemos o interesse de Cardoso de publicar posts que apelem para aumentar o volume de visitas. Como estas são compostas pelo público usual e por aqueles(as) "pescados" nos sites de busca, o blogueiro elabora estratégias capazes de elevar a quantidade de visitantes ao mesmo tempo em que tenta promover um suposto debate entre os dois lados.

Por ser constituída de milhares de blogs, a blogosfera conta com ambientes digitais semelhantes e, ainda, com blogueiros(as) ansiosos(as) por conquistarem leitores(as) para seus posts. Nesse sentido, notamos duas características importantes quanto à performance de Cardoso nesta categoria de análise. A primeira está relacionada à própria cultura geek, no que diz respeito a "desbravar" saberes e a ostentá-los dentro do grupo como forma de assumir uma posição de destaque. Percebemos isso quando Cardoso pretende mostrar outras perspectivas sobre determinados assuntos, assumindo uma postura de superioridade por ter feito uma interpretação que vai de encontro a que seria difundida, por exemplo, pelas mídias de massa.

Em segundo lugar, observamos elementos ligados às próprias mídias de massa como forma de legitimação e de composição de credibilidade. Ao elaborar algo exclusivo ou dar uma notícia em primeira mão, Cardoso pavimenta-se como uma referência, ainda que os assuntos não fiquem presos ao universo da cultura geek. Nesse sentido, podemos dizer que o próprio reconhecimento das mídias de massa, de empresas ou de agências de publicidade também é considerado importante pela microcelebridade em questão e, principalmente, por seu público.

Ao combinar essas duas características, podemos dizer que Cardoso parece conhecer bem o seu papel no circuito-Cardoso e, especialmente, o papel de seus(suas) comentaristas na legitimação dessa posição. A legitimidade dada pelos(as) comentaristas é proveniente de uma troca estabelecida entre blogueiro e público. Cardoso faz uso de artifícios para atrair um público heterogêneo, o que lhe dá, ao mesmo tempo, popularidade e visibilidade. Tais artifícios funcionam como um convite ou, ainda, uma degustação para o que será encontrado nos 
ambientes em análise. Por conseguinte, seus posts se encarregam de oferecer informações as quais serão interpretadas de diversas formas por esse público. Por fim, aqueles(as) que se interessam, passam a acompanhar as produções do blogueiro e passam a referenciar seus blogs como portadores de exclusividade e ineditismo.

\section{- Moderadores(as) e Como comentar nos Blogs de Cardoso}

Nas seções de comentários do Blog do Cardoso, do Contraditorium e do MeioBit, costumam acontecer debates entre os(as) comentaristas sobre os temas abordados nos posts. Em algumas ocasiões, os debates acabavam por se distanciar do assunto principal e as discussões entravam em outros méritos que não haviam sequer sido mencionados nos posts criados por Cardoso. Quando isso acontece, entram em cena os(as) moderadores(as) cuja função é a de manter o debate focado nos assuntos abordados nos posts e as regras de comportamento nas seções de comentários dos blogs analisados.

Nesse sentido, os(as) membros(as) da "corte de Cardoso" parecem assumir diversas funções: política, ao dar legitimidade ao que o blogueiro publica; estratégica, ao formar um público com relativo poder simbólico e de persuasão; e, ainda, o de conduzir os debates que ocorrem nas seções de comentários.

Cabe à "corte de Cardoso" moderar e guiar os(as) comentaristas, mostrando: como um post deveria ser interpretado; quais os princípios norteadores da performance de Cardoso; como agir dentro de um debate iniciado nas seções de comentários em análise. Ou seja, uma vez que exista fuga ao(s) tema(s) principal (is), cabe aos(às) moderadores(as) a tarefa de fazer essa recondução.

Post 1: Ou dá ou desce, Bispo Macedo, publicado no Blog do Cardoso em 01/12/2005 - 1.181 comentários

B.L.E.F(Comentario P. 322 weeks ago

[...]Quanto ao Video mas uma vez eu digo, ele eh falso, procure so se informar, a 10 anos em cima desse video e de falsas acusacoes feitas pelo ministerio publico(num eh segredo para ninguem que a Globo manda no pais) se abriu um inquerito contra a Iurd ,porem agora 10 anos depois esse processo foi Fechado por falta de provas e, Principalmente por Tal video ser uma montagem feita por um ex pastor, em parceria com a globo, que foi expulso por se envolver em orgias e praticas condenadas pela palavra de Deus.

[...]Obrigado pela atencao e que Deus Abencoe a todos.

(Cobra) Capeta. 322 weeks ago

Cara, tu é chato hein?

solucione o seu problema de não ter o que fazer em 5 passos.

faz o seguinte:

1. entra no http://registro.br 
2. registra o domínio www.euamoaiurd.souburro.com.br

3. Monta um site. Se precisar de webconstrutor fale com meu amigo Carlos.

4. cria um link para esse site aqui

5. deixe explícito que os comentários de gente chata não são bem vindos aqui e devem ser feitos

lá.

e que o demônio lhe acompanhe.[...]

Post 2: Imagens exclusivas: terremoto no Haiti, publicado no Blog do Cardoso em 12/01/2010 - 215 comentários

Filho 152 weeks ago

Essa brincadeira é no mínimo idiota. Não importa se o país é fudido ou não, devemos respeitar esse momento,

PS.. Eu ajudo a salvar as baleias, sou filiado ao greenpeace[...]

Elize 151 weeks ago

Cara vc pode salvar quantas baleias quiser mais pode saber que tudo vai acabar na mesma merda. Copenhagen decidiu nosso futuro, ninguem vai fazer porra nenhuma, no final vai ser cada um tentando salvar a própria bunda e tenho certeza que as baleias não vão ser mais importantes quando vc estiver fugindo de um terremoto, tsunami, furacão, do inferno etc. Só nos resta rir, então se quer encher o saco de quem faz húmor vai procurar outro blog.

Post 3:Atendendo a pedidos - mais ou menos, publicado no Contraditorium em 03/12/2008 - 104 comentários

Ivan. 209 semanas atrás

Uma previsão me vem à mente nesse momento......Vão chamar o Cardoso de burro por dizer que Foca é peixe.....

Ahh e mais uma coisa, parafraseando Heath Ledger:

HАНАНАНАНАНАНАНА[...]

[bigode] 209 semanas atrás

Sabe, não é querendo ser chato (mentira), mas eu odeio esse tipo de comentário. Só estraga a página. $[\ldots]$

Janaína Amado. 209 semanas atrás

Voce está precisando de um regime :)

ps: Antes que falem que nao tratei do assunto, a imagem é parte do post.

Post 5: Linux atinge a marca histórica de $1 \%$ do mercado, publicado no MeioBit em 02/05/2009 - 365 comentários

Indefinido $\bullet 4$ anos atrás

voce esqueçeu de completar tard feliz porque eu aproveito reamente tudo da internet :) (agora voce so fica nessa vidinha de chamar os outros de tard e nao aproveita nada)[...]

Gaviao_molhado $\rightarrow$ Indefinido $\bullet 4$ anos atrás

[...]Esse cara além de Troll e Tard ainda é Salsa, acho que temos um novo recorde aqui.

PS: O Windows Seven provavelmente será o melhor Windows já feito até o momento, mas se ele fosse perfeito a Microsoft fecharia as portas rapidamente, já que ninguém compraria uma versão posterior do windows.[...]

Pryderi $\rightarrow$ Juliano-Buettner $\bullet 4$ anos atrás

Ao que eu vi, sim. Já já o Max Laguna aparece aqui colocando um link mostrando se um outro ganhou antes ou não.[...]

Alan Menzy $\rightarrow$ Pryderi $\bullet 4$ anos atrás

Cadê o Síndico?

se marcar, acho que foi ele que fez "isso aqui": http://www.youtube.com/watch?v... [...]

Juliano-Buettner $\rightarrow$ Indefinido $\bullet 4$ anos atrás

É que não tenho nada pra fazer, anão ser twittar ou ler blogs e este post está cheio de tards. [...]

Alan Menzy $\rightarrow$ Indefinido $\bullet 4$ anos atrás

Isso, continue assim, para a nossa alegria!

Tem muito carinha aqui que mal saiu das espinhas e acha que abafa...

Ta ficando insuportavel pessoas que não respeitam opiniões das outras![...] 
Os(as) moderadores(as) das seções de comentários do Blog do Cardoso, do Contraditorium e do MeioBit parecem assumir uma posição legitimada pelo próprio Cardoso, tendo em vista que o papel desempenhado, de certa forma, interfere nas diretrizes adotadas pelo blogueiro nos blogs analisados. Essas pessoas parecem atuar de forma a manter a integridade das seções de comentários. São comentaristas que, por fazerem parte da "corte de Cardoso", parecem identificar o que agrada Cardoso e incorporam essas referências em suas performances. Esses indivíduos coordenam esses espaços, tendo em vista que, por ser uma figura destacada do grupo, Cardoso nem sempre pode assumir a tarefa de manter a ordem nesses ambientes.

Em um primeiro momento, parecem ser pessoas conciliadoras, buscando manter o fluxo dos debates e, sempre que possível, conservar as discussões no âmbito dos assuntos tratados nos respectivos posts. Porém, por serem seguidores(as) de Cardoso, adotam práticas semelhantes as do blogueiro. Por conseguinte, sempre estão defendendo os pontos de vista de Cardoso.

O comportamento desses indivíduos acaba por se revelar extremamente estratégico, afinal a performance e a persona digital de Cardoso são legitimados, também, por meio da atuação dos(as) moderadores(as). Uma vez que essas pessoas digam o que se deve fazer, como se deve comentar, como se comportar e quais pontos de vista são defendidos, a fama e a visibilidade de Cardoso são ampliadas e o circuito-Cardoso tem sua legitimidade reforçada. A "voz" de Cardoso encontra ressonância, tendo em vista que são postas em prática no âmbito das seções de comentários em análise.

Esses moderadores(as) assumem posições estratégicas dentro do grupo. De certa forma, são credenciados(as) por Cardoso para ocuparem esse papel, tendo em vista que não são reprimidos(as) pelo blogueiro. Portanto, uma vez que o(a) moderador(a) interfira no debate, seu nome é trazido aos holofotes e, por conseguinte, começa também a conquistar o seu espaço e visibilidade.

Para o grupo, os(as) moderadores(as) ocupam uma posição privilegiada pois têm um nível de conhecimento equiparável ao de Cardoso. Alguns(mas) destes(as) chegaram a conhecer o blogueiro pessoalmente, acompanhando os eventos dos quais Cardoso participa. Por essa razão, mesmo sem serem microcelebridades, 
esses(as) comentaristas tornaram-se famosos(as) por comporem a "corte de Cardoso" e, ainda, atuarem como moderadores(as) do circuito-Cardoso.

$* * * * * *$

O conhecimento é algo bastante valorizado no circuito-Cardoso, pois pressupõe um bom uso dos recursos existentes em ambientes digitais, especialmente no âmbito dos blogs. Cardoso parece lidar naturalmente com esses recursos, conhecendo suas possibilidades e limitações, transformando-os em plataforma para as performances e as interações de sua persona digital.

Cardoso incorpora uma "fala" profissional, no que diz respeito às performances e interações realizadas no Blog do Cardoso, no Contraditorium e no MeioBit. Seu papel condiz ao de alguém com amplo conhecimento nessa área de atuação e que, por isso, não poderia ser questionado. Por essa razão, alguns de seus posts são tratados como experiências, a fim de que o blogueiro identifique o comportamento de seu público ao ser exposto a determinadas abordagens e temáticas. Consequentemente, o blogueiro usa tais informações para aumentar sua audiência, assim como o valor simbólico do circuito-Cardoso.

As experiências revelaram padrões de performance e interacionais tanto da parte dos(as) comentaristas quanto do próprio Cardoso. Os(as) comentaristas identificam experiências assim como os saberes exclusivos ostentados por Cardoso, como forma de atrair mantê-los como público visitante. Essas características corroboram o papel de destaque desempenhado por Cardoso, tendo em vista que, mesmo diante de críticas, os(as) visitantes favoráveis aos pontos de vista do blogueiro parecem se sobrepor à audiência crítica.

Ao tentar legitimar-se como uma microcelebridade, Cardoso se dirige a públicos heterogêneos. A heterogeneidade observada estimula a existência de conflitos, os quais são usados estrategicamente para manter a posição mediadora de Cardoso nesse contexto. Ou seja, as discussões inflamadas se tornaram possíveis pois todos(as) envolvidos(as) estavam envolvidos em performances nos blogs em análise.

Por outro lado, Cardoso concede o espaço do circuito-Cardoso para a ascensão de uma hierarquia entre comentaristas. Com base nisso, podemos perceber como os papéis são desempenhados e como cada indivíduo parece saber - ou tentar compreender - como se comportar nesses ambientes. Os(as) 
moderadores(as), pelo tempo de participação nesses blogs, assumem uma postura de direcionar novatos(as) assim como de repreender forasteiros(as).

Nesse sentido, as informações publicadas por Cardoso refletem o interesse do blogueiro em conquistar um espaço por meio de seus posts. Esse espaço é definido pela sua postura e, ainda, conquistado junto a audiências. Para tanto, Cardoso faz uso de experimentos para renovar suas performances e suas interações, assim como busca pela oferta de posts exclusivos em uma tentativa de tornar-se referência inclusive para outras mídias e outras microcelebridades. 


\subsection{Quem é Quem: disputas por legitimação}

- Reações dos(as) Comentaristas aos Assuntos abordados nos Posts

Publicar um ponto de vista, elogios, críticas ou, simplesmente, desejar participar das seções de comentários do Blog do Cardoso, do Contraditorium e do MeioBit pode determinar o modo pelo qual um(a) comentarista será visto(a) nesses ambientes. Além da forma de apresentar-se, o vocabulário e o tipo de abordagem feita indicam se o(a) comentarista é habitual ou forasteiro(a); se é um(a) salsinha ou membro(a) da "corte de Cardoso"; se é alguém que respeita as normas de convivência desses blogs ou alguém que pouco se importa com isso.

O comportamento dos(as) comentaristas funciona como parâmetro para identificar como o circuito-Cardoso o torna - e o legitima - como uma figura de destaque. Os comentários são meios de perceber a existência desses blogs, porque as participações tornam o processo de participação dinâmico e caracterizam que o blog está em atividade. Nesse sentido, as reações dos(as) comentaristas são parâmetros para confirmar a popularidade e o estilo peculiar de Cardoso e de suas performances ao dirigir-se às audiências.

Post 1: Ou dá ou desce, Bispo Macedo, publicado no Blog do Cardoso em 01/12/2005 - 1.181 comentários

JAQUELINE. 355 weeks ago

Amei esse video, quão inteligentes são vcs,realmente mas não ouvi ele obrigar alguem á dar o dinheiro. e outra eu tenho o suficiente para sustentar minha familia e as dos pastores. e vcs que não tem.Fazer o quê invejar, por que vc não tem nem onde cair morto .Cuide da sua vida que é melhor.

Thiago. 237 weeks ago

Eu me divirto com os comentários dos IURDiasnos que vem aqui reclamar do vídeo.O seu,Jaqueline, é de longe o mais engraçado.A começar pela sua afirmação de que os pastores não obrigam ninguém a dar dinheiro.E precisa?Devo avisar que os dízimos da universal e de outras igrejas são retirados por via psicológica.[...] Mas isso a gente até entende [ironia]os pastores são tão pobrezinhos,não é?O Edir Macedo,então,é um sem teto[/ironia].Finalizando,minha auto-estima ainda não está tão baixa a ponto de elogiar quem sustenta bandido.Já não basta ser explorada por políticos,a mulher ainda gosta de ser explorada por pastores...Por isso que eu digo.Tem gente que merece mesmo ser explorada.Afinal,chapel de otário é martelo de malandro.Passar bem!

jane. 223 weeks ago

já que você perde seu tempo criticando os outros,va agora procurar o que fazerou melhor venha trazer seu dízimo em uma IGREJA UNIVERSAL DO REINO DE DEUS, visite os templos e veja tambem para a onde vai os dízimos e ofertas. 
Post 2: Aviso aos crentes idiotas: Vocês serão banidos daqui, publicado no Blog do Cardoso em 21/08/2007 - 88 comentários

Zinicius 277 weeks ago

Também sou cristão. Conheço a podreira que se passa dentro de igrejas evangélicas muito melhor do que a maioria do pessoal que nunca freqüentou e fala de fora sem saber.

Isso não quer dizer que eu tenha deixado de acreditar em Deus, ou em Jesus como senhor e salvador. [...]Particularmente, eu não defendo pessoas idiotas, que, em bom "crentês", dão um verdadeiro "tristemunho" (conheces essa, irmão Wiener?). [...]No mais, leio o Cardoso porque acho legal. Nem sempre concordo com o que ele escreve, mas duvido que qualquer pessoa aqui que tenha um QI oscilante entre uma samambaia de plástico e uma ostra concorde com $100 \%$ do que qualquer pessoa diga

Post 3: $O$ que é pior: Matar 20 milhões de pessoas ou sacanear um pedaço de pão?, publicado no Blog do Cardoso em 15/01/2009 - 58 comentários

Crow. 201 weeks ago

A primeira vez que recebi (comi) a hóstia, achei sem sal e parecia que "ardia" na boca, fora que eu mordi e grudou no meu dente do fundo, tive que tirar com o dedo.

Oba, vou conhecer o Papa. :D[...]

Sidney. 198 weeks ago

É como dizem os cristãos (e muçulmanos e judeus) de boa índole: matem todos esses filhos da puta em nome de deus. (Isso é sarcasmo, pra quem não entendeu).

Bração.

Post 4: Atendendo a pedidos - mais ou menos, publicado no Contraditorium em $03 / 12 / 2008$

Vandro. 209 semanas atrás

PQP Cardosão !!!

Agora fiquei teu fã de uma vez !!!

Parabéns pela defesa dos bichos abandonados!

Tenho SEIS cães adotados, que apareceram ( um de cada vez, é claro) no meu portão, em estado de miséria total: Raquiticos, sarnentos, machucados, etc, etc...

Hoje, jamais trocaria qualquer um deles por um "ser humano", materialista, invejoso, vingativo, etc, etc, etc...

Alguem aqui assistiu ao filme "Os sete macacos" ???

Na minha opinião, ele retrata um futuro BEM PRÓXIMO para os ditos "humanos"...

Abraço.

Aqualate 209 semanas atrás

Excelente comentário ;D

Vandro. 209 semanas atrás

Se foi elogio, agradeço.

Se foi ironia, vá a merda.

Aqualate. 209 semanas atrás

Foi elogio ;)

Vandro. 208 semanas atrás

Um abraço. ;-)

Flávio Stealth. 209 semanas atrás

Não seriam Doze Macacos?

Vandro 208 semanas atrás

Seriam 12. Falha minha. Mas não invalidou o post. ;-)

Post 5: Haiti - terra amaldiçoada por Deus, publicado no Contraditorium em 13/01/2010 - 133 comentários

Arthurius Maximus. 151 semanas atrás

Nada mais perverso, egoísta e "sem noção" do que "um homem de Deus".

Gabriel. 151 semanas atrás

Gentleman... We have a WINNER...

A Verdade foi dita aqui.[...] 
Post 6: Brasil e Moçambique vão cooperar no desenvolvimento científico, publicado no MeioBit em 25/11/2008 - 396 comentários

gabrielmcf $\bullet 4$ anos atrás

Tudo bem Cardoso, vamos deixar a visão partidária um pouco de lado, esquecer do seu querido presidente Lula e dos seus amados companheiros petistas.[...]

Muito bonito. Não saímos do lugar, a África não sai do lugar. Os países ricos continuam crescendo e enriquecendo. Belo panorama.[...]

bquental $\bullet 4$ anos atrás

Estranho, porque o Cardoso não postou a notícia completa? O principal país com o qual o Brasil assinou um contrato de cooperação no continente africano foi a África do Sul, sendo o maior mercado de telefonia móvel na África e o 4 maior em expansão no mundo. Como o Brasil também é um mercado emergente em telefonia celular, nada mais normal se aliar a outro, pois ambos terão problemas parecidos.[...]

Não vi nada falando de uso de dinheiro público na fonte original do texto.

Muita teoria de conspiração, pouca informação...

Fonte: http://www.portugaldigital.com...

michelfernandes $\rightarrow$ bquental $\bullet 4$ anos atrás

Muito bem colocado, parabéns pelo comentário ![...]

UranoTienn $\bullet 4$ anos atrás

Engraçado como tem gente com mente fechada e visão extremamente infantil das paradas.

Que o Brasil é lerdo, faz coisas ruins nos sabemos.

Mas a visão politica de alguns chega a ser primaria.

Como o Fabião disse pra um, mas vejo que outros tb teriam que dizer.

Qual a idade de vc?

Não preciso perguntar pro Casdoso pq já vi a foto dele, sei q tem mais de dez anos, mas tem gente que tem cada visão, sendo pra direita como pra esquerda.

Só da pra acreditar que pegaram isso em filmes tendenciosos ou com documentaris idem

Triste isso

E se acham espertas

ritchie $\rightarrow$ UranoTienn $\bullet 4$ anos atrás

cara, realmente vc deve ta certo, pq eu não entendi nada do que quis dizer...

Carlos Cardoso $\rightarrow$ ritchie $\bullet 4$ anos atrás

e eu não estou disposto a tomar as mesmas drogas que ele, para poder entender o comentário...

GusTales $\rightarrow$ Carlos Cardoso $\bullet 4$ anos atrás

Faz bem.

Melhor ainda: "Eduardo acho estranho, melhor não comentar!"

\}:) [...]

UranoTienn $\rightarrow$ vitche $\bullet 4$ anos atrás

Que a maioria das pessoas se acham espertas, mas tem visões extremamente limitadas.

Tanto os de esquerda como os de direita.

E devem ter uns 10 anos pra pensar assim.

Simples

chuva $\rightarrow$ UranoTienn $\bullet 4$ anos atrás

Você é parente da JulianaPrado?

Post 7: Agora a Microsoft reinventa o Messenger, publicado no MeioBit em 28/04/2010 - 121 comentários

marcoantonio737 3 anos atrás

A galera que comenta no Meio Bit parece aqueles funcionários que quando a empresa atualiza um software todos ficam perdidos, sem saber o que fazer com a quebra da sua 'rotina' que tinham com o software antigo. Medo do desconhecido cria repulsão instantânea. Mas, com o tempo, o uso do novo software se torna natural e a vida continua, até que outra atualização apareça...

Eu gostei das novidades, pois o MSN é a única coisa 'social' que uso. 
As reações dos(as) comentaristas dos posts em exame determinam a posição ocupada por eles(as) dentro do circuito-Cardoso. Por conseguinte, o modo pelo qual esses indivíduos expressam suas opiniões qualificará como eles são vistos dentro daquele contexto e o nível de respeito concedido à sua participação.

A performance dos(as) comentaristas nos blogs analisados revelam a composição de dois lados: daqueles(as) que concordam com o que o blogueiro escreve; dos(as) demais que discordam da postura de Cardoso. Nesse sentido, as reações aos posts pretendem reforçar esses dois lados, gerando manifestações acaloradas por parte dos(as) defensores(as) e críticos(as) de Cardoso.

Percebemos a existência da preocupação em tentar expressar-se da maneira mais clara possível, de modo que sarcasmos e ironias possam ser interpretados de forma objetiva por aqueles(as) que, por ventura, lerão os comentários. Entre os(as) próprios(as) comentaristas, especialmente aqueles(as) que concordam com Cardoso, surgem pequenos atritos, tendo em vista que uma das partes não conseguiu interpretar o comentário conforme o esperado pelo(a) comentarista em questão. Porém, em seguida, o conflito é resolvido quando os(as) comentaristas explicam suas intenções.

As reações aos posts costumam ser desencadeadas pela publicação, quase sempre, de comentários com interpretações diferentes das aceitas por Cardoso e expostas em seus posts. Nesse sentido, o modo pelo qual um(a) comentarista interpreta as ideias contidas nesses posts determinará qual papel desempenhará no circuito-Cardoso e, ainda, como será identificado dentro desses espaços. Assim, ao notar que uma opinião contrária começa a ser propagada e ninguém realiza uma defesa aos pontos de vista de Cardoso - considerando que aqueles espaços são gerenciados pelo blogueiro -, a "corte de Cardoso", assim como seus(suas) defensores(as) se manifesta, favoravelmente ao blogueiro tomando parte de seu território.

Consequentemente, essa parece ser uma forma encontrada por Cardoso para fazer com que o seu público - corte e plebe - comente a respeito do post e, assim, tente apresentar elementos lógicos na composição de suas opiniões. Ou seja, essa tática parece propor tanto debates entre lados opostos quanto a defesa de seu espaço, especialmente considerando que Cardoso defende de forma autoritária os ambientes nos quais atua digitalmente. 
As interpretações e performances são determinados pelo estilo de Cardoso, pela abordagem de certos temas, assim como pela própria hierarquia simbólica do circuito-Cardoso. Os(as) mais próximos(as) de Cardoso - microcelebridades e a "corte de Cardoso" - parecem ter passe-livre para expor suas opiniões, mesmo que a intenção seja apenas para se expor perante aos(às) demais concordando com as ideias do blogueiro. Notamos a existência de pessoas que discordam e, ainda assim, fazem parte da "corte de Cardoso". Entretanto, essa discordância é parcial e busca esclarecer alguns pontos que, nos posts, ficaram obscuros e dão margem a interpretações ambíguas. Aqueles(as) que discordam e, ainda assim são membros(as) da "corte de Cardoso", ocupam posições privilegiadas e, aparentemente, conhecem Cardoso pessoalmente.

O esclarecimento de um(a) comentarista em tal posição parece tentar justificar a postura - assim como a inteligência prezada dentro de parâmetros estabelecidos pelo blogueiro - do(a) comentarista, como forma de ressaltar que, apesar do comentário desfavorável, ainda existe o interesse de fazer parte da corte e permanecer nela. Esse grupo parece acompanhar Cardoso com a pretensão de debater, discutir e, até mesmo, aconselhar o blogueiro que, nesse caso, não manifesta o sua performance peculiar quando é contrariado (arrogância, grosseria, etc.).

Como vimos, as reações pressupõem a defesa de pontos de vista de Cardoso como forma de manter os princípios norteadores das performances nesse circuitoCardoso. As manifestações costumam proteger as ideias do blogueiro, o território e o sentido de grupo, revelando que ideias contrárias as de Cardoso e de sua "corte" serão reprimidas e seus(suas) comentaristas correrão o risco de serem segregados(as).

\section{- $\quad$ Ostentação de saberes entre comentaristas}

O conhecimento aprofundado sobre algum assunto é uma das razões para comentaristas serem bem-recebidos(as) em debates no Blog do Cardoso, no Contraditorium e no MeioBit. Ao demonstrar entendimento apurado sobre os tópicos abordados por Cardoso nos posts, o(a) comentarista consegue destaque, ainda que este seja apenas para aquele post. Entender as referências apontadas por Cardoso, assim como trazer novas informações para o debate, é algo interessante, 
pois amplia a discussão. Embora possa ser questionado(a) ou criticado(a), o(a) comentarista ganha seu momento de fama, tendo em vista que faz parte de um debate com outros(as) comentaristas de Cardoso.

Além disso, a ostentação de saberes funciona como um parâmetro para equiparar-se aos(às) membros(as) da "corte de Cardoso" e ao próprio blogueiro. Uma vez que o comentário seja considerado relevante para o grupo, o(a) comentarista pode fazer inserções e construir a sua persona de comentarista para esses ambientes. Em um circuito-blogue em que a figura de destaque é denominada como "sabe tudo", percebemos a importância de mostrar conhecimento como forma de obter credibilidade e ter o seu comentário legitimado.

Post 1: Estupraram a Mônica!, publicado no Blog do Cardoso em 15/08/2008 112 comentários

André. 231 weeks ago

Tem retardado que lê mangá... Que REALMENTE entende quadrinhos jamais lê mangá. Compare qq mangá com Watchmen ou, se é pra ser esculachado de vez, com Sandman.

A propósito, notaram que eles não parecem estar mais no bairro do Limnoeiro? A Mônica parece patricinha da Barra da Tijuca.

Matheus B. Nicoletti· 231 weeks ago

Watchmen e Sandman não são argumentos o suficientes para desmerecer os mangás. Até porque, as últimas edições de Sandman tem influências fortes de mangás.

Só cuidado para não usar os sucessos atuais pré-fabricados do mangá como exemplo

Mariano Alves. 231 weeks ago

André, Pegou pesado no questão de tratar mangá como subgenero. Erro comum em generalizaçãoes. Só descrobi mangás a pouco tempo, porque sempre pensei em mangás como aminês, que realmente eu acho chato.

Existem coisas boas também. Ultimamente estou acompanhando GantZ e Death Note.

Gantz tem um roteiro bom e um desenho primoroso, em realismo de detalhes que dificilmente se vê em quadrinhos.

Death Note. Tem um das melhores histórias que já li em quadrinhos. Sem muito spoilers, o roteiro é altamente psicológico e todo focado em estratégia. Com uma grande área cinzenta entre o bem e o mal e focada principalmente no "vilão" da série.

Gantz - http://hqvertigem.blogspot.com/search/label/Gantz

Death Note - http://hqvertigem.blogspot.com/search/label/Death...[...]

jorge sobrinho 231 weeks ago

aí já não concordo. Há mangás bons e ruins, assim como há comics boas e ruins. Ou você quer dizer que Rob Liefeld é melhor que Katsuhiro Otomo (Akira)?

Você só quer fazer polêmica.

Filho Nogueira. 231 weeks ago

Cara, de boa, Akira é uma bosta. anime e mangá...

Ganhou fama pq tinham que colocar algum anime pra ser produto de exportação. Mas é muito ruim![...]

Andre. 231 weeks ago

Desculpem. Eu pensei que estava num Estado Democrático de Direito, onde posso expor qq opinião.

Mas, é claro que quem lê mangá não tem condições de entender isso. :)

Fê Medeiros 231 weeks ago

Não é pra tanto, né André... 
Tem muito mangá-reader aí que é abilolado mesmo, mas tem pessoas que lêem mangás e sabem das coisas. Eu lia mangás no passado (um que eu recomendo fortissimamente é Angel Sanctuary), mas tem poucos que são realmente bons.

Quer ver gente gente que dá vergonha? Só ver os carinhas da modinha Naruto.

Eu acredito que mangá e quadrinhos são coisas completamente diferentes, e comparar os dois vai dar merda. Então, o melhor é cada um no seu canto mesmo.

Rextops. 231 weeks ago

[...]Sugiro que o senhor dê uma espiada no "Delivery Corpse Service" ou coisa parecida que saiu pela Conrad (deve ser uma das últimas coisas a sair por esta editora). Um grupo de moleques com interessas macabros e mediúnicos oferece serviço a defuntos em troca de alguma grana.

Estou sendo muito sincero: são idéias pingando de novas e frescas.

[...]Recomendo muito uma olhada.

Outro bastante interessante e diferente é Seton.

Dê uma olhada. Tem muita porcaria no mangá. Mas também tem coisa interessante.[...]

amaury $1 . \cdot 227$ weeks ago

andré, vc está por fora

vai se informar um pouco mais sobre mangás pra dar seu recado

esse negócio de criar polêmica e depois falar em democracia é batido

assuma a sua ignorância em relação ao tema pois, fora os trabalhos mais comerciais existe muita coisa interessante como: ASTROBOY (que aborda questões relacionadas a preconceito)MONSTER, GEN PÉS DESCALÇOS (que trata do período da $2^{\text {a }}$ guerra no japão), entre tantos títulos que já saíram no país

as dicas foram de graça (hehe)

dizem que gosto não se discute, mas com um pouco de informação é sempre melhor (hehe) Thiago 231 weeks ago

Você tem consciência de que há um bocado de gente idiota que acha que ler comics é idiota, né? Pois é, o mesmo "racismo" ocorre com os mangas.

Pelo jeito é muito difícil lembrar que são só artes seqüenciais de hemisférios diferentes.

Bairrismo e xenofobia é que são comportamentos retardados.

Andre. 231 weeks ago

Japoneses são mestres em xenofobia, racismo e sexismo. Conhece alguma mulher na presidência de alguma empresa japonesa? Só aparecem nas subsidiárias em outros países. Lamento, pessoal, vão estudar um pouquinho da cultura deles e depois voltem pra falar comigo.

Se os mangás não tivessem aborrecentes seminuas com minúsculas saias pregueadas e vestidas de marinheiro, nenhum dos "aficcionados" continuariam aficcionados.

Post 2: Imagens exclusivas: terremoto no Haiti, publicado no Blog do Cardoso em 01/12/2010 - 215 comentários

Black Surfer. 152 weeks ago

Foda. E o pior é que o Brasil é o "padrinho" do Haiti. E se já estava dificil dar um jeito naquele país depois de tudo o que aconteceu, imagine agora.

RIP Zilda Arns. Essa decada não começou bem.

André. 152 weeks ago

A década começa em 2011.

Black Surfer. 152 weeks ago

A decada começa em 2010. Séculos que começam em anos terminados em 1.

Pode ver na wikipédia. ;)

Black Surfer. 152 weeks ago

Mais precisamente, aqui. http://pt.wikipedia.org/wiki/D\%C3\%A9cada_de_2010

André. 151 weeks ago

E existiu ano zero, inteligência? Também... leitor de wikipédia só pode dar nisso. Conte aí até dez: 1,2,3,4,5,6,7,8 e 9. 10 já é outra década. Duhhh

Black Surfer. 150 weeks ago

A decada de 0 foi do ano 1 ao ano 9. Indiquei a Wikipédia pq isso geralmente é o suficiente para ignorantes como vc, que falam como se fossem os donos da verdade e nem se dão ao trabalho de pesquisar.

Agora, vai lá, pesquise um pouco, seja um bom menino.

Black Surfer. 150 weeks ago 
Ok, retiro o que eu disse.

Não por achar que vc esté certo, mas por ver q o assunto é polêmico e, principalmente, nada tem a ver com o texto.

reivinny. 150 weeks ago

Caro andré, recomendo que é bom saber aceitar um questionamento.

O Black Surfer apresentou argumentos convincentes, e que condizem com a verdade.

Post 3: Controle de zoonoses não protege o seu bichinho - eu adorei, publicado em 13/01/2009 - 160 comentários

Lucas Duarte. 203 semanas atrás

Não vou discutir com você, de verdade, na internet qualquer um é machão, fala até de encontrar pra bater, pegar... de verdade, nunca te vi, seria errado de mais de minha parte, mas, vou arriscar dizer que pela tua maneira de escrever, és apenas um moleque idiota, nem ao menos importa tua idade, agora, acredite, eu partiria tua cara. Apenas para constar, meu filho que ainda nem tem tamanho para isso, não encosta a mão em mim, não vai maltratar animais, e educalo-ei como entendo ser o correto. Apenas, mais uma vez, constando, se um dia um rola-bostas como você encostasse um só dedo nele, te quebrava inteiro, acredite, ninguem fará isso, seja você quem for. de resto, apenas morra.

Pablo Célio 203 semanas atrás

Ae pode até bater na criança, agora no Dias não bate não...

Já vi o cara em cena e esse é carniceiro, pode levar a banca que não vai resolver.

abraço

PC $[\ldots]$

Cardoso 203 semanas atrás

Que coincidência, você tem o MESMO IP do Lucas... 201.90.200.130.

[...]

Pablo Célio 203 semanas atrás

Opa Cardoso,

Então, vc tem razão, temos o mesmo IP pois usamos a mesma rede, saimos pelo mesmo gateway para web, pelo visto você conhece bem superficialmente TCP/IP né?

Quando se tem uma empresa, ela contrata UM link para sair para internet, e a partir de um proxy/gateway distribui o acesso para a rede externa a partir de uma rede interna com ips inválidos(na internet) como 192.168.x.x

Se precisar de algum material relacionado a redes me da um toque, tenho uma porrada de tutoriais de quando tirei o CCNA(cisco) relacionado camada OSI/TCP, qq coisa posto lá no meu blog pra vc.

abração [...]

Post 4: Por favor, não matem os meus heróis, publicado no Contraditorium em 25/01/2011 - 105 comentários

Icaro. 97 semanas atrás

O texto é fenomenal, parabéns. Todo herói erra e qualquer vilão também pode ter um lado humano. Nos quadrinhos, o exemplo clássico de vilão com lado humano é o "Duas Caras", o qual era o melhor promotor público que a cidade jamais havia tido e após perder sua família e ficar desfigurado, entra em crise consigo mesmo. O próprio "Batman" vive uma dualidade consigo mesmo, alternando momentos de herói e vilão com o Batman/Bruce Wayne.

Na história antiga, além de Leônidas, tem também o exemplo do próprio Heitor, marido, pai de família, monarca e general exemplar, que no primeiro momento opta por querer entregar Helena para a morte aos gregos e em um segundo momento, a protege, inclusive, sacrificando a própria vida. Aquiles foi outro, que depois de tanto sangue derramar, é morto pela "flecha do arrependimento" ao tentar salvar a vida de Briseida.[...]

Post 5: Para Carl, publicado no MeioBit em 09/1 1/2010 - 143 comentários

Jones Linger $\bullet 2$ anos atrás

$\mathrm{O}$ valor de Sagan reside mais na sua filosofia que na ciência. Embora não tenha sido pioneiro (Aristóteles dizia o mesmo há milhares de anos), é difícil achar um filósofo nos dias de hoje.

Pryderi $\rightarrow$ Jones Linger $\bullet 2$ anos atrás 
@Jones Linger, Aristóteles não é aquele que dizia que não devíamos fazer experimentações, e que bastava pensarmos a respeito? Este Aristóteles?

Jones Linger $\rightarrow$ Pryderi $\bullet 2$ anos atrás

@Pryderi, Exatamente. Filosofia é isso: idéias, pensamentos que obviamente não pedem experimentações.

Jones Linger $\rightarrow$ Jones Linger $\bullet 2$ anos atrás

Nesse ponto de vista, a ciência é incompatível com a filosofia. Imagino as pedras que Sagan teve que quebrar para compatibilizar essas duas vertentes.

Lineu Bramma $\rightarrow$ Jones Linger $\bullet 2$ anos atrás

@ Jonas Klinger,

A filosofia é algum tipo de adoração à Aristóteles !?

:-)

Jones Linger $\rightarrow$ Pryderi $\bullet 2$ anos atrás

@Pryderi, o que o ser humano tem de singular, é a capacidade de acumular vivências . O conhecimento está nos livros para qualquer um. Não se deve, portanto, menosprezar aquele que tem idéias, assunto da filosofia.

Pryderi $\rightarrow$ Pryderi $\bullet 2$ anos atrás

@ Jonas Klinger, a Filosofia etimologiamente falando não tem nada a ver com as facurdadis de felozofia que estão por aí, onde seus bacharéis falam que Kant disse isso, Schopenhauer falou aquilo e Wittgenstein falou aquilo outro. eles mesmos não têm opinião própria. Para ter opinião própria, não preciso ler nenhum destes.

A propósito, Aristóteles era contra qualquer tipo de experimentação e é responsável pelo atraso da ciência em 500 anos. Coisa que o próprio Sagan reiterou.

chuva $\rightarrow$ Pryderi $\cdot 2$ anos atrás

@Pryderi, Aristóteles e a filosofia deram origem à lógica. Sem lógica, sem dedução de conclusões a partir de premissas. Sem lógica, sem ciência. Você pode atacar Aristóteles na base de que experimentação é importante em campos como Física, Química ou Biologia. Mas em áreas matemáticas, lógica e o poder dedutivo são tudo.

Em particular, sem lógica não haveria computadores, já que sua evolução está atrelada a esse ramo da matemática. E sem computadores, você não estaria aí hoje xingando Aristóteles... :) quanto a Cosmos, foi sim mindblowing. Mesmo para um moleque então...

Pryderi $\rightarrow$ Pryderi $\bullet 2$ anos atrás

[...]Lógica sem experimentação acarreta em resultados falsos, por causa de premissas errôneas. Exemplo: $20+25=45 ; 45^{2}=2025$. Assim, temos: $A+B=(A B)^{\wedge} 0,5$. Quer outro exemplo? 3025. Bem, $30+25=55.55^{2}=3025.2$ exemplos são poucos? Ok, $9801.98+01$ = 99. $99^{2}=$ ???? Consegue me dizer? Então, vejamos: a partir dos exemplos matematicamente perfeitos posso dizer: "Para achar a raiz quadrada de um número com 4 algarismos, basta eu separar este número mediante as 2 dezenas nas extremidades e somálas."

Lógica não representa verdades. Lógica TRANSFORMA verdades. Sem experimentação, não há Ciência. Deixe Aristóteles de lado e leia Popper e Khun.

thE Locker $\rightarrow$ Blaster Pryderi $\bullet 2$ anos atrás

@ Pryderi,

ahh eu ia até te defender, mas vc nao entende muito de logica... nem vem... seu exemplo foi completamento furado... você nem usou o principio da indução finita? fala sério...

Post 6: DMR - Eulogia a um Gigante, publicado no MeioBit em 14/11/2011 - 141 comentários

Romero Carvalho De Antunes • um ano atrás

Da mesma forma que Newton reconheceu que se apoiou sobre o ombro de gigantes, Jobs se apoiou em DMR. Uma pessoa fez até uma comparação bem pertinente: DMR está para Jobs assim como Tesla estava para Edison.

Elildo Jesus $\rightarrow$ Romero Carvalho De Antunes • um ano atrás

Essa comparação é completamente sem sentido. Tesla e Edison eram rivais e defendiam áreas completamente díspares da Eletricidade.

Romero Carvalho De Antunes $\rightarrow$ Elildo Jesus • um ano atrás

Exceto se você encarar pelo fato de um ter dado contribuições científicas de grande valor (Tesla/DMR) e outro ter criado ferramentas para o homem comum utilizando-as (Edison/Jobs). 
André $\rightarrow$ Romero Carvalho De Jesus • um ano atrás

Discordo. Se dependesse de Edison estaríamos usando eletricidade em corrente contínua, enquanto Tesla não só defendia a corrente alternada como previu que a eletricidade poderia ser transmitida pelo ar até as casas. Tesla estava certo em ambos os casos. Só o abastecimento de eletricidade sem fio que ainda não saiu do papel (mas já provaram ser possível).

Roberto Genaro $\rightarrow$ André $\bullet$ um ano atrás

Depois de ler as biografias e assistir um documentário, eu diria que o Tesla, como cientista, foi maior que o Edison.

André $\rightarrow$ Roberto Genaro $\bullet$ um ano atrás

Edison não era o que podia se chamar de "cientista". Ele não buscava o porquê das coisas. Ele preferia a aplicação prática. Foi um homem muito importante na História, mas como inventor. Tesla, por outro lado, não só era um excelente cientista como um visionário também.

André $\rightarrow$ Romero Carvalho De Antunes • um ano atrás

Newton não reconheceu nada. Isso foi uma piada sarcástica direcionada a Robert Hooke, pois este era nanico.

Romento Carvalho De Antunes $\rightarrow$ André • um ano atrás

André, isso é especulação. Hooke não tinha baixa estatura e os dois não tinham inimizade no início. Trocavam cartas em tom ameno constantemente antes dos trabalhos de Ótica que Newton publicou.

Como é algo aberto a interpretações, prefiro acreditar que este foi um dos poucos momentos de humildade de Newton.

André $\rightarrow$ Romero Carvalho De Antunes • um ano atrás

Para sua informação, Newton criou briga com todo mundo. Leibnitz era um de seus grandes fãs e até com ele Newton criou caso por causa do Cálculo Diferencial e Integral, cuja autoria foi reconhecida como sendo de Newton por parte de um comitê selecionado pelo próprio Newton. Era maníaco, neurastênico, arrogante e dado a ataques de fúria. Hooke não era flor que se cheirasse tb.

Bibliografias: Dança do Universo, de Marcelo Gleiser

Breve História do Tempo, de Stephen Hawking

Newton e os universos paralelos, do site do Ricbt

Mostra a sua bibliografia de apoio, por gentileza (se mencionar a Wikipédia, me reservarei o direito de rir de vc).

André $\rightarrow$ Romero Carvalho De Antunes • um ano atrás

Mais uma coisa: óbvio que ambos trocavam cartas. Antigamente não se xingava no Twitter, os xingamentos eram através do correio, mesmo. Até Huyggens entrou no bate-boca sobre os anéis de Saturno (Huyggens estava certo e Newton estava errado nesse caso). Newton foi um gênio, mas é inegável que ele roubou o trabalho de muita gente, publicando como se fossem seus (ah, sim! Ele não inventou o telescópio refletor tb).

João Vinicius Blablabla $\rightarrow$ Romero Carvalho de Antunes • um ano atrás

"Da mesma forma que Newton reconheceu..."

Não foi Einstein que "reconheceu" isso ???

Romero Carvalho de Antunes $\rightarrow$ João Vinicius Blablabla • um ano atrás

Não, foi Newton.

A ostentação de saberes no circuito-Cardoso é uma performance bastante praticada pelos(as) comentaristas dos posts em exame. O conhecimento é bastante valorizado nesse contexto, principalmente a partir de inferências feitas pelos(as) comentaristas acerca do post de Cardoso. O acréscimo feito por esses indivíduos às publicações de Cardoso amplia interpretações e, de certa forma, enriquece e dá legitimidade à abordagem feita pelo blogueiro. 
Por outro lado, a ostentação de saberes parece ser uma forma de demonstrar que o(a) comentarista em questão está apto(a) para participar das discussões por deter tanto conhecimento quanto Cardoso faz questão de ressaltar que tem. Sob outra perspectiva, a ostentação de saberes repete as ideias de Cardoso e, por conseguinte, a sua forma de se comportar no circuito-Cardoso sendo mimetizada nas performances daqueles(as) que exibem saberes e conhecimento perante os(as) demais.

Conseguir interpretar as ideias de Cardoso sob o ponto de vista do blogueiro constitui uma importante credencial para participar do circuito-Cardoso. Quando o conhecimento é desconhecido pela maioria, o(a) comentarista recebe maior atenção e, consequentemente, pode vir a gerar uma thread a partir do que foi colocado no comentário. Entretanto, se os saberes compartilhados provêm de fontes questionáveis (a Wikipedia é um dos exemplos mais citados), o(a) comentarista perde credibilidade e a sua performance, como detentor(as) daquele saber específico, fica prejudicada.

A ostentação de saberes permite ao(à) comentarista tentar receber atenção de Cardoso de uma forma privilegiada. Se o blogueiro admite que, dentro de seus padrões, pessoas inteligentes são melhores, logo, sob esta ótica, o(a) comentarista dotado de saberes, expostos da forma de comentários, teria uma receptividade maior por parte de Cardoso. Nesse sentido, todas as oportunidades de demonstrar ser "conhecedor(a)" de algo são aproveitadas, principalmente se esse saber não for conhecido pela maioria.

\section{- $\quad$ Debates e Discussões entre Comentaristas}

Cardoso costuma dizer que é favorável ao debate e, sempre que possível, publica posts com a intenção de estimular discussões entre seus(suas) comentaristas. Na maioria dos casos, os temas são polêmicos e as estratégias usadas por Cardoso, para expressar sua própria opinião, são consideradas controversas por seus(suas) críticos(as). O uso de mensagens subliminares, referências sutis, assim como piadas, sarcasmos e ironias, contribui, de certa forma, para essa interpretação.

Tal e qual em uma arena, cada comentarista tenta impor seu ponto de vista, levantando sucessivas questões e argumentos que, por sua vez, defendem como 
ideais. O próprio Cardoso, em algumas ocasiões, participa do debate como forma de reafirmar o posicionamento levantado por ele mesmo no post comentado.

Dentro do que observamos, o debate é uma característica comum nos posts analisados e, quase sempre, é motivado pela abordagem peculiar de Cardoso acerca de temas que são polêmicos no âmbito de cada blog.

Post 1: $O$ que é pior: Matar 20 milhões de pessoas ou sacanear um pedaço de pão?, publicado no Blog do Cardoso em 15/01/2009 - 58 comentários

pablo raquelis. 203 weeks ago

Se a igreja é tão irrelevante ou passível de desprezo de suas doutrinas o que importa o que eles consideram pecado maior ou menor? Santo Cristo, eles ainda acham que o uso de preservativos é errado - mesmo com trilhares de DSTs aí para todos que não praticam sexo seguro pegarem.

Fazer alarde em cima de algo que é julgado, no próprio texto como sem sentido, é tão irrelevante quanto ao fato em si. O texto tornou-se, infelizmente, incoerente.

William Latencio. 203 weeks ago

Sua lógica é muito complexa pra mim. Ou você não sabe usar as palavras "irrelevante" e "incoerente".

pablo raquelis. 203 weeks ago

Ou a terceira opção: Eu usei a palavra "incoerente" ao invés de repetir a palavra irrelevante por descuido pois tinha escrito uma coisa e depois mudei.

Sinta-se à vontade, é claro, para continuar concluindio que eu não sei usar palavras ao invés de ter cometido um deslize como qualquer ser humano. Quem dera todos fôssemos deuses não?

William Latencio. 203 weeks ago

Bom, eu não vou discutir semântica, principalmente depois que você admitiu o erro. Continuo achando que NÃO é irrelevante uma religião que é a mais influente no mundo ocidental e seguida por bilhões de pessoas.

Esta frase final sobre "sermos todos deuses" daria pano pra muita manga mas hoje não estou inspirado.

Post 2: Imagens exclusivas: terremoto no Haiti, publicado no Blog do Cardoso em 12/01/2010 - 215 comentários

tiao. 151 weeks ago

Cara... piada infeliz mesmo. Se tua mãe tivesse morrido lá tu faria a mesma piada ?

Cardoso. 151 weeks ago

Eu jamais deixaria minha mãe ir pro Haiti

tiao 151 weeks ago

Se tua mãe fossê a Zilda Arns não seria você que impediria ela de ir. E agora estaria se lamentando. Pense na tua sorte. Falta a você se colocar no lugar dos outros. Te dou um desconto nesta pela tua idade

LEANDRO. 151 weeks ago

CREUUUUUUUUUUUUUUUUUUUUU

Gabriel. 151 weeks ago

E me explique porque o Cardoso ou qualquer um deveria se colocar no lugar de alguem? Isso é a coisa mais imbecil que eu já ouvi.

Eu acho minha vida e meu bem-estar muito mais importantes do que $99,99 \%$ das pessoas.

Se voce não pensa assim, se mate e doe todos seus orgãos, há muitas pessoas que precisam...

tiao. 151 weeks ago

Explicando então já que voce não sabe. Isto se chama EMPATIA. Para facilitar teu trabalho vai aqui .... http://br.answers.yahoo.com/question/index?qid=20... ou vai no google e procura por "significado da palavra empatia"... sem preguiça por favor...

Em suma. Não deseje aos outros o que não quer pra você mesmo. captou ? 
Mais um desconto

Gabriel- 151 weeks ago

Sabe o mais engraçado, conheço muito bem o significado e o conceito da sua maravilhosa "EMPATIA", mas, simplesmente a descarto porque não me tem nenhuma utilidade.

André. 151 weeks ago

HAHAHАНАНА

Ponto pra ti. :)

tiao. 151 weeks ago

Empatia só é util pra você quando OUTRA PESSOA sente por você..

Exemplificando ... Tu leva um tiro e fica sangrando até morrer no meio da rua...

Espero que alguem sinta EMPATIA por você e imagine-se no teu lugar pra chamar uma ambulância... se não sentir EMPATIA vai acabar de te matar pra ficar com os orgãos... hahahahah

Gabriel-151 weeks ago

Ahn, WRONG!!!!

Nesse caso "EMPATIA" é o de menos, pois, ao vivenciar essa situação é OBRIGAÇÂO de qualquer pessoao, por LEI chamar o socorro. Caso contrário é configurada omissão de socorro que, caso não saiba é crime. Fikdik. ;)

tiao. 151 weeks ago

hahahah... não estamos falando do exemplo em si mas sim do significado dele. Poderia ser você sem guarda chuva numa enchente em São Paulo e ninguém te dar carona de carro. Dá no mesmo. Engraçado que reclamam de quem não conseguiu ver a critica social por trás da piada de mau gosto mas você não consegue ver a didatica do meu exemplo. Como diria o Adam: "eu rejeito a sua realidade e substituo pela minha".

Pra encerrar, seguindo o raciocinio da sua resposta anterior escolha uma das abaixo:

a) Eu nunca saio de casa sem guarda chuva.

b) Eu tenho carro e nunca ando a pé.

c) Eu tenho carro e um gurada chuva de baixo do banco.

d) Não pego carona com estranhos

e) Não moro em São Paulo

f) Tenho paralisia cerebral e não sai de casa quanto mais com chuva. Inclusive estou te respondendo teclando com um canundino na boca.

e) Chuvaaaa... Estou em Nova York e tá o maior frio aqui. :-P

Gabriel- 151 weeks ago

O "significado" do seu exemplo é insignificante, por isso o ignorei sumariamente.

E se tivesse entendido minha primeira resposta veria que sua frase "eu rejeito a sua realidade e substituo pela minha" é perfeita.

Repetindo, minha vida e bem-estar estão acima dos de qualquer outra pessoa. Isso é uma decisão minha, referente a minha vida e não está aberta a discusão.

Só para terminar, referente as opções bestas, a unica mais proxima seria a "D", acrescentando que não pegaria carona nem com conhecidos, preferiria tomar chuva.

tiao 151 weeks ago

hahaha... muito divertida esta discussão... mas já que eu não consigo te ensinar nada mesmo vou deixar esta tarefa para o TEMPO... resumindo... joguei a toalha ... :-D

Entretanto voce me surpreendeu. Não esperava que escolhesse uma das alternativas. :-O. Não era esta a idéia a principio e pra variar tu não entendeu nada.

Felizmente nunca vou te conhecer pessoalmente.

Segue minha última aula gratis aqui :[...]

Gabriel- 151 weeks ago

HАНАНАНАНАНАНАНА

Descobrimos algo em comum, tambem fico feliz em nunca te conhecer pessoalmente, costumo manter distancia de hipocritas como voce...

E na boa, não tenho nada a aprender de gente como voce.

Alias como voce citou o quesito idade duas vezes, já descobri sua laia.

Voce é daqueles velhos insuportaveis, que não tendo o que fazer anda de onibus só porque não paga e atrapalha quem realmente precisa usar...

Salvador Hernandez. 151 weeks ago

Alguém que tira suas dúvidas pelo Yahoo!Respostas não merece credibilidade. Nem resposta. 
antônio 151 weeks ago

todo esse pessoal dodoizinho,daki 2 semanas nem vai se lembrar q o Haiti existe... hipocritas.

Mario Jose Serran. 151 weeks ago

Concordo!!!

O Big Brother está aí, para embrutecer ainda mais este povo sem leitura.

Post 3: Controle de zoonoses não protege o seu bichinho - eu adorei, publicado no Contraditorium em 13/01/2009 - 160 comentários

Pablo Célio 203 semanas atrás

Quanto a ir a merda acho que não é uma boa. Vou passar.

+ Então, me desculpa, eu não queria te deixar nervoso, apenas foi um ponto de vista divergente, acredito que com a divergência podemos crescer, não adianta muito eu agir como um boi no rebanho e ir para o mesmo lado que todos, pois, isso não acrescenta muito, e por outro lado, você me parece um cara inteligente, tenho certeza que não precisa de afagos no ego para ficar bem. [...]Sinceramente, as vezes tb sinto vontade de esmagar crianças quando elas são como você citou, uns diabinhos, porém nem tudo que sinto vontade posso fazer não é mesmo?

Abração [...]

Douglas Ágora 203 semanas atrás

Afirmar que todos aqui são puxa sacos é algo realmente ridículo. Acredito que temos gente com raciocínio aqui para formar a própria opinião. Ninguém aqui é idiota como você mesmo afirmou.

Talvez você seja mais um que acredite que todo mundo que lê blogs tem mentalidade de 10 anos de idade (como os que assistem a novela em média tem, conforme pesquisas de comunicação que eu estudei).

Fato é: você foi ofensivo para com os outros, e apenas recebeu o que mereceria.

Psicologia só funciona no Programa da Supper Nanny, onde tudo é uma maravilha com o cantinho da disciplina e outras tranqueiras mais. [...]A questão que foi posta em primeiro lugar neste artigo foi: Os animais devem realmente pagar pela nossa incompetência em educar nossas crianças?

Particularmente eu gostaria que a criança fosse brincar com um animal capaz de se defender. $\mathrm{O}$ animal mesmo daria a resposta, seria muito mais legal!

Pablo Célio 203 semanas atrás

Douglas Ágora, eu não pretendia ofender ninguem e nem falei que você é retardado mental, leia novamente e vai perceber que está se martirizando de bobeira.

[...]Lembre-se que esta é uma ferramenta de comunicação onde muitas pessoas vão ler e ao ver todos aqui fazendo apologia a violência contra crianças podem ser influenciados. Já pensou se um dia resolver ter um filho e alguem vai dar uma boa lição nele?

[...]Mudando de assunto, qual sua formação acadêmica? é na area de comunicação? Desculpa alguma coisa viu.

Abraços

$\mathrm{PC}[\ldots]$

Douglas Ágora· 203 semanas atrás

Eu não estou me martirizando, somente estou explicando e exemplificando que foi bastante infeliz em seus primeiros comentários por aqui. Se pode visualizar teu erro ao menosprezar os outros, então está tudo bem. Particularmente não me sinto ofendido, pois sei bem o que eu acredito enquanto pessoa.

Bem, concordo contigo neste segundo ponto. Acho que apologia a violência não deve ser praticada, e que realmente alguns são extremistas ao ponto de exagerar. Mas, em defesa de um animal meu eu repito, seria capaz de qualquer ato.

[...]Hoje sou apenas um mero formando em Jornalismo e tenho conhecimentos na área de Radialismo e Design Gráfico para composições jornalísticas, basicamente isto além de outras experiências.

Pablo Célio. 203 semanas atrás

Oi Douglas,

Está certo, nunca devemos menosprezar os outros! Devemos discutir atitudes e não pessoas, não é mesmo?

Enfim, essa foi a unica forma que o Cardoso encontrou de resolver o problema, porém vamos lembrar que mapa mental é diferente de território, portanto, apesar de ter 
funcionando nesse caso, eu só sugeri que além desse, existem outras formas de resolver o mesmo problema, que talvez possam trazer resultados melhores no geral. Eu também errei ao me expressar, percebo algumas pessoas ficaram bravas comigo, portanto não fui eficiente em minha comunicação né... a vida é assim, todo mundo escorrega rs

[...]Gostei bastante do Blog aqui, permite discussões e troca de pontos de vistas entre pessoas que pensam muito diferente e todos podem sair ganhando muito.

Abraços

PC $[\ldots]$

Evandro 203 semanas atrás

Quem protege o culpado (a criança sem educação) pune o inocente (o cão sem condições de reagir). E isto é válido para absolutamente tudo o que vemos no nosso dia a dia. Proteger o culpado SEMPRE é punir a vítima.

Pablo Célio 203 semanas atrás

Então você é a favor de fazer justiça com as próprias mãos? Posso começar a usar a minha espingarda calibre 12 para resolver diferenças na rua que eu achar um inocente e um culpado? Será que eu tenho condição de julgar quem é o inocente e culpado? Então tudo bem, é certo que ele bata no menino que bateu no cachorro, e seguindo essa lógica é certo que o pai do garoto bata nele? e ai ele ganha o direito de bater no pai do garoto? que por sua vez ganha o direito de mandar matar ele? Como assim?! Vamos ser coerentes, não da pra ver o mundo só de um ponto de vista conveniente...

$[\ldots]$ abraço

PC $[\ldots]$

Evandro. 203 semanas atrás

1) Andar na rua armado é crime, a menos que você tenha permissão para isto (o que duvido muito visto a altissima exigencia para tal). E ter permissão para andar armado lhe da o direito de sair atirando a seu bel prazer. Alias, sequer a polícia tem este direito.

2) No que tange a repreensão, caso você veja algo errado pode sim repreender a pessoa. NADA, absolutamente NADA o impede disto. O que você não vai poder é sair distribuindo socos e chutes (o que não foi o caso citado pelo Cardoso). Mas se alguém lhe mandar um brinquedo de borracha porque você não pode pega-lo e mandar de volta? O que não dá (legalmente) é para alguém lhe mandar um brinquedo de borracha e você responder jogando-lhe o carro em cima. O legalmente que eu cito é devido ao fato de nossa lei não permitir respostas desproporcionais, assim, se alguém lhe aponta uma faca nem ouse puxar uma arma porque você perde a razão (o que acho uma tolice).

3) Trazendo mais para a realidade do ocorrido. A mãe deveria ter repreendido o garoto e não o fez. Ela errou e o Cardoso decidiu tomar partido do animal de estimação dele, o que fez bem, principalmente ao garoto. Da próxima vez talvez ele pense duas vezes antes de agredir algum animal pois alguém poderá responder por ele. Da mesma forma como o Cardoso mandou o brinquedo de volta, se fosse na rua e ele batesse em uma outra criança, pode ser que o irmão maior não fosse tão gentil como o Cardoso e mandasse ele de fato para um hospital tamanha a surra.

Pablo Célio 203 semanas atrás

1) Sim é claro, eu usei ironia para demonstrar o quanto o que você disse era sem noção. Eu perguntei se acha certo isso? A resposta é não ok? Concordo contigo, também não acho certo, assim como não acho certo o Adulto que pune criancinhas de 4 anos de idade, salvo as devidas proporções, a relação é a mesma, ou seja, ele fez justiça com as proprias mãos, portanto se seguirmos o item 1) ele está incorreto pois infringiu a lei batendo em uma criança.

2)Segundo o Autor do ato, a criança com 4 anos conseguiu machucar o seu cachorro com o briquendo, portanto o brinquedo não deve ser um simples brinquedinho de borracha certo? e o mesmo brinquedo que machucou o cão sendo atirado por uma criancinha foi atirado por um adulto com força, o que deve ter feito um estrago maior que o cão sofreu né? Sendo assim se causar lesão na criança o adulto pode ser punido pela lei não é mesmo?

3)Concordo que a mãe deveria ter intercedido e falhou! Já o Cardoso se justificar dessa forma para poder usar sua força desproporcional para bater na criança não deve ser visto com bons olhos para qualquer pessoa que seja NEUTRA, ou seja, que não tenha nenhum laço de amizade com o adulto envolvido no processo. [...] Realmente está sendo imparcial quando responde aqui no site ou fala isso por ter alguma afinidade com o autor? abraço

PC [...] 
Evandro 203 semanas atrás

Afinidade moral. Mas eu não sou do tipo imparcial. Considero imparcial a pessoa que fica em cima do muro e não quer desagradar nenhuma das partes. [...]

Eu SEMPRE tenho lado. Poderia estar do seu lado, mas neste caso eu estou do lado do autor do post.

Quando você pergunta se eu estou sendo imparcial está tentando me desacreditar ou tirar o mérito de minhas argumentações. Ser favorável ao autor não me torna menos digno de crédito e você sendo contra não o torna mais digno de crédito.

Pablo Célio. 203 semanas atrás

Entendo, então respeitando sua resposta, desculpe por sugerir que você era amigo do autor.

Vou simplismente colocar a minha opinião:

A criança que jogou o brinquedo está errada, e deveria ser punida, ou pela mãe, ou bronca do adulto em questão, porém nunca bata no filho dos outros.

$\mathrm{O}$ adulto que agrediu a criança, também está errado, pois apesar de mal criada e malvada, é uma criança, e ele(o adulto) tem maturidade para reconhecer a sua desproporção de sua força com relação a da criança. Não é assim que se resolve problemas sociais, se todos começarem a agir dessa forma, agredindo alguém quando essa pessoa faz algo que vai em desacordo com suas crenças, a vida social seria inviável.

abs

$\mathrm{PC}[\ldots]$

Post 4: Haiti - terra amaldiçoada por Deus, publicado no Contraditorium em 13/01/2010 - 133 comentários

Indefinidus. 151 semanas atrás

A sua crítica social pode ser percebida até por um macaco...mas o que torna revoltante, é uma pessoa fazer uma crítica dessas ainda no calor dos acontecimentos, enquanto pessoas mutiladas estão sem médicos,mortos estão espalhados pelas ruas, sem condição de serem identificados.Esta postura é digna de um alienado que vê o mundo de dentro do seu apartamento, ou pior ainda, tenta "sentir"o mundo através do seu computador, e não sabe o que é conviver com pessoas, e nem respeitar as diversidades e a dor alheia.

Você foi fraco,acusando o pastor para ofuscar a infeliz comparação que você fez num momento de pesar de tantas famílias.

Aceite que o momento não foi oportuno e desculpe-se, pois tivemos várias situações no Brasil onde poderiam ser feitas comparações semelhantes, e você não fez. (pelo menos eu não vi) [...]Saudações.

Cardoso 151 semanas atrás

1 -- fraco é você, que se esconde atrás da covardia do anonimato.

2 -- vá reclamar com o consul do Haiti.[...]

Mário José Serran. 151 semanas atrás

Querem ver o que é o haiti, vocês que nem sabem onde é que fica?

Este é o relato de um viajante em 1892:

http://docs.google.com/Doc?docid=0AX18bnGq118vZG1 ...

De lá para cá pouco mudou.

Salvador Hernandez 151 semanas atrás

Até 2 minutos atrás eu até discordava da maneira como Cardosão colocou os fatos. Mas acabei de ver num diário do Uruguay:

http://www.elpais.com.uy/100119/ultmo-466352/ulti...

Então, diante destes fatos, que eu sei que não são novos, e para por um ponto final neste meu ponto de vista:

TOMARA QUE ESTE POVO SEJA TRAGADO PELO MAIOR TSUNAMI DA HISTÓRIA DA HUMANIDADE, HAJA VISTO QUE SE MATAM ENTRE SI NO MOMENTO DE SE AJUDAREM (NADA DIFERENTE DAQUI, ADMITO)[...]

PRA FALAR A VERDADE: FODA-SE O HAITI.

Francisco Vasconcelos. 150 semanas atrás

Salvador há de se entender que estas pessoas vivem o inferno há anos.

Não é a mesma coisa do pessoal que perdeu sua vida "tranqüila" com um rio que transbordou e destruiu tudo em sua casa.

Uma coisa é passar pelo inferno, outra é viver anos nele. 
Post 5: Brasil e Moçambique vão cooperar no desenvolvimento científico, publicado no Meio Bit em 25/11/2008 - 396 comentários

QBBFTWGMO $\bullet 4$ anos atrás

Sinto que esse post está a um pulinho de gerar comentários racistas...

magnum $\rightarrow$ QBBFTWGMO $\bullet 4$ anos atrás

eu gostei do "A Nokial e o resto do Japão que se cuidem, no futuro será verde amarelo e preto (as cores da bandeira de Moçambique, nosso glorioso parceiro rumo ao futuro)!"

tipo, ainda bem que explicou....

mas o jeito menos agressivo seria:

"A Nokia1 e o resto do Japão que se cuidem, no futuro será verde amarelo e AFRODESCENDENTE(as cores da bandeira de Moçambique, nosso glorioso parceiro rumo ao futuro)!"

Barba $\rightarrow$ magnum $\bullet 4$ anos atrás

Esse jeito não só seria mais agressivo como mais estúpido. É a bosta de uma cor, pare de fazer drama.

magnum $\rightarrow$ Barba $\bullet 4$ anos atrás

não é drama, é sarcarmo,

tudo mundo faz isso aqui.

eu tambem quero fazer um pouco...

Barba $\rightarrow$ magnum $\bullet 4$ anos atrás

Você, senhor, é uma monstruosidade do sarcasmo.

magnum $\rightarrow$ Barba $\bullet 4$ anos atrás

obrigado!

você tambem é muito bom nisso...

Fabião $\rightarrow$ magnum $\bullet 4$ anos atrás

O problema aí é justamente este:

Quem comentar enxergar "preto" aonde só se fala de "pobre".

Se fosse um acordo de cooperação com o Cazaquistão, garanto que o Cardoso escreveria a mesma coisa.[...]

Carlos Cardoso $\rightarrow$ Fabião $\bullet 4$ anos atrás

Mas seria ilustrado com uma foto do Borat, aí apareceria um idiota para dizer que o Sacha Cohen era inglês, e terminaria com uma acusação de anti-semita para cima de mim.

Pryderi $\rightarrow$ Carlos Cardoso $\bullet 4$ anos atrás

In Godwin we trust.[...]

Barba $\rightarrow$ Pryderi $\bullet 4$ anos atrás

Koeh, o cardoso é anti-semita! Ele cospe em Ali e sua etnia, usa o nome de seus seguidores em vão. Also ele não curte as idéias de Israel.

cylons $\rightarrow$ QBBFTWGMO $\bullet 4$ anos atrás

Começou pela foto do tópico. :)[...]

Post 6: Linux atinge a marca histórica de 1\% do mercado, publicado no MeioBit em 02/05/2009 - 303 comentários

Indefinido $\bullet 4$ anos atrás

Não não nao...

falem a verdade tem que ser macho pra falar mal do linux

(mereço uma insignia de machon agora)

Isso voce nao pode negar[...]

ywerosp $\rightarrow$ Indefinido $\bullet 4$ anos atrás

[...]Pronto! taí a tua insigna de machon...[...]

GusTales $\rightarrow$ Indefinido $\bullet 4$ anos atrás

[...]Quem quiser Epics Fails, é só clicar na imagem lá em cima que eu postei, logo no primeiro fail

P.S Uso Windows e acho o Linux uma porcaria para as minhas necessidades.. e aí? Sou

Troll? :P[...]

Indefinido $\bullet 4$ anos atrás

Cardoso por favor remova o rotulo que estes nerds colocaram depois do meu nome, eu nao pedi pra usar, vou usar o que eu puder comprar com meus tibs, pelo menos tenho honra de vir aqui e falar que to de saco cheio com essa fantasia do linux, tem muito cara 
que adoraria jogar o seu fora mas por pressao da comunidade instala o windows por baixo do pano no wine e fica brincando de ser feliz auheauheuaheuaheaeae

a desculpem vou jogar eve online, guild wars e outras coisitas a mais que infelismente pinguim so fica chupando o dedo auheauheauheauheauhe

GusTales $\rightarrow$ Indefinido $\bullet 4$ anos atrás

[...]FeliZmente, pingüins não tem dedos...[...]

Lucas Tiesto $\rightarrow$ GusTales $\bullet 4$ anos atrás

Que tipo de embasamento tem uma salsinha destas?

Salsinhas com embasamento?

Ahn... Tá... Esquece :-)

Vo morrer, vo doar minhas córneas e num vou ver tudo!!!

Pryderi $\rightarrow$ Indefinido $\bullet 4$ anos atrás

O salsa acha que fomos nós que colocamos as (merecidas) insígnias nele. НАНАНАНАНАНАНАНАН

Dêem uma de salsa a ele, por favor.

O dia hoje tá show de bola hahahahaha[...]

Indefinido $\bullet 4$ anos atrás

voce esqueçeu de completar tard feliz porque eu aproveito reamente tudo da internet :) (agora voce so fica nessa vidinha de chamar os outros de tard e nao aproveita nada)[...] gaviao_molhado $\rightarrow$ Indefinido $\bullet 4$ anos atrás

[...]"Kernel nas nuvens" - Esse cara além de Troll e Tard ainda é Salsa, acho que temos um novo recorde aqui.

PS: O Windows Seven provavelmente será o melhor Windows já feito até o momento, mas se ele fosse perfeito a Microsoft fecharia as portas rapidamente, já que ninguém compraria uma versão posterior do windows.[...]

Alan Menzy $\rightarrow$ Indefinido $\bullet 4$ anos atrás

Isso, continue assim, para a nossa alegria!

Tem muito carinha aqui que mal saiu das espinhas e acha que abafa...

Ta ficando insuportavel pessoas que não respeitam opiniões das outras!

$[\ldots]$

Vinicius_Espada $\bullet 4$ anos atrás

Sindrome de programador.

Os programadores fazem programas, aplicativos para serem utéis a eles mesmos, mas não a pessoa comum que não conhece uma linguagem de programação, que não saca de hardware, provavelmente tem dificuldades em saber usar o próprio google.

[...]O problema do linux não é o OS. É os tards. É a falta de visão do futuro. Eles olham muito para o próprio unbigo falando de termos de comunidade. Do que adianta portar um OS para todos os celulares, destops e consoles de videogame possiveis, se os programas e jogos são muito mais restritos e inferiores a aplicações comerciais de verdade?

[...]Gosto do kurimin, do ubuntu... E já usei fedora e slackware. Linux é otimo sistema operacional e tenho na minha hd no dual boot com windows xp, mas ainda falta muito para eu largar a microsoft e me juntar a galera. Idealismo e open source não pagam meu salário. usar programas eficientes e confiáveis, sim.[...]

Angelo_Guilherme $\rightarrow$ crazies $\bullet 4$ anos atrás

Tudo bem que se unissem as forças mas eu acho que seria meio complicado administrar um projeto com 100000 de pessoas envolvidas no desenvolvimento...

se fossem duas distros boas (ex: Ubuntu e Slackware) ai no mundo existiria a possibilidade de escolha entre o linux A e o linux B...

hoje em dia existem muito mais de 490 distribuições diferentes (e nascendo mais) o que torna muito chato para qualquer noob entender que um pacote A não vai servir de cara na distribuição B.[...]

Pryderi $\rightarrow$ crazies $\bullet 4$ anos atrás

Difícil acontecer. Os próprios linuxistas vivem discutindo entre si ferozmente na base do "minha distro tem um pinto maior que a sua".[...]

Fabião $\rightarrow$ P_Mares • 4 anos atrás

Eu chamei a atenção pra isso outrora, aproveito para chamar de novo.

[...]Não tapem o sol com a peneira: Você não usa mais "Linux", usa Ubuntu. Usa SuSE. Usa Fedora, Mandriva, DSL... 
A associação ao nome, "Linux", deriva do sistema completo. O que se chama de GNU/Linux. O kernel tanto faz, ninguém liga. E está na hora da comunidade aprender a conviver com isso.

As glórias não podem ser divididas se vocês querem que as maçãs podres sejam separadas.

Entende?

E pra humanidade, Linux é o sistema, e não a base dele. Tecnicamente pra você pode ser, mas pra efeitos práticos isso não existe.

P_Mares $\rightarrow$ Fabião $\bullet 4$ anos atrás

Eu acho que, se uma distro é muito ruim, ela não vai ser muito usada e, logo, não vai fazer muita diferença nos números.

Além do mais, como postaram ali embaixo, essas estatísticas não são confiáveis.[...]

Fabião $\rightarrow$ P_Mares $\bullet 4$ anos atrás

[...]O alcance real do Linux é MUITO pequeno. Irrisório. Insignificante. E não tende a mudar tão cedo.

$[\ldots]$

Rqbtvo $\rightarrow$ Juliano-Buettner 4 anos atrás

Juliano, pare de pegar no pé do quedaderider. Apesar da profissão maligna dele em editar um centro de usura, ele não é tão mal pessoa. Aqui no meiobit ele é um usuário exomplar.

quedaderider $\rightarrow$ Rqbtvo $\bullet 4$ anos atrás

$\mathrm{O}$ q se faz no meiobit, fica no meiobit... e eh relembrado sempre e pra sempre! :D[...]

Assim como a "ostentação de saberes", os debates se tornam artifícios para a demonstração de poder entre os(as) comentaristas. Ou seja, aquele(a) que "vence" um debate ganha destaque perante os(as) demais pelo fato de que conseguiu, com suas palavras e ideias, demonstrar domínio acerca do assunto principal do debate que, por sua vez, pode estar relacionado direta ou indiretamente ao post.

A questão do assunto estar relacionada direta ou indiretamente ao post, ou não ter ligação alguma com este, é um ponto importante para o debate. Ao instituir um desvio de assuntos, o(a) comentarista assume riscos: pode ser bem recepcionado(a) ou ser banido(a) e ser descreditado, tendo em vista que, diante da situação, ele(a) terá perdido o debate.

Os(as) comentaristas que entram nas discussões ou nos debates parecem tentar trazer alguma "luz" para os fatos expostos, dentro do assunto posto em xeque. Seja para moderar o debate, na tentativa de trazer a discussão para o tópico abordado no post, seja para complementar ou ponderar as ideias apresentadas anteriormente (no posts e em outros comentários). Quem consegue "encerrar" a discussão com um comentário que se torna inquestionável, direciona os holofotes para si, mesmo que a intenção não tenha sido explicitamente essa. Vencer um debate, nas seções de comentários dos blogs de Cardoso, significa expor ideias de maneira objetiva, clara e concisa, apresentando argumentos que sustentem o que foi apresentado. Na maioria dos casos, a opinião preserva a ideia do blogueiro, 
dando outros argumentos e apontamentos que arrematam, logicamente, o posicionamento assumido por Cardoso.

No momento que o assunto se distancia do tópico principal do post, o debate acaba por se tornar uma discussão direta entre comentaristas. Em alguns casos, a discussão surge porque os(as) envolvidos(as) brigaram anteriormente em outras ocasiões. Por conseguinte, os comentários torna-se uma forma para levar disputas pessoais adiante.

Os debates entre comentaristas nos revelaram a importância de demonstrar poder no circuito-Cardoso. Tal e qual em uma corte, com uma hierarquia de posições e interesses a serem preservados, percebemos como "vencer" um debate nas seções de comentários dos posts analisados é um objetivo buscado por comentaristas, especialmente aqueles(as) que se encontram na "corte de Cardoso". À medida que as participações em debates se tornam constantes, o(a) comentarista começa a construir a sua persona para aqueles ambientes e, ao mesmo tempo, pode fazer uso desse destaque para atrair público para seus próprios espaços digitais. Além da obtenção de credibilidade, legitimada pela autorização de Cardoso para tais performances.

\section{- $\quad$ Menção a Microcelebridades, Blogs elou outras Mídias}

A amplitude dos posts do Blog do Cardoso, do Contraditorium e do MeioBit pode ser comprovada por meio dos comentários feitos pelos(as) visitantes desses espaços. Quando Cardoso publica um post que atinge uma repercussão relativamente grande, seus(suas) comentaristas costumam citar, em suas participações, outros blogs/sites, outras mídias ou, ainda, outras microcelebridades que mencionaram o conteúdo em seus respectivos circuitos-blogue. Além disso, quando Cardoso é comparado com o estilo de outra microcelebridade, o blogueiro tem a sua performance legitimada, dando entendimento de que ele está no caminho certo para a manutenção de seu estrelato.

Post 1: Exclusivo: As fotos do acidente do vôo 1907 da Gol de dentro do avião, publicado no Blog do Cardoso em 26/10/2006 - 1.106 comentários

Rafael Slonik. 319 weeks ago

É de lost?

Você está virando um Cocadaboa.

[...]

Lorota 318 weeks ago 
Oi, Cardoso, eu de novo. Parabéns, ó:

http://www1.folha.uol.com.br/folha/cotidiano/ult9...

[...]

Roberto Lombardi. 318 weeks ago

Cara, muito bom...

E hoje saiu no Terra... hahahahaha

http://tecnologia.terra.com.br/interna/0,,OI1226023-EI4802,00.html

Post 2: $O$ que é pior: Matar 20 milhões de pessoas ou sacanear um pedaço de pão?, publicado no Blog do Cardoso em 15/01/2009 - 58 comentários

Edmundo Martins. 210 weeks ago

Por um instante eu achei que tava lendo o Morróida. =P [...]

Post 3: O Grande Post das Salsas Aéreas, publicado no Contraditorium em 04/06/2009 - 148 comentários

Verônica 189 semanas atrás

Muuuito bom!!! Confira também as teorias da @twittess, do Twitter...[...]

Fora do assunto, mas mais um fora:

"Passageiros do Avião da Air France eram CEOs, Políticos, príncipes e notáveishttp://migre.me/1IM8 Grandes perdas :("

>> Porque se não fossem bem-sucedidos, seriam perdas insignificantes!

E ainda tem mais de 41 mil seguidores...

$[\ldots]$

Luana 187 semanas atrás

[...]Tá... quero saber se posso linkar esse post no meu blog. Em caso positivo, como você gostaria que eu desse os créditos? Tem alguns blogueiros que fazem algumas exigências, nunca sei a forma correta de dar os créditos.

Cheguei aqui através do Templates Novo Blogger.

Abraço.

Post 4: Haiti - terra amaldiçoada por Deus, publicado no Contraditorium em 13/01/2010 - 133 comentários

Leonel. 151 semanas atrás

Conheci seu blog através do bobagento. Parabens pelo post, ele mostra para muitos o que era o Haiti.[...]

Post 5: Algo Misterioso Vai Acontecer, publicado no MeioBit em 28/04/2010 - 121 comentários

BobbyLabel $\bullet 3$ anos atrás

Ih ferrou.. a Globo contratou o pessoal do Meio Bit![...]

Post 6: O que é que tem dois polegares e está se lixando pra usuários Android?, publicado no MeioBit em 08/02/2011 - 126 comentários

webmaster $\rightarrow$ rafael $\bullet 2$ anos atrás

@rafael_, é uma boa opção se ela não se preocupar com atualizações, normalmente não geeks se importam menos com isso.

Ainda vi em um blog um artigo sobre os melhores aparelhos rodando Android por até 800 dilmetas, nem sei se posso por link de outro blog aqui, se não puder, por favor apaguem o comentário, mas ai vai:

http://www.mobizoo.com.br/inde...

O blog não é meu, nem conheço o dono.

Dos mostrados ali eu iria de HTC, chances maiores de atualização creio eu.

willytranquera $\rightarrow$ webmaster $\bullet 2$ anos atrás

@ webmaster, tudo bom?

O site/blog que você recomendou é meu. Obrigado pela indicação.

Tem um post novo lá sobre o novo Xperia X8, que também é uma excelente opção de compra. 
http://www.mobizoo.com.br/inde...

Grande abraço!

A citação de links em blogs de microcelebridades ou em sites de veículos de comunicação de massa demonstram a amplitude alcançada pelos posts de Cardoso. Ainda, ao ter um link de alguma postagem nesses sites, Cardoso legitima o seu sucesso com o reconhecimento por outras microcelebridades e por veículos de comunicação de massa.

Notamos, ainda, que em alguns casos ser comparado ou estar nesses blogs é uma forma de elogio, especialmente se o estilo de publicação e proposta é semelhante ao de Cardoso. Por outro lado, percebemos que se aproximar de veículos de comunicação de massa pode ser algo visto de forma negativa pelos(as) comentaristas. Essa aproximação seria, segundo esses indivíduos, uma forma de o blogueiro se submeter às ideias que orientam publicações em mídias de massa e, com isso, a sua "voz" ser suplantada por esses veículos.

Essas citações acabam por reforçar a rede de trocas existente no circuitoCardoso. Quando alguém "fora" desse circuito reconhece as publicações de Cardoso, notamos que se constrói uma credibilidade em torno de sua figura, ainda que esta fundamente-se em um estilo de performance peculiar. Especialmente se esse reconhecimento for feito por algum(a) famoso(a). Ou seja, existe uma série de elementos que legitimam o comportamento de Cardoso e permitem ao blogueiro manter suas ideias e sua performance. Por conseguinte, o poder simbólico do circuito-Cardoso cresce nos ambientes digitais.

Ser citado por outras mídias, por outras microcelebridades ou, ainda, ser comparado ao estilo destas é um privilégio que, certamente, aumenta o valor simbólico do circuito-blogue de uma personalidade como Cardoso. Ao receber essas menções, o blogueiro comprova sua popularidade e o seu alcance, assim como o sucesso de sua performance on-line. Por conseguinte, Cardoso legitima-se como uma microcelebridade e dono de um circuito-blogue com relativa visibilidade.

\section{- $\quad$ Participação de Microcelebridades}

Microcelebridades, como vimos, são indivíduos que, por meio de suas performances em ambientes digitais, se tornaram famosos. O sucesso dessas 
pessoas rende a elas destaque para o que publicam e, especialmente, para os blogs que indicam, frequentam e comentam. Logo no início de suas atividades, ainda no Blog do Cardoso, Cardoso conquistou uma proeza: recebeu visitas de diversas microcelebridades com as quais, aparentemente, havia estabelecido contatos prévios. A participação desses indivíduos, além de aumentar o número de visitantes, contribuiu para a construção do circuito-Cardoso e para a obtenção de credibilidade para o mesmo.

As participações de microcelebridades estão alinhadas à proposta dos blogs e, principalmente, às ideias inseridas por Cardoso em seus posts. Nesse sentido, as microcelebridades concordam com as opiniões do blogueiro, dando-lhe legitimidade para continuar publicando posts com a mesma qualidade.

Post 1: Ou dá ou desce, Bispo Macedo, publicado no Blog do Cardoso em 01/12/2005 - 1.181 comentários

Danilo. 317 weeks ago

vc é muito burro!!!!!!! sem visão de nada. vc vai acabar se convertendo, pode escrever o que eu digo. Deus sabe da nossa visão e do proposito com sua nação santa.

Cobra 317 weeks ago

Cardoso,

se você se converter, como o Danilo está dizendo que vai acontecer, pelo menos faça a conversão para total flex e não apenas Whisky. Variar é bom, tequila, chope, rum, vodka também são boas opções, por isso a sugestão da conversão Flex

Post 2: Exclusivo: As fotos do acidente do vôo 1907 da Gol de dentro do avião, publicado no Blog do Cardoso em 26/10/2006 - 1.106 comentários

Fabião. 319 weeks ago

HuAHuAHUhaUhAUhaUhaUhaUhAUhaU

pqp

AHuAHuahUA

cardosão, vc é maldoso cara! muito mal maldoso!

curti isso, ajudarei a disseminação!!

Post 3: Quem quer ver as fotos dos corpos do acidente da gol?, publicado no Contraditorium em 06/10/2006 - 826 comentários

Nospheratt. 323 semanas atrás

[...]É natural (e lamentável) que o mesmo comportamento exista na Internet - só que magnificado pela comodidade do anonimato.

Não entendi isso de "quando uma vida se perde com o propósito de entreter adolescentes". $\mathrm{O}$ acidente foi um acidente, e que eu saiba acidentes não tem propósitos; que usem isso para diversão é outra coisa. Ou você está se referindo a outra coisa?

Post 4: Perdendo a fé na humanidade, publicado no Contraditorium em 07/08/2007 - 67 comentários

Nick 279 semanas atrás

Fala aí, Pai Cardoso! Hehehe. Inacreditável, este tipo de comentário é tão absurdo que parece até piada, mas infelizmente não é... =)

Sobre a cerveja, eu até ia mandar servir uma pra vocês no púlpito, mas aí acabou o encontro. Fica pra próxima!!! 
Post 5: Blue me punto para Microsoft, publicado no MeioBit em 05/10/2007 - 68 comentários

\author{
Alexandre Fugita $\bullet 5$ anos atrás \\ Cardoso, \\ A definição de carro, creio eu, deve indicar que se trata de um veículo com rodas e que se \\ locomove por meio de um motor. O UNO tem rodas e motor. É um carro, portanto! :-) \\ obs: ei, o link para o Techbits está com um probleminha! De qualquer forma, valeu a \\ citação! \\ Post 6: Linux atinge a marca histórica de $1 \%$ do mercado, publicado no MeioBit \\ em 02/05/2009 - 303 comentários \\ fernandovalente $\bullet 4$ anos atrás \\ O dia que alguns usuários pararem de dizer que ele é dificil ele emplaca. Eu acho Ubuntu \\ mais fácil de usar que o Windows e essa não é uma opinião particular. \\ Juliano-Buettner $\rightarrow$ fernandovalente $\bullet 4$ anos atrás \\ É você o mesmo Fernando Valente da Sykey.net?[...] \\ fernandovalente $\rightarrow$ Juliano Buettner $\bullet 3$ anos atrás \\ Eu mesmo.
}

A participação de microcelebridades nos blogs de Cardoso, na forma de comentários, desde o início, contribuiu para que as publicações do blogueiro se tornassem conhecidas em ambientes digitais. Aliadas às técnicas de atrair público, a participação de uma microcelebridade é uma forma de reconhecimento, demonstrando que Cardoso estava apto a fazer parte do grupo, atuando como microcelebridade. Na medida em que microcelebridades reconhecem a qualidade dos posts de Cardoso e, em alguns casos, contribuem para a sua divulgação, o blogueiro ganha espaço - e público - para formar o seu circuito-blogue, no qual ele mesmo será o "mediador" e "legitimador" de microcelebridades em potencial.

O papel desempenhado pelas microcelebridades, neste caso, parece o de defender os posicionamentos de Cardoso e, ainda, servir como aconselhamento para que as suas performances sejam aprimoradas. Ao receber a atenção de outras microcelebridades, especialmente sob tais formas, Cardoso assume uma posição de destaque e adquire credibilidade para atuar como tal.

Em alguns casos, a participação da microcelebridade gera uma surpresa nos(as) comentaristas que, por sua vez, chegam a confirmar as suas identidades. Nesse instante, observamos que as microcelebridades participantes possuem estilos parecidos com o de Cardoso, assim como as temáticas abordadas em seus ambientes digitais são semelhantes àquelas vistas no Blog do Cardoso, no Contraditorium e no MeioBit. 


\section{- $\quad$ Cardoso também é Cortês}

Por se tratarem de blogs com um fluxo de comentários relativamente grande, o Blog do Cardoso, o Contraditorium e o MeioBit contam com poucas participações de Cardoso, especialmente no que concerne à resposta a um comentário. Ainda assim, essas poucas "aparições" se tornam interessantes, dado o comportamento de Cardoso de raramente responder comentários e, ainda, de a sua performance ser considerada por muitos(as) controversa. $\mathrm{Na}$ verdade, Cardoso não precisaria responder comentários, tendo em vista que a sua corte "trabalha" para dar inteligibilidade aos comentários de seu enunciador. Esse comportamento, de distanciar-se de suas audiências, dá um aspecto distanciado o qual legitima uma forma de poder atrelada à performance do blogueiro.

Post 1: Mini-Meme: 5 besteiras que me irritam, publicado no Blog do Cardoso em 01/04/2007 - 99 comentários

Simon. 315 weeks ago

Também sou evangélico e adimito que fiquei triste quando li o ítem 3 do meme, muito divertido por sinal. Repito: triste... porque deve haver alguma razão pra ele estar lá.

Mas acho sim que dava pra ter sido mais específico Cardoso, assim você falou de muita gente e acabou sendo de certa forma injusto. Como não acho que o rótulo serve pra mim não me senti ofendido, mas respeito a reação do companheiro que comentou acima e até acho que você também, apesar de tudo e ao contrário de alguns leitores que também comentaram.

Eu sei que o blog é seu, você faz dele o que quiser, que existe liberdade de expressão nesse país e todo esse blá blá blá... (sem querer menosprezar a conquista histórica) entendo, mas acho que a questão não é essa. Não falo de regras, leis, etiquetas... talvez de bom senso ou de respeito, essas coisas complicadas que costumam dar algum problema quando se tem muita gente num mesmo lugar já que cada um tem a sua cabeça, mas que geralmente também são a solução. É tudo meio subjetivo, mas na prática funciona, garanto.

Gostaría de dizer que pretendo continuar lendo o blog como sempre, já vi mais coisas boas do que ruins por aqui e tenho aproveitado o que acho que vale a pena. Alguns deveriam começar a fazer o mesmo.

Cardoso 315 weeks ago

Simon, uma minoria inteligente não representa o conjunto. Um de meus maiores amigos de infância era batista. Até de nome, João Batista. Não bebia, não fumava, não falava palavrão, e era um dos caras mais queridos da turma. Eu até ajudei a dar o nome pro jornalzinho da igreja dele, o "Mixto Crente".

Ele NUNCA tentou me converter, NUNCA encheu o saco de ninguém reclamando das besteiras que fazíamos.

Só que ele, como você, são uma minoria absoluta. Por melhores que sejam (e veja só, você não citou passagens bíblicas, não ESCREVEU TUDO EM CAIXA ALTA e leu o post todo, isso não condiz com o evangélico-padrão que cai aqui) vocês não podem justificar o coletivo.[...]

Há ovelhas ruins demais para o rebanho ter bom nome.

Post 2: Responda rápido: Isso aconteceria na Suécia?, publicado no Blog do Cardoso em 27/1 1/2008 - 99 comentários

tássia lagos e sucre. 210 weeks ago

mais ou menos. eu morava proxima de nova orleans quando o furacao katrina chegou em agosto/2005 (eu estava a 2 horas de nova orleans, perto o bastante para sofrer com os ventos fortissimos do dito cujo)--pra quem nao lembra o katrina afundou nova orleans. 
bem, a cidade aonde eu vivia ficou sem luz, agua e gasolina por muitos dias. muitas-muitas-- arvores cairam nas ruas, quintais; muitas casas perderam telhas ou telhados inteiros. os dois pinheiros altissimos do meu quintal quebraram e cairam em cima da cerca. depois de tentar por + de um mes alguem pra cortar e remover os dois, consegui um sujeito que cobrou um absurdo pelo servico. e olha que ele fez um preco razoavel comparado com os outros, que nao apenas estavam super ocupados cortando arvores do resto da cidade mas tambem estavam cobrando os olhos da cara so por causa da demanda (ouvi exatamente isso dos profissionais que contactei).

[...]conclusao: e da natureza de certos humanos se aproveitar das desgracas alheias. gente ruim tem em tudo quanto e pais. e gente boa tambem.

Cardoso. 210 weeks ago

Tati, Katrina não conta. NO é uma região bem mais próxima do Brasil do que de Toronto, inclusive há a famosa foto do saqueador de cerveja do Katrina.

Post 3: Controle de zoonoses não protege o seu bichinho - eu adorei, publicado no Contraditorium em 13/01/2009 - 160 comentários

RobertoKCA. 209 semanas atrás

[...]Sou da crença de que vc deveria ter "cagado" o piá com uma ameaça, e mais ainda à mãe dele, mas nunca agredir a criança, que também é menor e indefesa. Um discurso no estilo "se tua mãe não te dá modos, eu dou" já seria o suficiente.

Cardoso. 209 semanas atrás

Uma criança que dá tapa na cara da mãe (EU VI!) não reage a ameaças.

Post 4: Ao contrário de Ayrton Senna a F1 está morta e enterrada, publicado no Contraditorium em 2010 - 69 comentários

Caloã 110 semanas atrás

A corrida de Donnington Park foi 1993, só para corrigir.[2]

:)

83 nem tinha shumi ainda! :P

Cardoso. 110 semanas atrás

Eu li errado :(

Post 5: Brasil e Moçambique vão cooperar no desenvolvimento científico, publicado no MeioBit em 25/11/2008 - 396 comentários

Mario Gentil $\bullet 4$ anos atrás

A matéria fala apenas de um acordo bilateral de cooperação. Nâo diz que não há ou haverá outros acordos bilaterais, ou que a cooperação com Moçambique é prioritária em relação a qualquer outra.

Infelizmente, o autor do post se deixou levar pela paixão político-partidária ao escrevê-lo.

Este blog é ótimo quando se atém objetivamente a questões tecnológicas.[...]

Carlos Cardoso $\rightarrow$ Mario Gentil $\bullet 4$ anos atrás

Mesmo que a cooperação custasse $\mathrm{R} \$ 10,00$ já seria dinheiro jogado fora, e o acordo é ruim independente do governo que o fechou, embora populismo terceiro-mundista seja especialista dos petralhas...

Post 6: Para Carl, publicado no MeioBit em 09/11/2010 - 143 comentários

tramkpqoiesmakl8982jmsn992 2 anos atrás

Bem, nunca me manifesto no Meio-Bit por ter que logar para comentar. Mas dessa vez preciso defender uma visão de mundo aqui.

[...]O que não teve proveito foi o preconceito, incitado por vários amigos leitores que comentaram, contra aqueles que se declaram contrários à visão de mundo do Sagan, se achando auto-confiantes demais, baseados não em seu próprio poder argumentativo, mas sim nos trabalhos de Sagan e, porque não, no de Cardoso. Chamar cristãos de "biblionautas" e "salsa-cristãos" é trazer uma inquisição pessoal, social e verbal nesse pequeno mundo dos comentários, repetindo a idade medieval num universo reduzido e falsamente lógico-científico.

Os argumentos deles, Sagan e Cardoso, realmente são fortes e dificilmente refutáveis. Mas tudo é uma questão de "cosmovisão", ou seja, visão do cosmos. Não o Cosmos do Sagan, mas o conceito de "mundo" (ou universo), com tudo aquilo que nele contém. 
[...]E afirmo com veêmencia que é dogma, até porque não vi ninguém questionando o próprio Sagan, deixando assim de exercer a posição de "ter medo de questionar, e jamais aceitar dogmas" que o próprio Sagan pregava, segundo o Cardoso. Estamos realmente sendo curiosos o bastante? Quis quaestionem ipsos quaerentium? Quem questionará os questionadores?

Então, espero que os amigos, assim como o Cardoso e o Sagan, mantenham-se humildes em suas posições, não pensando que são os donos da lógica, mas que são simplesmente um infinitésimo de matéria no cosmos ao qual foi dado o privilégio de desenvolver um pensamento elaborado.

Abaixo o misticismo científico!

Carlos Cardoso $\rightarrow$ tramkpqoiesmak18982jmsn992 2 anos atrás

[...]Ninguém aqui precisa questionar Sagan pois SAGAN questionou Sagan, na Edição de 10 Anos de Cosmos ele mostrou vários pontos da série original que foram refutados, aprimorados ou simplesmente superados.

De resto se eu partir do princípio que o Mundo surgiu das lágrimas do Grande Juju do Lago Negro isso não torna minha hipótese digna de credibilidade ou equivalente a uma teoria cosmológica de verdade.

As respostas dadas por Cardoso, em algumas ocasiões, são complementares e não agridem o(a) comentarista. Dos dados analisados, isso ocorre quando o blogueiro responde a um comentário de alguma microcelebridade, de alguém próximo (parte de sua corte, por exemplo) ou algum comentário que complemente, dentro de suas ideias, o assunto abordado no post.

Por se tratar de uma manifestação escrita, o comentário, quando agressivo, costuma contar com elementos que caracterize a revolta contra o posicionamento "acima do bem e do mal" por parte tanto de Cardoso quanto de seus(suas) comentaristas. Uma das formas de manifestar isso é por meio de caixa alta, palavrões e xingamentos diretos. Quando não se encontra nenhuma dessas características, podemos dizer que se trata de uma resposta "normal" a um comentário que contém elementos que expressem a opinião do(a) comentarista para aquele ambiente (seção de comentários).

Em alguns momentos, notamos o reconhecimento, por parte de Cardoso, de erros cometidos durante as postagens. O blogueiro assume a "falta de atenção" e aceita a sugestão do(a) comentarista. Poderíamos dizer que esse comportamento é adotado quando o(a) comentarista em questão é alguém que possui um histórico positivo com Cardoso ou que faz parte de sua corte. O histórico positivo diz respeito ao fato de que o(a) comentarista não é considerado(a) um(a) troll, um(a) tard ou um(a) salsinha. Por essa razão, ele(a) é aceito(a), assim como as sugestões para correções do post. Entretanto, a menos que essa correção seja considerada relevante por Cardoso, ela será aceita e, consequentemente, o(a) comentarista continuará com um histórico positivo no circuito-Cardoso. 


\section{- $\quad$ Cardoso lidando com suas Audiências}

Lidar com audiências, na blogosfera, pode definir o sucesso ou o fracasso de um blog. Na tentativa de conquistar fãs, o(a) blogueiro(a) pode omitir críticas, autorizando apenas comentários elogiosos e amigáveis. No caso de Cardoso, notamos que o blogueiro costuma autorizar comentários elogiosos e críticos, de membros(as) da corte ou forasteiros(as). As únicas restrições observadas parecem ser quanto a participações seguidas do(a) mesmo(a) comentarista ou de SPAM's. No primeiro caso, quando um(a) comentarista tenta postar diversos comentários, mudando apenas o nome, mas mantendo a crítica, Cardoso tem o hábito de fazer uma espécie de denúncia nas seções de comentários. Em uma tentativa de justificar o bloqueio, Cardoso divulga o endereço de $\mathrm{IP}^{32}$, como forma de comprovar que a pessoa em questão está agindo contra as regras da boa convivência entre os(as) comentaristas.

Geralmente, o blogueiro lida com suas audiências de forma totalitária. $\mathrm{Ou}$ seja, o seu pensamento sempre irá prevalecer e, quando houver alguma resposta de Cardoso com relação a algum comentário, a probabilidade de ser ríspida é relativamente grande. Essa forma de comportamento acaba por caracterizar a performance do blogueiro, contribuindo para ampliar a sua fama de "sabe tudo" e de alguém que não gosta de ser contrariado. Em nosso entendimento, Cardoso parece gostar dessa fama negativa, pois ajuda na composição de sua persona digital.

Post 1: Exclusivo: As fotos do acidente do vôo 1907 da Gol de dentro do avião, publicado no Blog do Cardoso em 26/10/2006 - 1.106 comentários

Atenção. 324 weeks ago

Caro Amigo

Apenas um recado de uma pessoa prudente.

Você pode se dar muito mal com essas fotos e passar o resto dos seu dias numa cadeia.

Acaba com essa página antes que isso aconteça.

Cardoso 324 weeks ago

Claro que posso, é crime hediondo subestimar a inteligência de carniceiros como você que vêm aqui atrás de fotos de cadáveres, $M r$ : 200.101.73.181, 200-101-73181.bsace204.dial.brasiltelecom.net.br.

$[\ldots]$ adriano monteiro sant. 324 weeks ago

mentiras desse tipo não deveria sair na internet. o ministerio publico deve verificar esses atos criminais. (adriano monteiro tobias barreto-se

${ }^{32}$ IP é uma sigla para Internet Protocol, que indica o código recebido pelo computador de um indivíduo ao acessar a rede Internet. 
$[\ldots]$

Cardoso 324 weeks ago

Adriano monteiro sant - Você é jornalista, fez um curso superior, segundo grau pelo menos? Como você erra uma concordância SIMPLES como "mentiras desse tipo não deveria"?

Quanto ao fato de você achar que o Ministério Público deveria me punir, remover o site, etc, o quê a ABI diz de um RADIALISTA que propõe ABERTAMENTE uma ação de CENSURA? Qual o email da Comissão de Ética da Associação de Radialistas de Segipe?

Post 2: O que é pior? Matar 20 milhões de pessoas ou sacanear um pedaço de pão?, publicado no Blog do Cardoso em 15/01/2009 - 58 comentários

Daniel Siqueira. 209 weeks ago

Cardoso, como já foi dito aqui em cima, a hóstia representa o corpo de Cristo para os Católicos. E você não quer que um cara que já foi crucificado porque disse que as pessoas poderiam ser legais umas com as outras ainda por cima corra o risco de contrair uma hipertensão, quer?

Cardoso. 209 weeks ago

Poderia representar até os sagrados pelos pubianos da Luciana Vendramini. Sacanear uma hóstia ser mais sério que cometer genocídio é DOENTIO.

Barba. 209 weeks ago

Isso é fácil de explicar:

A hóstia NÃO É um pedaço de pão. Ela representa o corpo do judeu frankenstein do calendário.

Da mesma maneira, os genocidados NÃO SÃO vítimas. Eles representam algo menos importante do que um mero pedaço de não-é-pão.

Simples assim.

Cardoso 208 weeks ago

clap clap clap clap

Lucas. 202 weeks ago

O problema é que voces não entendem uma coisa elementar. $O$ valor considerado não é o objeto em si, um pedaço de pão, é o que este objeto representa.

Para os católicos, este objeto representa Cristo, Filho de Deus. Portanto, o desrespeito refere-se a quem o objeto representa. Para quem não é católico, este pedaço de pão não representa nada, portanto, desrespeitá-lo só fará diferença se após a morte o indivíduo descobrir que Deus existe.[...]

Post 3: Quem quer ver as fotos dos corpos do acidente da gol?, publicado no Contraditorium em 06/10/2006 - 826 comentários

Cláudio Tomás. 328 semanas atrás

[...]Cara, você não tem interesse nas fotos dos mortos ? Tudo bem.

Mas metade do mundo tem. Eu tenho, no meu trabalho, se eu as tivesse aqui agora, em um album, TODOS iriam querer ver ...

$\mathrm{Na}$ rua, as pessoas iriam querer ver. Todo mundo quer ver.

Você provavelmente, nunca deve ter visto um cachorro rolando na carniça e se divertindo com isso.

Cardoso 328 semanas atrás

"Você provavelmente, nunca deve ter visto um cachorro rolando na carniça e se divertindo com isso."

Excelente definição para quem gosta desse tipo de foto...

Post 4: Por favor, não matem os meus heróis, publicado no Contraditorium em 25/01/2011 - 105 comentários

Mário José Serran. 98 semanas atrás

Cardoso: eu li este post de boca aberta e cheguei a me babar.

Que coisa linda você escreveu ao pé da foto de Kirk e Spock!

[...]Nos idos de 1974, minhas viagens levaram-me à Grecia, e, acompanhado de uma bela guia, visitei o Passo da Termôpilas, onde está o monumento ao Grande Rei Leônidas e seus 300 Heróis Espartanos.

Estive alí, lembrando dos meus livros de escola, em que tinha lido essa Epopéia. 
Cheguei a me emocionar. Como me emociono hoje, em 2011 quando revejo o filme cujos atores nem eram nascidos em 1974.

Quando voltei a mím, já era noite.

É isso.

Vida Longa e próspera!

Cardoso. 98 semanas atrás

Eu te invejo.

Post 5: 10 hábitos que nenhum micreiro se lembra mais, publicado no MeioBit em 03/12/2008 - 263 comentários

Zippy $\bullet 4$ anos atrás

Putz, eu vou ter que chutar o balde...

Alguém é da época de ter um disco de sistema e um disco de trabalho ? Tinha que ficar trocando os dois quando tu não tinha a BENÇÃO de ter dois drives de disco no computador.

E da revista Micro Sistemas ?[...]

Carlos Cardoso $\rightarrow$ Zippy $\bullet 4$ anos atrás

Eu tive ARTIGOS publicados na Micro Sistemas, e sou amigo do Divino Leitão.

Ziggi -> Carlos Cardoso $\bullet 4$ anos atrás

[modo sarcástico completamente desligado]

Estou impressionado :jawdrop:

[modo sarcástico ainda desligado]

Depois dessa revista demorou muito até que eu tivesse acesso (leia-se internet) a algum conteúdo técnico do nível que tinha nessa revista. A última que eu tive foi uma edição sobre o 1o. filme feito completamente em um computador: Cassiopea. Feito aqui no Brasil. O Toy Story saiu um pouco antes mas parece que eles scanearam umas texturas.

Post 6: Engadget declara Guerra aos Trolls, publicado no MeioBit em 02/02/2010 - 303 comentários

guslimarj $\bullet 3$ anos atrás

Os Trolls são realmente um problema. Mas um problema ainda maior, é confundir trollagem com opinião. Tudo bem que nem todos sabem expor suas opiniões, mas não se pode considerar este tipo de pessoa um troll.

Carlos Cardoso $\rightarrow$ guslimarj $\bullet 3$ anos atrás

Opinião sem justificativa não passa de trollagem.

leandroalone $\rightarrow$ guslimarj $\bullet \underline{3 \text { anos atrás }}$

A pior confusão entre opinião e trollagem pura e simples as vezes não é com "o que" é dito, mas "como". Ainda sim trolls só servem pra encher o saco

Carlos Cardoso $\rightarrow$ leandroalone $\bullet 3$ anos atrás

Pessoal não entende que "merda de texto" NÃO é opinião. [...]

Emanuel Laguna $\bullet 3$ anos atrás

Se é para abrir o jogo, literalmente falando, admito que já fui um Sonysta $<$ small $>$ (para quem não entender, é algo como um *tard que defende cegamente os consoles Playstation) $<$ /small $>$, mas, com o passar dos anos, fui reconhecendo a importância que a Nintendo teve na indústria dos jogos eletrônicos. <img alt="8)" class="smiley-class smileysProcessed" s[...]

Pena que muitos trolls acabam colocando os videogames <small>(o 'alvo' preferido dos trolls é a Nintendo) $<$ /small $>$ como "coisas de criança", algo semelhante a achar que a Apple só fariahardware e software voltado ao público homossexual < small >(nada contra tal público ou contra a Apple, apenas faço essa analogia para uma melhor compreensão da cultura gamer $)</$ small $>$. [...]

Carlos Cardoso $\rightarrow$ Emanuel Laguna $\bullet 3$ anos atrás

Troll de console é complicado, os de sistema operacional são mais tranquilos, mas os de fotografia são complicados.[...]

tatakoto_BR • 3 anos atrás

Assuntos polêmicos atraem trolls além de usuários mais bem comportados, e audiência é lucro não?

Tbm é complicado diferenciar uma opinião mais acalorada de uma trollagem.

Carlos Cardoso $\rightarrow$ tatakoto_BR $\bullet 3$ anos atrás 
Grande engano. A maioria dos usuários detesta trolls. Não acha graça em gente perdendo tempo com brigas. Me mostre UM SITE que seja respeitado e esteja lotado de trolls.[...]

Diablobul $\bullet 3$ anos atrás

acho que o entendimento é simples:

estás na minha casa? Siga minhas regras.

Não gostou? Tem um "X" no canto superior direito da tela que vai resolver de uma vez seus problemas.

Insiste em ficar e tumultuar? Banido.

Agora fechar os comentários por causa de vandalismo virtual pra mim é ceder à pressão exercida pelos vândalos, aposto que eles devem estar se vangloriando em algum forum por 'terem fechado' os comentários do Engadget. Não resolve nada, e quando os comments forem reabertos eles voltarão mais sedentos por tumulto. Recuar nesses casos só dá sensação de vitória aos baderneiros.

Abcs

Cassiano Menezes $\rightarrow$ Diablobul $\bullet 3$ anos atrás

Concordo $100 \%$.

Carlos Cardoso $\rightarrow$ Cassiano Menezes $\bullet 3$ anos atrás

Concordo $100 \% . / /[2]$

Nos momentos em que se manifesta, por meio de comentários, Cardoso adota duas posturas: a do ditador das regras e bons costumes de seus blogs; e a do político que lida com a sua corte, sempre disposta a concordar e "debater" suas opiniões. Esta última nos mostra aspectos interessantes relacionados à postura do blogueiro quando assume um comportamento mais solícito. Essa "abertura" acontece também quando alguém apresenta uma opinião, referências ou piadas que, dentro do ponto de vista de Cardoso, são tão boas quanto as dele. Por essa razão, ele concede um momento de sua "preciosa" atenção na forma de comentários.

Alguns posts dos blogs de Cardoso recebem centenas de comentários que são atualizados em uma velocidade relativamente alta, especialmente se estes posts abordarem assuntos considerados polêmicos no âmbito dos respectivos blogs $($ Blog do Cardoso = religião; Contraditorium $=$ técnicas para aumentar audiências; MeioBit = sistemas operacionais). Nesse sentido, logicamente, seria impossível para o blogueiro responder a todos comentários, mesmo daqueles(as) que fazem parte de sua corte.

Os comentários são moderados por Cardoso em todos os blogs, por essa razão, no instante em que libera essas publicações, o blogueiro pode vir a perceber manifestações que, na sua opinião, são interessantes. Por conseguinte, elogia, complementa ou expõe elementos que interferiram na elaboração do post. 
Cardoso costuma criticar abertamente as pessoas que não conseguem sustentar suas próprias opiniões por meio de argumentos. Na visão do blogueiro, caso alguém discorde dele, deve apresentar as razões pelas quais o ponto de vista de Cardoso não pode ser aceitável. Assim, esta pessoa ganharia, de certa forma, alguma credibilidade e, consequentemente, não seria criticada abertamente pelo blogueiro e por sua corte. Embora essas manifestações sejam raras, alguns(mas) comentaristas conseguem expor suas opiniões - mesmo que parcialmente contrárias as de Cardoso - e entrarem para sua corte.

Na seção "Quem sou eu" do Blog do Cardoso (com links em seus outros blogs), Cardoso demonstra que gerenciará seus blogs como se fosse uma ditadura, no sentido de reprimir comentários que o blogueiro considere "idiotas", com pouco embasamento. Assim, quando observamos a maneira com que lida com suas audiências, especialmente quando lhes dá atenção, Cardoso revela os pressupostos que orientam as diretrizes de gerenciamento tanto de sua persona digital quanto da imagem de seus blogs. Nesse sentido, quando concede um momento de sua atenção, Cardoso parece demonstrar estima e apreço por determinados estilos de comentários, revelando, ainda que implicitamente, como deseja que os(as) comentaristas se comportem nesses ambientes. Portanto, uma vez que Cardoso conceda a sua atenção a um(a) novato(a) ou membro(a) da plebe, este(a) acaba por se tornar referência, mesmo que seja somente para aquele post. Ou seja, o estilo de comentar será copiado com o intuito de receber atenção do blogueiro/microcelebridade e, assim, conquistar espaço para divulgar suas páginas pessoais.

\section{- $\quad$ Ganhando e Perdendo Leitores(as)}

A quantidade de polêmicas gerada por é observada no volume de comentaristas que mencionam deixar de acompanhar seus blogs, por conta da postura do blogueiro. Entretanto, por outro lado, tais posicionamentos acabam por atrair e manter leitores(as) interessados(as) em acompanhar os posts recheados de assuntos controversos e referências sutis. Ganhar e perder leitores(as) faz parte das estratégias de Cardoso para gerar visitação para seus blogs ao mesmo tempo em que atrai pessoas que têm uma visão de mundo parecida com a sua e, por conseguinte, se interessam pelas mesmas coisas que o blogueiro. Por essa razão, 
Cardoso não parece estar muito preocupado quando perde um(a) leitor(a), pois, segundo o próprio blogueiro, ele deverá ter conquistado um(a) fã.

Post 1: Quem quer ver as fotos dos corpos do acidente da gol?, publicado no Contraditorium em 06/10/2006 - 826 comentários

UrUbu· 323 semanas atrás

Quando um blogueiro pensa mais no seu bolso do que na qualidade dos posts, retiro ele dos favoritos.

[...]Gostava do teu blog.

Deve ter atraído muito tráfego né. Oportunista.

Post 2: Haiti - terra amaldiçoada por Deus, publicado no Contraditorium em 2010 - 13/01/2010 - 133 comentários

Gabriel. 151 semanas atrás

Geralmente nos posts que geram comentários como "perdeu um leitor" as pessoas acabam ganhando um leitor freqüente: eu, rs... foi num post assim que eu conheci o site controle remoto, por exemplo (http://controleremoto.tv/blog/2009/10/mamae-ela-mechamou-de-bobao/) e num post assim que eu conheci esse site aqui - créditos para o bobagento...

[...]Por isso repito: ganhou um leitor...

Por sinal, teu texto "Fadas Não Mais Safadas" é ótimo...

Post 3: GVT anuncia GVT TV e miraculosamente foge do mais do mesmo, publicado no MeioBit em 16/09/2011 - 295 comentários

Douglas João Magalhães • um ano atrás

OLÁ, Juro que não conhecia seu blog, opa, agora vi lá no endereço, já tinha visto sim, mas não prestei atenção como devia ter feito!

Então, primeiramente, adorei seu texto! não só o texto escrito mas as coisas em volta dele tb! gostei mesmo![...]

Ganhar e perder leitores(as) faz parte de um circuito-blogue, especialmente quando este apresenta mudanças com as quais estes indivíduos deixam de concordar. A postura de Cardoso parece ter mudado muito pouco desde o início de suas performances on-line e da conquista de popularidade de sua persona digital. A reviravolta foi a realização de práticas que, antes, eram somente mencionadas por Cardoso em suas performances. Ou seja, a partir do momento em que se nota o uso de táticas para aumentar audiências e atrair, por conseguinte, um público heterogêneo, alguns(mas) comentaristas se ressentem da postura de Cardoso e deixam de acompanhá-lo. Em contrapartida, à medida que a fama do blogueiro aumenta, outros indivíduos manifestam um posicionamento favorável à postura adotada por Cardoso para os blogs em análise.

Justamente pelo estilo peculiar de Cardoso de blogar, os(as) leitores(as) se afastam e se aproximam dos ambientes em exame. A persona digital de Cardoso é 
dotada de performances que caracterizam a dinâmica dos blogs em questão, além de imprimir uma identidade cara ao blogueiro.

Aparentemente, o fluxo de audiências compensa a perda de leitores(as) como podemos perceber nos comentários analisados. Segundo Cardoso, os(as) leitores(as) que deixam de acompanhá-lo não são importantes, tendo em vista que, para ser um(a) seguidor(as) seu, é preciso concordar e interpretar positivamente seus pontos de vista e sua performance. Assim, uma vez que alguém discorde da postura de Cardoso, esta pessoa não faz parte de seu público-alvo e nunca será um(a) seguidor(a).

Em contrapartida, as manifestações de novos(as) leitores - e potenciais seguidores(as) - costumam avaliar positivamente as performances de Cardoso usando argumentos parecidos com aqueles usados por comentaristas que expressaram repúdio às atitudes do blogueiro. Nesse sentido, os elementos que atraem e afastam os(as) leitores(as) são os mesmos para críticos e fãs.

Com base nisso, podemos depreender que a performance de Cardoso atinge duas parcelas de públicos. Em um primeiro instante, as audiências são heterogêneas: aqueles(as) que discordam totalmente dos posicionamentos assumidos pelo blogueiro não pretendem acompanhá-lo. Os(as) demais tornam-se seguidores(as) em potencial, podendo compor a "corte de Cardoso". Assim, em posts que Cardoso assume posturas que podem ser consideradas antiéticas, alguns(mas) desses(as) seguidores(as) em potencial deixam de seguir o blogueiro. Por fim, o grupo que fica forma o público-alvo do blogueiro e, por conseguinte, constitui sua audiência principal.

$* * * * * *$

Cardoso sabe a importância que a participação de outras pessoas têm para a legitimação de sua condição de microcelebridade. Os comentários contribuem para que as ideias e opiniões do blogueiro sejam difundidas e reconhecidas por indivíduos fora do circuito-Cardoso. Por essa razão, notamos o interesse de Cardoso em motivar debates e participações para que seus posicionamentos venham a ser debatidos sob a interpretação de seus(suas) comentaristas. Logo, o volume de comentários gerado em seus blogs caracteriza que a sua popularidade encontra-se legitimada.

No circuito-Cardoso, o conhecimento funciona como uma credencial para revelar a aptidão de um(a) comentarista. Assim como a interpretação dentro dos 
parâmetros e diretrizes estabelecidos por Cardoso e legitimados por sua "corte", os saberes demonstram se o(a) comentarista estaria apto(a) ou não a fazer parte do grupo e, futuramente, conquistar um lugar na "corte de Cardoso".

Igualmente, a participação de microcelebridades e a menção do nome de Cardoso em outras mídias digitais ${ }^{33}$ revelam o reconhecimento da posição de destaque do blogueiro, assim como a relevância que ele tem para esses indivíduos e para esses dispositivos. Ser mencionado por pessoas e por mídias de massa garante a Cardoso legitimidade para sua "fala", valorizando a condição "inquestionável” de seu discurso.

Cardoso tem noção da importância de sua audiência para a manutenção de seu status na blogosfera. Por esse motivo, o blogueiro demonstra um cuidado maior em manter o mínimo de coerência em suas performances e interações online para que essa legitimidade não venha a ser questionada. Assim, percebemos que o blogueiro adapta as atuações de sua persona digital para que a impressão desejada seja alcançada e, com isso, o lugar de sua "fala" seja reforçado.

$$
* * * * * *
$$

$\mathrm{Na}$ próxima unidade, apresentaremos considerações acerca da análise realizada por esse trabalho. O material estudado revelou aspectos importantes sobre práticas sociais realizadas no âmbito do circuito-Cardoso, bem como a legitimidade do blogueiro como microcelebridade. Nesse sentido, a nossa observação buscou preservar a interdependência dessas práticas sociais para que fosse possível retratar a dinâmica performática e interacional desses ambientes.

${ }^{33}$ Cardoso teve alguns posts "linkados" pelo Portal Terra (http://www.terra.com.br) e pela Folha de S. Paulo (http://www.folha.com.br). 


\section{Considerações Finais}

De que adianta ter um blog se ninguém vai visitá-lo ou deixa comentários? Essa pergunta parece fazer parte da rotina de blogueiros(as) iniciantes. Disso podemos concluir que a própria existência de seus blogs está condicionada ao reconhecimento público, contabilizado por meio do número de acessos a esses espaços. Ao criar um blog, blogueiros(as) iniciantes se deparam com a necessidade de atrair pessoas e, assim, formar a "audiência" para esses espaços. $\mathrm{O}$ sonho de se tornar famoso(a) na Web coroa esse intento e a principal referência para essa notoriedade é a microcelebridade, cuja popularidade foi construída a partir de performances em ambientes digitais.

As microcelebridades são os indivíduos que conseguiram transformar suas performances e interações em determinantes da fama conquistada em ambientes digitais (BRAGA, A. 2008a). Por essa razão, são valorizados e respeitados justamente por terem construído uma persona digital de sucesso. $\mathrm{Na}$ busca pela notoriedade on-line vale a pena revestir-se de uma personalidade que agradaria a um público em potencial e, portanto, seria suscetível de conquistar visitantes para os ambientes digitais nos quais esses blogueiros(as) atuam. Para isso, esses indivíduos lançam mão de algumas estratégias, tais como: publicar links em listas de e-mails, fóruns de discussão e comunidades on-line; fazer comentários em blogs de microcelebridades, aproveitando a oportunidade para divulgar o próprio blog e, consequentemente, reunir uma possível audiência para seus posts.

Entretanto, conquistar um público revela-se uma tarefa árdua, especialmente para aqueles(as) com pouca experiência e sem "padrinhos"/“madrinhas" na blogosfera. Esses protetores(as) podem ser microcelebridades, como acontece no caso de Cardoso que, por conhecerem o(a) blogueiro(a), facilitam a divulgação e recomendam esses espaços para seu público. A partir daí, a pavimentação para o sucesso e a popularidade on-line tornam-se processos relativamente fáceis. Por outro lado, a persona digital precisa assumir posicionamentos que revelem características capazes de atrair e manter visitantes e, assim, construir um grupo 
em torno dessa personalidade. À medida que o sucesso é legitimado, o circuitoblogue dessa microcelebridade adquire valor simbólico e, consequentemente, atrai mais indivíduos interessados em acompanhar as produções do(a) blogueiro(a) em questão.

Um dos objetivos mais procurados por blogueiros(as) consiste na geração de comentários que, por sua vez, são uma forma de expressar interesse pelos posts publicados em um blog. As seções de comentários são espaços interacionais e propícios a performances, estabelecendo a existência de hierarquias e valores simbólicos em ambientes digitais, assim como uma cultura caracterizadora de uma noção de grupo para os indivíduos que interagem nesses espaços. Nesse sentido, percebemos práticas sociais revestidas de discursos legitimadores de posições, valores e papéis desempenhados nesses ambientes. Tais elementos emergem como parte de uma "mediatização" (BRAGA, J.L., 2006) e de diversas interações nas quais é possível identificar uma série de "ações conjuntas" (BLUMER, 1998) emblemáticas para o âmbito do Blog do Cardoso, do Contraditorium e do MeioBit.

Dessa forma, ao identificarmos a existência de um grupo heterogêneo, formado por defensores(as) e críticos(as) de Cardoso, passamos a conhecer a dinâmica interacional e performática cara aos blogs analisados. Essa dicotomia caracteriza as performances e as interações de todos(as) os(as) envolvidos, assim como a do próprio Cardoso. Nesse sentido, as "vozes" dos(as) comentaristas atuam de forma a legitimar a posição de Cardoso, assim como para reforçar o discurso do blogueiro no circuito-Cardoso.

Cardoso tornou-se um blogueiro de visibilidade por meio da legitimação de outras microcelebridades, de sua performance on-line e de seu público. O circuitoCardoso gerado em torno de sua figura chamou nossa atenção e, por esse motivo, acabou por se revelar um objeto de estudo interessante, especialmente se considerarmos as práticas sociais observadas nos blogs e posts analisados. Com isso, identificamos elementos utilizados por Cardoso na construção de sua persona digital e como essa persona é legitimada por meio dos comentários de seus(suas) comentaristas. Além disso, com o objetivo de verificar os modos pelos quais Cardoso tenta chamar atenção para seus blogs, observamos elementos usados pelo blogueiro para divulgação e estímulo de comentários. 
A dinâmica interacional e performática das seções de comentários estudadas revelou, ainda, uma noção de grupo organizada tacitamente pelos(as) próprios(as) comentaristas. Essa ideia de "comunidade" foi notada nos padrões de atuação, linguagens e gírias caras àqueles ambientes digitais. Além disso, o comportamento de alguns(mas) comentaristas, ao segregar os(as) forasteiros(as) ${ }^{34}$, caracteriza a preservação de um contexto interessante a todos(as) aqueles(as) que concordam e estão abertos(as) ao discurso de Cardoso.

Carlos Cardoso pode ser considerado uma microcelebridade por reunir uma "corte" de seguidores(as), assim como possuir legitimidade diante de outras microcelebridades e na Web. O circuito-Cardoso é bastante valorizado, tendo em vista que o blogueiro consegue atrair um número relativamente grande de visitantes para seus blogs, como vimos no caso dos dados em análise. Cardoso assume uma postura de "mediador", consentindo espaços limitados para as performances de seus(suas) comentaristas, assim como para a composição de uma hierarquia simbólica entre estes(as) participantes. Nesse sentido, o circuitoCardoso reúne características que identificam tanto a sua performance como o público ao qual o blogueiro se dirige.

O sucesso obtido por meio de interações e de performances em ambientes digitais é conquistado por meio de trocas entre pessoas que, por sua vez, acabam por frequentar os mesmos ambientes digitais. Dessa forma, podemos dizer que as microcelebridades que reconhecem o valor simbólico de Cardoso possuem circuitos-blogue semelhantes ao do blogueiro, seja pela temática e/ou pela performance. Ou seja, as microcelebridades que participam das seções de comentários de Cardoso reconhecem a sua postura ou, ainda, estão familiarizadas com as temáticas abordadas nos blogs em questão e gozam de prestígio nesses circuitos. Ou seja, além de uma posição importante em seus próprios circuitosblogue, essas microcelebridades também são respeitadas no circuito-Cardoso.

No âmbito da blogosfera, como podemos perceber nos comentários analisados, assumir o uso de técnicas para aumentar o número de visitantes de blogs é considerado uma atitude negativa. Ao defender essa postura publicamente, Cardoso assumiu um risco de ser segregado por outras microcelebridades e, assim, ver o seu plano de se tornar o primeiro "blogueiro profissional" do Brasil ser

\footnotetext{
${ }^{34}$ Para um estudo aprofundado acerca do conceito de forasteiros/outsiders, veja ELIAS (2000).
} 
derrubado. Por outro lado, essa atitude contribuiu para a composição e caracterização de sua persona digital, dando-lhe uma figura digital pública, reconhecida na blogosfera.

Cardoso parece conhecer a importância da audiência para a legitimação de sua popularidade e de sua persona pública. Nesse sentido, percebemos que o blogueiro possui um cuidado específico para elevar esses números. No uso dessas táticas, Cardoso atrai um público bastante diversificado. Podemos identificar que, ao usar essas técnicas, Cardoso consegue atrair e manter seu público-alvo ao mesmo tempo em que aumenta o volume de visitantes. Ao reunir grupos com opiniões opostas é natural que seus(suas) seguidores(as) se manifestem e defendam o território em que se acham acolhidos(as), reforçando a posição de destaque da persona digital de Cardoso.

O circuito-Cardoso é composto por referências que dão valor a comportamentos e atitudes desenvolvidas em seu âmbito. Ou seja, a forma de se expressar, e se esta é feita de forma correta ou não, como o(a) comentarista se comporta e como ele(a) reage, assim como o rol de temas considerados polêmicos compõem esse conjunto de valores. Os(as) comentaristas da "corte de Cardoso" valorizam o conhecimento e o bom uso do português como formas de avaliar a inteligência daqueles(as) que ainda não compõem esse grupo. Portanto, para a "corte de Cardoso", a inteligência, sob esta perspectiva, é um dos pré-requisitos para identificar os(as) membros(as) do grupo dentre "paraquedistas" 35 . Por sua vez, estes(as) são segregados(as), recebendo denominações consideradas pejorativas, como: salsinhas, salsinhas de cristo, tards, trolls, por exemplo.

Tudo isso constitui as formas de segregação e de valoração de participações e de performances, especialmente por membros(as) da "corte de Cardoso", de outras microcelebridades e de outras mídias. Por sua vez, dentro do grupo de admiradores(as) de Cardoso existe também uma segregação, tendo em vista que é preciso também construir uma persona para atuar nesses ambientes e, por meio dessas performances, receber atenção pelas colaborações que pode oferecer à "corte de Cardoso". Consequentemente, é preciso encontrar-se familiarizado tanto com as referências constantes a elementos da cultura geek quanto com as piadas e sarcasmos usados pelo grupo. Por sua vez, experiências pessoais são valorizadas

\footnotetext{
${ }^{35}$ Paraquedista é um termo usado por Cardoso e por seus(suas) comentaristas para se referir aos indivíduos que chegam aos blogs da microcelebridade através de sites de busca, como o Google.
} 
como "provas" de que o(a) comentarista tem amplo conhecimento sobre os assuntos abordados, funcionando como um emblema para alcançar status perante os(as) demais comentaristas.

O circuito-Cardoso eleva seu valor simbólico e a sua influência em ambientes digitais ao reunir manifestações legitimadoras de diretrizes e regras coletivas, engendrando uma cultura própria do grupo. Além disso, notamos a existência de um reconhecimento por parte daqueles(as) que atuam fora do circuito-Cardoso, como outras microcelebridades e mídias de massa e digitais. Assim, identificamos que interpretar um post dentro dos parâmetros aceitos por Cardoso e por sua "corte" garante uma performance aceitável no âmbito do circuito-Cardoso. Por sua vez, maior nível de conhecimento do(a) comentarista e objetividade com que esse saber é compartilhado, maiores as chances de ser aceito pela "corte de Cardoso".

Por outro lado, as microcelebridades, reconhecendo essas linguagens e performances, dão legitimidade a Cardoso, ao concordarem e complementarem a performance do blogueiro. Tais atitudes parecem remeter a uma espécie de "experiência" compartilhada mutuamente, tendo em vista que as microcelebridades passariam ou passaram pelas situações apresentadas por Cardoso em seus posts e comentários.

Como microcelebridade, Cardoso sabe do seu poder e da posição de destaque ocupada em seu circuito-blogue. Com isso, adota uma postura de que a sua opinião tem mais valor do que a de qualquer outro(a) participante desse circuito e, por isso, não deve ser contrariada. Além disso, ao compartilhar suas experiências profissionais e de vida, Cardoso reforça a credibilidade de seus posts em uma tentativa de torná-los inquestionáveis. Assim, Cardoso condiciona as performances e interações esperadas por seu público quando define suas posturas, sua performance e as temáticas que abordará nos ambientes digitais em que atua.

Como podemos perceber, a composição de uma persona digital requer um sistema interligado que garanta legitimidade à postura que uma microcelebridade assume em seu circuito-blogue. Nesse sentido, o público, outras microcelebridades e mídias, assim como a própria performance da microcelebridade interferem em sua popularidade e, por conseguinte, no poder simbólico de seu circuito-blogue. Essa pesquisa abre muitas possibilidades, especialmente para que se possa identificar como os atores analisados 
desenvolvem os papéis atribuídos a eles em outros ambientes digitais que, por ventura, estejam ligados ao circuito-Cardoso. Ou seja, a composição de uma persona digital pressupõe pensar em comportamentos e performances que possam ser desempenhados em páginas de sites de redes sociais, em entrevistas a mídias de massa e participação em eventos off-line, no trato com outras microcelebridades e com a parte do público que se encontra mais próxima do blogueiro - "a corte de Cardoso". Nesse sentido, esperamos que, futuramente, possamos observar como essa dinâmica é realizada e como os papéis são adequados às possibilidades e limitações dos diversos contextos propostos.

$\mathrm{O}$ estudo de práticas sociais em ambientes digitais revela aspectos importantes no que concerne à incorporação de novas tecnologias a nossas atividades cotidianas. Um desses aspectos diz respeito à emergência de microcelebridades, como o blogueiro Cardoso, apontando para a existência de valores acordados tacitamente entre os(as) envolvidos(as) em performances e interações realizadas em espaços on-line. Uma vez que uma pessoa desempenhe um papel de destaque, notamos a relevância de pensarmos essas práticas sob a perspectiva da emergência de um discurso aceito dentro de um circuito digital, do qual fazem parte a microcelebridade, seus pares, seus(suas) seguidores(as) e, ainda, seus(suas) críticos(as). Por conta das sucessivas atualizações tecnológicas e da inserção desses dispositivos em nossas vidas, torna-se imprescindível explorar as novas configurações de sociabilidade e poder na esfera digital. 


\section{Referências}

BLUMER, Herbert. Symbolic Interactionism: Perspective and Method. Berkeley: University of California Press, 1998.

BOORSTIN, Daniel J. The Image: A Guide to Pseudo-Events in America. New York: Atheneum, 1980.

BOURDIEU, Pierre. O Poder Simbólico. Rio de Janeiro: Bertrand Brasil, 1989.

BRAGA, Adriana. Personas Materno-Eletrônicas: Feminilidade e Interação no Blog Mothern. Porto Alegre: Editora Sulina, 2008.

. "Complementaridade das mídias: usos sociais da Internet e seus precedentes". In: GT Recepção, Usos e Consumo Midiático. São Paulo: XVII Encontro Compós, 2008. Disponível em: <http://www.compos.org.br/data/biblioteca_398.pdf>. Acesso em 25 ago. 2012.

. "Todo mundo pode ter blog? Práticas de Legitimação na Blogosfera". In: RODRIGUES, Carla (org.). Jornalismo On-line: Modos de Fazer. Porto Alegre: Editora Sulina, 2009.

BRAGA, José Luiz. "Sobre Mediatização como processo interacional de referência". In: GT Comunicação e Sociabilidade. Bauru: XV Encontro Compós, $2006 . \quad$ Disponível em: <http://www.compos.org.br/data/biblioteca_446.pdf>. Acesso em 16 jul. 2012.

CASHMORE, Ellis. Celebrity Culture. New York: Taylor \& Francis e-Library, 2006.

CASTELLS, Manuel. A Galáxia da Internet: Reflexões sobre a Internet, os Negócios e a Sociedade. Rio de Janeiro: Jorge Zahar Editor, 2003.

ELIAS, Norbert. Os Estabelecidos e Outsiders: sociologia das relações de poder a partir de uma comunidade. Rio de Janeiro: Jorge Zahar Editor, 2000. 
FAUSTO NETO, Antônio. "Fragmentos de uma 'analítica' da midiatização". In: Revista MATRIZes, número 2, abril, 2008, pp. 89-105, São Paulo: USP. Disponível em: <http://www.matrizes.usp.br/index.php/matrizes/article/view/88/136>. Acesso em 03 ago. 2012.

FOUCAULT, Michel. A Ordem do Discurso. São Paulo: Edições Loyola, 2010.

GAMSON, Joshua. Claims to Fame: Celebrity in contemporary America. Berkeley: University of California Press, 1994.

GOFFMAN, Erving. A representação do eu na vida cotidiana. Petrópolis: Editora Vozes, 2002.

HOOKWAY, Nicholas. "Entering the Blogosphere: Some Strategies for Using Blogs In Social Research". In: Qualitative Research, vol. 8(1), pp. 91-113, London, UK. Disponível em: < http://qhr.sagepub.com/cgi/reprint/23/3/348>. Acesso em: 18 dez. 2012.

KENDALL, Lori. “'Oh no! I'm a nerd!': Hegemonic Masculinity on an Online Forum". Gender \& Society. Thousand Oaks: Sage Publications, 2000, vol. 14, n. 2, pp. 256-274. Disponível em: < http://gas.sagepub.com/content/14/2/256 >. Acesso em 10 set. 2012.

KONZACK, Lars. "Geek Culture: The $3^{\text {rd }}$ Counter-Culture". In: K. 4.m Miscellaneous. I Fun and Game Conference: Preston, England, 2006. Disponível em: < http://konzack.dk/uploads/geekculture.pdf >. Acesso em 10 set. 2012.

KOZINETS, Robert V. Netnography: Doing Ethnographic Research Online. Sage: London, 2012.

McARTHUR, J.A. "Digital Subculture: A Geek Meaning of Style". Journal of Communication Inquiry. Thousand Oaks: Sage Publications, 2009, vol. 33, n. 1, pp. 58-70. Disponível em: < http://jci.sagepub.com/content/33/1/58 >. Acesso em 25 ago. 2012.

MAINGUENEAU, Dominique. Novas tendências em análise do discurso. Campinas: Editora da Universidade Estadual de Campinas, 1997. 
Análise de Textos de Comunicação. São Paulo:

Cortez, 2004.

MARSHALL, P. David. Celebrity and Power: fame in contemporary culture. Minneapolis: University of Minnesota Press, 2004.

MARTIN-BARBERO, Jesús. Dos meios às Mediações: Comunicação, cultura e hegemonia. Rio de Janeiro: Editora UFRJ, 1997.

MORIN, Edgar. Primeira Parte: A Integração Cultural. In: Cultura de Massa no Século XX. Vol.1. Rio de Janeiro: Forense Universitária, 1977. Cap. 1-7, p. 1385.

Olympio, 1989.

As estrelas: Mito e Sedução no cinema. Rio de Janeiro: José

O'RELLY, Tim. What's Web 2.0? Design patterns and Business models for the next generation of software. Sebastopol: O'Reilly, 2009.

RETTBERG, Jill Walker. Blogging. Polity Press: Cambridge, 2008.

ROJEK, Chris. Celebrity. London: Reaktion Books, 2001.

SÁ, S.; MARCHI, L. "Não basta ser DJ: tem que ser underground! Sobre coletivos e comunidades virtuais de música eletrônica no Brasil'. Revista FAMECOS: mídia, cultura e tecnologia, Brasil, v. 1, n. 26, 2006. Disponivel em:

<http://www.revistas.univerciencia.org/index.php/famecos/article/view/420/347>. Acesso em: 15 mar. 2013.

SIMMEL, Georg. Sociologia. São Paulo: Ática, 1983.

VOSSEN, Gottfried; HAGEMANN, Stephan. Unleashing Web 2.0: from concepts to creativity. Burlington: Elsevier Science, 2007.

WEBER, Max. Economia e Sociedade: Fundamentos da Sociologia Compreensiva, vol. 2. São Paulo: Imprensa Oficial, 2004. 